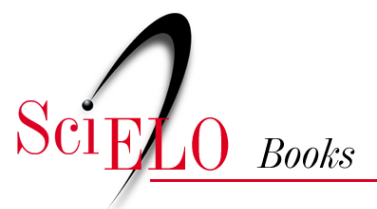

\title{
Fundamentos da educação escolar do Brasil contemporâneo
}

\author{
Júlio César França Lima \\ Lúcia Maria Wanderley Neves \\ (orgs.)
}

\section{SciELO Books / SciELO Livros / SciELO Libros}

LIMA, J.C.F., and NEVES, L.M.W., org. Fundamentos da educação escolar do Brasil contemporâneo [online]. Rio de Janeiro: Editora FIOCRUZ, 2006, 320 p. ISBN: 978-85-7541-612-9. Available from: doi: 10.7476/9788575416129. Also available in ePUB from: http://books.scielo.org/id/j5cv4/epub/lima-9788575416129.epub.

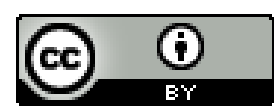

All the contents of this work, except where otherwise noted, is licensed under a Creative Commons Attribution $\underline{4.0 \text { International license. }}$

Todo o conteúdo deste trabalho, exceto quando houver ressalva, é publicado sob a licença Creative Commons Atribição 4.0. 
FUNDAMENTOS

DA EDUCAÇÃO ESCOLAR DO BRASIL CONTEMPORÂNEO 


\section{FUNDAÇÃO OSWALDO CRUZ}

Presidente

Paulo Ernani Gadelha Vieira

Vice-Presidente de Ensino,

Informação e Comunicação

Nísia Trindade Lima

\section{EDITORA FIOCRUZ}

Diretora

Nísia Trindade Lima

Editor Executivo

João Carlos Canossa Mendes

Editores Científicos

Carlos Machado de Freitas

Gilberto Hochman

Conselho Editorial

Claudia Nunes Duarte dos Santos

Jane Russo

Ligia Maria Vieira da Silva

Maria Cecilia de Souza Minayo

Marilia Santini de Oliveira

Moisés Goldbaum

Pedro Paulo Chieffi

Ricardo Lourenço de Oliveira

Ricardo Ventura Santos

Soraya Vargas Côrtes 


\title{
FUNDAMENTOS \\ DA EDUCAÇÃO ESCOLAR DO BRASIL CONTEMPORÂNEO
}

\author{
Júlio César França Lima \\ Lúcia Maria Wanderley Neves \\ Organizadores
}

$3^{\mathrm{a}}$ Reimpressão

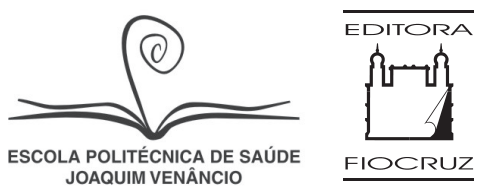


Copyright (C) 2006 dos autores

Todos os direitos desta edição reservados à

FUNDAÇÃO OSWALDO CRUZ / EDITORA E ESCOLA POLITÉCNICA DE SAÚDE

JOAQUIM VENÂNCIO

ISBN: 85-7541-074-1

1 Edição: 2006

$1^{\text {a }}$ Reimpressão: 2007

$2^{\text {a }}$ Reimpressão: 2008

$3^{\text {a }}$ Reimpressão: 2014

Capa, projeto gráfico e editoração eletrônica

Carlota Rios

Revisão e copidesque

Jorge Moutinho e Irene Ernest Dias

Catalogação na fonte

Instituto de Comunicação e Informação Científica e Tecnológica em Saúde/Fiocruz

Biblioteca de Saúde Pública

L732f Lima, Júlio César França (org.)

Fundamentos da educação escolar do Brasil

contemporâneo. / Organizado por Júlio César

França Lima e Lúcia Maria Wanderley Neves.

Rio de Janeiro : Editora Fiocruz/EPSJV, 2006.

320 p., tab., graf.

1.Educação-Brasil. 2.Escolas-Brasil. I.Neves, Lúcia Maria Wanderley (org.). II.Título.

CDD - 20.ed. - 370.981

2014

EDITORA FIOCRUZ

Av. Brasil, 4036 - Térreo - sala 112 - Manguinhos

21040-361 - Rio de Janeiro - RJ

Trels: (21) 3882-9039 e 3882-9041

Telefax: (21) 3882-9006

e mail: editora@fiocruz.br

h tp://www.fiocruz.br/editora 


\section{AUTORES}

\section{Antônio Joaquim Severino}

Filósofo, doutor em filosofia pela Pontifícia Universidade Católica de São Paulo (PUC-SP) e professor titular da Faculdade de Educação da Universidade de São Paulo (USP)

\section{Carlos Nelson Coutinho}

Filósofo, livre-docente pela Universidade Federal do Rio de Janeiro, professor titular da Escola de Serviço Social da Universidade Federal do Rio de Janeiro (ESS/UFRJ)

\section{Gaudêncio Frigotto}

Filósofo e educador, doutor em ciências humanas (educação), professor titular visitante no Programa Interdisciplinar de Pós-Graduação em Políticas Públicas e Formação Humana na Faculdade de Educação da Universidade do Estado do Rio de Janeiro (UERJ) e membro do Comitê Diretivo do Conselho Latino-Americano de Ciências Sociais (Clacso)

\section{Leda Maria Paulani}

Economista, doutora em teoria econômica pelo Instituto de Pesquisas Econômicas da Universidade de São Paulo (IPE/USP), professora da Faculdade de Economia, Administração e Contabilidade da Universidade de São Paulo (FEA/USP) e presidente da Sociedade Brasileira de Economia Política (SEP)

\section{Márcio Pochmann}

Economista, doutor em economia pela Universidade Estadual de Campinas (Unicamp), professor do Instituto de Economia (IE) e pesquisador do Centro de Estudos Sindicais e de Economia do Trabalho (CESIT) DA Universidade Estadual de Campinas.

\section{Miriam Limoeiro Cardoso}

Socióloga, doutora em sociologia pela Universidade de São Paulo (USP), professora (aposentada) do Departamento de Ciências Sociais do Instituto de Filosofia e Ciências Sociais (IFCS) da Universidade Federal do Rio de Janeiro (UFRJ)

\section{Roberto Romano}

Filósofo, doutor em ciências sociais pela Escola de Altos Estudos em Paris, ph.D. em filosofia pela Universidade Estadual de Campinas (Unicamp) e professor titular do Instituto de Filosofia e Ciências Humanas da Universidade Estadual de Campinas (IFCH/Unicamp)

\section{Virgínia Fontes}

Historiadora, doutora em filosofia pela Université de Paris X e calaboradora do Programa de Pós-Graduação em História na Universidade Federal Fluminense (UFF) 


\section{ORGANIZADORES}

\section{Júlio César França Lima}

Enfermeiro, mestre em educação pelo Instituto de Estudos Avançados em Educação da Fundação Getúlio Vargas, coordenador do Laboratório de Trabalho de Educação Profissional em Saúde da Escola Politécnica de Saúde Joaquim Venâncio/Fiocruz e doutorando do Programa de PósGraduação em Políticas Públicas e Formação Humana da Universidade do Estado do Rio de Janeiro (Uerj)

\section{Lúcia Maria Wanderley Neves}

Educadora, doutora em Educação pela Universidade Federal do Rio de Janeiro (UFRJ), professora (aposentada) da Universidade Federal de Pernambuco (UFPE), professora participante do Programa de Pós-Graduação em Educação da Universidade Federal Fluminense (UFF) e pesquisadora da Escola Politécnica de Saúde Joaquim Venâncio/Fiocruz. 


\section{SUMÁRIO}

$\begin{array}{lr}\text { Prefácio } & 9\end{array}$

$\begin{array}{ll}\text { Apresentação } & 11\end{array}$

1. Sobre as Relações Sociais Capitalistas 25

Miriam Limoeiro Cardoso

2. O Projeto Neoliberal para a Sociedade Brasileira:

sua dinâmica e seus impasses

69

Leda Maria Paulani

3. Economia Brasileira Hoje: seus principais problemas

109

Márcio Pochmann

4. Papel Amassado: a perene recusa da soberania ao povo brasileiro 133 Roberto Romano

5. O Estado Brasileiro: gênese, crise, alternativas

Carlos Nelson Coutinho

6. A Sociedade Civil no Brasil Contemporâneo:

lutas sociais e luta teórica na década de 1980

201

Virgínia Fontes

7. Fundamentos Científicos e Técnicos da Relação Trabalho e Educação no Brasil de Hoje

Gaudêncio Frigotto

8. Fundamentos Ético-Políticos da Educação no Brasil de Hoje Antônio Joaquim Severino 


\section{PREFÁCIO}

Este livro foi elaborado especialmente no contexto das comemorações dos vinte anos de existência da Escola Politécnica de Saúde Joaquim Venâncio, da Fundação Oswaldo Cruz (EPSJV/Fiocruz). Seu objetivo é atualizar o debate sobre os princípios e diretrizes da educação escolar brasileira, tendo em vista a formação humana omnilateral e politécnica.

Esse debate se inicia em nosso país nos anos 1980, no bojo da mobilização de educadores brasileiros, partidos políticos e movimentos sociais organizados da área de educação, que procuram ampliar e inscrever conquistas democráticas e, particularmente, uma articulação mais orgânica entre trabalho e educação na Constituição brasileira, então em discussão. É um movimento contemporâneo ao da reforma sanitária, o qual no âmbito da área da saúde se mobiliza em torno da ampliação do conceito de saúde e da construção do Sistema Único de Saúde - e que teve como uma das principais lideranças a Fiocruz.

Em 1987, com apenas dois anos de existência e com o objetivo de formular o projeto educativo do então curso técnico de segundo grau, que iniciou suas atividades no ano seguinte, a EPSJV organizou um importante debate com diversos educadores brasileiros que extrapolaria seus muros, pois naquele momento contribuímos para sistematizar a concepção politécnica de ensino, apresentada mais tarde como proposta de organização do segundo grau, atual ensino médio, no debate constituinte.

Com essa iniciativa, portanto, retomamos esse debate com especialistas de reconhecida notoriedade acadêmica em sua área disciplinar sobre os fun- 
I 0 | Fundamentos da Educação Escolar do Brasil Contemporâneo

damentos filosóficos e sócio-históricos da educação escolar brasileira, buscando assim elaborar princípios e diretrizes para uma proposta do Programa de Pós-Graduação em Educação Profissional em Saúde e, ao mesmo tempo, contribuir para a elaboração de políticas públicas na área de educação e saúde, reafirmando assim o histórico compromisso com a educação da classe trabalhadora brasileira.

André Malhão

diretor da Escola Politécnica de Saúde Joaquim Venâncio 


\section{APRESENTAÇÃo}

Este livro, na forma de coletânea, se inclui em um processo mais amplo de reflexão sobre a educação brasileira contemporânea que vem sendo desencadeado na Escola Politécnica de Saúde Joaquim Venâncio desde as duas últimas décadas do século XX. Constituindo-se em um importante ponto de inflexão nesse processo de sistematização e produção de conhecimentos, tem por objetivo aprofundar algumas constatações iniciais desse debate em curso sobre a sociedade contemporânea e sua relação com a educação, respondendo a algumas demandas urgentes de fundamentação da prática político-pedagógica da escola na atualidade.

A escolha dos capítulos norteou-se por três constatações. A primeira foi a de que as sociedades contemporâneas vêm sofrendo, desde as últimas décadas do século XX, profundas transformações em todas as dimensões da produção da existência humana; a segunda foi a de que essas mudanças se materializam, de modo específico, na sociedade brasileira, devido à maneira como o Brasil vem se inserindo no mundo ao longo da sua história e também devido às relações econômicas, políticas, sociais e culturais que se engendram, também historicamente, em âmbito nacional; e a terceira foi a de que essas profundas mudanças em curso no mundo e no país que redefinem ideais, idéias e práticas sociais repercutem intensamente nos processos de educação política e de educação escolar, levando à redefinição do conteúdo e da forma de estruturação dos sistemas educacionais e de formação técnico-profissional - já que, nas sociedades contemporâneas, a educação vem respondendo, de modo 'específi- 
co', às necessidades de valorização do capital, da conformação ético-política à sociabilidade burguesa e, também, à demanda popular efetiva de acesso ao saber socialmente produzido.

$\mathrm{Na}$ estruturação dos capítulos, influenciaram ainda duas demandas urgentes do debate educacional contemporâneo: a necessidade de identificar a natureza dessas profundas mudanças e a forma como elas interferem na educação brasileira; e, mais especificamente, como essas mudanças interferem na definição de diretrizes e estratégias político-pedagógicas das instituições escolares que têm, na politecnia e na omnilateridade, seus fundamentos essenciais.

As idéias aqui apresentadas, por filósofos e cientistas sociais e por educadores de expressão nacional e internacional, cumprem assim a função de subsidiar as discussões que vêm sendo travadas na EPSJV sobre as diretrizes filosóficas e sócio-históricas contemporâneas da sua prática de ensino e de pesquisa historicamente comprometida com a formação dos trabalhadores brasileiros, nos marcos dos seus vinte anos de existência.

No capítulo 1, intitulado 'Sobre as relações sociais capitalistas', a socióloga Miriam Limoeiro Cardoso procura, na primeira parte, caracterizar a sociedade em que vivemos neste momento. Reflete sobre a dimensão política e a eficácia ideológica da caracterização da sociedade atual como sociedade pósmoderna, estabelecendo relação entre a idéia de modernidade e de pósmodernidade com a idéia de progresso histórico, que naturaliza as relações sociais. Apresenta, em seguida, um painel das contribuições dos diferentes autores que situam as mudanças recentes nas formações sociais como resultado da crise no capitalismo ou do capitalismo. Contrapõe a idéia de capitalismo dependente de Florestan Fernandes à idéia de modernização. Por fim, dialogando com Giovanni Arrighi, Eric Hobsbawm, Immanuel Wallerstein, François Chesnais, Michael Hardt e Antonio Negri, observa que vivemos hoje sob o capital mundializado; o Estado, sem perder sua soberania, adquire novas funções nesta nova era do capitalismo que se inicia, em que se acentua a polarização da riqueza interna a cada país e entre países ricos e pobres.

Na segunda parte, observa que as relações sociais construídas pelo capital se estabelecem, se mantêm e se reforçam por meio de múltiplos mecanismos de dominação, administrados por diferentes tecnologias de poder e inculcados nos diversos aparelhos ideológicos do Estado ou impostos repressivamente. Destaca, como decisivas para o entendimento dessas construções sociais histó- 
ricas, as contribuições de Marx sobre a subsunção do trabalho sob o capital; de Althusser sobre aparelhos ideológicos do estado; e de Foucault sobre tecnologias do poder. Por fim, refletindo sobre as possibilidades de transformação na sociedade em que vivemos, nos brinda com reflexões iluminadoras para a produção de conhecimentos, a definição e a implementação de políticas e o planejamento e execução das atividades na área educacional no Brasil de hoje. Para ela, diante de qualquer tentativa de transformação mais profunda nas sociedades de capitalismo dependente, a luta ideológica - que assume importância decisiva - não prescinde do acesso mais geral possível ao conhecimento crítico, à sua análise e discussão para superar o 'consenso' consentimento/submissão construído ideologicamente pelo poder e que atua como filtro do conhecimento e mesmo das informações e da percepção da realidade.

No capítulo 2, 'O projeto neoliberal para a sociedade brasileira: sua dinâmica e seus impasses', a economista Leda Maria Paulani, discute a história intelectual e a história concreta do neoliberalismo, como condição primeira para se entender a natureza desse projeto em nossa sociedade. A partir da trajetória intelectual do principal representante teórico dessa corrente, Friedrich Hayek, a autora afirma que o neoliberalismo não é uma ciência, mas uma doutrina que busca sedimentar a crença nas virtudes do mercado cujas 'graças' são alcançadas pela interferência mínima do Estado para garantir as regras do jogo capitalista; pelo controle dos gastos estatais e da inflação; pela privatização das empresas estatais; e pela abertura completa da economia. Embora essas idéias já estivessem elaboradas em décadas anteriores, apenas no final dos anos 1970 começam a existir as condições para o domínio e para a aplicação prática de seu receituário de política econômica.

É o que a autora vai demonstrar com as condições concretas que permitiram a assimilação e a produção do discurso que tratou o suposto gigantismo do Estado com sua intervenção na economia, bem como os privilégios que esse tipo de atuação tinha conferido aos trabalhadores ao longo dos 'trinta anos gloriosos', como as causas maiores da crise que se observa a partir de então. Ao mesmo tempo, procura demonstrar como, a partir dos anos 1980, com a mudança do regime de acumulação, o mundo passa a funcionar sob o império da valorização financeira. E faz um alerta: o Estado não se tornou fraco; ao contrário, ele tem de ser extremamente forte, no limite, violento, para conduzir os 'negócios de Estado' da forma mais adequada possível, de modo a preservar e contemplar grupos de interesses específicos. Além disso, observa que as trans- 
formações operadas no setor produtivo estão diretamente ligadas à dominação financeira do processo de acumulação.

Nos países periféricos, o movimento de centralização de capitais que se intensifica de forma inédita nesse período, em vários setores industriais e de serviços, inclusive saúde, e a transnacionalização do capital que o acompanha trazem conseqüências substanciais e pouco alvissareiras para a inserção desses países no sistema-mundo capitalista. De um modo geral, o paradigma digitalmolecular demanda dessas formações sociais grande investimento em ciência e tecnologia, o que está para além das suas forças internas de acumulação. No Brasil, especificamente, acrescenta-se a esse determinante estrutural um importante determinante sociopolítico. Em decorrência do acatamento sem reservas pela elite brasileira das teses neoliberais de internacionalização do padrão de vida e da desterritorialização da riqueza, vendeu-se a idéia de que o país pegaria o bonde da história pela via do comércio exterior. Como o bonde transitou em outra direção, o país transformou-se em plataforma de valorização financeira internacional, bem em linha com o espírito rentista e financista dos dias atuais, com a função de, mais efetivamente a partir dos anos 1990, produzir bens de baixo valor agregado, com a utilização de mais-valia absoluta ou da exploração de mão-de-obra barata.

Finalmente, Paulani procura mostrar na última seção como o país foi sendo preparado para participar do circuito da valorização financeira, principalmente a partir do governo Itamar Franco. Nessa perspectiva, avalia que o desempenho do promissor mercado financeiro foi conquistado, em primeiro lugar, pelo importante papel que cumpriu o discurso neoliberal de um único caminho possível para a superação da crise dos anos 1980 entre a população recém-saída da ditadura militar e o movimento de massas; e em segundo lugar, pelo sentimento difuso de 'emergência econômica' que acompanhou todas as medidas a partir do Plano Real e que, no governo Lula, foi decretado como uma necessidade. Para a autora, a armação desse estado de emergência econômica que presenciamos foi condição de possibilidade para que nossa relação com o centro passasse da dependência tecnológica típica da acumulação industrial à subserviência financeira típica do capitalismo rentista.

De certa forma, a análise efetuada pela autora instiga a perguntar, como faz Gaudêncio Frigotto em outro texto desta coletânea: que tipo de educação escolar e de formação técnico-profissional está presente nas reformas da educação postas em prática pelos governos neoliberais cujas políticas propiciam a 
informalidade do trabalho e a precarização do trabalho formal, ampliando as possibilidades de superexploração da força de trabalho? A educação seria um instrumento poderoso de superação da crise que atravessamos? Quais as conseqüências desse projeto de sociedade e de escolarização para a formação das consciências das futuras gerações?

No capítulo 3, 'Economia brasileira hoje: seus principais problemas', o economista Márcio Pochmann busca destacar a situação geral de estagnação econômica que predomina no Brasil desde 1980. Procura identificar as principais causas que imobilizam o dinamismo da economia nacional, oferecendo para a nossa reflexão educacional novos argumentos. Para o autor, há três fatores que provocam a estagnação da economia nacional: a estabilidade da renda per capita em torno de valores não muito superiores aos da década de 1980; a permanência de baixas taxas de investimento; e a desestruturação do mercado de trabalho. Entretanto, essa situação não pressupõe imutabilidade nas atividades produtivas. Pelo contrário, em sintonia com Leda Paulani, ele observa que está em curso um novo modelo econômico, com baixa taxa de expansão produtiva, forte vinculação à financeirização da riqueza e à revalorização do setor primário exportador.

As principais evidências desse novo modelo, em curso desde 1990, são: 1) a revisão no papel do Estado na economia nacional que, até o momento, não foi suficiente para retomar o desenvolvimento socioeconômico sustentado, nem reverter a tendência de desestruturação do mercado de trabalho; 2) a reinserção externa subordinada, acompanhada pela desfavorável combinação entre câmbio valorizado, juros elevados e ampla abertura comercial e sem políticas industriais ativas, comercial defensiva e social compensatória; 3) a reestruturação das grandes empresas privadas, particularmente com a modernização seletiva e contida de grandes empresas internacionalizadas e concomitante retraimento, fechamento e desnacionalização de outras, além da ênfase na informalização do processo produtivo com os processos de terceirização, redução das hierarquias funcionais, diminuição do núcleo duro de empregados, entre outros fatores; 4) a reformulação do setor público, com os constantes ajustes nas despesas e mais recentemente com o advento do regime de metas de superávit primário nas contas públicas, que passou a impedir o enfrentamento das mazelas nacionais, sobretudo as desigualdades sociais, tornando menos efetiva a política de universalização de direitos sociais, e, por último, 5) a financeirização da riqueza, que é sustentada pelo Estado com base na redução do gasto social, e sua 
contrapartida, a produção do superávit primário, mas que é apropriada privadamente na forma de direitos de propriedade dos títulos que carregam o endividamento público.

A implementação desse novo modelo vem trazendo como conseqüência o aumento da nossa dependência externa, a grave crise do emprego, a desestruturação do mercado de trabalho, o processo de desassalariamento, especialmente com a prevalência de postos de trabalho muito precários. Além disso, o ajuste nas finanças públicas, a geração do superávit fiscal, acabou por subordinar a questão social ao desempenho econômico, e ganharam relevo as medidas de caráter compensatório, deixando em segundo plano o sistema de proteção social universal. Diante disso, configura-se para o autor um quadro social explosivo, com parcela seleta da população ativa se mantendo cada vez menos incorporada aos empregos regulares.

Essas constatações contribuem para que possamos entender o papel político-ideológico da tese da educação para a empregabilidade, difundida nos anos 1990 pelos teóricos das classes hegemônicas, na qual se apregoava a suposta capacidade da educação em criar por si oportunidades de emprego. Ao contrário, o que Pochmann mostra é que, mesmo entre os mais instruídos, cresceu o desemprego, ao mesmo tempo que a elevação da escolaridade da população veio acompanhada da expansão de postos de trabalho de baixos salários, o que leva a reafirmar que um projeto de educação não está descolado de um projeto de sociedade.

O texto do filósofo Roberto Romano, sob o título 'Papel amassado: a perene recusa da soberania ao povo brasileiro', inicia uma série de três capítulos que discutem a gênese e o desenvolvimento das relações de poder no Brasil, em especial as mudanças que estão se processando na estruturação e na dinâmica do Estado e da sociedade civil brasileiros, as quais se constituem em determinantes das profundas alterações na natureza e no ritmo de crescimento do sistema educacional em nosso país.

Segundo ele, no Brasil fingimos seguir a democracia, como forma de poder em que o povo é soberano. Mas, na realidade, ao nosso povo a soberania é recusada em proveito de oligarquias e dos que ocupam os três poderes formais do Estado. Sem que o povo soberano detenha direitos coletivos, é impossível até o presente manter direitos subjetivos.

Para alicerçar seu argumento, analisa as bases do controle da subjetividade no mundo moderno, examinando as teses do poder moderno, do absolutis- 
mo religioso ao laico, com Hobbes e pensadores que o sucederam no século XVIII, destacando em tais doutrinas o afastamento do juízo subjetivo individual na manutenção da ordem do poder público. Ressalta o apelo à soberania popular, aos direitos dos indivíduos e dos grupos, presente nas revoluções inglesa, francesa e norte-americanas, nos séculos XVII e XVIII. Sublinha o retrocesso no que se relaciona com os direitos dos cidadãos, após a derrota dos experimentos democráticos europeus. De acordo com ele, semelhante retrocesso possibilitou a ditadura de Napoleão e, no que diz respeito ao Brasil, a instauração de um poder reacionário, oposto às conquistas revolucionárias, em que o Poder Moderador se configurou no núcleo a partir do qual a democracia foi censurada e reprimida em nosso país.

No entender de Romano, o abuso do poder absoluto vem marcando historicamente o Estado brasileiro, percorrendo os tempos do Império e da República. O permanente estado de rebelião e as necessidades do poder central definem o império como excessivamente preso ao modelo de concentração de poderes, com repercussões na atualidade, com um tipo de federação na qual os estados têm realmente pouca autonomia, sobretudo em matéria fiscal. Em toda a República, as prerrogativas do Poder Moderador foram incorporadas, silenciosamente, à presidência do país, que guarda a pretensão de assumir a preeminência e a intervenção nos demais poderes. Nesse processo de instauração e consolidação do autoritarismo brasileiro, a Igreja, como força espiritual, e as Forças Armadas, como força física, têm papel estratégico.

São dois os problemas que precisam ser enfrentados pelos brasileiros que pretendem instaurar no país um governo do povo: a constituição imperial do nosso federalismo, em que o Poder Central monopoliza todas as prerrogativas do Estado e não as partilha com os demais entes que o constituem; e a acentuação, pela República, da onipotência do chefe do Executivo Central, que não se limita a exercer um poder absoluto no ramo executivo do Estado: ele é também um legislador, e dos mais profícuos.

Essas observações de Romano, além de ajudar no entendimento da natureza excludente do sistema educacional brasileiro e da sua histórica tendência à privatização, contribuem para explicitar as determinações jurídico-políticas das reformas educacionais que vêm sendo implementadas a partir da segunda metade dos anos 1990 e oferecem, ainda, substrato jurídico para a elaboração de propostas educacionais que tenham na soberania popular, nos direitos coletivos, um dos seus pilares fundamentais. 
No capítulo 5, 'O Estado brasileiro: gênese, crise, alternativas', o filósofo Carlos Nelson Coutinho assinala que estamos diante da crise terminal de um tipo de Estado burguês que conhecemos desde a década de 1930, um tipo de Estado que, embora tenha sido responsável em grande parte pelo significativo desenvolvimento econômico ocorrido no Brasil, produziu concomitantemente expressivos déficits de democracia e de justiça social.

Ele identifica algumas características marcantes dessa formação estatal brasileira: a utilização de processos de tipo eminentemente 'não clássicos' durante o enfrentamento de tarefas de transformação social; um forte traço intervencionista e corporativista que perdura, pelo menos, até o governo Geisel; a efetivação da supremacia da classe no poder, por meio da dominação (ou da ditadura) e não da direção político-ideológica (ou de hegemonia); a centralização e o autoritarismo sempre claramente a serviço de interesses privados. Para o autor, a crise desse tipo peculiar de Estado se instaura mais claramente quando o Brasil se torna definitivamente uma sociedade 'ocidental', nos anos finais de 1970, quando o Estado continuou forte, mas passou a contar também com uma sociedade civil forte e articulada, que equilibra e controla a ação do Estado em sentido estrito.

Coutinho observa ainda que, diante dessa crise, surgem duas propostas de redefinição do Estado: uma proposta liberal-corporativa, representativa dos interesses da burguesia, que consiste em desmantelar o pouco que há de público na presente organização estatal; e uma proposta democrática, que representa os interesses das classes subalternas, centrada na reconstrução ou redefinição do espaço público, por meio de mecanismos pelos quais o aprofundamento da democracia nos conduza não apenas a um novo modelo de Estado, mas também a uma sociedade de novo tipo, à sociedade socialista.

Segundo o filósofo, o problema que efetivamente define a conjuntura que se inicia com o fim da ditadura, e que de certo modo persiste até hoje no Brasil, é o de saber de que modo irá se organizar a relação entre Estado e sociedade civil. Para ele, a burguesia tem hoje consciência de que o emprego da ditadura aberta e do compromisso populista como solução para o exercício da dominação tornou-se inviável na atual conjuntura e vem se esforçando por combinar dominação com formas de direção hegemônica, ou seja, por obter um razoável grau de consenso por parte dos governados, na tentativa de hegemonizar pela direita a sociedade civil. Propõe, alternativamente, como tarefa da esquerda, neste momento, combinar a idéia de Estado forte à necessidade 
de torná-lo permeável às pressões que vêm de baixo, ou seja, de uma sociedade civil que se torne cada vez mais hegemonizada pelas classes subalternas.

Os elementos de análise desse autor terminam por coincidir, de certa forma, com as contribuições de Miriam Limoeiro Cardoso, ao destacar a importância do componente ideológico na luta política na atualidade, o que reforça o papel estratégico a ser assumido pela educação política e pela educação escolar das massas trabalhadoras na contemporaneidade, quer para a conservação da ordem capitalista, quer para a sua transformação. Compreender a natureza da pedagogia da hegemonia burguesa brasileira e mundial no atual momento constitui-se, portanto, em tarefa prioritária no balizamento das diretrizes educacionais dos trabalhadores brasileiros na atualidade.

Nessa perspectiva estrutura-se o capítulo 6, da historiadora Virgínia Fontes, 'A sociedade civil no Brasil contemporâneo: lutas sociais e luta teórica na década de 1980'. Com o intuito de rastrear a formação de alguns processos sociais dominantes na atualidade, mais especificamente o processo no qual se forjam e moldam consciências, a autora reflete sobre a história brasileira recente, apresentando elementos significativos para a compreensão do processo de subalternização (educativa e disciplinar) dos setores rebeldes e de conversão de reivindicações sociais urgentes em apassivamento, com base na conceituação gramsciana de sociedade civil.

Segundo a historiadora, a década de 1980 é crucial para a compreensão da sociedade civil no Brasil. Ela apresentava-se como riquíssima arena de luta de classes, ainda que muitos não quisessem mais pensar nesses termos. A luta que a atravessava se dava pela expansão de aparelhos privados de hegemonia de cunhos variados que, em boa parte, guardavam pouca nitidez em relação a sua proximidade com as classes fundamentais - assim como eram ambivalentes nas formas de conceituá-la.

Virgínia Fontes ressalta como determinante nesse processo a expansão das ONGs, que contribuiria para uma diluição importante do significado do engajamento social e para o embaralhamento da percepção da real dimensão da luta que se travava. As ONGs - e, por extensão, boa parcela do Partido dos Trabalhadores - sacralizavam a sociedade civil como momento virtuoso, com o risco de velar a composição de classes em seu interior. Nesse processo peculiar de expansão da sociedade civil, a própria democracia seria também idealizada, como o reino de uma sociedade civil filantrópica e cosmopolita, para a qual todos colaborariam, sem conflitos de classes sociais. O tema da revolução se 
esfumaçava num futuro longínquo e, talvez, desnecessário. Em meio a isso, o projeto de contra-reforma empresarial, fortemente amparado em seus aparelhos privados de hegemonia, se consolidava e se aproveitava dessas contradições para seduzir os setores populares contra seus próprios direitos.

Essas análises da autora, além de darem vida à afirmação de Coutinho de que a sociedade brasileira consolida, nesse período histórico, seu processo de ocidentalização -, oferecem elementos esclarecedores para o entendimento do rápido abandono das demandas educacionais de defesa do ensino público, gratuito e universal, por parte significativa dos organismos sociais representativos dos interesses da classe trabalhadora, e para a aceitação, muito abrangente, da privatização, da focalização e da fragmentação como princípios organizadores da educação escolar brasileira na atualidade.

No capítulo 7, 'Fundamentos científicos e técnicos da relação trabalho e educação no Brasil de hoje', o filósofo e educador Gaudêncio Frigotto, parte do pressuposto de que o trabalho é a categoria ontocriativa da vida humana e de que o conhecimento, a ciência, a técnica, a tecnologia e a própria cultura são mediações produzidas pelo trabalho na relação entre os seres humanos e os meios de vida. A partir dessa idéia central, ele discute duas visões que considera equivocadas sobre a ciência, a técnica e a tecnologia que dominam o debate na sociedade, particularmente o debate educacional. A primeira visão as toma como forças autônomas das relações sociais de produção, de poder e de classe e se expressa de forma apologética nas noções de sociedade pós-industrial e sociedade do conhecimento. O outro viés situa-se na visão de pura negatividade da ciência, da técnica e da tecnologia em face da sua subordinação aos processos de exploração e alienação do trabalhador como forças cada vez mais diretamente produtivas do metabolismo e da reprodução ampliada do capital. Para o autor, as duas visões decorrem de uma análise que oculta o fato de que a atividade humana que produz o conhecimento e o desenvolvimento da técnica e da tecnologia, assim como seus vínculos mediatos ou imediatos com os processos produtivos, se define como (e assume o sentido de) alienação e exploração ou emancipação no âmbito das relações sociais determinadas historicamente. Ou seja: a ciência, a técnica e a tecnologia são alvo de uma disputa de projetos sociais antagônicos da existência humana. Com essa compreensão, ele discute em seguida a dupla face do trabalho: como atividade vital e como alienação sob o capitalismo - a ciência e a técnica como extensão de sentidos e membros humanos e como forças do capital contra o trabalhador, com base nas contri- 
buições de Karl Marx, Antonio Gramsci, George Lukács, István Mészáros e Carlos Paris.

Num segundo momento, busca apreender o papel reservado ao nosso país na divisão internacional do trabalho e como se efetivam, nesse contexto, a formação do trabalho simples e complexo e os desafios e dilemas que enfrentamos atualmente. A análise que realiza da articulação dos elementos culturais, políticos e econômicos, nos marcos de um capitalismo dependente, evidencia que a opção da classe burguesa brasileira, na sua vocação de subalternidade e de associação consentida, é pela cópia da tecnologia, e não pela sua produção.

A partir daí, com base em pesquisas (com Maria Ciavatta e Marise Ramos) e de Lúcia Maria Wanderley Neves, entre outras, Frigotto faz um balanço crítico das reformas e das políticas educacionais, sob o modelo societário neoliberal, procurando explicitar a função social que a classe detentora do capital atribui à escola e à educação técnico-profissional no seu conteúdo, no método e na forma, para a manutenção estrutural de uma sociedade capitalista dependente. Por fim, discute a concepção de educação escolar unitária, politécnica e/ou tecnológica, destacando as questões que impediram o seu avanço concreto na política e na prática educativa, inclusive o refluxo dessa proposta ao longo da década de 1990.

Enfim, o autor nos convida para a necessária e decisiva apropriação do legado do materialismo histórico como referencial capaz de dar à esquerda intelectual e militante os fundamentos para superar dois vieses do marxismo ocidental - o estruturalismo francês e a análise antinômica da realidade histórica -, além de permitir que não se derive para o pessimismo imobilizador ou para o ativismo voluntarista. Ao mesmo tempo, propõe uma agenda contrahegemônica à nova pedagogia da hegemonia do capital, educadora do consenso ao seu projeto societário.

O filósofo Antônio Joaquim Severino, no capítulo final, apresenta o ensaio 'Fundamentos ético-políticos da educação no Brasil de hoje', desenvolvendo-o em três movimentos. No primeiro, de caráter antropológico, explicita a natureza da educação como prática humana, mediada pelo/mediadora do agir histórico dos homens, fundamentando teoricamente a necessária intencionalidade ético-política dessa prática. Para Severino, a prática educativa, como modalidade de trabalho e atividade técnica, é estritamente cultural, posto que se realiza mediante o uso de ferramentas simbólicas. Na condição de prática cultural, serve-se dos recursos simbólicos constituídos pelo próprio 
exercício da subjetividade, em seu sentido mais abrangente, sob duas modalidades mais destacadas: a produção de conceitos e a vivência de valores, que são as referências básicas para a intencionalidade do agir humano, em toda a sua abrangência.

No segundo movimento, de cunho histórico, busca mostrar, inicialmente, como a experiência socioeducacional brasileira marcou-se por diversas subjetivações ideológicas, em especial a ideologia católica, característica do período colonial e imperial; a ideologia liberal, que avança com o desenvolvimento capitalista no Brasil e se consolida após a Segunda Guerra Mundial; e a ideologia tecnocrática, que passa a predominar com a instauração do regime militar em 1964. Em seguida, chama a atenção para os desafios e dilemas da educação brasileira atual no contexto da sociabilidade neoliberal. Para Severino, essa forma atual de expressão histórica do capitalismo, sob o predomínio do capital financeiro, produz um cenário existencial em que as referências ético-políticas perdem sua força na orientação do comportamento das pessoas, trazendo descrédito e desqualificação para a educação. Ao mesmo tempo, a instauração de um quadro de grande injustiça social, sonegando à maioria das pessoas as condições objetivas mínimas de subsistência, interfere profundamente na constituição da subjetividade, no processo de subjetivação, manipulando e desestabilizando valores e critérios.

No terceiro movimento, de perspectiva político-pedagógica, ressalta o compromisso ético-político da educação como mediação da cidadania, dando ênfase à importância que a escola pública ainda tem como espaço público privilegiado para um projeto de educação emancipatória. Severino destaca três objetivos que a educação deve ter no horizonte com o propósito de construir uma outra sociedade a partir de uma nova sociabilidade: desenvolver ao máximo o conhecimento científico e tecnológico em todos os campos e dimensões; desenvolver ao máximo a sensibilidade ética e estética buscando delinear o télos da educação com sensibilidade profunda à condição humana; e desenvolver ao máximo sua racionalidade filosófica numa dupla direção: esclarecer epistemicamente o sentido da existência e afastar o ofuscamento ideológico dos vários discursos. Por fim, observa que educar contra-ideologicamente é utilizar com competência e criticidade as ferramentas do conhecimento e que, por mais ambíguos e frágeis que sejam, esses recursos da subjetividade são instrumentos capazes de explicitar verdades históricas e de significar a realidade objetiva na qual o homem desenvolve a sua história. 
Em suma, de um modo ou de outro, todos os autores desta coletânea, sob diferentes perspectivas, apontam o papel estratégico da escola na sedimentação ou na contestação do projeto hegemônico da sociedade brasileira contemporânea, reafirmando o conhecimento como arma indispensável no enfrentamento e na superação dos vários problemas sociais vivenciados pela maioria dos que vivem do trabalho em nosso país.

A abrangência e a profundidade do tratamento dado às diferentes dimensões que envolvem direta e indiretamente a questão educacional na contemporaneidade brasileira farão desta obra uma referência obrigatória para cientistas sociais, educadores, formuladores de políticas e militantes dos mais diversos organismos sociais que reconheçam na educação uma prática social estratégica na construção de um Brasil justo e soberano. 


\title{
I. Sobre as Relações Sociais Capitalistas
}

\author{
Miriam Limoeiro Cardoso
}

Tout ce qui était solide, bien établi, se volatilise, tout ce qui était sacré se trouve profané, et à la fin les hommes sont forcés de considérer d'un cil détrompé la place qu'ils tiennent dans la vie, et leurs rapports mutuels.

Karl Marx, 1848 (in Marx, 1965:164-165)

The nature of our epoch is multiplicity and indeterminacy. It can only rest on das Gleitende [the moving, the slipping, the sliding], and is aware that what other generations believed to be firm is in fact das Gleitende.

Hugo von Hofmannsthal, 1905 (apud Callinicos, 1989:12)

Il existe un tableau de Klee qui s'intitule "Angelus Novus". Il représente un ange qui semble sur le point de s'éloigner de quelque chose qu'il fixe du regard. Ses yeux sont écarquillés, sa bouche ouverte, ses ailes déployées. C'est à cela que doit ressembler l'Ange de l'Histoire. Son visage est tourné vers le passé. Là où nous apparaît une chaîne d'événements, il ne voit, lui, qu'une seule et unique catastrophe, qui sans cesse amoncelle ruines sur ruines et les précipite à ses pieds. Il voudrait bien s'attarder, réveiller les morts et rassembler ce qui a été démembré. Mais du paradis souffle une tempête qui s'est prise dans ses ailes, si violemment que l'ange ne peut plus les refermer. Cette tempête le pousse irrésistiblement vers l'avenir auquel il tourne le dos, tandis que le monceau de ruines devant lui s'élève jusqu'au ciel. Cette tempête est ce que nous appelons le progrès.

Walter Benjamin, 1940 (in Benjamin, 2000:434) 


\section{Capitalismo, Modernidade, Pós-Modernidade}

O conceito de modernidade expressa a convicção de que o futuro chegou (Habermas, 1987:7). A idéia de modernidade se ligou indissociavelmente à concepção de progresso histórico. Refere-se a uma época que se volta para o futuro e pretende fundar a própria legitimidade na crença relacionada à expectativa de melhoria futura infinita, uma era 'nova', que causa espanto porque transforma de alto a baixo tudo o que havia antes, mas além disso ela mesma promove uma transformação incessante e vertiginosa. Daí sua caracterização como efêmera, fugidia, contingente (Baudelaire), das Gleitende (Hofmannsthal). Mas constrói destruindo.

Curiosamente, essa ordem nova em que 'tudo que é sólido desmancha no ar' pensa tudo o mais em relação a ela, todo o passado como seus antecedentes, e o futuro como sendo apenas o seu futuro. Explica-se a nomenclatura: modernidade e moderno como idênticos a atual, forma presente de algo há muito antecipado; e presente que se prolonga indefinidamente num futuro pensado tão-somente como desdobramento ou desenvolvimento daquilo que é. Assim, a época da historicidade radical naturaliza a história na própria concepção que cria de si mesma. Marx adverte:

fault il bien distinguer les déterminations qui valent pour la production en général, afin que l'unité (...) ne fasse pas oublier la différence essentielle. C'est de cet oubli que découle, par exemple, toute la sagesse des économistes modernes qui prétendent prouver l'éternité et l'harmonie des rapports sociaux existant actuellement. (Marx, 1957:151)

Se a admissão da historicidade dessa sociedade implica a sua constituição num momento histórico dado, implica também a sua transitoriedade - ela não é perene, não é para sempre. 'A' sociedade é somente uma abstração. A concepção de que essa é uma determinada ordem social, histórica, considera-a constituída num dado tempo histórico, por forças sociais, históricas, em ascensão (no caso, burguesas), em luta contra forças sociais, históricas, que sustentavam a formação social anterior. Isso não impede que, em geral, a literatura que trata o capitalismo como sociedade moderna se empenhe em defini-la na 'sua especificidade', diferenciada das sociedades anteriores a ela, mas considerandoas como pré-capitalistas, sob diversas denominações.

A modernidade se afirma não como uma ordem, mas como 'a' ordem. Zygmunt Bauman alerta: 
ordem e caos são gêmeos modernos. Foram concebidos em meio à ruptura e ao colapso do mundo ordenado de modo divino, que não conhecia a necessidade nem o acaso, um mundo que apenas era, sem pensar jamais em como ser. (...) A descoberta de que a ordem não era natural já foi a descoberta da ordem como tal. (Bauman, 1999:12, 14)

Há uma grande clivagem quanto à aproximação pela via teórica - que inclui uma importante dimensão política - do que seja a sociedade atual: considerá-la como sociedade 'moderna' ou como sociedade 'do capital', sociedade capitalista.

A modernidade pode ser concebida como uma proposta de realização do projeto iluminista, implantando uma sociedade racional sob a égide da ciência, que assim ganha ares de senhora da Razão, e que nessa qualidade é chamada a controlar a natureza e também, por que não, o homem. Nesse caso, os dois pólos da clivagem não se afastam; pelo contrário, têm muito em comum. No entanto, depois de tantos genocídios, dos horrores do nazismo e do stalinismo, de Hiroshima e Nagasaki, do atual estado permanente de guerra, impõe-se fazer a crítica, consistente e profunda, da crença na Razão como dominadora do mundo natural e social e como iluminadora por si mesma da consciência dos homens. São exatamente essas as experiências fracassadas que a Teoria Crítica denuncia e que o pós-modernismo também iria denunciar. Em nome da Razão muitas formas de opressão foram forjadas, e assim a modernidade, de expressão de uma força de libertação, mostrou-se uma fonte de subjugação e de repressão.

Bauman coloca bem, o holocausto não é um episódio histórico que deva ser considerado como único, ou porque teria sido especificamente judeu ou especificamente alemão, ou porque teria sido uma erupção específica de forças pré-modernas - bárbaras, irracionais.

A visão nazista de uma sociedade harmoniosa, ordeira, sem desvios, extraía sua legitimidade e atração dessas visões e crenças já firmemente arraigadas na mente do público ao longo do século e meio de história pós-iluminista, repleta de propaganda cientificista e exibição visual da assombrosa potência da tecnologia moderna. (Bauman, 1999:38)

Como estudos críticos do pós-colonialismo podem sugerir, a experiência nazista talvez revele ainda mais fundo o 'espírito do capitalismo' ou a razão do capital, bem distinta da Razão Iluminista. Aimé Césaire diz: 
Oui, il vaudrait la peine de révéler au très distingué, très humaniste, très chrétien bourgeois du XX $\mathrm{XX}^{\mathrm{e}}$ siècle (...) qu'au fond, ce qu'il pardonne pas à Hitler, c'est ne pas l'humiliation de l'homme en soi, c'est le crime contre l'homme blanc, c'est l'humiliation de l'homme blanc, et d'avoir appliqué à l'Europe des procédés colonialistes dont ne révélaient jusqu'ici que les Arabes d'Algerie, les coolies de l'Inde, et les nègres d'Afrique. (Césaire, 1995:12, apud Mezzadra \& Rahola, 2006).

Robin Kelley entende que essa formulação descobre que "the real 'taboo' shuttered by nazi-fascism consists in the very fact of applying directly to white European subjects what was conceivable only in the colonial world" (Kelley, 2002:175, apud Mezzadra \& Rahola, 2006).

O que Max Weber apontou como a racionalização crescente e o desencantamento do mundo - no seu entender características da sociedade capitalista moderna - produziu de fato uma ordem social que é racional para o capital. A racionalidade própria do capitalismo se fundamenta em novas formas de exploração e de dominação e na esperança de que a expansão do capital signifique progresso e melhoria para todos. Walter Benjamin entendia que a tarefa cognitiva mais urgente era desmantelar o mito da história como progresso. Na Dialética do Esclarecimento, Max Horkheimer e Theodor Adorno (1985) se debruçam sobre aquela visão racionalista, idealista e progressista da história e formulam a negação crítica dessa suposta racionalidade prometida pelo Iluminismo e que podia ser experimentada como opressão, conformismo, sofrimento, destruição, nos tempos sombrios da guerra e do fascismo.

Para ser capaz de fazer essa crítica é preciso, antes de mais nada, situar historicamente a razão, buscando encontrar seus vínculos com o poder constituído ou em constituição - dos quais resulta a sua própria formação - e com as classes e os segmentos sociais que impulsionam ou sustentam esse poder.

Dizer de uma determinada sociedade que ela é moderna é considerá-la como a forma social recente. Tal designação supõe uma concepção cronológica de história, concepção que justapõe um 'antigo', anterior, e um 'moderno', atual, com a possibilidade lógica formal de estabelecer momentos intermediários. Como o tempo continua correndo, cabe também especificar um 'mais moderno' em relação ao 'moderno', chamado contemporâneo, por exemplo. Nem sempre, porém, a designação 'contemporâneo' é a mais conveniente, porque nesse tipo de pensamento não há diferença de fundamento entre os diferentes 'momentos' históricos. Como ele opera uma espécie de naturalização da 
história, a singularidade atual é desdobrada em fases ou estágios anteriores de um mesmo processo de desenvolvimento. Neste sentido, o 'contemporâneo' apenas 'atualiza' o 'moderno'. Mas quando a sociedade instalada no Ocidente nos séculos XVIII-XIX foi pensada como sociedade industrial ou moderna, pensamento que foi reforçado no século XX com a chamada 'teoria da modernização', essa caracterização da sociedade como industrial ou moderna pretendia substituir a caracterização histórica dessa mesma sociedade nomeada 'capitalista'. Não se trata apenas de nomes diferentes ou de filigranas de diferenças conceituais entre autores; existe aí uma dimensão profunda que é política, até porque a questão da historicidade diferencial do capitalismo envolve Marx, o(s) marxismo(s), os movimentos socialistas e as sociedades ditas socialistas.

Fredric Jameson fala de uma reinvenção do conceito de modernidade em plena pós-modernidade e supõe que isso faz parte de uma "guerra política discursiva", em que os adversários do livre mercado são classificados por meio da categoria negativa de não-modernos, privados de modernidade (Jameson, 2002:9-10). Encontra nesse tipo de procedimento uma incoerência conceitual e filosófica: são tidos como não-modernos porque ainda são modernistas; é o próprio modernismo que é apreendido como não-moderno. No entanto, a 'modernidade', conforme o novo sentido positivo atribuído ao termo, é tida como 'boa' porque... é pós-moderna!

Embora nem sempre isso seja admitido explicitamente como motivo, para a sociedade capitalista há uma explicação, que pode conter ambivalências ou contradições, mas que além de densidade teórica alcançou enorme densidade política. As teorias sociais pós-modernas consideram o capitalismo como passado, como 'fase' já superada de uma história em processo sempre em busca do novo (aliás, nada mais próprio do espírito da modernidade do que essa incessante busca e incorporação de 'novidade'), o que facilita sem dúvida considerar como também ultrapassados Marx e o(s) marxismo(s). Desse ponto de vista, é mais conveniente nomear esse 'novo' como 'pós' (pós-capitalista, pósmoderno) do que apenas como 'contemporâneo'. Certamente o pós-moderno é muito mais do que uma estratégia teórico-ideológica como essa, porque é marcado profunda e positivamente pela crítica contundente ao Iluminismo, mas certamente também contém um sentido político importante de superação de Marx e do(s) marxismo(s).

Muitos afirmam que já estamos no pós-capitalismo. Sem dúvida, há transformações importantes que ocorrem na década de 1970, acompanhando mu- 
danças tecnológicas significativas e novos padrões organizacionais na produção e na gestão capitalista. Nesse contexto, não faltaram os anunciadores do 'fim' e, conseqüentemente, dos 'pós', exemplarmente representados por Francis Fukuyama e seu 'fim da história' (Cardoso, 1999) ou Daniel Bell e sua 'sociedade pós-industrial'. De fato, essas teorias abrangem as generalizações sociológicas que anunciam com entusiasmo já se ter implantado um tipo de sociedade completamente novo, designado também como sociedade de consumo, sociedade da informação, sociedade do conhecimento etc. Fredric Jameson supõe que essas teorias cumprem uma "missão ideológica", que considera óbvia: "demonstrar, para seu próprio alívio, que a nova formação social em questão não obedece mais às leis do capitalismo clássico" (Jameson, 1991:3). Para este autor, a 'tarefa' ideológica fundamental do conceito de pós-moderno é coordenar novas formas de prática e de hábitos sociais e mentais com as novas formas de produção e organização econômica provocadas pela modificação recente da divisão global do trabalho - ou seja, proclamar que a sociedade já não é mais capitalista. Como o capitalismo não acabou, ${ }^{1}$ sua morte anunciada possui uma dimensão ideológica à qual Jameson se refere como missão ou tarefa a cumprir. Está certo pelo menos nos casos em que produções cujo conteúdo é ideológico são feitas por cientistas que recorrem à autoridade científica para produzir, veicular e fazer circular ideologia. Talvez Jameson generalize em demasia. O que, porém, de modo algum pode servir de argumento para desconsiderar a indicação - que é pertinente e correta - da dimensão ideológica muito eficaz que acompanha aquelas teorias ou faz parte delas.

Por outro lado, também não têm faltado contribuições relevantes analisando as características e as implicações das mudanças recentes como internas ao capitalismo, algumas considerando, aí sim, a existência de crise no capitalismo ou do capitalismo.

\section{Modernização, Capitalismo Dependente}

Para enfrentar o problema de uma nova expansão capitalista e promover na parte pobre e subordinada do mundo mudanças adequadas a essa expansão, surgem as teorias da modernização, que alegam ter validade geral, abrangendo todas as sociedades, em todos os tempos. Essa proposta de mudança é pensada no interior da concepção norte-americana de Guerra Fria, que as próprias teorias da modernização ajudaram a consolidar. 
By defining a singular path of progressive change, the concept of modernization simplified the complicated world-historical problems of decolonization and industrialization, helping to guide American economic aid and military intervention in post-colonial regions. (Gilman, 2003:3) ${ }^{2}$

Do modo como a teoria da modernização organiza o mundo, as sociedades em geral são distribuídas dentro de uma mesma escala, na qual é possível distinguir um padrão ou estágio 'primitivo'3 ou 'tradicional' e um outro 'moderno', com variados ou variáveis estados intermediários, cada um dos quais identificado por possuir diferencialmente atributos que são definidos pela própria teoria. A modernização é apresentada como o processo de passagem de um padrão a outro, passagem no entanto não explicada pela teoria.

A modernização se refere à mudança apenas numa certa direção, a direção desejada, até porque "there were no controversial choices to make, since the goal was already given” (Therborn, 2001:57). Mesclando profundamente teoria e ideologia, a modernização elabora, justifica e ela mesma legitima a própria elaboração. Latham (2000:60) a qualifica como uma combinação de visão missionária e controle imperial. ${ }^{4}$

As teorias da modernização são produzidas precisamente no momento histórico em que uma nova hegemonia está se constituindo no desenvolvimento do capitalismo. Portanto, são muito convenientes teórica e politicamente. A partir da Segunda Guerra Mundial e no imediato pós-guerra, o capitalismo começava uma nova expansão, e a economia dos Estados Unidos, fortalecida durante a guerra, colocava em pauta a necessidade de expandir os mercados e aumentar um certo tipo de produção na Ásia, na América Latina e na África (Cardoso, 2005b). É nesse exato momento que as teorias da modernização e do desenvolvimento, conjugadas, são oferecidas como fundamentação das políticas desenvolvimentistas, as quais são apresentadas como garantia para a nova expansão capitalista voltada para o Terceiro Mundo e, no mesmo movimento, como barragem contra uma temida expansão comunista.

No Brasil, a modernização tem sido a perspectiva dominante no cenário político, pelo menos a partir de Juscelino Kubitschek, com as exceções dos governos Jânio Quadros e João Goulart. A ditadura militar instalada em 1964 retomou e radicalizou a política de caráter modernizador que já havia caracterizado o governo JK e desde então essa perspectiva vem orientando, sem qualquer interrupção, a ação do governo central no Brasil, ela própria se adaptando aos novos formatos que a modernização tem assumido. Na política brasileira, 
Juscelino Kubitschek é exemplar quanto à modernização desenvolvimentista e Fernando Henrique Cardoso quanto à modernização neoliberal (Cardoso, 2005c).

Muitos consideram a modernização como uma perspectiva datada, por seu alcance limitado a um período que já estaria encerrado. No entanto, o que se tem chamado de globalização consiste na retomada da 'teorização' da modernização, adaptando-a às formas atuais da expansão capitalista. "Indeed it [modernization theory] created the rationale for economic aid. The debate is still far from dead. Modernization theory resurfaces in current debates about modernity and post-modernity and in the neo-liberal agenda" (Dickson, 1997:36). Fala-se mesmo em teoria da modernização neoliberal (Kieley, 1995). A questão em torno da modernização continua atual e relevante.

A modernização tem recebido críticas severas, mas tem funcionado de fato como uma ideologia muito eficaz, como que impermeável à crítica. Entranhou-se nas concepções usuais, aceitas de maneira geral. No Brasil, desde JK tornou-se senso comum querer ser 'moderno', vale dizer, ser 'desenvolvido', equiparar-se ao 'Primeiro Mundo'. A ideologia da modernização, de uma forma ou de outra - seja com o desenvolvimentismo, seja com o neoliberalismo -, continua definindo em nossa sociedade o 'moderno' como a sociedade capitalista mais avançada, definição pautada na sociedade norte-americana e seu modo de vida. A enorme eficácia dessa ideologia se demonstra na sua capacidade de colocar o 'desenvolvimento' ou a 'modernização' como o nosso objetivo maior, que - apesar dos impasses e da comprovação empírica das colossais dívidas externas, resultados concretos das políticas desenvolvimentistas, e do fosso que só faz agravar-se entre os países como o nosso e o chamado Primeiro Mundo - se mantém na ideologia política e econômica como alcançável no futuro, sempre adiado.

Essa dominância da modernização não se exerceu unicamente como ideologia, no mundo social, no econômico e no político. Ela alcançou em cheio as ciências sociais e o mundo acadêmico, especialmente nas décadas de 1950 e 1960, oferecendo suporte ‘teórico’ para as políticas desenvolvimentistas. Tanto no plano das teorias quanto no das políticas, o desenvolvimento é sempre tratado em termos nacionais, referido em cada caso a um determinado Estadonação. O desenvolvimento é sempre desenvolvimento nacional. A teoria da modernização chega a prever a necessidade de uma ideologia para dar sustentação e legitimidade social à promoção acelerada da modernização ou desenvolvimento. Talcott Parsons, o maior expoente teórico da modernização, diz: “in 
this discussion, I have broadly located the center of developmental initiative in a bureaucratic political structure, and outlined an ideological setting within which development is likely to take place”. Afirma que há uma determinada direção desejada, "the impetus to economic development under non-Communist auspices", o que depende de agenciamento a ser conduzido na esfera política nacional local. Parsons define a ideologia que convém para dar sustentação a esse agenciamento: "the nationalistic-developmental complex of ideology" (Parsons, 1960:124, 125, 126). Não descreve um processo histórico real, propõe uma direção política a ser construída nas regiões que a política do capital pretende 'modernizar'.

Rapidamente a teoria da modernização tornou-se dominante nas ciências sociais na academia, ao mesmo tempo que o desenvolvimento se tornava ideologia dominante em países como o Brasil (Cardoso, 1972). É nesse contexto que Florestan Fernandes se afasta dessas duas influências e as submete à crítica que as supera teoricamente, produzindo assim um importante contraponto para alcançar a especificidade dos países que a teoria da modernização designava como 'tradicionais' e que a teoria do desenvolvimento passou a chamar de 'subdesenvolvidos'. Esse contraponto provinha de outra formação teórica e questionou a fundo aquelas 'teorias'. Refiro-me à produção do conceito e da teorização do capitalismo dependente por Florestan Fernandes.

Para pensar 'o Brasil' e explicá-lo, Florestan entende que é necessário alcançar as relações que o determinam estrutural e dinamicamente. Nessa busca, adota como critério metodológico que "o importante e decisivo não está no passado, remoto ou recente, mas nas forças em confronto histórico, em luta pelo controle do Estado e do alcance da mudança social" (Fernandes, 1974:209210). O passado colonial é importante, mas não é o passado que explica o presente; é preciso situar o objeto no conjunto das forças sociais em confronto na situação atual. Florestan logo compreende que apenas em parte essas forças sociais se encontram dentro dos limites do Estado-nação. Preocupa-o por que, com a Independência, não nos tornamos independentes de fato. A questão não se resolve no plano político-jurídico. A sociedade nacional não se constitui como uma totalidade autodefinível. É necessário colocá-la como parte que é do capitalismo em expansão, para alcançar a sua especificidade nos processos de acumulação do capital que caracterizam essa expansão num momento determinado.

$\mathrm{Na}$ formulação de Florestan Fernandes, a expansão do capitalismo monopolista cria capitalismo dependente. ${ }^{5} \mathrm{O}$ Brasil se inscreve nessa expansão 
da seguinte forma: o país é uma particularidade que pertence à generalidade capitalismo por meio da especificidade capitalismo dependente. Florestan descobre que a 'integração' de países do mesmo tipo que o Brasil à expansão capitalista é propriamente uma forma, particular e específica, que o desenvolvimento capitalista assume nas economias dependentes. Formula então o capitalismo dependente como conceito. Capitalismo dependente é uma forma que o desenvolvimento capitalista assume na sua fase monopolista. Numa das formulações mais abrangentes do conceito no plano econômico, Florestan o define como

uma economia de mercado capitalista constituída para operar, estrutural e dinamicamente: como uma entidade especializada, ao nível da integração do mercado capitalista mundial; como uma entidade subsidiária e dependente, ao nível das aplicações reprodutivas do excedente econômico das sociedades desenvolvidas; e como uma entidade tributária, ao nível do ciclo de apropriação capitalista internacional, no qual ela aparece como uma fonte de incrementação ou de multiplicação do excedente econômico das economias capitalistas hegemônicas. (Fernandes, 1968:36-37)

O conceito de capitalismo dependente inclui necessariamente as classes sociais. Segundo Florestan, a explicação sociológica do subdesenvolvimento deve

ser procurada no mesmo fator que explica, sociologicamente, o desenvolvimento econômico sob o regime de produção capitalista: como as classes se organizam e cooperam ou lutam entre si para preservar, fortalecer e aperfeiçoar, ou extinguir, aquele regime social de produção econômica. (Fernandes, 1968:27-28)

Portanto, o capitalismo dependente não é atribuído exclusivamente a uma dominação externa. As burguesias locais são parceiras das burguesias hegemônicas. Como parceiras menores e subordinadas, mas parceiras, as chamadas burguesias 'nacionais' desempenham papel decisivo na articulação do capitalismo dependente com os centros mais dinâmicos da expansão capitalista. Desse modo, com a participação das classes sociais na análise, o conceito de capitalismo dependente permite produzir o "desmascaramento simultâneo" da dominação imperialista e das burguesias "nacionais" (Fernandes, 1995:143). Tendo compreendido a articulação das burguesias locais com a burguesia internacional, consegue-se entender a exacerbação da exploração capitalista do trabalho no capitalismo dependente. Como frações burguesas dependentes, tendo em vista 
a necessidade de partilha entre as burguesias parceiras, as burguesias locais criam expropriação e exploração excedentes.

A importância de uma concepção como essa não se esgota enquanto análise, mas traz conseqüências políticas da mais alta relevância. Não se trata de relações 'entre nações' nem propriamente de relações entre burguesias hegemônicas e burguesias dependentes. Trata-se de relações de dominação que se conjugam: dominação externa $e$ dominação interna. A dominação externa é realizada por meio da dominação interna, e esta se exerce não sobre um setor ou uma fração da burguesia, mas sobre o trabalho e a massa da população. Há, portanto, um padrão de acumulação de capital que é típico da relação de parceria desigual das burguesias envolvidas, que Florestan designa como "sobreapropriação repartida do excedente econômico" (Fernandes, 1973:57).

Desenvolver-se de modo desigual é próprio do capitalismo. A expansão do capital se faz criando desigualdades. O capitalismo opera como um sistema que desenvolve e integra ou exclui de maneira desigual as economias mais dinâmicas e as economias capitalistas dependentes. $\mathrm{O}$ capitalismo dependente, portanto, é uma forma subordinada da expansão 'normal' do capitalismo monopolista, é "a forma periférica e dependente do capitalismo monopolista, o que associa inexorável e inextricavelmente as formas 'nacionais' e 'estrangeiras' do capital financeiro" (Fernandes, 1985:50). Para Florestan, “a dominação econômica, sociocultural e política inerente ao imperialismo torna-se uma dominação total, que opera a partir de dentro dos países neocoloniais e dependentes e, ao mesmo tempo, afeta em profundidade todos os aspectos de sua vida econômica, sociocultural e política" (Fernandes, 1995:139).

Florestan estabelece uma relação entre a forma do campo econômico e a do campo político no capitalismo dependente. À superexploração e à superexpropriação econômica corresponde uma drástica redução da democracia. Na sociedade ainda mais desigual do capitalismo dependente, a democracia se torna uma democracia restrita, apenas uma democracia de iguais. Desse modo, o capitalismo dependente é caracterizado como sobreexploração/ sobreexpropriação e como autocracia.

No capitalismo subordinado ou dependente, a desigualdade que é própria do desenvolvimento capitalista se torna extremada: uma minoria social dominante retém para si todos os privilégios como se fossem direitos e exclui de todos os direitos a grande maioria da sociedade, como se isso fosse natural. 
Florestan caracteriza a dominação da burguesia local no capitalismo dependente como tirânica. Esclarece que não se trata

apenas de defender a 'liberdade' e a 'democracia'. Porém, de pôr em evidência que a sociedade de classes engendrada pelo capitalismo na periferia é incompatível com a universalidade dos direitos humanos: ela desemboca em uma democracia restrita e em um Estado autocrático-burguês, pelos quais a transformação capitalista se completa apenas em benefício de uma reduzida minoria privilegiada e dos interesses estrangeiros com os quais ela se articula institucionalmente. (Fernandes, 1980:77)

No capitalismo dependente, a autocracia é uma característica permanente da forma de dominação que as burguesias dependentes adotam, não é uma exceção. Com a caracterização do político como autocracia, completa-se o que Florestan Fernandes compreende por capitalismo selvagem.

A análise da condição capitalista dependente do Brasil e da América Latina mostra as dificuldades que essa condição apresenta para a sua transformação:

Não cabe ao sociólogo negar alternativas à transformação das sociedades humanas. Elas existem, o difícil seria prognosticar qual delas poderá ocorrer. Na América Latina, ao que parece, as burguesias perderam a oportunidade histórica de se tornarem agentes da transformação concomitante das formas econômicas, sociais e políticas inerentes ao capitalismo. Por isso, o avanço nessa direção tende a fazer-se, ainda em nossos dias, como processo de modernização, sob o impacto da incorporação dos sistemas de produção e dos mercados latino-americanos às grandes organizações da economia mundial. As burguesias de hoje por vezes imitam os grandes proprietários rurais do século XIX. Apegam-se ao subterfúgio do desenvolvimentismo como aqueles apelaram para o liberalismo: para disfarçar uma posição heteronômica e secundária. $\mathrm{O}$ desenvolvimentismo encobre, assim, sua submissão a influências externas, que se supõem incontornáveis e imbatíveis. A mesma coisa acontece com o nacionalismo exacerbado. Quando ele reponta, no seio dessas burguesias, quase sempre oculta algo pior que o fracasso histórico e a frustração econômica: envolve uma busca de esteios para deter a torrente histórica e preservar o próprio capitalismo dependente, e segundo valores provincianos. (Fernandes, 1968:101)

A transformação é objetivamente possível, mas é travada, especialmente em termos ideológicos, pelos poderosos interesses do capitalismo dependente e do desenvolvimento capitalista dependente. 


\section{A Sociedade em que Vivemos sob o Capital MUNDIALIZADO}

\section{A CRISE}

Hobsbawm, para quem o século XX foi breve (de 1914 a 1991), afirma não haver dúvida de que dos últimos anos da década de 1980 aos primeiros da década de 1990 se define um período que marca o encerramento de uma era e o começo de uma nova era no capitalismo. O século XX se iniciou por uma 'era de catástrofe' (definida pelas duas grandes guerras mundiais), seguida por uma 'era de ouro' (compreendendo os 25 ou trinta anos de extraordinário crescimento econômico e transformação social), e desde os anos 1970 se instalou uma 'era de decomposição, incerteza e crise', que Hobsbawm designa como uma "melancolia fin-de-siècle" (Hobsbawm, 1997:15). A crise é econômica, política, social e moral (Hobsbawm, 1997:20), e o clima é de insegurança e de ressentimento (Hobsbawm, 1997:397-398).

Para Wallerstein, no entanto, o que se descobriu recentemente como 'globalização', que estaria mudando completamente o nosso mundo, "is nothing but the basic operating principle of the capitalist world-economy" (Wallerstein, 2001:viii). Com sua perspectiva do sistema-mundo, Wallerstein afirma que a cadeia transnacional de mercadorias é extensiva desde a própria constituição do capitalismo como sistema e se tornou global desde a segunda metade do século XIX. Entende que o sistema não sofreu transformações profundas ou estruturais ao longo do século XX:

To be sure, the improvement in technology has made it possible to transport more and different kinds of items across great distances, but I contend that there has not been any fundamental change in the twentieth century, and that none is likely to occur because of the so-called information revolution. (Wallerstein, 1999:59)

Assim, com a globalização ou com a revolução informacional, o capitalismo não acabou nem sofreu transformação fundamental na sua estrutura.

Contrariamente ao discurso ultraliberal - que apresenta a globalização como resultado 'inevitável' do jogo livre das leis do mercado, sob uma concorrência globalizada e liberada de todos os 'entraves' das regulamentações públicas, o que favoreceria afinal o 'consumidor', que agora teria acesso livre ao 
circuito também livre de mercadorias em âmbito mundial -, Chesnais (1995) observa que o conteúdo efetivo da globalização não se refere à mundialização das trocas, mas à mundialização das operações do capital, tanto na sua forma industrial quanto na sua forma financeira. Identifica no contexto macroeconômico mundial uma nova fase no processo de internacionalização, sob um novo regime mundial de acumulação. Estuda as "mudanças estruturais maiores da economia capitalista mundial das duas últimas décadas" e procura compreendê-las "com a ajuda da noção de regime de acumulação com dominância financeira" (Chesnais, 2003:45).

Arrighi, apoiado metodologicamente na perspectiva da 'longa duração' (Braudel), diferentemente de Hobsbawm fala do 'longo século XX', entendendo que a partir da década de 1970 tem início uma modificação fundamental do capitalismo, que é preciso analisar nos termos dos processos mundiais de acumulação de capital. Diz, porém, que essas transformações em curso apenas aparentemente são revolucionárias: nos anos 1970 e 1980 se verifica uma tendência predominante de acumulação de capital em escala mundial que é crescentemente financeira, mas "não parece ser uma tendência nada 'revolucionária” (Arrighi, 1996:309). Recorrendo a Braudel, entende que

o capital financeiro não é uma etapa especial do capitalismo mundial, muito menos seu estágio mais recente e avançado. Ao contrário, é um fenômeno recorrente (...). Ao longo de toda a era capitalista, as expansões financeiras assinalaram a transição de um regime de acumulação em escala mundial para outro. Elas são aspectos integrantes da destruição recorrente de 'antigos' regimes e da criação simultânea de 'novos'. (Arrighi, 1996:ix-x)

Sob essa perspectiva, Arrighi supõe que a atual expansão financeira corresponde ao momento conclusivo de um determinado estágio de desenvolvimento do sistema capitalista mundial.

Em análises realizadas em outro registro, Hardt e Negri sustentam que na segunda metade do século XX ocorreu uma profunda transformação pela qual se configura uma nova realidade. Falam da "globalização irresistível e irreversível de trocas econômicas e culturais" (Hardt \& Negri, 2005a:11). Dizem que,

juntamente com o mercado global e com circuitos globais de produção, surgiu uma ordem global, uma nova lógica e estrutura de comando - em resumo, uma nova forma de supremacia. O Império é a substância 
política que, de fato, regula essas permutas globais, o poder supremo que governa o mundo. (Hardt \& Negri, 2005a:11)

Para os dois autores, essa é uma realidade efetivamente nova, distinta do imperialismo.

A transição para o Império surge do crepúsculo da soberania moderna. Em contraste com o imperialismo, o Império não estabelece um centro territorial de poder, nem se baseia em fronteiras ou barreiras fixas. É um aparelho de descentralização e desterritorialização do geral que incorpora gradualmente o mundo inteiro dentro de suas fronteiras abertas e em expansão. O Império administra entidades híbridas, hierarquias flexíveis e permutas plurais por meio de estruturas de comando reguladoras. As distintas cores nacionais do mapa imperialista do mundo se uniram e mesclaram num arco-íris imperial global. (Hardt e Negri, 2005a:12-13)

Identificam nessa transformação "uma mudança no modo capitalista de produção” (Hardt \& Negri, 2005a:13). Numa reflexão sobre metodologia, propõem a necessidade de rever a Introducão de 1857, de Marx, para permitir sua aplicação "na transformação". Afirmam: "Hoje precisamos de uma nova Einleitung, porque a essência do capitalismo (sua maturidade e sua estabilização global) está radicalmente modificada" (Negri, 2003:241). Para Hardt e Negri, essa transformação caracteriza os estilos históricos da pós-modernidade.

\section{O ESTADO}

Os estudos sobre o desenvolvimento capitalista atual se detêm sobre a questão do Estado, acentuando suas novas funções ou o deslocamento da soberania. Segundo Wallerstein, hoje há sinais de crise no capitalismo no âmbito da soberania do Estado nacional. A peculiaridade a observar é que estados são soberanos dentro de um sistema interestatal. A soberania reclamada pelos estados desde o século XVI não diz respeito propriamente ao Estado como tal, mas ao sistema interestatal. É uma pretensão dupla, porque voltada para dentro e para fora do Estado. A soberania do Estado 'para dentro', no limite do seu território, autoriza esse Estado a definir e aplicar as políticas e as leis julgadas apropriadas ou necessárias, tendo garantido o direito de vê-las obedecidas por todos os que fazem parte desse Estado. A soberania do Estado 'para fora' garante a esse Estado a não-interferência de outro Estado dentro dos limites do Estado em questão. Neste sentido, a soberania envolve o reconhecimento mútuo dessas pretensões de cada Estado no sistema interestatal. “That is, sovereignty 
in the modern world is a reciprocal concept" (Wallerstein, 1999:60). A soberania dos Estados dentro do sistema interestatal "is a fundamental pillar of the capitalist world-economy. If it falls, or seriously declines, capitalism is untenable as a system" (Wallerstein, 1999:74). Daí por que o declínio que é possível observar hoje na soberania dos Estados pode ser tomado como um sinal importante da crise aguda por que passa atualmente o capitalismo como um sistema histórico.

Wallerstein argumenta, porém, que os capitalistas dependem da intervenção dos Estados de tantas maneiras que "any true weakening of state authority is disastrous" (Wallerstein, 1999:73). Daí por que

the essential dilemma of capitalists, singly and as a class, is whether to take full short-run advantage of the weakening of the states, or to try short-run repair to restore the legitimacy of the state structures, or to spend their energy trying to construct an alternative system. Behind the rhetoric, intelligent defenders of the status quo are aware of this critical situation. (Wallerstein, 1999:74)

Arrighi aponta uma fusão singular do Estado com o capital nessa fase. Cita Max Weber ao mostrar como o desenvolvimento do capitalismo moderno dependeu do Estado nacional, de tal modo que o capitalismo persistirá enquanto o Estado nacional não der lugar a um império mundial. ${ }^{6}$ Para Arrighi (1996:343), está havendo um "definhamento do moderno sistema de Estados territoriais como locus primário do poder mundial”, o que estaria levando a uma busca de formas interestatais de governo mundial.

Os Estados nacionais já não são mais soberanos, segundo Hardt e Negri. O Estado-nação perdeu algumas de suas prerrogativas fundamentais e vem redefinindo suas funções, concentradas sobretudo nas questões de segurança e de ordem pública interna (Negri, 2003:38). O comando efetivo já não se encontra mais no nível do Estado-nação. A hipótese básica é que "a soberania tomou nova forma, composta de uma série de organismos nacionais e supranacionais, unidos por uma lógica ou regra única" (Hardt \& Negri, 2005a:12). A soberania imperial não se localiza em nenhum Estado-nação. "Os Estados Unidos não são, e nenhum outro Estado-nação poderia ser, o centro de um novo projeto imperialista” (Hardt \& Negri, 2005a:13-14). Neste sentido, é contraproducente que a luta contra o Império tenha como alvo os EUA, sob a suposição de que o comando do Império estaria nas mãos do governo norteamericano. Nenhum país, nem os EUA nem qualquer outro, irá ocupar a posição de comando imperial de forma semelhante à que os Estados-nação 
então hegemônicos ocuparam no imperialismo. Para Hardt e Negri (2005a:14), "O imperialismo acabou". "A soberania imperial se encontra em um 'nãolugar"” (Negri, 2003:12).

As grandes corporações não operam mais como no imperialismo, elas "estruturam e articulam territórios e populações", criando uma nova geografia mundial, "uma nova estruturação biopolítica do mundo" (Hardt \& Negri, 2005a:50-51). Essa nova estruturação global, que constitui um mundo sulcado, cujas "estrias" se apresentam "cada vez mais móveis e dinâmicas" (Negri, 2003:13), requer uma regulamentação que substitua não apenas de fato, mas também de direito, a regulamentação estatal, que atualmente já está de várias maneiras subordinada a decisões, determinações e controles supranacionais. Hardt e Negri sustentam que não há globalização sem regulamentação e, com isso, se dedicam à análise jurídico-política que se aplique ao nível imperial, em substituição ao direito internacional.

Arrighi, no entanto, concentra a atenção em como a mundialização do capital reflete mudanças qualitativas nas relações de forças políticas entre o capital e o Estado e entre o capital e o trabalho. Especialmente sob o impacto das novas tecnologias aplicadas à produção industrial, o capital reorganiza seu processo de internacionalização e modifica suas relações com o trabalho, sobretudo no setor industrial, fazendo desregulamentar antigos 'direitos' trabalhistas e adotando crescentemente o que chama de 'flexibilização' dos contratos salariais, que estabelecem na verdade novas relações de precarização do emprego. Num quadro de desemprego estrutural, essa precarização enfraquece ainda mais o trabalho frente ao capital.

Chesnais avança a compreensão desse processo. Enfatiza a importância do Estado para o estabelecimento do novo regime mundial de acumulação, já que são os Estados que, se não formulam, implementam as políticas de liberalização, desregulamentação e privatização que esse regime de acumulação mundial requer. Esse regime se caracteriza pelo oligopólio mundial, fruto da progressão quantitativa e qualitativa dos movimentos conjugados de centralização e de concentração do capital industrial. Chesnais reconhece uma nova configuração das multinacionais, constituídas por grupos financeiros com dominância industrial (que já não são mais propriamente 'empresas' ou 'firmas'), com alto grau de financeirização e tendência para fortalecer o capital rentista. 


\section{A POLARIZAÇÃO}

Hobsbawm se detém no contraponto entre o que chama de "teologia" ultraliberal do livre-mercado e o desemprego estrutural, a agudização da pobreza e da miséria (com um aumento impressionante da desigualdade econômica e social e o reaparecimento de miseráveis sem-teto) e o crescimento vertiginoso da dívida, seguido da clara decisão por parte da economia mundial capitalista de "cancelar uma grande parte do Terceiro Mundo". O que o leva a concluir que "o principal efeito das Décadas de Crise foi assim ampliar o fosso entre países ricos e pobres” (Hobsbawm, 1997:413).

Arrighi identifica uma tendência recorrente nos processos de financeirização (por exemplo, na Espanha na primeira década de 1600, na Florença renascentista, nos Estados Unidos no final do século XX). Cada um desses processos tem acentuado de forma extrema o contraste entre ricos e pobres num mesmo país. Atualmente, esses efeitos polarizadores da financeirização alcançam escala mundial, acompanhando a reorganização da economia capitalista, que tenta recuperar-se das suas crises em bases sempre maiores, ampliando, portanto, sua esfera de ação em escala mundial, acentuando ainda mais a polarização também nesse nível.

Também Chesnais vincula a mundialização do capital à polarização da riqueza, primeiramente interna a cada país, em seguida internacional, cavando um fosso brutal entre "os países localizados no coração do oligopólio mundial e aqueles que ficam na periferia deste" (Chesnais, 1995:15), os quais passam a ser objetos de integração seletiva e, no caso de um grande número de países pobres, de desconexão (que os transforma em 'zonas de pobreza'), em função das escolhas para a localização dos investimentos globais. O regime de acumulação com dominância financeira “é uma 'produção' dos países capitalistas avançados, com os Estados Unidos e o Reino Unido à frente” (Chesnais, 2003:52). Para Chesnais,

este regime é indissociável das derrotas sofridas pela classe operária ocidental, bem como da restauração capitalista na ex-União Soviética e nas pretensas 'democracias populares'. Ele não é mundializado no sentido em que englobaria o conjunto da economia mundial numa totalidade sistêmica. Inversamente, ele é efetivamente mundializado no sentido em que seu funcionamento exige, a ponto de ser consubstancial à sua existência, um grau bastante elevado de liberalização e de desregulamenta- 
ção não apenas da finança, mas também do investimento externo direto

(...) e das trocas comerciais. (Chesnais, 2003:52)

Sob esse regime de acumulação, as medidas de liberalização e desregulamentação devem ser impostas em todos os lugares, mundo afora. A mundialização que resulta do regime de acumulação com dominância financeira "possui, de modo evidente, a função de garantir a apropriação, em condições tão regulares e seguras quanto possível, das rendas financeiras - juros e dividendos - numa escala mundial" (Chesnais, 2003:53).

II

Une critique (...) consiste à voir sur quels types d'évidences, de familiarités, de modes de pensée acquis et non réfléchis reposent les pratiques que l'on accepte. (...) La critique consiste à débusquer cette pensée et à essayer de la changer. (...) Dans ces conditions, la critique (et la critique radicale) est absolument indispensable pour toute transformation. Car une transformation qui resterait dans le même mode de pensée, une transformation qui ne serait qu'une certaine manière de mieux ajuster la même pensée à la réalité des choses ne serait qu'une transformation superficielle.

Michel Foucault, 1981 (in Foucault, 1994, t.4:180-181)

Les dominés (...) ne peuvent se constituer en groupe séparé, se mobiliser et mobiliser la force qu'ils détiennent à l'état potentiel qu'à condition de mettre en question les catégories de perception de l'ordre social qui, étant le produit de cet ordre, leur imposent la reconnaissance de cet ordre, donc la soumission.

Pierre Bourdieu, 1982 (in Bourdieu, 1982:151)

Ce n'est pas la simple présence du vrai qui le fait connaître comme vrai.

Louis Althusser, 1984-1987 (in Althusser, 1994a, I:69)

As relações sociais construídas pelo capital se estabelecem, se mantêm e se reforçam por meio de múltiplos mecanismos de dominação, administrados por diferentes tecnologias de poder e inculcados nos diversos aparelhos ideológicos do Estado, ou impostos repressivamente. Entre os autores decisivos para o entendimento dessas construções sociais históricas se destacam Marx, Althusser e Foucault. 


\section{A Subsunção do Trabalho sob o Capital}

Com a distinção entre a subsunção formal e a subsunção real do trabalho sob o capital, no esboço para o capítulo VI (chamado capítulo inédito) de $O$ Capital (Marx, 1968), Marx retoma sob esses conceitos a distinção entre a chamada acumulação primitiva e a acumulação capitalista. Encaminha assim a resolução do paradoxo que havia colocado no início do capítulo sobre a acumulação primitiva no Capital.

Hemos visto cómo se convierte el dinero en capital, cómo sale de éste la plusvalía y cómo la plusvalía engendra nuevo capital. Sin embargo, la acumulación de capital presupone la plusvalía, la plusvalía la producción capitalista y ésta la existencia en manos de los productores de mercancías de grandes masas de capital y fuerza de trabajo. Todo este proceso parece moverse dentro de un círculo vicioso, del que sólo podemos salir dando por supuesta una acumulación 'originaria' anterior a la acumulación capitalista ("previous accumulation", la denomina Adam Smith); una acumulación que no es resultado, sino punto de partida del régimen capitalista de producción. (Marx, 2000:607)

A implantação do capitalismo depende de que haja acumulação capitalista, que por sua vez depende da existência de capital, portanto acumulado previamente ao estabelecimento do capitalismo como tal. De acordo com Marx, essa acumulação se chama primitiva, ou originária, porque pertence à "préhistória do capital e do regime capitalista de produção" (Marx, 2000:608).

Os conteúdos históricos da subsunção formal e real do trabalho sob o capital já aparecem no capítulo da acumulação primitiva, embora aí se achem apenas indicados. Marx diz, por exemplo, que, quando na acumulação primitiva o capital converte diretamente o escravo e o servo da gleba em operário assalariado, determina uma simples "mudança de forma" (Marx, 2000:647). Desde então, vincula a acumulação do capital à expropriação dos meios de trabalho. Afirma que a acumulação primitiva "significa pura y exclusivamente la expropiación del productor directo” (Marx, 2000:647).

La propiedad privada fruto del propio trabajo y basada, por así decirlo, en la compenetración del obrero individual e independiente con sus condiciones de trabajo, es devorada por la propiedad privada capitalista, basada en la explotación del trabajo ajeno, aunque formalmente libre. (Marx, 2000:648) 
O regime do capital pressupõe a separação entre o operário e a propriedade dos meios de realização do seu trabalho. Diz Marx:

Cuando ya se mueve por sus propios pies, la producción capitalista no sólo mantiene este divorcio, sino que lo reproduce y acentúa en una escala cada vez. mayor. Por tanto, el proceso que engendra el capitalismo sólo puede ser uno: el proceso de disociación entre el obrero y la propiedad sobre las condiciones de su trabajo, proceso que de una parte convierte en capital los medios sociales de vida y de producción, mientras de otra parte convierte a los productores directos en obreros asalariados. (Marx, 2000:608)

O advento do capitalismo, que cria o assalariado e o capitalista, muda a forma de sujeição a que o trabalho é submetido, a exploração feudal se transforma em exploração capitalista (Marx, 2000). A expropriação que é antecedente necessário para o estabelecimento do capitalismo se faz com grande violência. Na realidade, diz Marx, os métodos da acumulação primitiva foram tudo, menos idílicos. "La expropiación del productor directo se lleva a cabo con el más despiadado vandalismo y bajo el acicate de las pasiones más infames, más sucias, más mezquinas y más odiosas” (Marx, 2000:648).

Antes de se estabelecer a subsunção real, o capitalista supervisiona um processo de trabalho já dado previamente, e o trabalho é subsumido apenas formalmente sob o capital. Até então, não há mudança essencial na forma real em que o trabalho é realizado. A jornada mais extensa e o trabalho mais intenso, mais contínuo e mais sistemático não mudam o caráter do modo real de trabalho. O que o capitalista persegue aí é a produção de mais-valia absoluta, procurando maximizar o produto e minimizar os custos da produção, especialmente o custo da utilização do trabalho.

Na subsunção formal do trabalho sob o capital, o processo de trabalho é para o capitalista processo de exploração de trabalho alheio. Depende de que o produtor direto tenha sido expropriado dos meios de produção, agora propriedade do capital. Já não tendo como garantir a própria subsistência, se vê assim compelido a vender não o seu trabalho, mas a sua força de trabalho em troca de um salário e, como assalariado, passa a trabalhar sob o comando, a supervisão e a direção do capital.

A relação-de-capital é uma relação de compulsão. Com a subsunção formal do trabalho sob o capital, essa compulsão não se baseia em nenhuma relação pessoal de dominação e dependência. Ela se instala basicamente em decorrência da diferença de funções econômicas. No modo de produção capita- 
lista, a subordinação que se estabelece entre vendedor e comprador da mercadoria força de trabalho não decorre de nenhuma subordinação de caráter político ou social que seja anterior à relação de compra-e-venda: “Ce n'est qu'en tant que propriétaire des conditions de travail que l'acheteur place le vendeur sous sa dépendance économique; il n'y a pas de rapport, politiquement et socialement fixé, de suprématie et de subordination" (Marx, 1968:370). A comparação feita aqui se dirige claramente às formas anteriores de organização da produção, em que o produtor direto não era formalmente livre para oferecer a sua força de trabalho a um comprador qualquer, pelos vínculos de subordinação que o prendiam à terra, ao senhor, à guilda etc., sob relações fixadas política e socialmente.

Enquanto prevalece uma subsunção formal do trabalho ao capital, instala-se, pois, uma relação econômica de dominação e subordinação entre trabalho e capital. Diz Marx:

Lorsque les rapports de domination et de subordination se substituent à l'esclavage, au servage, au vassalage, au patriarcat, etc., ils ne subissent qu'un changement de forme. Libres formellement, ils n'ont désormais qu'un caractère objectif, volontaire, purement économique. (Marx, 1968:372)

Há uma mudança na forma da relação de dominação e subordinação. Essa relação se torna mais livre. Como o trabalhador é formalmente livre, sua subordinação ao capital é formalmente voluntária. Neste sentido, é 'puramente econômica'. Marx indica, porém: 'Bien sûr, ce mode de production crée à son tour un nouveau rapport hiérarchique de domination et de subordination (lequel, de son côté, produit ses propres expressions politiques, etc.)" (Marx, 1968:371). O estabelecimento do modo de produção especificamente capitalista produz uma nova e efetiva relação de dominação e subordinação a partir do próprio processo produtivo, processo que antes se caracterizava por independência. $\mathrm{Na}$ organização social e do trabalho que prevalecia anteriormente, o produtor direto era subordinado a um senhor, à terra ou a um grêmio, mas na realização do seu trabalho dispunha de independência e de controle sobre o processo de trabalho. Com o capitalismo, ele perde essa independência.

Em seguida à expropriação do produtor direto ocorre a centralização dos capitais, que é inerente à produção capitalista. Esta centralização consiste na "expropriação de muitos capitalistas por uns poucos" e acarreta, como conseqüência, as mudanças profundas na própria maneira de produzir que caracterizam o capitalismo: 
...se desarrolla en una escala cada vez mayor la forma cooperativa del proceso de trabajo, la aplicación técnica consciente de la ciencia, la explotación sistemática y organizada de la tierra, la transformación de los medios de trabajo en medios de trabajo utilizables sólo colectivamente, la economía de todos los medios de producción al ser empleados como medios de producción de un trabajo combinado, social, la absorción de todos los países por la red del mercado mundial y, como consecuencia de esto, el carácter internacional del régimen capitalista. (Marx, 2000:648)

Assim se define a especificidade do modo capitalista de produzir.

Sendo capitalista a forma de produção, o processo de trabalho está sempre diretamente subordinado ao capital. Mas com o modo especificamente capitalista de produção, específico tecnologicamente e também sob outros aspectos, transforma-se a natureza real do processo de trabalho e suas condições reais. Diz Marx:

Avec elle [la subordination réelle du travail au capital], une révolution totale (et sans cesse renouvelée) s'accomplit dans le mode de production lui-même, dans la productivité du travail et dans les rapports entre le capitaliste et le travailleur. (Marx, 1968:379)

O modo de produção capitalista, segundo Marx um modo de produção sui generis, muda a configuração da produção material, sobre a qual se baseia a relação-de-capital.

Com a distinção entre subsunção formal e subsunção real do trabalho sob o capital, Marx procura marcar o 'grande contraste' entre o modo especificamente capitalista de produção e as formas anteriores, mesmo a forma imediatamente anterior, já sob o comando do capital. Somente com a subsunção real do trabalho sob o capital surge o modo de produção específico ao capitalismo, que não revoluciona apenas o tipo de trabalho e o modo real de todo o processo de trabalho, mas revoluciona também, ao mesmo tempo, as relações entre os diferentes agentes da produção. Com a implantação desse modo específico começam a se formar as relações de produção específicas dele; o capital estabelece relações de produção novas. É no interior do processo de trabalho que aqueles que antes apareciam apenas como comprador e vendedor da mercadoria força de trabalho se tornam agentes personificados dos fatores de produção: o capitalista funciona como 'capital' e o produtor direto como 'trabalho'. A relação que se forma entre trabalho e capital é determinada pelo trabalho. ${ }^{8}$ Aparece no início como meramente monetária, como relação entre um vendedor e um 
comprador - da nova mercadoria assim constituída, a força de trabalho. O processo de compra-e-venda dessa mercadoria, que aparece como uma relação entre possuidores de mercadorias dotados de direitos iguais, Marx diz que é apenas uma mediação - que é inerente ao modo de produção capitalista - que mascara como relação meramente monetária a relação propriamente capitalista subjacente, em que o trabalhador assalariado deve constantemente comprar de volta uma parte do seu próprio produto vendendo seu trabalho vivo. A renovação permanente da relação de compra-e-venda da força de trabalho mediatiza a continuidade da relação de dependência do trabalho ao capital que é específica do processo de produção capitalista.

No capítulo inédito, Marx conceitua os dois momentos da constituição do capitalismo como modo de produção particular e específico. A partir do processo de trabalho propriamente capitalista, o novo modo de produção constitui e coloca em confronto, de um lado, o trabalho, e de outro, o capital. No entanto, apesar desse confronto direto e diuturno na própria execução do trabalho, o processo produtivo capitalista mascara e mistifica as relações capitalistas que o engendram, de tal maneira que o que é produto do trabalho aparece ao trabalhador como se fosse produto do capital.

Marx identifica o processo de trabalho com o processo de valorização, porque supõe que é o trabalho despendido no processo produtivo que cria valor e sobre-valor (mais-valia). Assim, esse processo equivale ao processo do próprio capital. Mas o que é criação do trabalho aparece como se fosse criação do capital. De acordo com Marx, há uma mistificação que é inerente ao capitalismo:

la force de travail, conservatrice de la valeur, apparait comme la force du capital qui se conserve elle-même, la force de travail, créatice de la valeur, apparaît comme la force du capital qui se valorise elle-même. Dans l'ensemble, et par définition, le travail matérialisé apparaît comme l'employeur du travail vivant. (Marx, 1968:366)

Essa mistificação aumenta com a subsunção real do trabalho sob o capital, com o desenvolvimento da capacidade produtiva social ou socializada do trabalho, quando o caráter social do trabalho se confronta com o trabalhador como estranho a ele, hostil, antagônico, como capital personificado e objetivado.

A expansão do capital, produtora de muita riqueza, faz aumentar a miséria e a opressão de uma classe trabalhadora que o próprio mecanismo do processo de produção une, organiza e disciplina (Marx, 2000:648). 
Quando Marx formula e distingue a subsunção formal e a subsunção real do trabalho sob o capital, focaliza pontos essenciais para o entendimento do modo de produção capitalista: 1) que as relações de produção capitalistas se constroem com e no próprio processo produtivo capitalista, junto com a realização do trabalho na fábrica; 2) que os mecanismos de exploração e de dominação (submissão, subjugação) operam juntos, ditados pelo processo de trabalho e necessários a ele; 3) que todo esse processo constitui e contrapõe as duas classes fundamentais desse modo de produção: o trabalho e o capital; 4) que é inerente ao modo de produção capitalista a mistificação por meio da qual o que é produção do trabalho apareça como sendo produção do capital.

\section{Aparelhos Ideológicos de Estado}

Althusser tomou como objeto privilegiado da sua investigação as relações de dominação e subordinação engendradas pelas relações de produção capitalistas, especialmente por meio da ideologia, que supunha mistificadora. São conhecidos os seus primeiros grandes textos sobre a reprodução das relações sociais. Mas vários especialistas consideram que, especialmente entre 1976 e 1978, Althusser desconstrói (Sintomer, 'Présentation a Althusser', Althusser, 1998) ou mesmo destrói (Balibar, 1991) sua produção anterior. ${ }^{9}$ Em texto de 1993, Negri aponta a existência de uma 'Kehre' no pensamento de Althusser. ${ }^{10}$ Recorre aos Arquivos do Imec (Institut Mémoire de l'Édition Contemporaine) e se detém especialmente em textos inéditos ou em partes inéditas de textos já publicados. Aqui me interessa sobretudo a questão da 'sociedade capitalista da subsunção real', que Negri apreende no fundo da suposta 'Kehre' althusseriana. Segundo Negri, a transformação conceitual que ocorre nessa grande 'virada' do pensamento de Althusser consiste no aprofundamento contínuo da temática dos Aparelhos Ideológicos de Estado(AIE).

Sabemos que, inicialmente, Althusser considerava os AIE como os lugares da reprodução social, lugares de produção/reprodução da ideologia, cuja existência social e material se constituía nesses aparelhos e por meio deles. Adotava então a perspectiva da reprodução das relações sociais. Segundo Negri, a nova concepção althusseriana corresponde a uma nova realidade social engendrada pelo próprio desenvolvimento capitalista. Nessa nova realidade capitalista, a ideologia estende sua dominação massivamente sobre todo o real, configu- 
rando uma situação de dominação social totalitária da ideologia (Negri, 1993). Negri diz que Althusser define 'pós-moderno' "comme de l'expansion continu et de la contigüité totalitaire toujours plus intense du fonctionnement des AIE" (Negri, 1993:85). Entende que sobre essa continuidade e sobre essa contigüidade se efetua um salto qualitativo. Tal unificação dos AIE provoca uma "sobredeterminação da dominação", e essa ampliação "pós-moderna" do poder dos AIE unificados configura a "sociedade capitalista da subsunção real", em que a realidade social se confunde com a ideologia e o poder capitalista se reafirma como controle ideológico total.

Sobre o pensamento de Althusser a respeito da sociedade capitalista pósmoderna, Negri diz: “désormais l'exploitation plus qu'elle ne traverse les lignes de division entre les classes, s'insinue davantage dans les consciences et les dimensions subjectives de tous les acteurs sociaux" (Negri, 1993:86). Nesta sociedade em que o poder se funda no conjunto do processo social, o mundo é subsumido sob o capital. Pode-se presumir que esse poder é poder do capital, a dominação ideológica total é dominação do capital. Mas essa exploração que atravessa as linhas de divisão entre as classes e alcança todos não é, portanto, propriamente uma exploração de classe no sentido estrito. Negri, remetendo a Althusser, se refere a uma exploração que se insinua, para além das classes, sobre as consciências e a subjetividade de 'todos' os 'atores sociais'. A sociedade da dominação ideológica total é uma sociedade em que a exploração também é generalizada.

Estudando diretamente os textos de Althusser, pode-se verificar que a partir de 1976 ele revê e mesmo desconstrói muito da sua teorização anterior. Retifica alguns conceitos: fala em conjuntos contraditórios das ideologias, na existência tendencial de uma ideologia dominante, no papel importante da ideologia não apenas na reprodução, mas também na transformação das relações sociais (esp. Althusser, 1976, in Althusser, 1995b; Althusser, 1976, in Althuser, 1994a; e Althusser, 1972-1986, in Althusser, 1995a). Reforça outros conceitos, como o da materialidade da ideologia e da importância dos AIE (esp. Althusser, 1998, cap.13, e 1994a, II).

Nesse período, Althusser toma como objeto a crise do marxismo e entende que é preciso indagar à teoria marxista qual é sua parcela de responsabilidade nos horrores cometidos em nome do marxismo. Surge assim a necessidade de repensar Marx e o marxismo: 
Nous ne pouvons pas nous contenter de revenir en arrière, vers des positions qui auraient été seulement travesties ou trahies. La crise que nous vivons porte en elle des exigences nouvelles: elle nous oblige à changer quelque chose dans notre rapport au marxisme, et, par voie de conséquence, au marxisme même. (Althusser, 1998:273-274)

Althusser critica novamente o humanismo, critica a dialética, critica toda teleologia. E se volta para uma tradição materialista que reconhece desde Demócrito a Marx e Heidegger, em torno de categorias como vazio, limite, margens, ausência de centro, liberdade (Althusser, 1994a, I e 1994b, III). No entanto, há algo que nos primeiros grandes escritos $(1955-1967)^{11}$ fica praticamente fora da análise - embora permaneça como princípio assumido como tal - mas que nos últimos textos se torna parte integrante e com grande importância analítica: a questão das classes e da luta de classes. Por exemplo, falando da filosofia, afirma:

La tâche qui lui est assignée et déleguée par la lutte de classe en général, et plus directement par la lutte de classe idéologique, est celle de contribuer à l'unification des idéologies en idéologie dominante, et de garantir cette idéologie dominante comme Verité. (Althusser, 1994a, III:168)

O último Althusser recupera na análise da ideologia a perspectiva da transformação e entende a ideologia como parte da luta ideológica, componente específico da luta de classes.

Quanto à reprodução social, sua ênfase é na ideologia. Na entrevista a Fernanda Navarro, a propósito de uma questão sobre 'sujeito ideológico', Althusser diz:

C'est un fait que la reproduction sociale ne se réalise pas exclusivement à partir de la reproduction du travail, mais qu'elle suppose l'intervention fondamentale de l'idéologique. (...) Et bien que le moyen matériel pour reproduire la force de travail soit le salaire, celui-ci - comme nous le savons - ne suffit pas. Dès l'école, le travailleur a été 'formé' pour accomplir certaines normes sociales qui régulent des conduites: ponctualité, efficience, obéissance, responsabilité, amour familial et reconnaissance de toute forme d'autorité. Cette formation suppose l'assujetissement à l'idéologie dominante. (Althusser, 1994a, I:72-73)

No artigo de 1970 sobre os AIE (Althusser, 1995b:269-314), duas formulações são de grande interesse para a questão da subsunção real. Althusser diz que a reprodução das relações de produção é realizada pela materialidade 
do processo de produção e do processo de circulação através dos mecanismos desses processos e também pelo exercício do poder de Estado nos Aparelhos (os repressivos e os ideológicos) de Estado. Afirma ainda que, a não ser na ideologia dominante, não existe divisão técnica do trabalho, ou seja, toda divisão ou organização do trabalho constitui a forma e a máscara de uma divisão ou organização social (de classe) do trabalho. Reconhece, portanto, com toda a clareza, que a reprodução das relações sociais se faz primeiramente na 'materialidade do processo de produção', na qual a divisão e a organização técnicas do trabalho são a forma e a máscara de uma divisão e de uma organização sociais do trabalho. Reconhece ainda que essa divisão e essa organização sociais do trabalho são divisão e organização de classe. Desde os anos de crise, sempre que se refere à dimensão social, Althusser a entende em termos de classe, reservando o papel principal para as relações entre as classes como relações de exploração/dominação e de luta. É nesses termos que pensa a subordinação como parte da reprodução das relações sociais, preocupando-se permanentemente com a dimensão ideológica que a propicia.

Quando Negri fala do "totalitarismo da subsunção capitalista do social”, não parece estar expressando propriamente Althusser. Não encontro em Althusser referência ao conceito de subsunção da sociedade sob o capital. Minha hipótese de leitura é que se trata de uma interpretação feita por Negri sobre textos de Althusser que, no entanto, são formulados em outro registro conceitual. Uma leitura atenta revela que Negri explicita que a formulação da subsunção do mundo ao capital é sua, a partir do que lê em Althusser. Depois de dar conta dos novos estudos de Althusser sobre Maquiavel e sobre Spinoza, pergunta como fica, então, para Althusser, a relação entre a singularidade do trabalho vivo e a dominação abstrata do capital e do Estado, relação descrita por Marx e retomada por Althusser em Lire Le Capital (Althusser et al., 1965) e nos AIE. Negri (1993:82) diz que "ce rapport, considéré à d'autres moments dans son interaction, ne peut plus aujourd'hui être tenu pour tel”. Cita Althusser: "Maintenant les choses ont bien changé". E retoma a questão:

Que s'est-il passé vraiment? Il s'est passé que l'idéologie a massivement étendu sa domination sur tout le réel. Le réel se confond en grande partie avec l'idéologie. Si les AIE engendraient le pouvoir en le singularisant mécaniquement à travers diverses institutions, aujourd'hui ce pouvoir se fond dans l'ensemble du processus social. Le monde, dirions nous, a été subsumé sous le capital. (Negri, 1993:82, itálicos meus) 
$\mathrm{Na}$ verdade, a indicação parece clara de que quem fala de 'subsunção' não apenas especificamente do trabalho, mas 'do mundo' ou 'da sociedade' sob o capital, é Negri, interpretando Althusser quando este se refere à extensão massiva da ideologia sobre o conjunto do processo social. No entanto, como se trata de reflexões a partir de textos ainda inéditos, cabe manter a dúvida sobre se o próprio Althusser teria trabalhado nesses textos a "passagem à subsunção real da sociedade ao capital como totalidade do controle ideológico". É possível. Althusser assumiu idéias, conceitos e teses tão distintas das que havia adotado anteriormente que bem pode ter mudado quanto à questão da subsunção real.

\section{TeCnologias do Poder}

O que interessa sobretudo a Foucault é saber como funcionam as malhas do poder: "quelle est la localisation de chacun dans le filet du pouvoir, comment il l'exerce à nouveau, comment il le conserve, comment il le repércute" (Foucault, 1994:201). Trabalha com uma concepção de poder como tecnologia. Procura desembaraçar-se da concepção jurídica segundo a qual o poder é concebido a partir da regra, da lei, da proibição. Foucault quer discernir o funcionamento real do poder e não a sua representação. ${ }^{12}$ Entende que não há propriamente um poder, mas vários poderes, identificados com as formas de dominação e de sujeição que funcionam localmente (na oficina, no Exército etc.). Essas formas são heterogêneas e cada qual tem seu modo próprio de funcionamento, seus procedimentos e suas técnicas. A partir da existência inicial dessas pequenas regiões de poder se formam, pouco a pouco, os grandes aparelhos do Estado.

Foucault vincula o privilegiamento do poder como fato jurídico ao pensamento burguês e pretende seguir outro caminho para entender o poder. Quer alcançá-lo não na sua forma de Estado, pelo aparato político-jurídico do Estado, mas no seu funcionamento efetivo, que ele chama real, junto a cada um, a cada grupo, a cada classe. Pretende realçar as relações de dominação na sua multiplicidade, nas suas diferenças, na sua especificidade, na sua reversibilidade, para "essayer de repérer les differentes techniques de contrainte que (le pouvoir) met en œuvre" (Foucault, 1997:239). Busca, então, identificar táticas locais de dominação, instrumentos técnicos que asseguram as relações de dominação.

A sociedade é entendida por Foucault como um arquipélago de diferentes poderes, que não são simplesmente conseqüência de um poder central que 
seria primordial. Segundo ele, Marx mostra "comment, à partir de l'existence initiale et primitive de ces petites régions de pouvoir - comme la propriété, l'esclavage, l'atelier et aussi l'armée -, a pu se former, petit à petit, des grands appareils d'État" (Foucault, 1994:187). De acordo com Foucault, esses poderes locais não visam primeiramente proibir: eles têm como função essencial e permanente produzir uma eficiência, uma atitude.

Para Foucault, é preciso acompanhar a história dos saberes técnicos e tecnológicos no século XVIII. O que muitas vezes se considera como o progresso das Luzes, a luta do conhecimento contra a ignorância, da razão contra as quimeras, surge então como algo muito diferente: "un immense et multiple combat (...) des savoirs les uns contre les autres, par leurs détenteurs ennemis les uns des autres, et par leurs effets de pouvoir intrinsèques" (Foucault, 1997:159). A história desses saberes revela que eles são saberes múltiplos, independentes, heterogêneos e secretos e que o Estado intervém nas suas lutas, produzindo: 1) a eliminação e a desqualificação dos pequenos saberes inúteis e irredutíveis, economicamente onerosos; 2) a normalização dos saberes entre si, para tornar intercambiáveis os saberes e também aqueles que os detêm; 3) a hierarquização desses saberes; 4) uma centralização piramidal que permita controlar esses saberes, transmitir de baixo para cima os seus conteúdos e de cima para baixo a direção do conjunto e a organização geral que se quer fazer prevalecer (Foucault, 1997:161).

No entender de Foucault, o século XVIII foi o século da disciplinarização dos saberes a partir da 'ciência', que atuou como 'polícia disciplinar' dos saberes. O poder disciplinar se exerceu através da seleção, da normalização, da hierarquização e da centralização dos saberes. Foucault conclui que "sous ce qu'on a appelé le progrès de la raison, ce qui se passait c'était la mise en discipline de savoirs polymorphes et hétérogènes" (Foucault, 1997:162).

Foucault associa a invenção de novas tecnologias do poder ao desenvolvimento do capitalismo. Diz que é costume considerar como invenção decisiva nesse processo a máquina a vapor, mas encontra outras invenções tecnológicas às quais atribui importância igual ou mesmo maior do que aquela. Menciona tecnologias industriais e tecnologias políticas e entre estas destaca a disciplina e o controle. Encontra desde o fim do século XVII e durante o século XVIII o aparecimento de técnicas de poder essencialmente centradas no corpo individual. 
C'étaient toutes ces procedures par lesquelles on assurait la distribution spatiale des corps individuels (leur séparation, leur alignement, leur mise en série et en surveillance) et l'organisation, autour de ces corps individuels, de tout un champ de visibilité. C'étaient aussi ces techniques par lesquelles on prenait en charge ces corps, on essayait de majorer leur force utile par l'exercice, le dressage, etc. C'étaient également des techniques de rationalisation et d'économie stricte d'un pouvoir qui devait s'exercer, de la manière la moins coûteuse possible, par tout un système de surveillance, de hiérarchies, d'inspections, d'écritures, de rapports: toute cette technologie qu'on peut appeler technologie disciplinaire du travail. (Foucault, 1997:215)

A tecnologia disciplinar se centra no corpo individual - a vigiar, a vestir, a usar, a punir. A invenção da disciplina é assim uma forma de poder:

Comment surveiller quelqu'un, comment contrôler sa conduite, son comportement, ses aptitudes, comment intensifier sa performance, multiplier ses capacités, comment le mettre à la place où il sera plus utile: voilà ce qu'est, à mon sens, la discipline. (Foucault, 1994:191)

Na segunda metade do século XVIII, Foucault localiza a formação de uma outra tecnologia do poder, que não é disciplinar, mas não exclui a disciplina, a modifica, se implanta de algum modo nela e se estabelece graças a ela. Essa nova tecnologia se aplica à vida dos homens. Para Foucault, o controle é "l'autre grand noyau technologique autour duquel les procédés politiques de l'Occident se sont transformés. On a inventé à ce moment-là ce que j’appelerai, par opposition à l'anatomo-politique (...), la bio-politique” (Foucault, 1994:193). Isso ocorre quando

le pouvoir doit s'exercer sur les individus en tant qu'ils constituent une espèce d'entité biologique qui doit être prise en considération, si nous voulons précisément utiliser cette population comme machine pour produire, pour produire des richesses, des biens, produire d'autres individus. (Foucault, 1994:193)

De acordo com Foucault, estas são mudanças dos procedimentos políticos que acompanham a constituição do poder capitalista. Ambas são tecnologias do poder, cuja invenção "fait partie de ce développement dans la mesure où, d'un côté, c'est le développement du capitalisme qui a rendu nécessaire cette mutation technologique, mais cette mutation a rendu possible le développement du capitalisme" (Foucault, 1994:200). 
"Uma biopolítica da espécie humana", é como Foucault chama essa tecnologia que se dirige à multiplicidade dos homens enquanto "une masse globale, affectée de processus d'ensemble qui sont propres à la vie" (Foucault, 1997:216). Inclui um conjunto de processos, tais como

des processus de natalité, de mortalité, de longevité qui, justement dans la seconde moitié du XVIII ${ }^{e}$ siècle, en liaison avec tout un tas de problèmes économiques et politiques (...), ont constitué (...) les premiers objets de savoir et les premières cibles de contrôle de cette biopolitique. C'est à ce moment-là, en tout cas, que l'on met en œuvre la mesure statistique de ces phénomènes avec les premières démographies. (Foucault, 1997:216)

Em Foucault, a biopolítica - que se aplica, no limite, ao homem como espécie - é uma forma de "estatização do biológico" (Foucault, 1997:213).

A biopolítica lida com 'incapacidades biológicas diversas', tornadas objeto de saber, de cuidado e de políticas específicas por parte do poder. Foucault chama a atenção para o vínculo entre essa tecnologia de poder e o custo econômico das 'incapacidades biológicas diversas' a que se aplica. Destaca a importância das endemias enquanto "facteurs permanentes (...) de soustractions de forces, diminution du temps de travail, baisse d'énergies, coûts économiques, tant à cause du manque à produire que des soins qu'elles peuvent coûter. Bref, la maladie comme probème de population" (Foucault, 1997:217).

Assim, a instauração da biopolítica como tecnologia de poder trata de fenômenos que dão lugar a uma medicina que assume como função principal a higiene pública, através de organismos de coordenação dos cuidados médicos, de centralização da informação, de normalização do saber, e que se liga a todo um conjunto de procedimentos de medicalização da população (Foucault, 1997:217). Enquanto tecnologia de poder, a biopolítica já atuava por meio das instituições de assistência (muito mais antigas e em geral prestando uma assistência ao mesmo tempo massiva e lacunar), mas passa a atuar principalmente por meio de "mécanismes plus subtils, plus rationnels, d'assurance, d'épargne individuelle et collectif, de sécurité, etc." (Foucault, 1997:218).

Essa nova tecnologia de poder faz aparecer um elemento novo, não mais apenas o indivíduo como corpo, nem a sociedade como supostamente 'corpo' social, mas um novo corpo, "corps multiple, corps à nombre de têtes": é a noção de 'população', a população como problema ao mesmo tempo científico e político. Foucault ressalta a natureza dos fenômenos que desse modo 
são levados em consideração: são fenômenos coletivos, que só se tornam pertinentes como fenômenos de massa. Nas suas próprias palavras: "Ce sont des phénomènes qui sont aléatoires et imprevisibles si on les prend donc en euxmêmes, individuellement, mais qui présentent, au niveau collectif, des constantes qu'il est facile, en tout cas possible, d'établir" (Foucault, 1997:219). São fenômenos de série, que devem ser considerados num tempo mais ou menos longo, no curso de uma certa duração. Esse tipo de fenômeno é 'aleatório e imprevisível' quando considerado apenas na sua ocorrência singular, individual. Quando colocado como parte de um conjunto de fenômenos igualmente singulares, compreendidos numa duração mais ou menos longa, é possível estabelecer uma série do mesmo tipo, o que permite então tratá-los como generalidade e, nesse nível, alcançar suas determinações. A partir daí, torna-se possível fazer previsões e estimativas estatísticas. $\mathrm{O}$ objetivo não é intervir sobre um determinado fenômeno em particular, considerado em tal ou qual indivíduo singular. O que se pretende essencialmente é "intervenir au niveau de ce que sont les déterminations de ces phenomènes généraux, de ces phenomènes dans ce qu'ils ont de global" (Foucault, 1997:219). São, por exemplo, intervenções no sentido de baixar a morbidade, prolongar a vida, estimular a natalidade etc. Ou seja, essa tecnologia de poder tem a ver com a vida de uma população de seres vivos.

Com a biopolítica no sentido foucaultiano, visa-se estabelecer mecanismos reguladores numa determinada população considerada no seu conjunto, mecanismos que sejam capazes de manter um certo estado de equilíbrio quanto às variáveis pertinentes, "bref, d'installer des mécanismes de sécurité autour de cet aléatoire qui est inhérent à une population d'êtres vivants, d'optimaliser, si vous voulez, un état de vie" (Foucault, 1997:219). Tomar como objeto de regularização a vida, "os processos biológicos do homem-espécie" (Foucault, 1997:220). O poder que se investe nessa tecnologia do poder sobre a população é um poder contínuo, científico, "le pouvoir de "faire vivre"' (Foucault, 1997:220).

Foucault destaca a sexualidade como campo privilegiado para a operação dessa biopolítica - porque a sexualidade diz respeito, por um lado, ao corpo individual, mas por outro (em termos de procriação), se refere à população. Assim, situa-se ao mesmo tempo no eixo do organismo, corpo individual, e no eixo da população, fenômeno geral. Neste sentido, a investigação que realiza sobre a história da sexualidade é uma investigação sobre a biopolítica moderna. 
O último texto publicado em Dits et Écrits esclarece mais ainda esses conceitos:

\begin{abstract}
Nous pouvons dire, désormais, qu'à la fin du XVIII ${ }^{e}$ siècle la population devient le véritable objet de la police; ou, en d'autres termes, l'État doit avant tout veiller sur les hommes en tant que population. Il exerce son pouvoir sur les êtres vivants en tant qu'êtres vivants, et sa politique est, en conséquence, nécessairement une biopolitique. La population n'étant jamais que ce sur quoi veille l'État dans son propre intérêt, bien entendu, l'État peut, au besoin, la massacrer. La thanatopolitique est ainsi l'envers de la biopolitique. (Foucault, 1994:826)
\end{abstract}

Foucault trata, portanto, de poder: disciplinar e de controle (biopolítico). $\mathrm{Na}$ sua formulação, disciplina e controle são tecnologias do poder.

\title{
Perspectiva de Transformação, Resistência
}

Como todos os sistemas históricos, o capitalismo comporta contradições que, quando se agudizam, "the system reaches a point of bifurcation" (Wallerstein, 1999:74). Wallerstein acredita que há muitos indícios de que estamos hoje num ponto como este.

Mesmo admitindo a eficácia ainda maior da dominação ideológica através da ação cada vez mais contínua e contígua do sistema dos AIE, Althusser pensa que a dominação também produz resistência. Negri tem razão nesse ponto, quando percebe uma aproximação de Althusser com seu aluno e amigo Foucault. Mas existe entre eles uma diferença importante, em Althusser a resistência se vincula à luta de classes. Afirma Althusser: "Si les AIE ont pour fonction d'inculquer l'idéologie dominante, c'est qu'il y a résistance, s'il y a résistance, c'est qu'il y a lutte, et cette lutte est en définitive l'écho direct ou indirect, parfois proche ou le plus souvent lointain de la lutte des classes" (Althusser, 1995b:255).

O primeiro Althusser assumia o ponto de vista da reprodução e pensava a ideologia e sua eficácia apenas enquanto ideologia dominante. A perspectiva do dominado e da transformação estava ausente, o dominado só aparecia como assujeitado, subjugado. O último Althusser, porém, passa a admitir que a ideologia dominante é sempre incompleta, histórica, contraditória, parte das lutas de classe. Fala em sistema sempre contraditório das ideologias: "L'idéologie dominante n'est jamais en effet un fait accompli de la lutte de classe qui échappérait à la lutte de classe" (Althusser 1995b:254). 
Althusser diz que uma ideologia se torna dominante quando, com ela, a classe no poder consegue unificar-se e impor essa ideologia às massas exploradas como sendo ideologia delas. Diz, no entanto, que "cet état de choses, qui n'est jamais atteint, sauf périodes exceptionnelles, que tendanciellement dans l'histoire, suppose ce qui, contrairement à ce qu'on croit, ne va nullement de soi, à savoir, l'existence d'une idéologie dominante" (Althusser, 1994a,III:166). Quanto aos AIE, somente no Anexo do famoso artigo publicado em 1970 Althusser admitia a necessidade de incluir na análise as classes e a luta de classes. Já no texto de 1976, afirma que "les appareils idéologiques d’État sont nécessairement le siège et l'enjeu d'une lutte de classe, qui prolonge, dans les appareils de l'idéologie dominante, la lutte de classe générale qui domine la formation sociale" (Althusser, 1995b:255). Passa a incluir os dominados sob outra perspectiva que não exclusivamente a de assujeitados.

Como é possível que se formem resistências sob uma lógica de dominação total da sociedade? Onde essas resistências se tornam possíveis? Althusser fala em resistência e fala também em interstícios onde há ausência de relações mercantis:

Je soutenais alors l'idée que les 'îlots de communisme' existent dès aujourd'hui, dans les 'interstices' de notre société (interstices, mot que Marx appliquait (...) aux premiers noyaux marchands dans le monde antique), là où ne règnent pas des rapports marchands. Je crois en effet - et pense sur ce point être dans la ligne de la pensée de Marx - que la seule définition possible du communisme - s'il doit un jour exister dans le monde -, c'est l'absence de rapports marchands, donc de rapports d'exploitation de classe et de domination d'État. (Althusser, 1992:217; cf. também Althusser, 1998:285).

Por sua vez, Hardt e Negri pretendem, com o conceito de multidão, dar conta da 'nova realidade do capitalismo' e sobre essa nova realidade propõem, ou, nas suas próprias palavras, repropõem "o projeto político da luta de classes lançado por Marx” (Hardt \& Negri, 2005b:146). Assim, para além das diferenças, restrições e exclusões, a multidão abrange todos os que trabalham sob o domínio do capital e que potencialmente recusam esse domínio. Esse parece ser o projeto político para o qual tende a sua análise.

Para Hardt e Negri, "a multidão é um conceito de classe” e "a classe é determinada pela luta de classes” (Hardt \& Negri, 2005b:143,144). Argumentam que "as classes que importam são definidas pelo lineamento da luta coleti- 
va" e concluem: "a classe é um conceito político, em suma, na medida em que uma classe é e só pode ser uma coletividade que luta em comum" (Hardt \& Negri, 2005b:144). Assim, definem classe como sendo "efetivamente um conceito biopolítico" (Hardt \& Negri, 2005b:145). Por outro lado, Negri também entende multidão como "uma multiplicidade de singularidades que não pode encontrar unidade representativa em nenhum sentido". Diz que "os homens são singularidades, uma multidão de singularidades” (Negri, 2003:43).

Hardt e Negri encaminham cada vez mais claramente uma proposta de transformação por meio do que chamam 'multidão'. No diálogo com Danilo Zolo sobre Império, à pergunta sobre se eles pensam em uma transformação do mundo não somente política, mas também ética e cultural, Negri responde que eles vêem a revolução em termos éticos, políticos e de metamorfose biopolítica, "contra todas as estruturas centrais e periféricas do poder, para esvaziá-las e para subtrair ao capital a capacidade produtiva" (Negri, 2003:42). Apontam a possibilidade de construção de uma organização política alternativa ao Império, pela multidão. Dizem eles:

O Império com o qual nos defrontamos exerce enormes poderes de opressão e destruição, mas (...) oferece novas possibilidades para as forças de libertação. (...) As forças criadoras da multidão que sustenta o Império são capazes também de construir, independentemente, um Contra-Império, uma organização política alternativa de fluxos e intercâmbios globais. (Hardt \& Negri, 2005a:15)

Para eles, na realidade essa luta já começou.

Essa perspectiva de luta conduzida pela 'multidão' e pelos movimentos globais está presente em toda a produção recente de Hardt e Negri, explícita no que chamam de "projeto da multidão" (Hardt \& Negri, 2005b) e na perspectiva "da transformação e da possibilidade de uma nova ordem de valores e instituições, radicalmente democráticos” (Negri \& Cocco, 2005:15), que propõem. 
No capitalismo dependente, as relações que fundamentam a organização capitalista da sociedade são superdimensionadas e, portanto, se apresentam mais cruamente: a exploração é superexploração, a organização política oscila entre autocracia e ditadura, a concentração da renda e da propriedade é extremada (concentrando a riqueza, o poder e a cultura e ampliando exacerbadamente a polarização social), a dominação ideológica é maciça.

Uma sociedade assim constituída precisa construir o 'consenso' ininterruptamente, para o que mantém a informação sob controle estrito e bloqueia o acesso ao conhecimento e o confronto reflexivo e analítico entre possíveis formulações divergentes. Desqualifica-se a priori toda divergência e todo aquele que se opõe.

Portanto, para qualquer transformação mais profunda ou de maior fôlego nesta sociedade, a luta ideológica assume importância decisiva. Esse tipo de luta não prescinde do acesso mais geral possível ao conhecimento crítico e à sua análise e discussão.

Não se ultrapassa o 'consenso'/consentimento/submissão, que é construído ideologicamente pelo poder, sem questionar os quadros de pensamento estabelecidos e permanentemente reiterados pelas ideologias dominantes - que atuam como filtro do conhecimento e mesmo das informações e da percepção da realidade - e sem abrir espaços críticos de reflexão, que supõem elevação cultural geral.

Os movimentos de resistência ou de lutas se dão conta na sua prática dessas necessidades, tanto mais quanto mais pretendam ser autônomos frente às formas de poder e construir-se como espaços sociais alternativos - espaços de crítica e de democracia radical, onde não reinem relações mercantis.

\section{NOTAS}

${ }^{1}$ Jameson cita Ernst Mandel (Late Capitalism, 1978), que apresenta o capitalismo tardio como um terceiro momento na evolução do capital, que seria o mais puro estágio do capitalismo, mais do que qualquer dos seus momentos anteriores.

${ }^{2}$ Itálicos meus. Não havendo esse tipo de indicação, os itálicos das citações são dos originais.

3 “'Contemporary ancestors' or, conversely, 'primitive contemporaries"' (Latham, 2000:64).

4 "Even as the world became formally decolonized, modernizers continue to define the virtues of the 'advanced' nations in opposition to the intrinsic 'deficiencies' of the poorer 
ones, argued that contact with the West could only produce a beneficial, catalytic effort on 'backward' societies, and asserted that promoting global 'development' involved finding the right lessons in America's own historic past. Modernization theory resonated with previous combination of missionary vision and imperial control" (Latham, 2000:59-60).

${ }^{5}$ Para algumas das minhas análises sobre o capitalismo dependente em Florestan Fernandes, ver Cardoso (1996, 2005a).

${ }^{6}$ De fato, Max Weber faz a seguinte análise: “The capitalism of the middle ages began to be directed toward market opportunities (...) after the cities have lost their freedom. (...) Everywhere the military, judicial, and industrial authority was taken away from the cities. In form the old rights were as a rule unchanged, but in fact the modern city was deprived of its freedom as effectively as had happened in antiquity with the establishment of the Roman dominion, though in contrast with antiquity they came under the power of competing national states in a condition of perpetual struggle for power in peace or war. This competitive struggle created the largest opportunities for modern western capitalism. The separate states had to compete for mobile capital, which dictated to them the conditions under which it would assist them to power. Out of this alliance of the state with capital, dictated by necessity, arose the national citizen class, the bourgeoisie in the modern sense of the word. Hence is the closed national state which afforded to capitalism its chance for development - and as long as the national state does not give place to a world empire capitalism also will endure" (Weber, 1950:335, 337).

7 “...la marcha ulterior de la expropiación de los propietarios privados cobra una forma nueva. Ahora, ya no se trata de expropiar al trabajador independiente, sino de expropiar al capitalista explotador de numerosos trabajadores. Esta expropiación la lleva a cabo el juego de las leyes inmanentes de la propia producción capitalista, la centralización de los capitales. Cada capitalista desplaza a otros muchos. Paralelamente con esta centralización del capital o expropiación de muchos capitalistas por unos pocos ...” (Marx, 2000:648).

8 “....au sein du processus de la production, ce sont des agents qui en personnifient les facteurs, le capitaliste comme 'capital', le producteur immédiat comme 'travail', et leur rapport est déteminé par le travail, simple facteur du capital qui se valorise lui-même" (Marx, 1968:366).

${ }^{9}$ Deve-se considerar, no entanto, a observação de François Matheron, de que a relação dos últimos escritos com o conjunto da obra de Althusser não é simples, porque certamente há rupturas, mas também é possível descobrir nas suas notas de trabalho de 1966 "des remarques qui seront presque littéralement reprises dans ses derniers écrits: (...) Théorie de la rencontre (...)" (Althusser, 1994b:21).

${ }^{10}$ Para uma discussão que considera esta hipótese e se detém na produção do último Althusser, consultar Cardoso (2002).

${ }^{11}$ Adotando uma periodização indicada por Yves Sintomer (Althusser, 1998:8-9). 
12 "Je crois que c'est de cette conception juridique du pouvoir, de cette conception du pouvoir à partir de la loi et du souverain, à partir de la règle et de la prohibition qu'il faut maintenant se débarasser si nous voulons procéder à une analyse non plus de la représentation du pouvoir, mais du fonctionnement réel du pouvoir” (Foucault, 1994:186).

\section{REFERÊNCIAS BIBLIOGRÁFICAS}

ALTHUSSER, L. (em colaboração com É. Balibar, R. Establet, P. Macherey e J. Rancière). Lire Le Capital (Coleção "Théorie”), 2v. Paris: Maspero, 1965.

ALTHUSSER, L. L'Avenir Dure Longtemps. Paris: Stock, Imec, 1992.

ALTHUSSER, L. Sur la Philosophie. Paris: Gallimard, 1994a. I: Philosophie et marxisme: entretiens avec Fernanda Navarro (1984-1987), p.13-79; II : Correspondance (1984-1987), p.81-137; III: La transformation de la philosophie - Conférence de Grenade (1976), p.139-178.

ALTHUSSER, L. Écrits Philosophiques et Politiques. t. I. Textos reunidos e apresentados por François Matheron. Paris: Stock, Imec, 1994b. Présentation par François Matheron, p. 7-22 ; III: Le courant souterrain du matérialisme de la rencontre (1982), p.539-579.

ALTHUSSER, Lo. Écrits Philosophiques et Politiques. t. II. Textos reunidos e apresentados por François Matheron. Paris: Stock, Imec, 1995a. Machiavel et nous (1972-1986), p.39-168.

ALTHUSSER, L. Sur la Reproduction. Introdução de Jacques Bidet. Paris: PUF, 1995b. Note sur les AIE (1976), p.253-267; Idéologie et Appareils Idéologiques d'État (1970), p.269-314.

ALTHUSSER, L. Solitude de Machiavel. Edição preparada e comentada por Yves Sintomer. Paris: PUF, 1998. 8: Soutenance d'Amiens (1975), p.199-236; 11: Enfin la crise du marxisme! (1977), intervenção no Colóquio de Veneza, nov. 1977, p.267-280; 12: Le marxisme comme théorie 'finie' (1978), p.281-296; 13: Le marxisme aujourd'hui (1978), p.297-310.

ARRIGHI, G. O Longo Século XX: dinheiro, poder e as origens de nosso tempo. Rio de Janeiro, São Paulo: Contraponto, Unesp, 1996.

BALIBAR, É. Tais-toi encore, Althusser (1988). In: BALIBAR, É. Écrits pour Althusser. Paris: La Découverte, 1991.

BAUMAN, Z. Modernidade e Ambivalência. Rio de Janeiro: Zahar, 1999.

BENJAMIN, Wa. Sur le concept d'histoire. In: BENJAMIN, W. CEuvres, Tome III. Traduzido do alemão por Maurice de Gandillac, Rainer Rochlitz e Pierre Rusch. Paris: Gallimard, 2000. p.427-443.

BOURDIEU, P. Ce que Parler Veut Dire. Paris: Fayard, 1982. 
CALLINICOS, A. Against Postmodernism: a marxist critique. Cambridge: Polity Press, 1989.

CARDOSO, M. L. Ideologia do Desenvolvimento - Brasil: JK - JQ, 1972. Tese de Doutorado, São Paulo: Faculdade de Filosofia Letras e Ciências Humanas, Universidade de São Paulo. Publicada sob o título Ideologia do Desenvolvimento - Brasil: JK - JQ. Prefácio de Florestan Fernandes. 2.ed. Rio de Janeiro: Paz e Terra, 1978.

CARDOSO, M. L. Florestan Fernandes: a criação de uma problemática. Estudos Avançados, 10(26):89-128, 1996.

CARDOSO, M. L. Ideologia da globalização e (des)caminhos da ciência social. In: GENTILI, Pablo (Org.). Globalização Excludente: desigualdade, exclusão e democracia na nova ordem mundial. Petrópolis: Vozes, 1999. p.96-127.

CARDOSO, M. L. Sobre Althusser e a crise do marxismo. In: BOITO JR., A. et al. (Orgs.). A Obra Teórica de Marx: atualidade, problemas e interpretações. 2.ed. São Paulo: Xamã, 2002. p.107-121.

CARDOSO, M. L. Sobre a teorização do capitalismo dependente em Florestan Fernandes. In: FÁVERO, O. (Org.). Democracia e Educação em Florestan Fernandes. Campinas Niterói: Autores Associados, EdUFF, 2005a. p.7-40.

CARDOSO, M. L. Teorias da modernização e expansão capitalista. In: XII CONGRESSO BRASILEIRO DE SOCIOLOGIA, 31 de maio a 3 de junho de 2005, Belo Horizonte, Sociedade Brasileira de Sociologia, 2005b.

CARDOSO, M. L. Construindo o mundo do pós-guerra: a teoria da modernização. In: XXV CONGRESSO DA ASOCIACIÓN LATINOAMERICANA DE SOCIOLOGÍA (Alas), 22 a 26 de agosto de 2005, Porto Alegre, 2005c.

CÉSAIRE, A. Discours sur le Colonialisme. 1955. Paris \& Dakar: Présence Africaine, 1995.

CHESNAIS, F. A globalização e o curso do capitalismo de fim-de-século. Economia e Sociedade, 5, dez.1995.

CHESNAIS, F. A 'nova economia': uma conjuntura própria à potência econômica estadunidense. In: CHESNAIS, F. et al. Uma Nova Fase do Capitalismo? São Paulo: Xamã, Cemarx (IFCH-Unicamp), 2003.

DICKSON, A. K. Development and International Relations: a critical introduction. Malden: Polity Press \& Blackwell, 1997.

FERNANDES, Florestan. Sociedade de Classes e Subdesenvolvimento. Rio de Janeiro: Zahar, 1968. Cap. I: Sociedade de classes e subdesenvolvimento.

FERNANDES, F. Capitalismo Dependente e Classes Sociais na América Latina. Rio de Janeiro: Zahar, 1973. Cap. II: Classes sociais na América Latina. 
FERNANDES, F. A Revolução Burguesa no Brasil: ensaio de interpretação sociológica. Rio de Janeiro: Zahar, 1974.

FERNANDES, F. Brasil: em compasso de espera. São Paulo: Hucitec, 1980. Cap. 6: Um ensaio de interpretação sociológica. p.75-83.

FERNANDES, F. Nova República? Rio de Janeiro: Zahar, 1985.

FERNANDES, F. Em Busca do Socialismo: últimos escritos e outros textos. São Paulo: Xamã, 1995. Parte do capítulo 2: Capitalismo dependente e imperialismo.

FOUCAULT, M. Dits et Écrits. Paris: Gallimard, 1994. t. 4: Est-il donc important de penser? (Entretien avec Didier Éribon, 1981), p.178-182; Les mailles du pouvoir (1976), p.182-201; La technologie politique des individus (1982), p.813-828.

FOUCAULT, M. Il Faut Défendre la Société. Cours au Collège de France, 1976. Paris: Seuil/Gallimard, 1997.

GILMAN, N. Mandarins of the Future: modernization theory in Cold War America. Baltimore \& Londres: The Johns Hopkins University Press, 2003.

HABERMAS, J. The Philosophical Discourse of Modernity: twelve lectures. Cambridge: MIT Press, 1987.

HARDT, M. \& NEGRI, A. Império. Rio de Janeiro: Record, 2005a.

HARDT, M. \& NEGRI, A. Multidão. Rio de Janeiro: Record, 2005b.

HOBSBAWM, E. A Era dos Extremos: o breve século XX - 1914-1991. São Paulo: Companhia das Letras, 1997.

HORKHEIMER, M. \& ADORNO, T. W. Dialética do Esclarecimento. Rio de Janeiro: Zahar, 1985.

JAMESON, F. Postmodernism, or, The Cultural Logic of Late Capitalism. Durham: Duke University Press, 1991.

JAMESON, F. A Singular Modernity: essays on the ontology of the present. Londres e Nova York: Verso, 2002.

KELLEY, R. D. G. Freedom Dreams: the black radical imagination. Boston: Beacon Press, 2002.

KIELEY, R. Sociology \& Development: the impasse and beyond. Londres: UCL Press, 1995.

LATHAM, M. E. Modernization as Ideology: American social science and 'nation building' in the Kennedy era. Chapel Hill, Londres: The University of North Carolina Press, 2000.

MANDEL, E. Late Capitalism. Londres: Verso, 1978.

MARX, K. Introduction de 1857: contribution à la critique de l'économie politique. Paris: Éditions Sociales, 1957. 
MARX, K. Le Manifeste communiste (1848). Trad. M. Rubel e L. Évrard. In Karl Marx. Euvres: économie, I. Prefácio de François Perroux. Edição estabelecida e anotada por Maximilien Rubel. Paris: Gallimard (Bibliothèque de la Pléiade), 1965, p. 157-195.

MARX, K. Euvres: économie, II. Edição preparada e anotada por Maximilien Rubel. Paris: Gallimard (Bibliothèque de la Pléiade), 1968. Matériaux pour l'Économie' (1861-1865). I. Subordination formelle et réelle du travail au capital.

MARX, K. El Capital: crítica de la economía política. 3.ed, $1^{a}$ reimpressão. México: Fondo de Cultura Económica, 2000.

MEZZADRA, S. \& RAHOLA, F. The postcolonial condition: a few notes on the quality of historical time in the global present. Postcolonial Text, 2(1). Disponível em <htpp://www.pkp.ubc.ca/pocol/viewarticle>. Acesso em: 8 jan. 2006.

NEGRI, T. Pour Althusser: notes sur l'évolution de la pensée du dernier Althusser. In: ALTHUSSER, L. et al. Sur Althusser: passages. Paris: L'Harmattan, 1993.

NEGRI, A. Cinco Lições sobre Império. Com contribuições de Michael Hardt e Danilo Zolo. Rio de Janeiro: DP\&A, 2003.

NEGRI, A. \& COCCO, G. Glob(AL): biopoder e lutas em uma América Latina globalizada. Rio de Janeiro: Record, 2005.

PARSONS, T. Structure and Process in Modern Societies. Glencoe: The Free Press, 1960. cap.III.

THERBORN, G. 'Modernization': discourses, their limitations and their alternatives. In: SCHELKE, W. et al. Paradigms of Social Change: modernization, development, transformation, evolution. Frankfurt, New York: Campus Verlag, St. Martin Press, 2001. p.49-72.

WALLERSTEIN, I. The End of the World as We Know it: social science for the twenty-first century. Minneapolis, Londres: University of Minnesota Press, 1999.

WALLERSTEIN, I. Unthinking Social Science: the limits of the nineteenth-century paradigms. 2.ed. Com novo prefácio. Philadelphia: Temple University Press, 2001.

WEBER, M. General Economic History. Glencoe: The Free Press, 1950. 


\section{O Projeto Neoliberal para a Sociedade}

BRASILEIRA: SUA DINÂMICA E SEUS IMPASSES

Leda Maria Paulani

Já se tornou lugar-comum denominar a política econômica de nossos dias no Brasil de 'neoliberal'. Mas não é de hoje a popularidade do termo. Foi a partir do início dos anos 1990 que ele começou a ser mais difundido, acabando por adjetivar a política econômica das duas gestões de Fernando Henrique Cardoso. Não por acaso, quando da ascensão de Lula ao poder federal, muito se especulou a respeito do caráter neoliberal ou não de seu governo, tendo em vista ter sido o Partido dos Trabalhadores, por ele liderado, o crítico maior desse tipo de política ao longo de toda a era FHC.

Contudo, mais do que um mero rótulo, de resto necessário, dadas as profundas alterações processadas, vis-à-vis o momento anterior, na forma de pilotar câmbio e juros, na forma de gerir o Estado, na forma de induzir o movimento da economia privada, entre outras, o neoliberalismo tem uma história intelectual que merece ser lembrada, antes que nos perguntemos sobre a natureza do que se poderia chamar 'projeto neoliberal para a sociedade brasileira'. Além dessa história intelectual, que o constitui como doutrina, o neoliberalismo apresenta uma história concreta, que tem que ver com o momento histórico no qual suas prescrições passaram a ser adotadas. A relação entre o neoliberalismo como doutrina e coleção de práticas de política econômica, de um lado, e a fase específica do desenvolvimento capitalista que se inicia em fins dos anos 1970, de outro, não é casual nem trivial e também ela precisa ser recuperada para que possamos responder com propriedade não só à indagação referida como, também, às perguntas mais importantes para nosso país neste momento: como se deu a era neoliberal no Brasil? Que variante de sua concepção foi priorizada? 
Qual é o papel do Brasil na divisão internacional do trabalho nesse 'novo capitalismo'? Quais são as razões que nos legitimam a considerar como absolutamente neoliberal o atual governo? Quais são as perspectivas para o país se der continuidade a esse projeto? Quais são os maiores impasses por ele apresentados?

Para dar conta dessa tarefa, este texto está dividido em quatro seções, além desta introdução e de uma conclusão. Na primeira delas lembraremos a história intelectual do neoliberalismo, história que o coloca como doutrina, muito mais do que como teoria, e que o coloca também como um conjunto de práticas de política econômica. A segunda seção trata de indicar as características da nova fase experimentada pelo capitalismo desde meados dos anos 1970, marcada pela dominância financeira da valorização, bem como de relacioná-la à história concreta do neoliberalismo, seja como difusão da doutrina, seja como aplicação prática das políticas que ela prescreve. A terceira discute a divisão internacional do trabalho dessa nova etapa do capitalismo e o papel que cabe à economia brasileira. A quarta conta a história da era neoliberal no Brasil, desde o início, com Collor, até os dias atuais de Lula e seu contraditório e permanente estado de emergência econômica. A conclusão discute as transformações observadas nessa década e meia de neoliberalismo, os impasses que caracterizam essa etapa da história brasileira e as perspectivas que a partir daí se descortinam.

\section{A História intelectual do Neoliberalismo: O PÓS-GUERRA E O NEOLIBERALISMO COMO DOUTRINA}

A história intelectual do neoliberalismo está diretamente ligada à história do economista e pensador austríaco Friedrich Hayek. Nascido em Viena no último ano do século XIX, discípulo da chamada 'escola austríaca' de pensamento econômico, a produção teórica de Hayek até meados dos anos 1930, particularmente nos campos da teoria monetária e dos ciclos e da teoria do capital, foi marcada pelo apreço à idéia do equilíbrio e à importância que ele então conferia à teoria que o demonstrava. Aos não-economistas talvez caiba esclarecer que teoria do 'equilíbrio' significa a análise de oferta e demanda (sua constituição e sua dinâmica) e a demonstração de que, deixados a si mesmos, os agentes econômicos conseguem, por meio dos sinais emitidos pelo sistema de preços, chegar a um estado em que não se verifica excesso de demanda em nenhum mercado (o excesso de oferta é entendido como um excesso de de- 
manda negativo) e, portanto, a um estado em que todos os planos de venda e de compra são realizados com sucesso.

A teoria que demonstra esse caráter virtuoso do mercado (já que no final todos estão sempre plenamente satisfeitos) é a teoria neoclássica, tal como desenhada no início do século XX pelo economista inglês Alfred Marshall. A teoria neoclássica, de caráter dedutivo-nomológico, tem por fundamento o conceito do Homo economicus (o homem econômico racional) e encontra na teoria do valor-utilidade a base de seu raciocínio, descartando, portanto, a teoria do valortrabalho que caracterizara a ciência econômica em seus inícios (séculos XVIII e $\mathrm{XIX)}$, quando ela ainda era conhecida por economia política. ${ }^{1} \mathrm{O}$ equilíbrio, no sentido indicado, é o resultado lógico dessa visão dos agentes e de sua forma de comportamento.

Claro defensor dessa concepção durante um tempo substantivo de sua vida intelectual, Hayek, no entanto, muda radicalmente de postura em meados dos anos 1930. Num texto intitulado 'Economics and knowledge', escrito em 1936 e publicado em 1937 (Hayek, 1948), e em outros que se seguiram, ele faz uma crítica demolidora da teoria neoclássica e de sua idéia de indivíduo. Resumidamente, afirma que, ao tomar o indivíduo e seu comportamento como dados a priori, a teoria neoclássica dá por resolvido aquilo que deveria resolver. O equilíbrio que aparece como resultado de seu desenvolvimento está na realidade hipostasiado e, com isso, a teoria neoclássica, que deveria funcionar como a prova 'científica' de que a sociedade de mercado consegue produzir o ótimo social, não consegue cumprir esse papel.

Não é demais lembrar que Hayek foi um dos principais personagens de um debate ocorrido nesses mesmos anos e que ficou conhecido na literatura como 'debate sobre o cálculo socialista'. Por meio de artigos originais, réplicas e tréplicas que colocaram de um lado Hayek e von Mises e de outro economistas que defendiam o planejamento central, como o conhecido Oskar Lange, travou-se um debate em torno da possibilidade ou não de uma economia não organizada pelo mercado produzir uma situação de ótimo social. O resultado desse debate foi trágico para alguém com as arraigadas convicções liberais de Hayek. Lange não demonstrara apenas que o cálculo racional era perfeitamente possível numa sociedade não regida pelo mercado. Pior que isso, ele utilizara como peça fundamental em sua argumentação a própria teoria neoclássica. Se, como advoga a teoria neoclássica, o comportamento humano no que tange às questões materiais é plenamente previsível, ficava provado - assim raciocinou 
Lange - que o ótimo social podia ser conscientemente planejado, algo que Hayek não podia aceitar.

Outra informação biográfica importante é que Hayek, que ensinara em Viena até 1931, foi então convidado a assumir uma cadeira na já famosa London School of Economics, passando a fazer parte da comunidade intelectual inglesa. Tão logo chegou, envolveu-se numa polêmica com John Maynard Keynes e seus discípulos em Cambridge em torno de $A$ Treatise on Money, livro que o já famoso economista tinha publicado no ano anterior. A contenda entre os dois só fez crescer ao longo dos 15 anos em que Keynes ainda viveu, mas permaneceu mesmo depois da morte deste. Na contramão do que pensava Hayek, Keynes desenvolveu uma teoria para mostrar justamente que o mercado, deixado a si mesmo, poderia levar ao péssimo social, ou seja, trabalhar abaixo do nível de pleno emprego, produzindo recessão, desemprego e miséria por um tempo indefinido, visto que não tinha condições de, por si só, sair desse tipo de armadilha que seu próprio funcionamento montava. A enorme crise dos anos 1930, com todas as seqüelas sociais que produziu, funcionou como aliada poderosa da vitória de Keynes nessa contenda teórica. Mas, para além da disputa meramente intelectual entre os dois, ${ }^{2}$ o que estava em jogo nesses tempos era o destino do mundo moderno.

Terminada a Segunda Guerra, Hayek foi se dando conta de que o capitalismo caminhava a passos largos para uma era de regulações extranacionais (para evitar que o mundo fosse assolado novamente por conflitos bélicos que tinham questões econômicas em sua origem), de pesada intervenção estatal (para evitar crises catastróficas como a dos anos 1930) e de concessões aos trabalhadores (para enfrentar a concorrência ideológica operada pelo então chamado socialismo real). O acordo de Bretton Woods, ${ }^{3}$ o Estado keynesiano regulador de demanda efetiva e o Estado do Bem-Estar Social foram a consumação dessas expectativas, e esse mundo não agradava nem um pouco a Hayek. Por isso, em 1947, ele toma a iniciativa de convocar todos os expoentes do pensamento conservador de então (Lionel Robbins, Karl Popper, von Mises e Milton Friedman, entre outros) para uma reunião em que se discutiria a estratégia necessária para enfrentar essa avalanche de regulação e intervencionismo que assolava o capitalismo.

Essa reunião ocorreu na Suíça, em Mont Pèlerin, e tinha por objetivo "combater o keynesianismo e o solidarismo reinantes e preparar as bases para um novo capitalismo no futuro, um capitalismo duro e livre de regras" 
(Anderson, 1995:10). Para esses crédulos nas insuperáveis virtudes do mercado, o igualitarismo promovido pelo Estado do Bem-Estar e o intervencionismo estatal, que impedia as crises, destruíam a liberdade dos cidadãos e a vitalidade da concorrência, da qual dependia a prosperidade de todos. Mas a estratégia de Hayek e seus companheiros não passaria pelo desenvolvimento e/ou aprimoramento de uma teoria econômica que pudesse ser usada como arma na demonstração da superioridade do mercado e da sociedade que ele forjava. A teoria neoclássica, que seria, dentre todos, o paradigma com maior vocação para isso, tinha sido destruída metodologicamente justamente por Hayek.

Essa talvez seja a razão maior a explicar o fato de essa recriação do liberalismo ter nascido como doutrina e não como ciência. Se não havia teoria econômica capaz de cumprir o papel ideológico que era necessário cumprir, então tratava-se simplesmente de afirmar a crença no mercado, de reforçar a profissão de fé em suas inigualáveis virtudes. E para atingir o estágio em que o mercado seria o comandante indisputado de todas as instâncias do processo de reprodução material da sociedade, era preciso: limitar o tamanho do Estado ao mínimo necessário para garantir as regras do jogo capitalista, evitando regulações desnecessárias; segurar com mão de ferro os gastos do Estado, aumentando seu controle e impedindo problemas inflacionários; privatizar todas as empresas estatais porventura existentes, impedindo o Estado de desempenhar o papel de produtor, por mais que se considerasse essencial e/ou estratégico um determinado setor; e abrir completamente a economia, produzindo a concorrência necessária para que os produtores internos ganhassem em eficiência e competitividade. Com o passar do tempo, juntaram-se também a esse conjunto de prescrições regras de pilotagem de juros, câmbio e finanças públicas que, algo contraditoriamente, transformaram a política econômica neoliberal numa Business Administration de Estado. ${ }^{4}$ Mas esse último passo tem que ver com a história do próprio capitalismo e de sua relação com a história intelectual do neoliberalismo.

Segundo Harvey,

reunindo recursos oferecidos por corporações que lhe eram simpáticas e fundando grupos exclusivos de pensadores, o movimento [neoliberal] produziu um fluxo constante mas em permanente expansão de análises, textos, polêmicas e declarações de posição política nos anos 1960 e 1970. Mas ainda era considerado amplamente irrelevante e mesmo desdenhado pela corrente principal de pensamento político-econômico. (Harvey, 2004:130 $)^{5}$ 
De fato, é só a partir do final da última dessas décadas que passariam a existir as condições para a dominância da doutrina neoliberal e para a aplicação prática de seu receituário de política econômica. A próxima seção explica por quê.

\section{A História Concreta do Neoliberalismo: \\ A NOVA FASE DO CAPITALISMO E O NEOLIBERALISMO COMO PRÁTICA DE POLÍTICA ECONÔMICA}

O movimento de regulação e de intervenção estatal que marcou o capitalismo depois do término da Segunda Guerra produziu aquilo que ficou conhecido na literatura como 'os anos de ouro do capitalismo', ou seja, um período de quase trinta anos em que a economia cresceu aceleradamente no mundo todo, com desemprego muito baixo (praticamente no nível friccional) e inflação reduzida. É em meados dos anos 1970 que esse mundo vem abaixo, com as duas crises do petróleo (1973 e 1979), as crises fiscais dos Estados centrais e o retorno da inflação. A elevação dos juros americanos por Paul Vocker em 1979 é a consumação desse processo, que prepara o capitalismo para ingressar numa nova fase. Essa nova fase é marcada pela exacerbação da valorização financeira, pela retomada da força do dólar americano como meio internacional de pagamento, pela intensificação, em escala ainda não vista, do processo de centralização de capitais e pela eclosão da terceira revolução industrial, com o surgimento da chamada 'nova economia'. Detalhemos um pouco mais cada uma dessas características.

Em meados dos anos 1960, depois de um crescimento elevado e ininterrupto de cerca de vinte anos, que passara pela reconstrução da Europa e da Ásia e pela industrialização da América Latina, complicaram-se as perspectivas de continuidade desse processo de acumulação na mesma intensidade em que vinha acontecendo. Os capitais multinacionais que operavam na Europa, particularmente os americanos, passaram a buscar outras formas de valorização. Foram então se abrigar na city londrina, um espaço offshore, em que depósitos bancários em dólares circulavam fora do território americano e eram registrados em bancos situados fora dos Estados Unidos. ${ }^{6}$ Estimulado pelo recorrente déficit do balanço de pagamentos americano, foi-se criando assim um volume substantivo de capitais que buscavam valorização exclusivamente financeira, num movimento que foi-se desenvolvendo ao desabrigo de qualquer tipo de controle estatal. 
Entrementes, a economia americana crescia aceleradamente. $\mathrm{Na}$ realidade, o crescimento americano funcionava como uma locomotiva a puxar todo o crescimento mundial. A atmosfera de Guerra Fria e a aceitação das idéias de Keynes é que empurravam os Estados Unidos, desde o pós-guerra, para essa política de elevado crescimento interno e de estímulo ao crescimento do mundo capitalista como um todo. ${ }^{7}$ Assim, como tinham de dar conta de manter o poder hegemônico do país, as autoridades norte-americanas responderam com políticas expansivas à compressão das margens de lucro e à aceleração da inflação, que começaram a se esboçar na economia dos Estados Unidos na segunda metade dos anos 1960 .

Nesse contexto, o duplo papel que esse país tinha de desempenhar - de um lado, potência hegemônica e, de outro, detentor do monopólio da produção do meio de pagamento internacional - criava uma situação conflituosa e, no limite, insustentável, já que, no primeiro papel, os Estados Unidos tinham de estimular o crescimento interno e, com isso, a vitalidade do mundo capitalista, enquanto no segundo tinham de frear seu crescimento, para impedir que o dólar se fragilizasse. Em outras palavras, os Estados Unidos pagavam um preço pela manutenção da hegemonia de sua moeda, pois a relação nominalmente fixa entre ouro e dólar americano, que constituía a base do sistema concebido em Bretton Woods (por isso também conhecido por 'padrão dólar-ouro'), retirava das autoridades americanas preciosos graus de liberdade na condução de sua política econômica.

A aceleração inflacionária do final dos anos 1960 nos Estados Unidos tornou patente a insustentabilidade dessa situação. O crescimento do nível interno de preços em patamares mais elevados, combinado com a manutenção da paridade dólar/ouro, valorizava a moeda americana e aumentava a pressão sobre o governo para que fosse promovida uma desvalorização. Mas a perda de competitividade dos setores expostos à concorrência externa não era o único problema que a impossibilidade de desvalorizar o dólar provocava. O problema mais sério é que os déficits comerciais, até então praticamente inexistentes, começavam a se tornar substantivos. ${ }^{8}$ Isso implicava o aumento do passivo externo líquido dos Estados Unidos (crescimento de sua dívida externa) e, com isso, a redução das reservas americanas em ouro. ${ }^{9}$ Assim, "a idéia de que o dólar era as good as gold, que garantia sua aceitação internacional, seria minada” (Serrano, 2004:196).

Para enfrentar essa situação, cada vez mais insustentável, em 1971 o presidente americano Richard Nixon rompe unilateralmente com o sistema de 
Bretton Woods e desvincula o dólar do ouro. A partir dá inicia-se um período tumultuado no sistema monetário internacional, com um questionamento crescente da capacidade de o dólar americano continuar a funcionar como moedachave. Dentre outras idéias, começou a se cogitar a criação de uma moeda verdadeiramente internacional, tal como Keynes advogara em Bretton Woods, utilizando-se, como base para sua criação, os Direitos Especiais de Saque (DES), quotas de recurso que cada país possuía junto ao Fundo Monetário Internacional (FMI) e que podiam ser sacadas sem maiores formalidades. Evidentemente, transformações nessa direção não interessavam nem um pouco aos Estados Unidos, visto que perderiam um trunfo poderoso, que era dado justamente por sua posição de produtores do meio de pagamento internacional. Todo o potencial bélico de que dispunham poderia não ser suficiente para manter seu papel de potência hegemônica, se uma perda dessa dimensão viesse efetivamente a se confirmar.

Mas esse período de indefinição é resolvido, a favor do dólar, com a brutal elevação dos juros americanos promovida por Paul Volcker, presidente do Federal Reserve em 1979. Desde então, o dólar americano tem-se colocado como moeda hegemônica de uma forma ainda mais poderosa do que o fora nos 'trinta anos gloriosos', visto que, nas circunstâncias do padrão dólar autoreferenciado, ou padrão dólar-dólar, que acaba por se criar, a moeda americana tem todas as vantagens de que antes gozava, uma vez que mantém sua posição como moeda-chave do sistema, mas agora se beneficia disso sem ter de pagar o preço de sua vinculação a um lastro, em última instância, que era o papel desempenhado pelo ouro no padrão monetário anterior.

Não é sem conseqüências o fato de a resolução daquele período de indefinição ter se dado dessa forma. Dentre outras coisas, além de reforçar a hegemonia americana, o fortalecimento do dólar vem agindo como elemento de fundamental importância na manutenção da dominância financeira da valorização que marca a fase contemporânea do capitalismo. Mas, antes que caracterizemos essa fase, cabe retomar a história de sua constituição.

Depois de 1971, combinaram-se a continuidade do crescimento americano e mundial (ainda que a taxas menores do que as observadas no início dos trinta anos gloriosos), a elevação da inflação nos Estados Unidos, reduzidas taxas de juros nominais e reais em dólares e a crescente capacidade de criar crédito do circuito offshore de Londres. A conseqüência dessa combinação foi a explosão dos preços em dólar dos principais insumos industriais e, logo a se- 
guir, do petróleo (Serrano, 2004). Somente com a crise deflagrada pela Organização dos Países Exportadores de Petróleo (Opep), em 1973, o crescimento americano foi afetado, e em 1974 o mundo se encontrava em recessão aberta. O choque do petróleo e a profundidade da crise que se seguiu contribuíram decisivamente para a engorda geral dos capitais em busca de valorização financeira. Aos eurodólares já acumulados na city de Londres vieram se juntar os petrodólares e uma nova leva de eurodólares, agora com mais motivos ainda para deserdar da atividade produtiva, dada a recessão que atingia quase todo o mundo, particularmente o centro do sistema, ou seja, os países desenvolvidos. ${ }^{10}$ Os bancos privados internacionais com operações na city londrina se associaram para reciclar esses eurodólares e petrodólares, buscando tomadores dentre os países da periferia do sistema. Os países latino-americanos estiveram, portanto, entre as primeiras vítimas da sanha rentista desses capitais, já que muitos deles resolveram enfrentar com elevação de seu grau de endividamento a crise então experimentada. ${ }^{11}$ Evidentemente, o serviço da dívida paga pelos países em desenvolvimento, pelo menos até o estouro da chamada 'crise das dívidas' que assolou a América Latina a partir do final de 1979, só fez inchar ainda mais o volume desses capitais.

Foi esse acúmulo de capitais buscando valorização financeira que levou a uma pressão crescente e a uma grita geral pela liberalização dos mercados financeiros e pela desregulamentação dos mercados de capitais. O modo de regulação $\mathrm{O}^{12}$ do capitalismo, que funcionara no período anterior, dos anos dourados, não se adequava mais a um regime de acumulação que funcionava agora sob o império da valorização financeira. Volátil por natureza, logicamente desconectado da produção efetiva de riqueza material da sociedade, 'curtoprazista' e rentista, o capital financeiro só funciona adequadamente se tiver liberdade de ir e vir, se não tiver de enfrentar, a cada passo de sua peregrinação em busca de valorização, regulamentos, normas e regras que limitem seus movimentos.

Além da pressão pela desregulamentação, iniciou-se uma pressão pela elevação, mundo afora, das taxas reais de juros, ou seja, por regras de política monetária que favorecessem os interesses dos credores. ${ }^{13}$ Assim, a guinada monetarista dos Estados Unidos, exigida para a defesa da posição hegemônica do dólar e que levou à enorme elevação da taxa de juros americana no final de 1979 (elevação que se dá ainda no governo democrata de Jimmy Carter, mas que alcança os $20 \%$ ao ano no governo seguinte, do republicano Ronald Reagan), 
acabou por atender àqueles interesses, visto que, no rastro da taxa americana, subiram as taxas de juros nos principais países do centro do sistema, bem como aquelas segundo as quais se remuneravam os empréstimos concedidos aos países em desenvolvimento. ${ }^{14}$

Entrementes, o prolongamento da crise recessiva e a elevação dos juros levaram, em praticamente todo o mundo desenvolvido, ao endurecimento com a classe trabalhadora por parte das direções empresariais e dos governos. Nos Estados Unidos, esse ataque, que provocaria uma redução substantiva dos salários reais, toma a forma da confrontação e do enfraquecimento dos sindicatos, do término da política de rendas de Nixon e Carter e do avanço do processo de desregulamentação industrial, o qual facilita o movimento de aquisições e fusões, com a conseqüente reestruturação das empresas, as demissões numerosas e o abandono de acordos antes acertados com empregados sindicalizados (Serrano, 2004). Na Europa, onde o Estado do Bem-Estar Social tinha avançado substantivamente, essa mesma confrontação tomaria a forma de um ataque às conquistas sociais alcançadas pela classe trabalhadora.

A virada conservadora do capitalismo consagra-se de vez com a descoberta que Ms. Thatcher faz do pensamento neoliberal:

e foi Margareth Thatcher quem, buscando uma estrutura mais adequada para atacar os problemas econômicos de sua época, descobriu politicamente o movimento [neoliberal] e voltou-se para seu corpo de pensadores em busca de inspiração e recomendações, depois de eleita em 1979. Em união com Reagan, ela transformou toda a orientação da atividade do Estado, que abandonou a busca do bem-estar social e passou a apoiar ativamente as condições 'do lado da oferta' da acumulação de capital. O FMI e o Banco Mundial mudaram quase que da noite para o dia seus parâmetros de política, e, em poucos anos, a doutrina neoliberal fizera uma curta e vitoriosa marcha por sobre as instituições e passara a dominar a política, primeiramente no mundo anglo-saxão, porém, mais tarde, em boa parte da Europa e do mundo. (Harvey, 2004:130)

Como descobre Thatcher, o neoliberalismo constitui o discurso mais congruente com a etapa capitalista que se inicia, já que defende e justifica as práticas mais adequadas a esse novo momento. $\mathrm{O}$ discurso keynesiano do período anterior não servia mais. O estímulo à demanda agregada garantidor do pleno emprego, que implicava gastos públicos substantivos (com bens públicos e mecanismos de proteção social), não podia mais continuar, dada a crise que então se vivia e que atingia o próprio equilíbrio fiscal. Controlar os gastos do 
Estado aparecia também como a única saída para driblar a inflação, que insistia em ficar em níveis indesejados. Um desdobramento do mesmo mote é a pregação pela privatização de empresas estatais, que passam a aparecer como sorvedouros indevidos de dinheiro público. As regras, normas e regulamentações de toda ordem que o Estado impunha ao funcionamento do mercado tinham de ser abolidas ou reduzidas ao máximo possível, para que a concorrência gerasse seus frutos em termos de maior eficiência e recuperação dos lucros. Era preciso restringir o Estado às suas funções mínimas: diligenciar pela manutenção das regras que permitem o jogo capitalista e produzir os bens públicos por excelência, ou seja, justiça e segurança. Finalmente, a crise que comprimia as margens de lucros tinha de ser amenizada com redução de gastos com pessoal e flexibilização da força de trabalho, uma vez que as garantias sociais conferidas a esta última tornavam-se agora um custo insuportável e inadmissível.

Graças ao resgate então operado dos princípios neoliberais, construiu-se com muita facilidade um discurso que colocava no suposto gigantismo do Estado e em sua excessiva intervenção no andamento da economia as causas maiores da crise então experimentada, além dos privilégios que esse tipo de atuação tinha conferido aos trabalhadores ao longo dos trinta anos gloriosos. Assim, a pregação neoliberal aparece como o único remédio capaz de garantir ao sistema econômico a recuperação de sua saúde. Todas essas medidas promoveriam a libertação do mercado das correntes com que o Estado o amarrara, e os benefícios produzidos pela concorrência e pelos ganhos de eficiência que seriam produzidos logo se fariam sentir. Além disso, com a redução do espaço institucional de atuação do Estado, o setor privado, em princípio mais ágil e eficiente que a máquina estatal, porque regido pela lógica do mercado, retornaria ao lugar que de direito lhe era devido.

De um ponto de vista teórico, essa nova orientação substitui a política de controle da demanda efetiva, típica do período anterior, pela política 'do lado da oferta', que transforma a macroeconomia em microeconomia, já que cuida apenas da manutenção de um ambiente institucional favorável aos negócios (respeito aos contratos, direito dos credores tomado como sagrado, liberdade máxima para o capital, fim dos expedientes de regulação e controle), como se a disposição capitalista de investir dependesse apenas do animal spirit ${ }^{15}$ empresarial e não tivesse nada que ver com as expectativas em torno do comportamento da procura agregada, ou seja, das perspectivas de realização daquilo que Marx chamou de 'o salto mortal das mercadorias' (venda dos produtos). 
Sabendo, no entanto, que o processo de reprodução ampliada do capital se dá agora sob os imperativos da acumulação financeira, a leitura que se faz desse discurso muda inteiramente. A defesa dos interesses financeiros implica o controle obsessivo dos gastos do Estado por várias razões. A primeira delas é que, independentemente de se constituir ou não em âncora do sistema de preços, a taxa de juros paga pelo Estado aos papéis públicos transforma-se no piso a partir do qual todas as demais taxas (que diferem em função do tipo de operação, prazo e risco) são estabelecidas. Num mundo dominado pelos credores, não faz sentido permitir que o Estado, por conta de problemas no manejo da demanda agregada, opere taxas reais de juros muito reduzidas. Ao mesmo tempo, taxas de juros mais elevadas implicam crescimento das despesas do Estado com serviço da dívida, e é preciso que sobre espaço em outras despesas (gastos sociais, investimentos em infra-estrutura) para que esse aumento de despesas possa ser enfrentado. A segunda razão é que taxas de inflação mais elevadas são sempre 'pró-devedor', e como cabe ao Estado controlar a oferta de moeda, é preciso que ele não seja constrangido a aumentá-la indevidamente para fazer frente a gastos descontrolados. A terceira razão é que os papéis públicos são ativos financeiros por excelência. A garantia do controle dos gastos públicos, da taxa de inflação reduzida e do juro real elevado é ao mesmo tempo a garantia da remuneração real desse 'capital fictício', como o chama Marx. Uma parte substantiva dos impostos que o Estado recolhe a partir da geração efetiva de renda pela sociedade num determinado período de tempo é utilizada para enfrentar o serviço da dívida, de modo que os detentores desses ativos recebem uma parcela da renda real produzida nesse lapso, mesmo sem terem tido qualquer papel em sua produção. Ora, um Estado com gastos fora de controle induz a elevações da taxa de inflação, e isso, combinado ao juro real reduzido, problematiza a efetividade dessa transferência.

Por todas essas razões, afirmei anteriormente que, ao pacote inicial de medidas desenhado pelo movimento neoliberal (redução do Estado ao mínimo, inexistência de proteção ao trabalho, abertura da economia, liberdade para o funcionamento do mercado), acrescentou-se mais recentemente uma forma específica de pilotar câmbio, juros e finanças públicas que coloca a política econômica hoje no papel de business administration de Estado. Em outras palavras, brandindo-se os princípios neoliberais da eficiência, da rigidez de gastos, da austeridade, administra-se hoje o Estado 'como se fosse um negócio'. E é de fato disso que se trata, pois, contrariamente ao que ocorria na fase anterior, a 
atuação do Estado se dá agora visando preservar não os interesses da sociedade como um todo (emprego, renda, proteção social etc.), mas os interesses de uma parcela específica de agentes, cujos negócios dependem fundamentalmente dessa atuação. É o fato de o neoliberalismo ter se tornado prática de governo justamente nessa fase de exacerbação da valorização financeira que explica por que esse elemento foi adicionado ao pacote neoliberal. Porém, há mais no capítulo da gestão do Estado 'como se fosse um negócio'.

Pensadores críticos contemporâneos, como Harvey (2004), têm afirmado a tese de que estaríamos hoje num momento da história capitalista em que os processos típicos da fase da acumulação primitiva de capital se fariam presentes de modo muito mais intenso do que se imagina. ${ }^{16}$ Segundo tal visão, esses processos, que marcaram os primórdios do capitalismo e que envolvem fraude, roubo e todo tipo de violência, em realidade nunca saíram completamente de cena, mas se exacerbam quando ocorrem crises de sobreacumulação como a que agora experimentamos. O resgate desses expedientes violentos minoraria as conseqüências da sobreacumulação, visto que desbravaria 'territórios' para a acumulação de capital antes fora de seu alcance. Em outras palavras, estaríamos agora numa época de 'acumulação por espoliação', em que se aliam o poder do dinheiro e o poder do Estado, que dela participa sempre ou diretamente, ou por conivência ou por omissão. Vários são os exemplos desse tipo de processo. Os ataques especulativos a moedas de países fracos, o crescimento da importância dos títulos de dívida pública em todos os países e as privatizações, que se generalizaram, estão dentre os mais importantes. Em todos eles, sem a participação do Estado, sem sua administração em benefício do Business, esse tipo de acumulação primitiva não existiria.

Para dar um exemplo concreto, o processo brasileiro de privatização, que começou em 1990 e teve seu pico no primeiro reinado de FHC, é paradigmático. Por meio dele não só se abriram à acumulação privada suculentos espaços de acumulação, como, em muitos casos, se fez isso com dinheiro público (do BNDES), emprestado aos 'compradores' (e às vezes não pago, como no conhecido caso da Eletropaulo/Enron) a juros subsidiados. Além disso, os preços desses ativos foram subavaliados pelo Estado, e o ágio elevado que naturalmente apareceu, dada a concorrência por esses setores (os serviços industriais de utilidade pública), que são o filé mignon da acumulação produtiva no mundo, está sendo devolvido aos 'compradores' por meio de isenção fiscal que dura o tempo necessário para compensar o ágio. Outro exemplo concreto 
é a transformação pela qual vem passando o sistema previdenciário no Brasil. Com a imposição de tetos de valor reduzido para os benefícios, primeiro para os trabalhadores do setor privado (FHC), depois para os trabalhadores do setor público (Lula), o Estado abriu imediatamente à acumulação privada todo o imenso território da previdência, sendo que o governo Lula ofertou-lhe o presente mais valioso, os servidores públicos, de salário médio mais elevado e praticamente sem risco de desemprego.

A partir desses dois exemplos, ${ }^{17}$ pode-se resumir o fenômeno do qual estamos tratando. A gestão neoliberal do Estado implica conduzi-lo como se fosse um negócio, mas o resultado é o inverso do que ocorre quando essa racionalidade é aplicada ao setor privado. Em vez do acúmulo de recursos e da reprodução ampliada do 'capital público', temos dilapidação dos recursos do Estado, encolhimento de seu tamanho, atrofiamento do espaço econômico público, ${ }^{18} \mathrm{em}$ uma palavra: espoliação. Isso não quer dizer, no entanto, como já se tornou lugar-comum, que o Estado hoje seja fraco. Ao contrário, ele tem de ser extremamente forte, no limite violento, para conduzir os 'negócios de Estado’ da forma mais adequada possível de modo a preservar e contemplar grupos de interesse específicos. Na última seção deste texto, voltaremos a essa questão, diretamente relacionada à constituição de um 'estado de emergência econômico’. Antes disso, porém, é preciso, ainda nesta seção, explicar como as transformações operadas no setor produtivo estão diretamente ligadas à dominação financeira do processo de acumulação.

Em primeiro lugar, medidas como a terceirização, o contrato por tempo parcial e o trabalho com autônomos buscam não só a redução dos poros da jornada de trabalho como também a repartição, com a força de trabalho, do risco capitalista. Em segundo lugar, a difusão do toyotismo, como forma de organizar o próprio processo produtivo, é um expediente que acaba por se impor à antiga fórmula taylorista, porque, muito mais racionalmente do que esta, aproveita o valor de uso da força de trabalho em sua totalidade (habilidades físicas e mentais) e, melhor ainda, consegue isso economizando postos intermediários de gerência, já que faz com que os trabalhadores se vigiem uns aos outros, reduzindo-lhes a disposição de agirem como classe. ${ }^{19}$

Evidentemente, a ocorrência de todas essas transformações foi facilitada pelo abandono do pleno emprego como meta primeira da política econômica, já que níveis de atividade inferiores a esse fragilizam os trabalhadores, obrigando-os a aceitar qualquer coisa, desde que se preserve o espaço para a venda de 
sua força de trabalho. Assim, não é só circunstancialmente que o pleno emprego deixa de ser atingido. A despeito das oscilações cíclicas naturais que a acumulação capitalista experimenta, e que podem eventualmente fazer com que o produto se aproxime desse nível, sua busca deliberada como política de Estado é incompatível com a atual fase do capitalismo. Todos esses expedientes visam reduzir os gastos com mão-de-obra e recuperar as taxas de lucro, num contexto em que as possibilidades de ganho financeiro são substantivas.

É essa mesma circunstância que explica também outro expediente de gerenciamento típico dessa nova fase, que são os processos visando reduzir ao mínimo possível o tamanho dos estoques que o processo produtivo tem de carregar. Já que carregamento de estoques implica um tipo determinado de aplicação de capital, que pode não ser a mais lucrativa, dado esse ambiente, o setor produtivo foi buscar no comércio varejista, particularmente no setor de supermercados, as técnicas necessárias para minimizar esse 'custo'. Finalmente, cabe lembrar que o abandono da produção em massa verificado em muitos setores e sua substituição pela chamada 'costumeirização' da produção (produção feita de acordo com a demanda do cliente) busca a divisão do risco capitalista com os consumidores, além de ser bastante funcional num contexto em que o carregamento de estoques é reduzido a seu mínimo.

Todo esse conjunto de transformações, que mudou a face do sistema produtivo, busca em última instância conferir ao capital a flexibilidade necessária para que aproveite as oportunidades de acumulação onde quer que elas se encontrem (no setor produtivo, no setor financeiro, nos negócios de Estado). $\mathrm{Na}$ regulação fordista que caracterizou a fase anterior, as formas institucionais que vinculavam capital monetário e trabalho, capital produtivo e meios de produção, capital mercadoria e produtos acabados eram fórmulas rígidas, incompatíveis com um ambiente de acumulação em permanente ebulição. É esta a razão que leva alguns autores, como Harvey (2000), a afirmarem que essa fase da história capitalista é caracterizada por um 'regime de acumulação flexível', que é outra forma de falar do regime de acumulação sob dominância financeira, já que flexibilidade é uma das características constitutivas do capital financeiro.

O abandono do pleno emprego como objetivo gerou uma situação em que há uma espécie de 'estado permanente de crise' (eventualmente interrompido por espasmos de crescimento mundial, como o que observamos nos últimos dois ou três anos). ${ }^{20}$ Ora, como previu Marx, é justamente nas crises que se acentuam os processos de centralização do capital, uma vez que a maior dificul- 
dade de engendrar os processos de reprodução ampliada faz com que muitos pequenos capitais sejam absorvidos por capitais maiores. Junte-se a essa 'condição natural' do capital o fato de esse processo estar se dando num contexto de absoluta desregulação por parte dos Estados nacionais e temos o maior processo de concentração de capital da história capitalista, com uma série de setores econômicos dominados mundialmente, na maior parte dos casos, por não mais que uma dezena de grupos empresariais.

Já em 1994, Chesnais (1996) detectava, por exemplo, que, no setor de hardware (incluindo microcomputadores, sistemas médios e sistemas de grande porte), quatro empresas eram responsáveis por $53 \%$ da produção mundial, enquanto dez empresas respondiam por $67 \%$. Se restrito ao segmento dos sistemas de grande porte, esses mesmos números saltam para 76\% e 91\%, respectivamente. No setor de automóveis, a situação não é muito diferente: 12 empresas respondendo por $78 \%$ da produção mundial. Nos casos de pneus e de material médico, os números são, respectivamente: seis empresas respondendo por $85 \%$ da produção e sete empresas respondendo por $90 \%$.

O que aconteceu com o setor de telefonia pública em âmbito mundial nos anos 1980 é indicativo da velocidade e da intensidade desse processo de centralização, que envolve não só a absorção de pequenos capitais por grupos de grande porte como, também, os processos de fusão desses grandes capitais, em muitos casos motivados por resultados buscados nas cotações desses grandes grupos no mercado bursátil. O mesmo Chesnais (1996) indica que, em 1982, sete grupos detinham 58,3\% desse mercado, enquanto que, em 1987, esse mesmo grupo detinha $70 \%$, só que agora reduzido a quatro grandes grupos, dadas as fusões ocorridas entre a americana IT'T e a francesa Alcatel, e entre a americana GTE e a alemã Siemens, além da incorporação da holandesa Philips pela gigante americana AT\&T. Não é demais notar que tudo isso aconteceu no exíguo prazo de cinco anos.

Também no setor de serviços a concentração é expressiva: 16 empresas, sendo cinco americanas e cinco alemãs, detinham 54\% do mercado mundial de resseguros em 1986; 16 empresas, sendo dez americanas, detinham 61\% do mercado mundial de publicidade em 1989; e, no mesmo ano, seis empresas, todas americanas, detinham $62 \%$ do mercado mundial de consultoria e gestão estratégica (Chesnais, 1996).

Completamos, com isso, o diagnóstico e o desenho dessa nova fase da história capitalista, além de termos mostrado qual é a relação de sua emergência 
com o fortalecimento do discurso neoliberal, bem como com a aplicação prática das medidas por ele prescritas. Faltaria apenas relacionar todo esse quadro com o surgimento da chamada 'nova economia'. Mas esse elemento está diretamente ligado à reflexão que faremos a seguir sobre o papel que cabe às economias periféricas, como a brasileira, dentro dessa nova ordem.

\section{O Brasil na nova Divisão Internacional do TrABALHO}

Observamos anteriormente que, impulsionado por uma espécie de 'permanente estado de crise', o movimento de centralização atingiu intensidade inédita na história capitalista, com a constituição de grandes massas de capital que dominam vários dos setores industriais e de serviços. Observamos também que, nos Estados Unidos, o avanço do processo de desregulamentação industrial facilitou o movimento de aquisições e fusões, com a conseqüente reestruturação das empresas, demissões e abandono de acordos com os sindicatos. Por trás desses dois movimentos está uma transformação substantiva no estado-da-arte da concorrência intercapitalista, transformação que foi se constituindo ao longo dos anos 1970 e 1980.

Como mostram alguns autores, com destaque para Chesnais (1996), o processo de aquisições e fusões que se intensificou a partir da crise de meados dos anos 1970 foi acompanhado da transnacionalização dos grandes grupos de capital, movimento que implica não só muito mais liberdade para suas decisões como também o estabelecimento, em várias das instâncias do processo de produção e realização do valor e com variados graus de profundidade, de terceirizações, franchising, parcerias e acordos de cooperação entre estruturas empresariais no plano mundial. Segundo Chesnais, essa transformação foi de tal ordem que provocou enorme discussão, entre os especialistas em organização industrial, sobre a natureza desses movimentos:

Nos últimos vinte anos, assistiu-se a uma extensão considerável da gama de meios que permitem à grande empresa reduzir seu recurso à integração direta (...). Essa evolução suscitou muitas discussões em economia industrial. No caso dos acordos de cooperação tecnológica, por exemplo, as novas formas de relações entre companhias têm sido caracterizadas, por certos autores, como sendo situadas 'em algum lugar entre os mercados e as hierarquias' e, por outros, como acarretando um 'reques- 
tionamento profundo do princípio de internalização'. Analogamente, as modalidades recentes de acordos de terceirização são apresentadas por alguns como 'um novo tipo de patronato' e, por outros, como formas de 'quase-integração vertical'. (Chesnais, 1996:104)

Essas diferentes modalidades de externalização da produção e da reprodução do capital permitem aos grandes grupos mundiais a consolidação de seu poder econômico e de sua capacidade oligopolista, num momento em que se exige do capital a maior flexibilidade possível. A enorme gama de procedimentos de que eles hoje dispõem para organizar e reforçar esse poder implica, na maior parte dos casos, o estabelecimento de relações assimétricas perante o universo de capitais operando no planeta. As exigências de uma etapa da acumulação dominada pelos imperativos típicos da valorização financeira vão empurrando os grandes grupos de capital não só a dividir o risco capitalista com os trabalhadores (trabalhadores 'autônomos', contratação por projetos etc.) e com os consumidores (costumeirização), mas também com o pequeno capital. São bastante conhecidas a esse respeito as histórias de grupos como a Nike, que detêm o controle de um enorme número de pequenos produtores domésticos espalhados por todo o planeta, particularmente nos países periféricos, e de outros, como a Benetton, que pura e simplesmente administra uma marca, por trás da qual se encontram milhares de unidades produtivas igualmente espalhadas pelo globo.

A transnacionalização do capital, ao fazer com que os grandes grupos econômicos considerem "o mundo todo como espaço relevante para suas decisões de produção e investimento" (Pochmann, 2001:251), aparece como o outro lado da moeda da mundialização financeira e constitui um dos traços mais marcantes da configuração do capital produtivo nessa etapa da história capitalista. São substantivas e pouco alvissareiras as conseqüências dessa reconfiguração para a forma de inserção dos países periféricos no sistema-mundo capitalista. ${ }^{21}$ Entre os anos 1950 e 1970, o que as empresas multinacionais pretendiam, porque precisavam disso (buscavam novos mercados), era a internalização de duplicatas de suas plantas industriais na periferia do capitalismo. Já na década de 1990 o que marca a estratégia dos grupos transnacionais é a busca permanente de se livrar dos investimentos de longa duração, ganhando flexibilidade para explorar oportunidades lucrativas. Isso faz com que as grandes corporações, num movimento desenfreado, operem 'deslocalizações' de suas atividades, inclusive de sua capacidade produtiva, para qualquer lugar do planeta, sempre que isso for visto como 
uma possibilidade de redução de custos. Com isso, muitas vezes, as atividades transferidas são aquelas mais simples e rotineiras, como as operações de montagem, enquanto as etapas mais complexas do processo produtivo (concepção do produto, definição do design, pesquisa e tecnologia, marketing) terminam, na maior parte dos casos, não sendo externalizadas.

É evidente que a industrialização periférica que ocorre nesses moldes não pode ter como resultado maior homogeneização do espaço econômico mundial, especialmente em termos de geração de renda, como tendia a acontecer na etapa anterior, visto que a atratividade desses espaços para as grandes corporações está muito mais nos baixos custos do que nas potencialidades dos mercados locais. Do lado dos candidatos a recebedores desses 'investimentos', há uma corrida frenética no sentido do oferecimento de condições satisfatórias ao máximo possível para atraí-los. Isso implica não apenas forte subsídio estatal direto ou indireto como, principalmente, a supressão de direitos trabalhistas, com a desregulamentação e a flexibilização dos mercados de trabalho. ${ }^{22}$

Por isso, um dos resultados mais perversos dessa nova divisão internacional do trabalho é a intensificação das possibilidades de extração de mais valor por meio da criação de mais-valia absoluta. Num país como o Brasil, onde essas práticas nunca foram de fato deixadas de lado, a combinação dos elementos citados tende a transformar o país, do ponto de vista da produção industrial, num grande chão de fábrica nos moldes daqueles do período inicial da industrialização no centro do sistema, ou seja, com precariíssimas condições de trabalho, jornadas sem fim e uma massa de trabalho vivo sem a menor qualificação, no melhor estilo taylorista. ${ }^{23}$

Porém, mesmo com todas essas 'vantagens' para o capital transnacional, que vai tendo como conseqüência a redução permanente da qualidade dos postos de trabalho gerados pela indústria, o Brasil vem experimentando, desde o início dos anos 1980, um claro retrocesso no perfil de suas atividades e na forma de sua inserção na produção mundial. Não se trata apenas de, no setor industrial, o país estar produzindo cada vez mais bens que são considerados quase commodities (alta escala de produção, baixo preço unitário, simplificação tecnológica e rotinização das tarefas). Trata-se de uma redução acentuada da importância do setor industrial brasileiro, como indica o fato de o emprego industrial nacional ter chegado a representar 4,2\% do emprego industrial mundial, nos anos 1980, e de essa participação ter chegado hoje à casa dos 3,1\% (Pochmann, 2001). 
O relatório da Conferência das Nações Unidas sobre o Comércio e Desenvolvimento (Unctad) de 2003 classifica os países em desenvolvimento em quatro grupos: ${ }^{24}$ os de industrialização madura, como Coréia e Taiwan, que apresentam decréscimo no crescimento industrial porque já teriam atingido um grau elevado de industrialização; os de industrialização rápida, como China e Índia, que têm logrado elevadas taxas de investimento doméstico mediante políticas industriais e de incentivo às exportações; os de industrialização de enclave, como o México, que a despeito de terem conseguido aumentar sua participação na exportação de manufaturados têm tido desempenho insuficiente em termos de investimento, valor agregado e produtividade total; e os países em vias de desindustrialização, cujo rótulo é por si só suficiente para entender do que se trata. Neste último grupo encontram-se vários países da América Latina, dentre eles a Argentina e o Brasil. Essas economias caracterizam-se por queda ou estagnação dos investimentos e participação da produção manufatureira no PIB em declínio. Segundo Belluzzo (2005), as décadas de 1980 e 1990 presenciaram no Brasil um processo de desindustrialização relativa, com o rompimento dos nexos interindustriais das principais cadeias de produção e com a redução substantiva do setor de bens de capital, movimento esse que, em termos macroeconômicos e de contabilidade nacional, significa uma redução do valor agregado interno sobre o valor bruto da produção.

Assim, em tempos de predominância da chamada 'nova economia' aceleração da difusão das tecnologias de informação e de comunicação e retomada do crescimento da produtividade do trabalho -, o Brasil engatou a marcha a ré. $\mathrm{Na}$ explicação desse movimento perverso há, de um lado, um fator estrutural, mas há de outro um fator político. Francisco de Oliveira (2003) dá conta de explicar o primeiro. Para ele, o paradigma molecular-digital, que caracteriza essa nova economia, ${ }^{25}$ além de trazer unidas ciência e tecnologia e de estar trancado nas patentes, não sendo, portanto, universalizável, é descartável e efêmero, exigindo um esforço permanente de investimento que está sempre além das forças internas de acumulação dos países periféricos. Nesse contexto, o que resta a esses países a título de 'desenvolvimento tecnológico' são apenas os bens de consumo, o descartável que eles podem (e devem) copiar. O Brasil, por exemplo, é hoje um dos grandes produtores de celulares, mas sua atuação limita-se às atividades já rotinizadas de fabricação e montagem, estando muito longe das atividades de pesquisa e tecnologia responsáveis pela evolução assombrosa de seu conteúdo tecnológico. 
Mas como adiantamos, na história da regressão experimentada pelo país no último quarto de século não há apenas esse elemento, que tem que ver com a evolução estrutural do capitalismo. Outras áreas periféricas, como mostra o relatório da Unctad, vêm se saindo melhor na empreitada de engatar suas economias à economia global e propiciar, ao mesmo tempo, a geração interna de investimento e emprego. Nesses países (os dos dois primeiros grupos) houve e há uma preocupação em estabelecer políticas industriais e de incentivos às exportações que fomentem o investimento e o aumento do conteúdo tecnológico das manufaturas, permitindo a apropriação do aumento das vendas externas pelo circuito interno de renda (Belluzzo, 2005). Para que se complete, portanto, a explicação do retrocesso brasileiro é necessário adicionar, à questão das transformações maiores por que passa o capitalismo, um fator sociopolítico interno, já que, como observou Marx, a articulação das formas econômicas inclui a política como seu elemento estruturante.

É preciso inicialmente lembrar que a necessidade de não deixar passar o bonde da história foi o argumento mais forte dos arautos do neoliberalismo para, no Brasil do início dos anos 1990, advogar as medidas liberalizantes que nos levariam ao admirável mundo novo da globalização. Esse discurso que, para os olhos mais críticos, sempre pareceu tão-somente uma desculpa para justificar a submissão incondicional do país a interesses a ele alheios, foi a arma utilizada para convencer uma população recém-saída da ditadura, com o movimento de massas se estabelecendo e se institucionalizando, de que seria esse o único caminho para tirar o país da crise em que ingressara nos anos 1980 - que, como sabemos, foi produzida pela elevação das taxas de juros americanas e pela estagnação do crescimento e pelo acirramento da inflação que se seguiu. Nesse processo, o papel das elites foi de extrema importância. Ainda que não estivessem disso exatamente conscientes, a possibilidade de internacionalizar de vez seu padrão de vida, juntamente com a possibilidade, que ficaria ao alcance da mão, de desterritorializar sua riqueza, fez com que as elites brasileiras, que padecem de crônico sentimento de inferioridade, abraçassem incondicionalmente o discurso neoliberal e o defendessem com unhas e dentes, ainda que, contraditoriamente, acabassem por utilizar os elementos da receita neoliberal, como as privatizações e a necessidade de superávit nas contas públicas, para hierarquizar e 'pessoalizar' as relações de mercado.

Abraçado o projeto neoliberal, vendeu-se a idéia de que o Brasil pegaria o bonde da história pela via do comércio exterior. A esse respeito, ficou célebre 
um artigo de Gustavo Franco - 'Inserção externa e desenvolvimento econômico', que circulou informalmente em 1996 - em que o ex-presidente do Banco Central, então seu diretor da área externa, demonstrava, por meio de um modelo, de que maneira as medidas modernizantes, com destaque para a abertura econômica, iriam produzir um choque de produtividade na economia do país, permitir a conquista de um lugar ao sol no comércio globalizado e ainda por cima distribuir renda. Mas o Brasil entrou no bonde da história por outra porta e transformou-se em plataforma de valorização financeira internacional, bem em linha com o espírito rentista e financista dos dias que correm. Esse seu papel, juntamente com sua função de produzir bens de baixo valor agregado e de preferência com a utilização de mais-valia absoluta (afinal de contas, o custo irrisório da mão-de-obra é nossa verdadeira 'vantagem comparativa'!), completa a caracterização da participação do Brasil na divisão internacional do trabalho do capitalismo contemporâneo. A apresentação em mais detalhes deste último papel será feita na seção a seguir, pois ela vai ficando visível na própria história da era neoliberal em nosso país.

\section{A Era Neoliberal no Brasil}

O discurso neoliberal no Brasil começou a se afirmar e a fincar raízes nas eleições presidenciais de 1989. Ainda atolado num problema inflacionário que parecia insolúvel, mas ao mesmo tempo esperançado com as conquistas expressadas na nova Constituição que fora elaborada um ano antes, o país ficou dividido entre o discurso 'liberal-social' de Collor e o discurso popular e democrático de Lula e do Partido dos Trabalhadores. Ecoando o arrazoado da desestatização da economia, que nascera no governo Figueiredo por conta das pendengas do capital nacional relativamente aos arranjos do II PND (Plano Nacional de Desenvolvimento), advogando a necessidade da transparência e da austeridade nos gastos públicos e embrulhando tudo isso na pregação moralista da 'caça aos marajás', Collor vence as eleições e dita, para o próximo período, a agenda de transformações que ele pouco concretizaria. Passados os tumultuados anos desse primeiro governo civil - seqüestro de ativos, aproximação da hiperinflação, impeachment do presidente -, o então ministro da Fazenda, Fernando Henrique Cardoso, embalado no sucesso do Plano Real, vence as eleições de 1994 (mais uma vez contra Lula) e assume o governo federal no início de 1995 com o declarado projeto de 'modernizar' o país, mais particularmente suas instituições. Esse princípio básico 
de seu projeto tomou a forma concreta de um ousado e ambicioso plano de privatizações e de uma abertura substancial da economia. Mas, junto com essas realizações, uma série de outras providências foi tomada em paralelo para transformar o Brasil numa economia financeiramente emergente, a começar da própria estabilização monetária, obtida no ano anterior. Vejamos isso mais de perto.

O Brasil do final dos anos 1980 não estava adequadamente preparado para desempenhar o papel de economia financeiramente emergente. Em primeiro lugar, as altas taxas de inflação que persistiam por aqui produziam abruptas alterações no nível geral de preços e em sua variação. Nessas condições, complicava-se sobremaneira o cálculo financeiro que comanda a arbitragem com moedas e a especulação visando a ganhos em moeda forte (a taxa de câmbio real e a taxa real de juros sofrem contínuas oscilações). Em segundo lugar, com o caráter fortemente centralizado e regulado da política cambial de então, a valorização financeira porventura alcançada não tinha a liberdade necessária para pôr-se a salvo, em caso de turbulência. Portanto, não só os ganhos eram incertos, como não havia segurança de que seriam efetivamente auferidos, na eventualidade de existirem.

Outro problema, também provocado pela persistência do fenômeno da alta inflação, ${ }^{26}$ era a dificuldade de controlar os gastos do Estado. No caso do Brasil, com uma história muito particular no que concerne ao processo de indexação, ${ }^{27}$ a complicação era ainda maior, ensejando a criação de um semnúmero de conceitos de déficit para lidar com a situação. Tendo em vista o caráter rentista desse tipo de acumulação, e considerando que uma de suas bases mais importantes é a dívida pública, a anarquia nos gastos públicos produzida pela alta inflação era uma complicação e tanto, pois precarizava a extração de renda real que deve valorizar esse 'capital caído do céu', em que se constituem esses papéis. ${ }^{28}$

O tamanho e o grau de intervenção do Estado na economia constituíam um problema adicional, que se complicara ainda mais com os deveres adicionais que a Constituição de 1988 lhe tinha criado, pois um Estado com tantas demandas e tantas tarefas não tinha como garantir ganhos reais às aplicações financeiras, nem como se 'especializar' na administração das finanças e na gestão da moeda.

O ambiente no qual os negócios aconteciam também não ajudava, visto que, em caso de colapso empresarial, a legislação então vigente punha à frente dos direitos dos credores financeiros os direitos dos empregados e os direitos do Estado. Para os credores do Estado a situação não era muito 
diferente, pois não havia nenhum dispositivo capaz de exercer um controle mais rigoroso dos governantes no sentido de garantir que os compromissos financeiros fossem honrados.

$\mathrm{Na}$ questão previdenciária estava mais um sério obstáculo para que o país de imediato se integrasse à mundialização financeira. Nosso sistema previdenciário era marcado pelo regime de repartição simples, caracterizado pela solidariedade intergeracional e pela posição do Estado como seu principal ator. Esse sistema não combinava com os novos tempos, não só por conta do peso dessas despesas no orçamento público, mas pela privação, sofrida pelo setor privado, de um mercado substantivo e promissor, até então praticamente monopolizado pelo Estado.

Começando no governo Collor, atravessando Itamar e as duas gestões de FHC e chegando a Lula, quase todas as transformações necessárias para enfrentar esses obstáculos foram feitas, em conjunto com as privatizações e a abertura comercial. Como já mencionamos, a difusão cada vez maior do discurso neoliberal é que foi produzindo, desde o governo Collor, os argumentos necessários para promover, num país recém-democratizado, com um ativo movimento social e ainda comemorando as 'conquistas' de 1988, esse tipo de mudança. Desde a eleição de Collor, passou a ser voz corrente a inescapável necessidade de reduzir o tamanho do Estado, privatizar empresas estatais, controlar gastos públicos, abrir a economia etc. Os ganhos prometidos iam do lugar ao sol no mercado global ao desenvolvimento sustentado, da manutenção da estabilidade monetária à distribuição de renda, da evolução tecnológica à modernização do país. Collor não teve tempo para pôr em marcha esse projeto - a não ser muito timidamente o processo de privatização -, mas a referida pregação ganhou força inegável e passou a comandar todos os discursos.

É no governo Itamar que têm lugar as primeiras mudanças de peso no sentido de preparar o país para sua inserção no circuito internacional de valorização financeira. Em 1992, a diretoria da área externa do Banco Central, em meio às negociações para internacionalizar o mercado brasileiro de títulos públicos e securitizar a dívida externa, resolvendo a pendência que vinha desde 1987, encarregava-se também, na surdina, de promover a desregulamentação do mercado financeiro brasileiro e a abertura do fluxo internacional de capitais. ${ }^{29}$

A partir de mudanças operadas nas chamadas contas CC5 - contas exclusivas para não-residentes, que permitiam, graças a uma lei de 1962, a livre 
disposição de recursos em divisas -, o Banco Central abriu a possibilidade de qualquer agente, independentemente de ser ou não residente, enviar livremente recursos ao exterior, ${ }^{30}$ bastando, para tanto, depositar moeda doméstica na conta de uma instituição financeira não-residente. ${ }^{31}$

Essas mudanças produziram, em conjunto, a forma e a substância da inserção do Brasil nas finanças de mercado internacionalizadas. O lançamento de títulos de dívida brasileira cotados no exterior confirmou o país no papel de emissor de capital fictício, que viabiliza a valorização financeira e garante a posteriori a transferência de parcelas da renda real e do capital real para essa esfera da acumulação. A liberalização financeira vem garantir o livre trânsito dos capitais internacionais, que podem assim maximizar o aproveitamento das políticas monetárias restritivas e de juros reais elevados. Sem o destravamento do mercado, por exemplo, os mais de US\$ 40 bilhões que saíram do país entre setembro de 1998 e janeiro de 1999, atemorizados com a iminente desvalorização do real, não teriam podido fazê-lo, amargando duras perdas.

Ainda no governo Itamar surge o Plano Real. Vendido como um mero plano de estabilização, absolutamente necessário em virtude dos problemas produzidos pela persistência da alta inflação (desestruturação das cadeias produtivas, elevado imposto inflacionário, que prejudica principalmente as classes de renda mais baixa, deterioração da capacidade fiscal do Estado etc.), o Plano Real foi em verdade muito mais do que isso. Em primeiro lugar, ele resolveu o problema que impedia praticamente o funcionamento do país como plataforma de valorização financeira internacional. Mesmo com a abertura financeira já tendo sido formalmente operada, ela permaneceria letra morta, do ponto de vista de suas potencialidades em termos de atração de capitais externos de curto prazo, se o processo inflacionário não tivesse sido domado. Além disso, o plano abriu espaço para uma série de outras mudanças que teriam lugar no governo de FHC. A abertura da economia, as privatizações, a manutenção da sobrevalorização da moeda brasileira, a elevação inédita da taxa real de juros, tudo passou a ser justificado pela necessidade de preservar a estabilidade monetária conquistada pelo Plano Real. Por essas e outras é que se pode dizer que, a partir do Plano Real, há um sentimento difuso de 'emergência econômica', no sentido de exceção, que acompanha a emergência do país como promissor mercado financeiro. Tudo se passa como se aos poucos estivesse sendo decretado um estado de exceção econômica, o que justifica qualquer barbaridade em nome da necessidade de salvar o país, 
ora do retorno da inflação, ora da perda de credibilidade, ora da perda do bonde da história... Voltaremos a esse tema na análise do momento atual.

É também no contexto das mudanças institucionais necessárias para colocar o Brasil como emergente mercado financeiro que se deve analisar a edição, em maio de 2000, da Lei Complementar no 101 (Lei de Responsabilidade Fiscal - LRF). A partir da LRF, negociada por FHC com o FMI no calor da crise que levou à desvalorização do real em janeiro de 1999, a preocupação central do administrador público passa a ser a preservação das garantias dos detentores de ativos financeiros emitidos pelo Estado. Por um lado, o propósito da LRF era e é estabelecer uma hierarquia nos gastos públicos que coloca em primeiríssimo e indisputável lugar o credor financeiro, em detrimento da alocação de recursos com fins distributivos (políticas de renda e políticas públicas de modo geral) e da viabilização de investimentos públicos. Por outro lado, a 'austeridade fiscal' da LRF, que exige de prefeitos e governadores esse tremendo aperto e a redução impiedosa dos gastos na área social, não impõe nenhum controle ou sanção aos que decidem a política de juros e elevam a dívida pública do país em favor dos credores nacionais e internacionais.

Além da consolidação do Plano Real com as privatizações e a abertura comercial, os oito anos de FHC produziram uma série de benefícios legais aos credores do Estado e ao capital em geral, que não deixaram dúvidas quanto à seriedade de suas (boas) intenções para com esses interesses. Em carta ao FMI de setembro de 2001, o governo brasileiro reafirmou sua disposição para estudar meios de evitar ou reduzir o impacto negativo da CPMF nos mercados de capitais. Em dezembro do ano seguinte, aprovou-se a Emenda Constitucional $\mathrm{n}^{\circ} 37$, que isenta da incidência desses tributos os recursos aplicados em bolsas de valores. No mesmo sentido, passou a ser isenta de imposto de renda a distribuição de lucros de empresas a seus sócios brasileiros ou estrangeiros e a remessa de lucros ao exterior. ${ }^{32}$

Dentro do espírito de guarnecer o país dos dispositivos institucionais necessários para sua inserção na mundialização financeira, o governo FHC promoveu ainda uma mudança substancial no sistema previdenciário. Conforme já adiantado, o sistema previdenciário brasileiro era estruturado predominantemente pelo regime de repartição simples e constituía praticamente um monopólio do Estado. Esse tipo de regime é marcado pela chamada solidariedade intergeracional (quem trabalha gera renda para quem não trabalha), sendo, portanto, tanto mais equilibrado financeira e atuarialmente quanto maiores forem o 
crescimento, o emprego e o rendimento médio dos trabalhadores. Pretextando déficits insustentáveis que acabariam por sufocar o Estado, ${ }^{33}$ o governo de FHC começa, em 1998, a mudar esse sistema, elevando o prazo para a requisição dos benefícios e impondo tetos (bastante reduzidos) para seu pagamento. Ao promover essas alterações, o governo aumenta por tabela a importância da previdência privada, que passa a ser necessária para complementar a futura aposentadoria. Começa assim a se construir o mercado privado de previdência, já há alguns anos reivindicado pelo sistema financeiro.

Ao contrário do que ocorre no regime de repartição simples, no regime de capitalização, que caracteriza o mercado privado, não há solidariedade intergeracional. Cada um responde apenas por si e tem um retorno futuro proporcional a sua capacidade de pagamento corrente. Aos gestores desses fundos cabe administrar os recursos neles depositados por longo período, de modo a garantir o rendimento financeiro necessário para honrar os compromissos previdenciários futuros. Sendo assim, por um lado, esse regime busca a maior liquidez, no menor período de tempo, e com o menor risco possível, o que torna os títulos de renda fixa, particularmente os títulos da dívida pública, os ativos por excelência de seus portfólios. É claro que, dada essa lógica, os fundos de pensão serão tão mais bem sucedidos quanto maiores forem as taxas de juros. Por outro lado, quando aplicam em renda variável (ações), eles buscam evidentemente aqueles papéis com maior capacidade de valorização, e esses papéis são, hoje, aqueles pertencentes às empresas que melhor executam os programas de dowsizing, de terceirização e de flexibilização de mão-de-obra. Assim, o equilíbrio financeiro desses fundos está na dependência de um comportamento das variáveis-chave macroeconômicas que é perverso do ponto de vista do crescimento e do emprego, pois joga no sentido da elevação dos juros básicos, da redução da mão-de-obra formalmente empregada e da queda do rendimento médio dos trabalhadores. A perversidade desse comportamento é parte das contradições inerentes a um sistema que vê diminuir o capital produtivo - que gera renda real - enquanto engorda o capital financeiro - que extrai renda real do sistema e incha ficticiamente nos mercados secundários, exigindo ainda mais renda.

Porém, por mais que tentasse, FHC não conseguiu implementar, na questão previdenciária, todas as mudanças requeridas para que sua conformação se adaptasse ao novo figurino, já que sua reforma ficou restrita aos trabalhadores da iniciativa privada. Por incrível que pareça, a reforma visando estender essas 
mudanças também aos trabalhadores do setor público foi justamente o primeiro projeto de fôlego em que se empenhou o governo Lula no início de sua gestão. A exemplo do que FHC fizera com a previdência dos trabalhadores do setor privado da economia, o projeto de Lula, além de estender os períodos de contribuição, passou a prever tetos (reduzidos) de benefícios também para os trabalhadores do setor público. (Mas, diferentemente de FHC, que não ousou dispensar as 'regras de transição', a proposta original do governo do PT foi ao parlamento sem elas, cabendo aos congressistas a introdução das mudanças que tornaram 'menos radical' a reforma proposta). ${ }^{34}$

Ao completar a transformação idealizada por FHC, mataram-se vários coelhos de uma só cajadada. Para começar, criou-se finalmente o grande mercado de previdência complementar que há mais de duas décadas vinha despertando a cobiça do setor financeiro privado, nacional e internacional. Cabe ressaltar que, dessa forma, a viabilização da reforma no setor público representa a abertura de perspectivas de acumulação que não estão presentes quando se considera o mercado previdenciário oriundo do setor privado da economia. Apesar de substancialmente maior do que o número de trabalhadores do setor público, o mercado constituído pelos empregados do setor privado possui renda média menor e enfrenta a ameaça do desemprego. A abertura desse novo e gordo espaço de valorização foi, portanto, o primeiro dos grandes tentos marcados pelo governo Lula com a aprovação da reforma. Além disso, com a elevação das contribuições, da idade e do tempo de trabalho para a obtenção do benefício, ao lado da taxação dos inativos, o governo contou pontos também no intocável objetivo do 'ajuste fiscal'. Pôde ainda, por meio de um bem-pensado programa de defesa publicitária dessa iniciativa, colocar os funcionários públicos como os grandes vilões do descalabro social do país (recuperando, sintomaticamente, a 'caça aos marajás' da campanha de Fernando Collor) e vender a idéia de que o intuito da reforma era simplesmente o de fazer 'justiça social'.

Concluída essa reforma, ficou quase pronto o país para participar do circuito da valorização financeira. Mais alguns detalhes, como a nova Lei de Falências (aprovada em fevereiro de 2005), ${ }^{35}$ a autonomia do Banco Central (que continua firme e forte na agenda do governo Lula), ${ }^{36}$ o aumento da DRU (Desvinculação de Recursos da União), sua prorrogação para além de 2007 e a extensão desse expediente também para os níveis estadual e municipal, e nada mais faltará. ${ }^{37} \mathrm{~A}$ autonomia do Banco Central garantirá que a política monetária 
será conduzida sempre de modo a honrar o pagamento do serviço da dívida e a premiar, com juros reais substanciais, os detentores de papéis públicos. Tem em seu auxílio a DRU, que também funciona como o instrumento mais afiado para dar cabo dos estorvos promovidos pela Constituição de 1988. A Lei da Responsabilidade Fiscal (que alguns chamam, com justeza, de Lei da Irresponsabilidade Social) contribui com sua parte, ao assegurar que os papéis emitidos por instâncias inferiores do Poder Executivo também tenham seu serviço honrado, enquanto a nova Lei de Falências trata privilegiadamente o credor financeiro, em caso de bancarrota privada.

Ora, um país tão sério e cônscio não só da necessidade de cumprir as obrigações financeiras como, também, de premiar com elevado rendimento os detentores de ativos financeiros merece um lugar de destaque em meio aos 'emergentes', com direito até a aspirar ao investment grade. A tendência, portanto, é que a financeirização da economia brasileira se internacionalize cada vez mais. Como fica claro, a inserção externa do Brasil não se deu pela via do comércio exterior, conforme se alardeou quando da necessidade de defesa das medidas tomadas. Desse ponto de vista, aliás, não saímos do lugar, e chegamos a piorar. Nossa participação no bolo total do comércio internacional mundial não saiu de $0,7 \%$. Mas perdemos posições no ranking mundial de competitividade (caímos oito posições) e pioramos também num tipo de classificação que é indicativa da qualidade do que exportamos em termos de valor agregado: desde 1990, a participação do Brasil no ranking do valor agregado manufatureiro caiu de 2,9\% para $2,7 \%$. Só para se ter uma idéia do que isso significa, a Argentina, com tudo que passou, manteve sua participação em 0,9\% (Unctad, apud Belluzzo, 2005). Compare-se esse desempenho com o fato de que as despesas com pagamento de rendas de fatores derivados de investimentos em carteira da balança de serviços brasileira cresceram 25 vezes nos últimos 15 anos (de US\$432,5 milhões em 1990 para US $\$ 11,2$ bilhões em 1994). Esse tipo de despesa, que inclui lucros e dividendos de ações e juros de títulos de renda fixa, é típico da internacionalização financeira na qual vem se inserindo o Brasil com tanta disposição.

Isto posto, uma pergunta fica no ar. De que maneira tudo isso pôde ser feito? Já adiantamos o papel importante que o discurso neoliberal cumpriu, com suas promessas de desenvolvimento sustentado e modernização, no sentido de convencer um país recém-democratizado e cheio de planos de soberania e desenvolvimento a entrar numa era de austeridade para com os gastos stricto sensu sociais e, ao mesmo tempo, de concessão de prêmios à aplicação financeira 
e de entrega do patrimônio nacional. ${ }^{38}$ Já antecipamos também que um sentimento difuso de 'emergência econômica', no sentido de exceção, vem acompanhando a emergência do país como promissor mercado financeiro. Mas é no governo Lula que a decretação desse estado de emergência converte-se em necessidade.

Desde o início, para justificar o fato de estar adotando uma política econômica mais ortodoxa e conservadora que a de seu antecessor, o governo Lula utilizou o argumento (falacioso) ${ }^{39}$ de que essas medidas eram necessárias para retirar a economia brasileira da beira do abismo em que se encontrava. Em abril de 2003, todos os indicadores mais observados pelos 'mercados' já tinham sido revertidos: os indicadores de preço tinham se reduzido substancialmente e em alguns casos estavam até se tornando negativos, o risco-país caíra muito, a taxa de câmbio já tinha engatado a trajetória de queda e o C-Bond via crescer novamente seu preço. Mas, uma vez superado o momento inicial, as surpreendentes medidas primeiramente adotadas se perpetuaram, ao invés de serem alteradas. O governo teve de fazer a mágica de mostrar que o estado de emergência que guiou seus primeiros passos era o contrário de si mesmo, que tinha vindo para ficar, e com ele o regime de emergência então implantado. E ele foi bemsucedido nisso. Consideradas as expectativas então existentes sobre o novo governo, a política por ele implementada seria de difícil sustentação sem a decretação branca, porém firme, desse estado de exceção.

Mas o estado de exceção é justamente o oposto do estado de direito. Sob seus auspícios, uma espécie de vale-tudo toma o lugar do espaço marcado por regras, normas e direitos. Trata-se da suspensão da normalidade, da suspensão da 'racionalidade'. São puras medidas de força justificadas pelo estado de emergência e pela necessidade de 'salvar' a sociedade (neste caso, em que a emergência se tornou norma, trata-se de salvar a sociedade do eterno perigo da inflação e do inaceitável pecado da perda de credibilidade). A armação do estado de emergência econômico que presenciamos foi, assim, condição de possibilidade para que nossa relação com o centro passasse da dependência tecnológica típica da acumulação industrial à subserviência financeira típica do capitalismo rentista. No caso da etapa anterior, já nos estertores do modo fordista de regulação, seu momento final exigiu no Brasil um estado de exceção jurídico. No caso da etapa contemporânea, de dominância financeira, a normalidade jurídica exige o estado de emergência econômico. Nesse contexto, a ascensão ao governo federal de um partido historicamente de esquerda e historicamente 
adversário do estado de emergência, que se especializara em denunciar suas arbitrariedades, gerou a expectativa de uma 'volta à normalidade'. Tendo o governo adotado o caminho inverso ao esperado, só lhe restou agarrar-se de vez ao estado de emergência, decretando sua completa e total normalidade.

\section{Os Impasses do Projeto Neoliberal no Brasil: À GUISA DE CONCLUSÃO}

Como vimos, a inserção de nosso país no mundo globalizado pela via de sua transformação num mercado financeiro emergente tem nos reservado um papel melancólico na divisão internacional do trabalho, além dos efeitos deletérios que tem produzido para a economia nacional e para sua capacidade de produzir uma sociedade menos fracionada e barbarizada. A continuidade desse projeto só afundará o Brasil no mesmo atoleiro, metendo-o cada vez mais na armadilha que o impede de crescer e de praticar soberanamente políticas que revertam o secular quadro de desigualdade de renda e de descalabro patrimonial que tem marcado nossa história. Mas essa avaliação não é consensual, nem mesmo dentre o pensamento progressista.

Assim, antes de retomarmos a discussão sobre esses impasses, convém desfazer os equívocos que têm levado muitos a crer que o governo Lula estaria se constituindo numa alternativa ao neoliberalismo porque estaria conseguindo a mágica de fazer um governo de esquerda, supostamente forte nas políticas sociais, ao mesmo tempo que toca uma política econômica conservadora. ${ }^{40}$ Cabe então perguntar: no que consistiria de fato essa alternativa, particularmente levando-se em conta que se trata ou se trataria de um governo de esquerda? Consistiria na adoção de políticas que tivessem por meta a reversão do processo de fragmentação social que está em curso há quase duas décadas, graças justamente à ascensão das práticas neoliberais e do espírito neoliberal que as acompanha, espírito do cada um por si, do individualismo exacerbado, da demonização do Estado e dos movimentos sociais, da esterilização da força política dos sindicatos e assim por diante, espírito que a política econômica objetiva em transformações concretas enquanto a mídia encarrega-se de difundir como se se tratasse de uma coisa absolutamente natural. Em suma, para enfrentar esse movimento avassalador seria preciso investir em políticas que buscassem resultados objetivos, por exemplo, na redução da abissal desigualdade do país, mas que fizessem isso trazendo junto consigo uma revolução cultu- 
ral e de valores que proscrevesse como indignos e inaceitáveis os valores individualistas e puramente mercantilistas.

E o que faz o governo Lula? Todas as providências que ele toma vão justamente no sentido contrário. Nesse contexto, o que tem menos importância (ainda que seja também importante) é a política econômica em si mesma, ou seja, se amanhã ou depois o board do Banco Central resolver que é necessário baixar mais rapidamente os juros reais básicos e/ou a equipe do Ministério da Fazenda decidir que o superávit primário do governo pode ser menor do que $4,25 \%$ do PIB, nem por isso ele poderá ser considerado como não-neoliberal. Muito mais do que pela ortodoxia na condução da política macroeconômica, o governo Lula é neoliberal principalmente por três razões que estão interligadas, mas que analisaremos separadamente.

A primeira razão que faz do governo Lula um governo afinado com o neoliberalismo é justamente sua adesão sem peias ao processo de transformação do país em plataforma de valorização financeira internacional. A política ortodoxa escolhida pelo governo tem na credibilidade entre os mercados internacionais de capitais sua mais importante justificativa. Some-se a isso a elevada taxa real de juros que prevalece em nossa economia, a mais elevada do mundo (a segunda maior do mundo é a da Turquia, que é menor do que a metade da nossa); também somem-se as mudanças no mercado cambial com a conseqüente facilitação do envio de recursos ao exterior; some-se igualmente a nova Lei de Falências, que dá primazia aos créditos financeiros em relação aos créditos trabalhistas; e some-se por fim o projeto, que ainda não foi abandonado, muito ao contrário, de autonomia operacional do Banco Central, e perceber-se-á do que estamos falando.

A segunda razão que faz do governo Lula um governo neoliberal decorre de seu discurso de que só há uma política macroeconômica correta e cientificamente comprovada, que é a política de matiz ortodoxo levada à frente por sua equipe econômica desde o início do governo. ${ }^{41}$ Como do ponto de vista macroeconômico (leia-se de manipulação das variáveis da demanda agregada) não há escolha, sustenta-se que o crescimento virá do rearranjo das condições de oferta, ou seja, da política microeconômica, que consiste em 'melhorar o ambiente de negócios’. Essa melhora não passa apenas pela defesa dos direitos dos credores que a nova Lei de Falências consagra (e que a Lei de Responsabilidade Fiscal já apontava como inescapável) e pela desregulamentação do mercado de trabalho (leia-se perda de direitos), que a nova lei trabalhista deve pro- 
vocar; passa também pela abertura de novas e promissoras oportunidades de negócios como aquelas que serão trazidas pelas PPPs e pela privatização do Instituto de Resseguros do Brasil e aquelas já trazidas pelo crescimento do mercado privado de aposentadorias e pensões decorrente da reforma da previdência, isso tudo sem contar a pressão para que o setor financeiro privado possa, também ele, negociar com a parte gorda do mercado de créditos dirigidos.

A terceira mas não menos importante razão pela qual o governo Lula deve ser tachado de neoliberal encontra-se na assim chamada 'política social', que tem nas 'políticas compensatórias de renda' seu principal esteio. Deixando de lado as questões menores relativas a maior ou menor competência em sua condução, o fato é que, ao contrário do que se imagina, tais políticas sancionam as fraturas sociais em vez de promoverem a tão falada 'inclusão' (não à toa o criador e maior defensor da idéia da renda mínima é justamente Milton Friedman!). Fazer de projetos como o Fome Zero a base e o fundamento da política social do governo é ao mesmo tempo uma espécie de admissão de que, naquilo que importa, ou seja, na condução efetiva da vida material do país, a questão social está em último lugar (a política agrária, por exemplo, é pouco mais que uma farsa, não tendo até agora, ao contrário do que se esperava, enfrentado os grandes interesses latifundiários).

Como correm hoje outros tempos que não permitem mais que o primeiro mandatário do país diga, como pôde tranqüilamente dizer Fernando Henrique, que o modelo 'não é para os excluídos', o governo Lula faz o Fome Zero enquanto desmantela os direitos dos trabalhadores para facilitar os negócios e anda na contramão do solidarismo e da universalização dos bens públicos para tornar o país um investment grade. Assim, consideradas em seu conjunto, as três razões citadas não só não nos permitem de modo algum afirmar que o governo Lula promova qualquer tipo de enfrentamento, por diminuto que seja, ao neoliberalismo, como, ao contrário, nos obrigam a perceber o caráter completamente neoliberal de seu governo.

O governo Lula configurou-se, portanto, como a derradeira e mais uma vez frustrada esperança de uma refundação da sociedade brasileira, depois da devastação produzida pelos governos militares. Antes dessa frustração vieram a empolgação com as eleições diretas, a primeira eleição para presidente, o Plano Cruzado, a Constituinte e o Plano Real. Em todas essas oportunidades prevaleceu a idéia de que seria resgatado o processo de construção da nação, interrompido politicamente em 1964 e economicamente uma década depois. Nesse meio- 
tempo o capitalismo se transformou, assim como se alterou a relação do centro com a periferia. $\mathrm{O}$ alcance do estatuto de nação desenvolvida ficou mais distante e tão mais distante quanto mais profunda foi se configurando a submissão das elites dos países periféricos aos imperativos da acumulação financeira e aos acenos enganosos do discurso neoliberal.

No caso do Brasil essa submissão foi completa, tão completa que mesmo um governo pilotado por um partido operário nascido de baixo para cima, da árdua luta dos trabalhadores, foi incapaz de escapar dela. Trata-se de um impasse histórico para ninguém botar defeito. Para sair dessa situação, é preciso mais do que nunca força política e disposição de enfrentar interesses secularmente constituídos e que foram devidamente vitaminados nesses últimos 15 anos de escancarado e depois envergonhado neoliberalismo. Mas essa força não virá apenas de uma elite governante esclarecida. Sem mobilização social que empurre nessa direção, nosso destino será a manutenção desse modelo, e quanto mais o país persistir nele tanto mais difícil será retomar o projeto de fazer do Brasil um lugar condizente com suas condições e com suas potencialidades, uma nação generosa e soberana.

Quando escreveu a Crítica à Raz̃ão Dualista mais de três décadas atrás, Francisco de Oliveira vaticinou em seu final: "Nenhum determinismo ideológico pode aventurar-se a prever o futuro, mas parece muito evidente que ele está marcado pelos signos opostos do apartheid ou da revolução social" (Oliveira, 2003:119). Como não sobreveio a revolução social, instalou-se, como ele previu, o apartheid social que presenciamos. Para parodiá-lo, hoje, temos que escrever: nenhum determinismo ideológico pode aventurar-se a prever o futuro, mas parece muito evidente que, se não enfrentarmos o apartheid social, nos afundaremos na barbárie que já nos assombra e pereceremos como nação. 


\section{NOTAS}

${ }^{1}$ Também para os não-economistas vale observar, para demarcar melhor o terreno, que a teoria do valor-trabalho afirma basicamente que o valor das mercadorias é determinado, de maneira objetiva, pela quantidade de trabalho necessária para produzi-las, enquanto a teoria do valor-utilidade afirma que o valor das mercadorias é determinado, de forma subjetiva, pela utilidade que os agentes conferem a elas. No primeiro bloco estão a economia política inglesa de Smith e Ricardo, a teoria de Marx e escolas contemporâneas como os neoricardianos. No segundo bloco estão a teoria do equilíbrio geral, do francês Leon Walras, a teoria neoclássica, o monetarismo e sua variante moderna denominada economia novoclássica e, de modo geral, todo tipo de pensamento econômico de viés ortodoxo.

2 "Ao longo dos anos 30, a academia inglesa viu Hayek surgir inicialmente como uma estrela de primeira grandeza na constelação dos economistas e, posteriormente, terminar a década completamente apagado, ofuscado em grande medida pela avalanche keynesiana" (Andrade, 1997:176).

${ }^{3}$ José Luís Fiori (2004a), muito apropriadamente, interpreta esse acordo como o único exercício de 'governança global' da história capitalista.

${ }^{4}$ Utilizei o termo pela primeira vez em Paulani (2005a). Mais adiante retomarei algumas das considerações ali elaboradas sobre essa questão.

${ }^{5}$ De acordo com o mesmo Harvey, o próprio Hayek prescientemente viu que levaria um certo tempo para que as concepções neoliberais passassem a ser a corrente principal de pensamento. Segundo ele, teria de correr "pelo menos uma geração" até que isso acontecesse (Harvey, 2004:130).

${ }^{6} \mathrm{O}$ euromarket foi criado no final da década de 1950 . Apesar de interessar fundamentalmente à Inglaterra, que buscava com isso recuperar o importante papel de intermediária financeira internacional que desempenhara até antes da Primeira Grande Guerra, a iniciativa contou com o apoio americano. Na década de 1960, esses dois governos encorajaram seus bancos e suas grandes corporações a fazer suas operações nesse mercado (Fiori, 2004b; Jeffers, 2005).

${ }^{7}$ Não por acaso, ao longo desses anos foram muitas vezes os próprios Estados Unidos que, contrariando os princípios de Bretton Woods, ajudaram a promover desvalorizações nas taxas de câmbio de outros países, visando possibilitar seu crescimento (Serrano, 2004).

${ }^{8}$ Apesar do equilíbrio da balança comercial americana até então, seu balanço de pagamentos era deficitário por conta do resultado da balança de capitais. O papel de locomotiva do crescimento desempenhado pelos Estados Unidos exigia investimentos diretos elevados e volumosos empréstimos para os demais países, enquanto seu papel na geopolítica mundial, no contexto da Guerra Fria, obrigava o país a manter pesados gastos militares no exterior. Tudo isso contribuía para o resultado negativo da balança de capitais (Serrano, 2004). 
${ }^{9}$ Ao contrário dos déficits globais do balanço de pagamentos, que não ameaçavam as reservas em ouro dos Estados Unidos (justamente por causa da posição do dólar como moeda-chave), os déficits comerciais, principalmente se recorrentes, tinham efeitos deletérios sobre elas. Essa modalidade de déficit produzia aumento do passivo externo líquido do país, e esse tipo de obrigação, mesmo se denominada em dólar, era, pelas próprias regras de Bretton Woods, plenamente conversível em ouro pelos bancos centrais dos países credores (Serrano, 2004).

${ }^{10}$ A importância crescente do circuito offshore londrino implicava a multiplicação automática de eurodólares pelo jogo de empréstimos em cadeia entre os grandes bancos privados internacionais. A crise do petróleo, com o conseqüente aprofundamento da crise recessiva mundial, fez engordar ainda mais esses depósitos, que passaram de US\$ 7 bilhões, em 1963, para US $\$ 160$ bilhões dez anos depois e US $\$ 2,3$ trilhões vinte anos depois (Jeffers, 2005).

${ }^{11}$ Cabe esclarecer que, pelo menos no caso do Brasil, a opção feita pela ditadura militar não se restringiu à decisão de continuar a crescer, ainda que aumentando o grau de endividamento externo da economia brasileira. Na realidade, o governo Geisel decidiu continuar a crescer, a despeito da crise internacional, mas crescer de forma diferenciada, alterando a estrutura produtiva do país. O II PND, responsável pela manutenção de substantivas taxas de crescimento no período 1974-80 (ainda que inferiores àquelas observadas no período anterior, o período do 'milagre'), foi planejado não só para isso como também, principalmente, para completar a matriz interindustrial brasileira, cujas caselas relativas ao chamado Departamento I (insumos básicos e bens de capital) estavam, em sua grande maioria, ainda vazias. Buscava-se com isso reduzir a dependência externa do Brasil e tornar nossa economia menos vulnerável a choques de oferta, como o choque do petróleo.

12 'Modo de regulação' é um conceito criado pela chamada 'escola da regulação' no final dos anos 1970. Partindo do conceito marxista de modo de produção, os fundadores dessa escola, em sua maior parte franceses (Michael Aglietta, Andre Orleans, Robert Boyer etc.), julgaram que o modo de produção capitalista, ainda que seja movido sempre pela mesma lógica (a de valorizar o valor), funciona de modo distinto em cada etapa histórica. Assim, a reprodução do capital como relação social básica da sociedade moderna não se dá da mesma forma nos anos dourados e na fase posterior a eles. As instituições, as regras, os modos de cálculo e os procedimentos se alteram quando se passa de uma fase a outra, porque muda o 'regime de acumulação', o outro conceito básico dessa escola. Esse par de conceitos (a cada 'regime de acumulação' há um 'modo de regulação' que lhe corresponde) tem sido utilizado por muitos autores que hoje analisam a natureza das transformações experimentadas pelo capitalismo nessa sua fase contemporânea. Dentre essas análises damos destaque aqui àquela elaborada por François Chesnais $(1998,2005)$, outro economista francês, a qual em parte seguiremos.

${ }^{13}$ Não é à toa que Belluzzo (2004) afirma que, nessa fase da história capitalista, está em vigência uma espécie de 'ditadura dos credores'. 
${ }^{14}$ Esses empréstimos foram contratados, em sua maioria, com taxas de juros flexíveis, basicamente a Libor (inglesa) e a Prime (americana), que, naquele momento, se elevaram tal como as demais taxas.

${ }^{15} \mathrm{O}$ termo é de Keynes.

${ }^{16}$ Arantes (2004) fornece outro exemplo de trabalho precioso na mesma linha.

${ }^{17}$ Em Harvey (2004) há numerosos outros exemplos, colhidos em diferentes partes do planeta.

${ }^{18}$ Em trabalho de 1998, Francisco de Oliveira denominou esse mesmo espaço de 'antivalor'. Os trinta anos dourados foram pródigos em sua criação, e os anos subseqüentes em sua destruição.

${ }^{19}$ Tanto num como noutro caso - formas de relação capital-trabalho alternativas à contratação formal, ou 'com carteira assinada', como se diz no Brasil, e toyotismo - enquadram-se dentro do que Marx chamou de 'intensificação da exploração', modalidade de aumento do valor excedente não pago extraído da força de trabalho que não passa nem pelo aumento tradicional da produtividade (mais-valia relativa), nem pelo aumento da jornada de trabalho (mais-valia absoluta).

${ }^{20}$ Comparado ao período dos trinta anos gloriosos, quando a economia dos principais países industrializados (G7) crescia a taxas médias anuais superiores a $5 \%$, temos os seguintes resultados para a fase posterior: 1969-79, 3,6\%; 1979-90, 3\%; 1990-95, 2,5\%; 1995 $2000,1,9 \%$. Ao mesmo tempo, os salários reais, que entre 1960 e 1973 cresciam a uma taxa média anual de 7,7\% no Japão, 5,6\% nos 11 principais países europeus e 2,8\% nos Estados Unidos, crescem, entre 1990 e 2000, a uma taxa média anual de 0,5, 0,6 e 1,1\%, respectivamente (Brenner, 2003).

${ }^{21}$ Seguiremos, nesta questão, a análise de Pochmann (2001).

${ }^{22}$ Mesmo toda essa submissão do país receptor não garante que ele deixe de ser vítima, em curto espaço de tempo, de uma nova 'deslocalização'.

${ }^{23}$ Não é demais lembrar que as regiões periféricas acabam por atrair igualmente aquelas atividades que requerem extensivamente o uso de matérias-primas e energia e que são, portanto, não só insalubres como também poluidoras do ambiente.

${ }^{24}$ As informações estão em Belluzzo (2005:38-39).

${ }^{25}$ A base material dessa assim chamada 'nova economia' (Chesnais, 2001, faz uma avaliação do conteúdo ideológico do termo) é a terceira revolução industrial, que eclodiu nos anos 1970 e é marcada pela difusão em escala industrial da informática e das tecnologias avançadas de comunicação e pelo aprofundamento e diversificação de uso da pesquisa biogenética. A primeira revolução industrial começou na Inglaterra, na segunda metade do século XVIII, e teve como seus elementos característicos o tear mecânico, a máquina a vapor e o transporte ferroviário. A segunda, no começo do século XX, liderada pelos Estados Unidos, foi marcada pelas indústrias automobilística e de eletrodomésticos, pela indústria química, pela energia elétrica, pelo petróleo e pelo aço. 
26 'Alta inflação' foi o termo encontrado para designar fenômenos inflacionários como o do Brasil, em que os níveis gerais de preços nem se comportavam de forma 'civilizada' nem descambavam para a hiperinflação, permanecendo por longo tempo na casa dos dois dígitos ao mês.

${ }^{27}$ A esse respeito, ver Paulani (1997).

${ }^{28}$ A expressão é de Marx (1983) - vide capítulo XXIV do livro I de O Capital-, que considera a dívida pública como um típico exemplar de capital fictício.

${ }^{29}$ Retomamos, deste ponto em diante, considerações já feitas em Paulani (2004, 2005b) e Paulani \& Pato (2005).

${ }^{30}$ Por essa época, o presidente do Banco Central era Francisco Gros e o diretor da área externa era Armínio Fraga. O interessante é que, depois de tantas décadas de controle, o mercado permaneceu incrédulo quanto a essas mudanças até que, em novembro de 1993, já na gestão de Gustavo Franco na área externa do Banco Central, foi publicada uma 'cartilha' que escancarou para os agentes aquilo que eles estavam vendo sem acreditar. Não por acaso a tal cartilha ficou conhecida no mercado como 'Cartilha da sacanagem cambial'.

${ }^{31}$ As procuradoras da República Valquíria Nunes e Raquel Branquinho encaminharam à Justiça Federal, em dezembro de 2003, uma peça de acusação em que pediam a condenação, por crime de improbidade administrativa, de 15 executivos ligados ao Banco Central e ao Banco do Brasil. Elas argumentaram que essa transformação das CC5 foi feita de modo irregular, pois uma lei federal não pode ser regulamentada por um órgão de hierarquia constitucional inferior. Em outras palavras, o Congresso teria de ser ouvido... A mudança, porém, foi feita singelamente, mediante uma 'carta circular' do Banco Central (veja-se, a esse respeito, a excelente matéria de Raimundo Rodrigues Pereira, publicada na revista Reportagem de fevereiro de 2004).

${ }^{32}$ As informações foram retiradas de Fattorelli (2004).

${ }^{33}$ Cabe registrar que esse tipo de cálculo considera sempre como gasto previdenciário aquilo que não pode ser tomado como tal. A aposentadoria rural, empurrada goela abaixo dos conservadores pela Constituição de 1988, constitui efetivamente um grande programa de renda mínima, talvez o maior do continente, já que esse benefício passou a constituir-se num direito do trabalhador rural, tenha ele contribuído ou não, uma vez que seja, para o sistema previdenciário. Assim, os recursos despendidos com o pagamento desse tipo de benefício, apesar de integrarem o grupo de gastos relacionados à seguridade social, não podem ser entendidos como gastos previdenciários, aproximando-se mais dos gastos relativos a programas compensatórios de renda. Os especialistas no tema dizem, aliás, que é este o verdadeiro programa de renda mínima do Brasil (vide a respeito Marques \& Mendes, 2004).

${ }^{34}$ Mais uma ousadia do novo governo foi a imposição de contribuição aos inativos, que FHC tentara numerosas vezes sem conseguir, graças à persistente e feroz oposição a essa cobrança feita justamente pelo PT. 
${ }^{35}$ As dívidas trabalhistas que antes, sem limitação, encontravam-se no primeiro lugar da fila para o recebimento dos recursos da massa falida, continuam em primeiro lugar, só que agora restringidas pelo limite de $\mathrm{R} \$ 39$ mil. O que exceder esse limite vai para o último lugar. As dívidas financeiras garantidas por bens móveis ou imóveis, que ocupavam antes o terceiro lugar, passaram a ocupar o segundo lugar, à frente das dívidas tributárias. Não custa lembrar que, na carta de intenções ao FMI, assinada por Antônio Palocci e Henrique Meirelles em fevereiro de 2003, constava o compromisso de aprovar uma nova Lei de Falências que garantisse os direitos dos credores, ou seja, o recebimento pelo setor financeiro, em condições privilegiadas, das dívidas acumuladas pelas empresas falidas. Uma lei semelhante foi proposta pelo mesmo organismo à Argentina.

${ }^{36} \mathrm{Em}$ meados do corrente ano, perguntado sobre a necessidade de tal mudança, o atual presidente do BNDES, então ministro do Planejamento, Guido Mantega, respondeu tranqüilamente que se tratava de uma alteração necessária para preservar a sociedade da atuação de presidentes irresponsáveis e gastadores, que quisessem fazer o país crescer a qualquer custo.

${ }^{37}$ Em 1994 foi criado o Fundo Social de Emergência, denominado depois, mais adequadamente, Fundo de Estabilização Fiscal. Este fundo foi formado com $20 \%$ de todos os impostos e contribuições federais, tornados livres de vinculações. A partir de 2000, ele foi reformulado e passou a se chamar DRU (Desvinculação de Recursos da União), tendo sua prorrogação aprovada pelo Congresso Nacional até 2007.

${ }^{38}$ Em meados de 2000, um alto executivo da poderosa corporação espanhola Iberdrola afirmou que não entendia que razão podia ter o Brasil para vender empresas estatais bem estruturadas e lucrativas. Considerando que o personagem em questão é um executivo e deve entender do que fala, seu pronunciamento funciona como comprovação de que a gestão do Estado 'como se fosse um negócio', sendo contraditória por definição, produz, como já observamos, o resultado contrário ao observado nos negócios usuais - a dilapidação do Estado (e do país).

${ }^{39}$ Vide a respeito Paulani (2003).

${ }^{40}$ Retomo, a partir deste ponto, considerações já feitas em Paulani (2005c).

${ }^{41}$ Ainda que haja relação entre as práticas neoliberais e o pensamento ortodoxo, nós vimos, na primeira seção deste texto, como é falacioso esse argumento, uma vez que o neoliberalismo e sua coleção de práticas de política econômica derivam pura e simplesmente da crença nas supostas virtudes do mercado. 


\section{REFERÊNCIAS BIBLIOGRÁfICAS}

ANDERSON, P. Balanço do neoliberalismo. In: SADER, E. \& GENTILI, P. (Orgs.). Pós-Neoliberalismo: as políticas sociais e o Estado democrático. Rio de Janeiro: Paz e Terra, 1995. p.9-61.

ANDRADE, R. de. Hayek: a contraposição liberal. In: CARNEIRO, R. (Org.). Os Clássicos da Economia. São Paulo: Ática, 1997. p.56-89.

ARANTES, P. E. Um retorno à acumulação primitiva: a viagem redonda do capitalismo de acesso. Reportagem, 58:42-43, 20.jul.2004.

BELLUZZO, L. G. Ensaios sobre o Capitalismo no Século XX. São Paulo: Unesp; Campinas: Instituto de Economia da Unicamp, 2004.

BELLUZZO, L. G. Indústria: sinal amarelo. Carta Capital, 371, 2005.

BRENNER, R. O Boom e a Bolha: os Estados Unidos na economia global. Rio de Janeiro: Record, 2003.

CHESNAIS, F. A Mundialização do Capital. São Paulo: Xamã, 1996.

CHESNAIS, F. Introdução. In: CHESNAIS, F. (Org.). A Mundialização Financeira. São Paulo: Xamã, 1998. p.11-33.

CHESNAIS, F. 'Nova Economia': uma conjuntura específica da potência hegemônica no contexto da mundialização do capital. Revista da Sociedade Brasileira de Economia Politica, 9:53-85, dez.2001.

CHESNAIS, F. O capital portador de juros: acumulação, internacionalização, efeitos econômicos e políticos. In: CHESNAIS, F. (Org.). Finança Mundializada. São Paulo: Boitempo, 2005. p.35-67.

FATTORELLI, M. L. A grande sangria. Reportagem, 57, ano 5, jun.2004.

FIORI, J. L. Formação, expansão e limites do poder global. In: FIORI, J. L. (Org.). O Poder Americano. Petrópolis: Vozes, 2004a. p.11-64. (Zero à esquerda)

FIORI, José Luís. O poder global dos Estados Unidos: formação, expansão e limites. In: FIORI, J. L. (Org.). O Poder Americano. Petrópolis: Vozes, 2004b. p.67-110. (Zero à esquerda)

FRANCO, G. Inserção externa e desenvolvimento econômico. 1996. (Mimeo.)

HARVEY, D. A Condição Pós-Moderna. 9.ed. São Paulo: Edições Loyola, 2000.

HARVEY, D. O Novo Imperialismo. São Paulo: Edições Loyola, 2004.

HAYEK, F. Economics and knowledge. In: HAYEK, F. Individualism and Economic Order. Indiana: Gateway, 1948. p.85-104.

JEFFERS, E. A posição da Europa na valorização mundial dos capitais de aplicação financeira. In: CHESNAIS, F. \& JEFFERS, E. (Orgs.). Finança Mundializada. São Paulo: Boitempo, 2005. p.153-173. 
MARQUES, R. M. \& MENDES, Á. O governo Lula e a contra-reforma previdenciária. São Paulo em Perspectiva, 18(3):3-15, 2004.

MARX, K. O Capital. In: MARX, Karl. Karl Marx. São Paulo: Abril Cultural, 1983. (Os economistas)

OLIVEIRA, Francisco. Os Direitos do Antivalor. Petrópolis: Vozes, 1998. (Zero à esquerda)

OLIVEIRA, F. Crítica à Razão Dualista: o ornitorrinco. São Paulo: Boitempo, 2003.

PAULANI, L. M. Teoria da inflação inercial: um episódio singular na história da ciência econômica no Brasil? In: LOUREIRO, M. R. (Org.). 50 anos de Ciência Econômica no Brasil: pensamento, instituições e depoimentos. Petrópolis: Vozes, 1997. p.35-68.

PAULANI, L. M. Brasil delivery: a política econômica do governo Lula. Revista de Economia Política, 23(4):58-73, out./dez.2003.

PAULANI, L. M. Quando o medo vence a esperança: um balanço da política econômica do primeiro ano do governo Lula. Crítica Marxista, 19, out.2004.

PAULANI, L. M. Modernidade e Discurso Econômico. São Paulo: Boitempo, 2005a.

PAULANI, L. M. Sem esperança de ser país: o governo Lula 18 meses depois. In: SICSÚ, J.; PAULA, L. F. de \& MICHEL, R. (Orgs.). Novo Desenvolvimentismo: um projeto nacional de crescimento com eqüidade social. Barueri, Rio de Janeiro: Manole, Konrad Adenauer, 2005b. p.49-76.

PAULANI, L. M. O governo Lula é alternativa ao neoliberalismo? Revista da Sociedade Brasileira de Economia Politica, 16, jun.2005c.

PAULANI, L. M. \& PATO, C. G. Investimentos e servidão financeira: o Brasil do último quarto de século. In: PAULA, J. A. (Org.) Adeus ao Desenvolvimento. Belo Horizonte: Autêntica, 2005. p.36-75.

PEREIRA, R. R. Uma manipulação extraordinária. Reportagem, 53, ano 5, fev.2004.

POCHMANN, M. Globalização e emprego. In: ABRAMOVAY, R.; ARBIX, G. \& ZILBOVICIUS, M. (Orgs.) Razões e Ficções do Desenvolvimento. São Paulo: Edusp; Editora da Unesp, 2001.

SERRANO, F. Relações de poder e a política macroeconômica americana, de Bretton Woods ao padrão dólar flexível. In: SERRANO, F. (Org.). O Poder Americano. Petrópolis: Vozes, 2004. p.179-222. (Zero à esquerda) 


\section{Economia Brasileira Hoje:}

\section{SEUS PRINCIPAIS PROBLEMAS}

Márcio Pochmann

debate sobre os rumos da economia nacional tem sido muito difuso, combinando posições de analistas que vão desde a de inexperientes, mal-intencionados e românticos até a de vanguardistas e realistas. O que interessa aqui é destacar que o núcleo duro da discussão se assenta, de um lado, entre os chamados 'produtivistas', defensores da retomada sustentada do crescimento econômico, com maior participação do Estado e controle tanto do comércio externo como dos fluxos internacionais de recursos financeiros. Por serem críticos quanto às reais possibilidades brasileiras de inserção passiva e subordinada na globalização, acreditam mais na valorização das potencialidades do mercado interno decorrentes de uma ampla redistribuição da renda, sem desconsiderar, contudo, as possibilidades abertas pelos fluxos do comércio internacional. De outro lado, encontram-se os 'financistas', que se apóiam na elevada liquidez internacional para sustentar internamente a estabilidade monetária e a abertura comercial com desregulação financeira e desregulamentação do mercado de trabalho. Apostam também que os resultados do movimento de globalização das economias desde o final do século passado somente ocorrem a partir da liberalização da concorrência intercapitalista e da reformulação do papel do Estado (passagem da função empreendedora para a de regulatória e de focalização na área social).

Como se pode perceber, não há convergência nem nos diagnósticos nem nas propostas possíveis de condução das políticas macroeconômica e social. Em função disso, optou-se por dividir o presente estudo em duas partes, 
para além da apresentação e das considerações finais. Na primeira, busca-se destacar a situação geral de estagnação econômica que predomina no Brasil desde 1980, enquanto na segunda parte procura-se identificar as principais causas que imobilizam o dinamismo da economia nacional.

\section{Estagnação da Economia Nacional}

Depois de ter abandonado o seu projeto de industrialização nacional, ocorrido entre as décadas de 1930 e 1970, o Brasil passou a marcar passo no mesmo lugar. Três fatores contribuem para indicar a situação de estagnação da economia brasileira nos últimos 25 anos:

- a estabilidade da renda per capita em torno de valores não muito superiores aos da década de 1980;

- a permanência de baixas taxas de investimento;

- a desestruturação do mercado de trabalho.

A tendência de crescimento econômico medíocre no Brasil, principalmente se comparada à evolução da população brasileira (mesmo com taxas anuais decrescentes), resultou no estacionamento do Produto Interno Bruto (PIB) per capita em torno dos valores pouco acima dos de 1980.

Essa situação de semiparalisia do PIB per capita parece ser uma importante marca negativa da evolução da economia brasileira no período recente. Entre 1950 e 1980, por exemplo, a renda per capita chegou a crescer cerca de $4,0 \%$ ao ano, o que permitiu a quintuplicação, em apenas três décadas, da renda por habitante.

Se contrastada a posição da renda per capita brasileira com a de outras nações, as evidências da regressão são muito mais marcantes. Em 2003, por exemplo, a renda per capita do Brasil foi menor que 1/5 da dos Estados Unidos, enquanto em 1980 chegou a representar quase 1/3.

Além da estagnação da renda, a economia nacional tem mantido elevada instabilidade econômica, com forte e constante oscilação na produção e no emprego. O fato de o Brasil ter passado por dois períodos de recessão econômica (1981/83 e 1990/92), por quatro períodos de recuperação da produção (1984/ 86, 1993/95, 2000/01 e 2004/05) e ainda por três períodos de desaceleração das atividades (1987/89, 1996/99 e 2002/03) revela um contexto econômico de grave instabilidade nas decisões de produção e de investimento. 
Gráfico 1 - Evolução do índice do Produto Interno Bruto per capita* $(1950=$ 100,0\%). Brasil

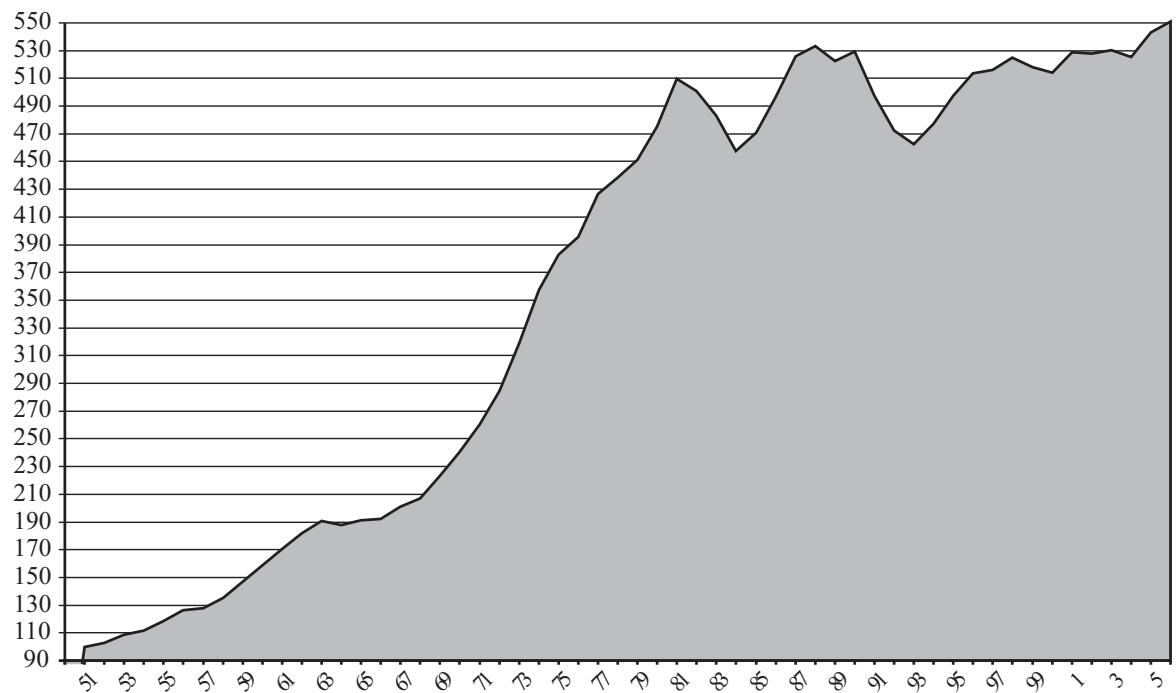

* Estimativa de 1,4\% para 2005.

Fonte: Bacen e FIBGE.

Nota-se a tendência de permanência de taxas de investimento como proporção do produto relativamente baixas, o que revela uma reduzida capacidade de recomposição e ampliação do parque produtivo nacional nos últimos 25 anos. Mesmo a recuperação do volume da produção entre 1993 e 1997, estimada em 22,5\% de expansão do PIB, não foi acompanhada pela evolução do investimento.

Ainda que a evolução na formação bruta de capital fixo desde 1950 reflita as distintas composições do Produto Interno Bruto, constata-se um período de elevação dos investimentos como proporção do PIB entre 1950 e 1975 e um segundo período de desaceleração dos investimentos desde então. Depois de atingir um quarto do PIB na metade da década de 1970, os investimentos apresentaram cinco curtos momentos de tentativa de reversão da tendência de desaceleração sem sucesso, como entre 1978 e 1979, entre 1985 e 1986, 1994 e 1997, 2000 e entre 2004 e 2005.

A recuperação econômica sem retomada dos investimentos reveste-se apenas e somente da ocupação da capacidade ociosa. Tão logo atinge o seu 
limite, inicia-se, mais uma vez, o movimento de desaceleração da produção, tendo em vista a pressão da demanda sobre a importação ou a elevação do nível do custo de vida.

Nessas circunstâncias, a política macroeconômica termina por induzir a elevação das taxas de juros como forma de conter o crédito e o consumo interno (queda na massa de rendimentos). Inibe-se, assim, a pressão por elevação dos preços internos, bem como se desafoga a demanda por produtos importados.

Mas isso tudo implica, direta ou indiretamente, conseqüências negativas para o comportamento do mercado de trabalho. Até 1980, por exemplo, o Brasil registrou um importante movimento rumo à estruturação do seu mercado de trabalho, diante da ampliação do universo de empregados assalariados, especialmente com carteira assinada, acompanhada tanto da redução dos postos de trabalho precários como da baixa presença do desemprego aberto.

Gráfico 2 - Evolução da taxa de formação bruta de capital fixo* (\% do PIB). Brasil $^{* *}$

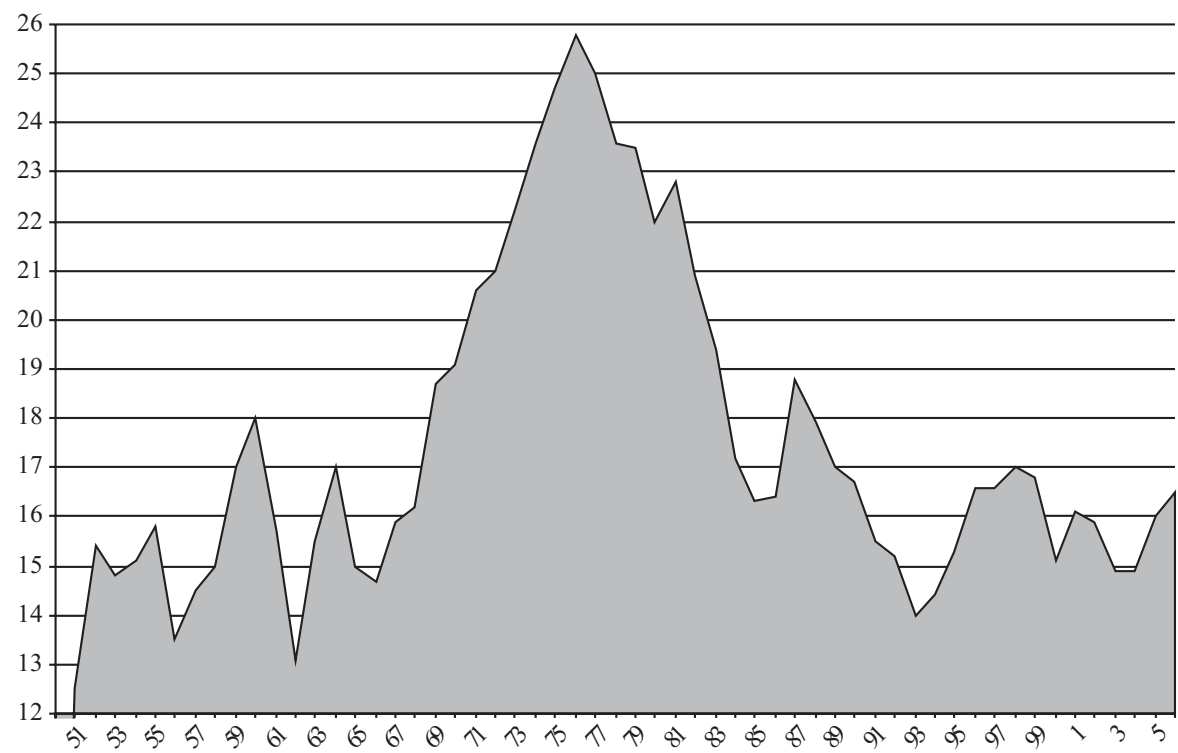

* Preços constantes de 1980.

** Estimativa para 2005.

Fonte: Bacen e FIBGE. 
A partir da década de 1980, contudo, o mercado de trabalho inverteu o sentido dos principais indicadores de comportamento. Com isso surgiu, então, o movimento de desestruturação do mercado de trabalho. Cresceu velozmente o desemprego aberto, cuja taxa mais do que quintuplicou nas duas últimas décadas, pois passou de 2,8\%, em 1980, para 15\%, em 2000. Da mesma forma, o aumento do desemprego veio acompanhado da diminuta geração de postos de trabalho, na maioria precária. No ano 2000, por exemplo, a taxa de precarização dos postos de trabalho ultrapassou os $40 \%$ do total da ocupação nacional. Vinte anos antes, em 1980, a precarização representava um a cada três trabalhadores ocupados.

Tabela 1 - Evolução da população economicamente ativa, da condição de ocupação e do desemprego. Brasil - 1940-2000

\begin{tabular}{|c|c|c|c|c|c|}
\hline Itens & 1940 & 1980 & 2000 & $\begin{array}{l}\text { Variação re } \\
1940 / 1980\end{array}$ & $\begin{array}{l}\text { ativa anual } \\
1980 / 2000\end{array}$ \\
\hline População total & $41.165,3$ & $119.002,3$ & $169.799,2$ & $2,7 \%$ & $1,8 \%$ \\
\hline PEA & $\begin{array}{r}15.751,0 \\
(100,0 \%)\end{array}$ & $\begin{array}{r}43.235,7 \\
(100,0 \%)\end{array}$ & $\begin{array}{r}76.158,5 \\
(100,0 \%)\end{array}$ & $2,6 \%$ & $2,9 \%$ \\
\hline PEA ocupada & 93,7 & $97,2 \%$ & $85,0 \%$ & $2,6 \%$ & $2,2 \%$ \\
\hline Empregador & $2,3 \%$ & $3,1 \%$ & $2,4 \%$ & $3,3 \%$ & $1,6 \%$ \\
\hline Conta própria & $29,8 \%$ & $22,1 \%$ & $19,1 \%$ & $1,8 \%$ & $2,1 \%$ \\
\hline $\begin{array}{l}\text { Sem } \\
\text { remuneração }\end{array}$ & $19,6 \%$ & $9,2 \%$ & $6,3 \%$ & $0,6 \%$ & $0,9 \%$ \\
\hline Assalariado & $42,0 \%$ & $62,8 \%$ & $57,2 \%$ & $3,6 \%$ & $2,4 \%$ \\
\hline - Com registro & $12,1 \%$ & $49,2 \%$ & $36,3 \%$ & $6,2 \%$ & $1,3 \%$ \\
\hline - Sem registro & $29,9 \%$ & $13,6 \%$ & $20,9 \%$ & $0,6 \%$ & $5,1 \%$ \\
\hline Desempregado & $6,3 \%$ & $2,8 \%$ & $15,0 \%$ & $0,5 \%$ & $11,9 \%$ \\
\hline $\begin{array}{l}\text { Taxa de } \\
\text { precarização* }\end{array}$ & $55,7 \%$ & $34,1 \%$ & $40,4 \%$ & $1,1 \%$ & $3,7 \%$ \\
\hline
\end{tabular}

* Conta própria, sem remuneração e desempregado.

Fonte: FIBGE (censos demográficos) - elaboração própria.

Também percebe-se a presença do desassalariamento, indicando a perda de importância relativa do emprego assalariado no total das ocupações. No ano de 1980, por exemplo, dois a cada três ocupados eram assalariados, enquanto em 2000 o assalariamento respondia por menos de 58\% dos ocupados. 
Além do processo de desassalariamento, observa-se uma modificação na natureza do emprego salarial. Até a década de 1970, por exemplo, crescia relativamente mais o emprego com registro formal, mas a partir dos anos 1980 aumentou a presença do emprego sem carteira assinada, o que significou a ausência dos tradicionais direitos sociais e trabalhistas.

Diante de tudo isso, cabe ressaltar que a presente fase de estagnação da economia nacional não permite compreendê-la como imutabilidade nas atividades produtivas. Pelo contrário, está em curso um novo modelo econômico, com baixa taxa de expansão produtiva, forte vinculação à financeirização da riqueza e à revalorização do setor primário exportador, conforme se apresenta a seguir.

\section{Novo Modelo Econômico Brasileiro}

A tendência de estagnação da economia brasileira resulta fundamentalmente da opção de políticas macroeconômicas realizadas pelas autoridades governamentais nos últimos 25 anos. Logo no início da década de 1980, a crise da dívida externa (1981/83), que resultou do contexto desfavorável da economia internacional (segundo choque do petróleo em 1979, elevação na taxa de juros internacionais entre 1979/83, recessão nas economias avançadas e ajuste nos bancos internacionais), levou à tomada de medidas duras pelo governo militar.

O objetivo principal foi o pagamento dos serviços da dívida externa por meio da elevação das exportações e da contenção das importações. Isso, contudo, colocou os primeiros obstáculos ao crescimento econômico sustentado, bem como potencializou o curso da alta taxa de inflação no Brasil.

Assim, a economia nacional viveu a sua primeira recessão desde o segundo pós-guerra, o que motivou que se tornasse parte da produção nacional mais competitiva no mercado internacional. Ao mesmo passo, o país contraiu substancialmente as suas importações devido à redução do tamanho do seu mercado interno.

Quando se retira a conta petróleo, o grau de abertura da economia na primeira metade da década de 1980 não ultrapassou os 3,5\% do PIB. Naquela oportunidade, foi um dos mais baixos do mundo. Quase como conseqüência, o Brasil consolidou um dos mais longos processos hiperinflacionários do século XX, a partir da recessão do início dos anos 1980. Foram cerca de 15 anos de predominância de supertaxas de inflação (1979/1994), acompanhados pelo fra- 
casso de quatro planos sucessivos de estabilização (planos Cruzado, Bresser, Verão e Collor).

Com o fim do regime militar em 1985, o programa de ajuste exportador estimulado pelo Fundo Monetário Internacional (FMI) foi interrompido. Entretanto, diante da ausência de ingressos voluntários de capitais internacionais, ao longo de praticamente toda a década de 1980, tornou-se muito difícil a construção de uma alternativa de crescimento econômico sustentado, capaz de combinar a estabilidade monetária com a renegociação da dívida externa em novas bases.

O Plano Cruzado, em 1986 - o mais bem elaborado plano de estabilização da década -, ruiu diante do esvaziamento das reservas internacionais e do forte poder dos exportadores brasileiros. Os planos de estabilização que o seguiram terminaram canalizando esforços orientados pelo atendimento dos interesses de banqueiros internacionais e, por conseqüência, dos exportadores e especuladores nacionais, o que contribuiu ainda mais para levar água ao moinho da hiperinflação.

No final dos anos 1980, com a nova mudança no contexto internacional (expansão das economias avançadas, grande liquidez internacional e reafirmação dos bancos e corporações transnacionais), surgiram condições mais favoráveis tanto para a renegociação da dívida externa quanto para a implementação de programas de estabilização monetária na América Latina. Uma nova orientação para as políticas macroeconômicas nacionais passou a ser defendida pelo FMI e pelo Banco Mundial a partir do Consenso de Washington, que expressou um conjunto de medidas de ajuste econômico (privatização, liberalização comercial e financeira, entre outras).

O Brasil, contudo, levaria ainda mais três anos para realizar uma renegociação, em novas bases, de sua dívida externa, demorando ainda cerca de quatro anos para concretizar um novo plano de estabilização monetária que representasse o rompimento com o processo hiperinflacionário. O Plano Real, em 1994, representou uma nova possibilidade de consolidação das medidas de combate à inflação, a partir das mudanças no contexto internacional e da adoção de intensos ajustes econômicos internos. Com isso, o país alcançou tardiamente a estabilidade monetária, tendo ainda hoje elevada a instabilidade macroeconômica. Em outras palavras, a combinação de altas taxas de juros com regime cambial inadequado, desregulação financeira, abertura comercial e desregulamentação do mercado de trabalho conformou um cenário nacional de forte dependência financeira e de ausência do crescimento econômico sustentado. 
Dessa forma, permaneceu uma forte oscilação no nível de atividade da produção (recuperação em 1994/95, 2000/01 e 2004/05 e desaceleração em 1996/99 e 2002/03). Entre 1994 e 1998, por exemplo, predominou como política macroeconômica a vigência de altas taxas de juros e de valorização da taxa de câmbio. O resultado disso foi o ingresso de recursos externos especulativos (ganhos fáceis no mercado financeiro) e produtivos (privatização do setor produtivo estatal e no setor privado) acompanhado da crescente oferta de bens e serviços que foram substituindo, em parte, a produção interna (aumento das importações e desaceleração das exportações).

Entretanto, a partir de 1999, diante da crise resultante das opções de política macroeconômica derivada do Consenso de Washington, o país abandonou o regime de taxa de câmbio fixo (desvalorização do real) e passou a adotar um programa mais profundo de ajuste nas finanças públicas, articulado a metas de inflação e de superávit fiscal. Inegavelmente, esse conjunto de medidas trouxe conseqüências para as atividades produtivas.

Deve-se destacar, por exemplo, que desde 1990 encontra-se em curso um novo projeto de inserção competitiva do Brasil na economia global. Por inserção competitiva da economia nacional entendem-se as ações governamentais direcionadas:

- à redução na diferenciação possível entre mercados interno e externo;

- à modernização de grandes empresas com fortes ligações no comércio internacional;

- à crescente vinculação econômica e financeira com o exterior e

- à passagem do Estado empreendedor para o Estado regulador e focalizador das ações sociais, com a privatização do setor produtivo estatal e a desnacionalização do setor produtivo.

As principais evidências do novo modelo econômico, em curso desde 1990, são:

- a alteração na composição da demanda agregada;

- a reinserção externa;

- a reestruturação das grandes empresas privadas;

- a reformulação do setor público e

- a financeirização da riqueza, conforme apresentadas a seguir. 


\section{Alteração nA COMPosição da demanda agregadA}

A revisão no papel do Estado na economia nacional (racionalização e descentralização do gasto e privatização do setor público estatal), a desregulação financeira (endividamento externo e maior dependência de ingressos financeiros) e econômica (fusão de grandes empresas produtivas e financeiras) e a estabilização monetária constituem as alterações marcantes na composição da demanda agregada no Brasil. Essas modificações não tenderam a se mostrar, até agora e por si só, suficientes para permitir a retomada sustentada do desenvolvimento socioeconômico, tampouco possibilitar a inversão da tendência de desestruturação do mercado de trabalho.

Gráfico 3 - Evolução dos índices do produto industrial, da exportação, da importação e da participação do total dos investimentos estrangeiros feitos no país em relação ao resto do mundo $(1980=100,0 \%)$. Brasil

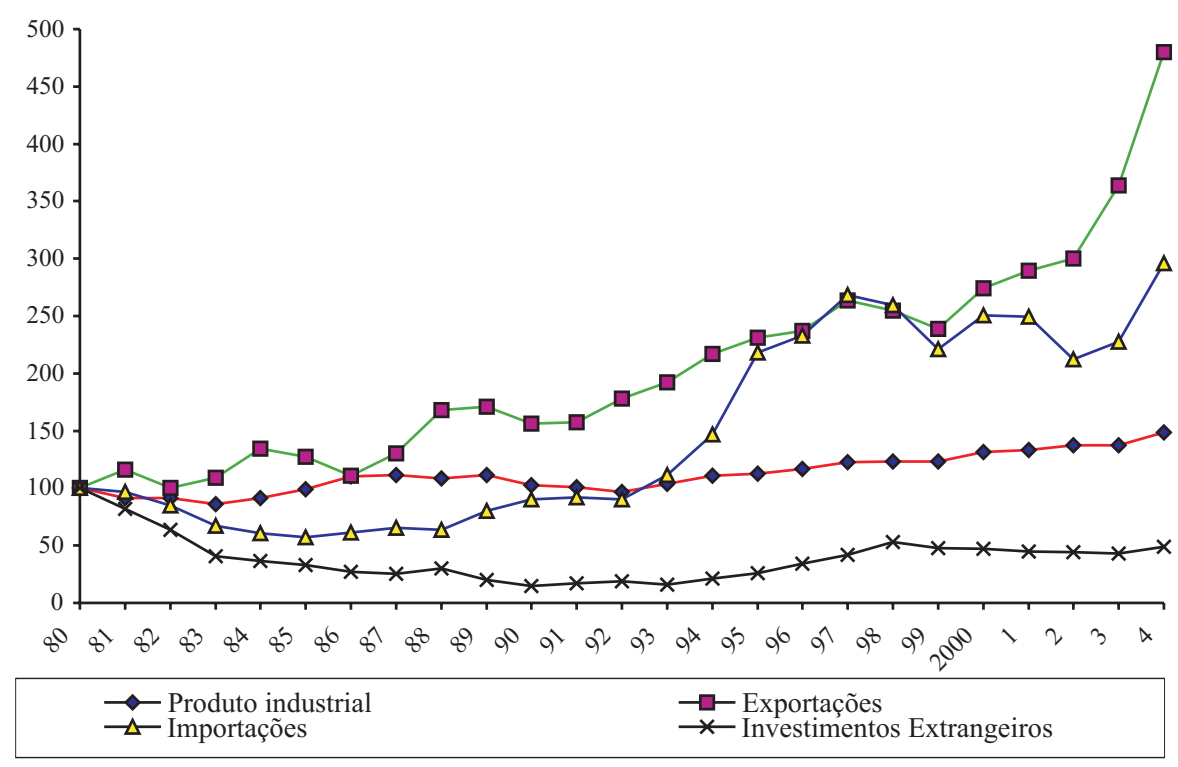

Fonte: Bacen, FIBGE e Unctad. 
Observa-se que a instabilidade da produção industrial nos últimos 25 anos no país foi acompanhada pela expansão das exportações entre 1985 e 1995 e a partir de 1999. E as importações, que entre 1980 e 1988 se mantiveram num patamar relativamente comprimido, apresentaram, entre 1992 e 1998, uma tendência de rápido crescimento. Em função disso, a produção industrial foi sendo, em parte, substituída por produtos importados. Ocorreu, em contrapartida, o avanço consistente da exportação de produtos primários, com baixo valor agregado e pequeno conteúdo tecnológico.

A estabilidade monetária aconteceu associada à maior oferta de produtos importados e ao ingresso de recursos externos. O PIB, com isso, sofreu uma nova recomposição. O setor secundário da economia perdeu participação relativa, enquanto o setor de serviços continuou elevando sua participação na

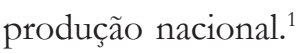

\section{REINSERÇÃo EXTERNA SUBORDINADA}

Na década de 1990, o Brasil inaugurou uma nova fase de reinserção externa, marcada pela abertura comercial, pela desregulamentação financeira e pela continuidade da integração regional (Mercosul). Essa situação, ao longo da década de 1980, se mostrou muito distinta do desempenho brasileiro no exterior, quando a crise da dívida externa levou ao fechamento da economia, como forma de geração de saldos comerciais favoráveis ao pagamento dos compromissos financeiros com os bancos internacionais.

Com a implementação do programa de inserção competitiva no mercado global, verificou-se a partir dos anos 1990 uma drástica mudança no comportamento geral da economia nacional. A desfavorável combinação entre câmbio valorizado, juros elevados e ampla abertura comercial ocorreu desacompanhada de políticas industrial ativa, comercial defensiva e social compensatória.

Não por acaso, o país constituiu um modelo econômico sem possibilidades efetivas de retomada do crescimento econômico sustentado. A estabilidade monetária alcançada tornou-se prisioneira do baixo e instável crescimento econômico. 
Gráfico 4 - Evolução da dívida externa, das reservas internacionais e do saldo comercial (em bilhões de US\$). Brasil

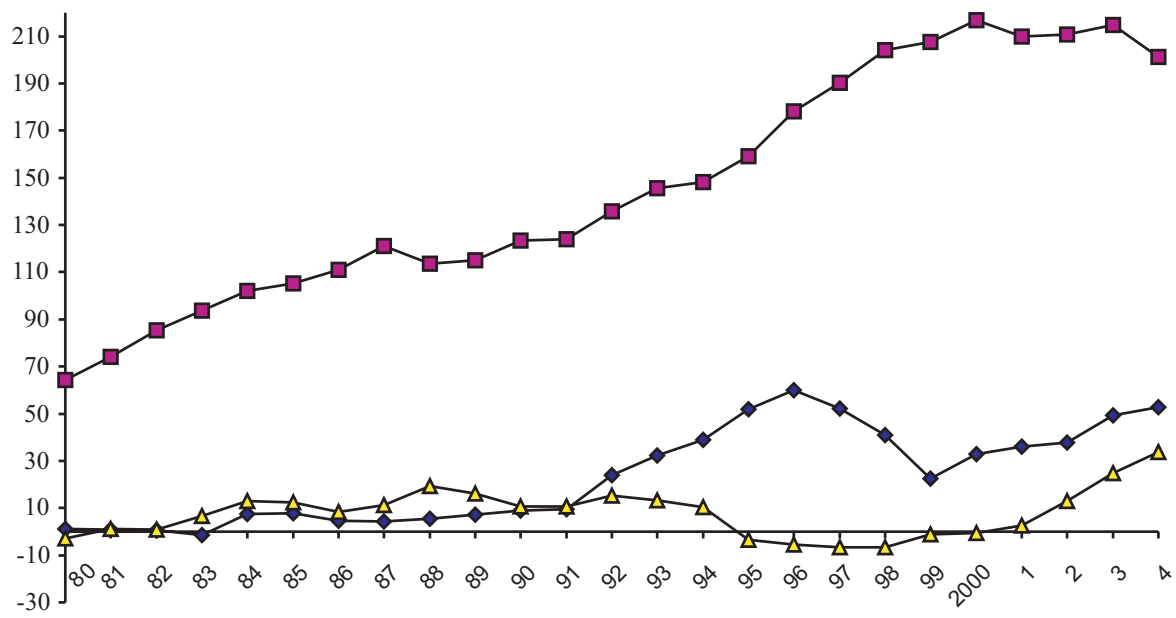

$\neg$ Reservas internacionais $\rightarrow-$ Dívida externa $\rightarrow-$ Saldo comercial

Fonte: Bacen e FIBGE.

A continuidade na elevação do endividamento externo, com adição considerável pós-1994, terminou sendo financiada pela absorção de parte da liquidez internacional. Por meio de taxas elevadas de juros, o país conseguiu atrair mais recursos externos, sendo uma parte composta de investimentos produtivos (na privatização do setor público e na compra de empresas nacionais) e outra parte - mais significativa - constituída de aplicações financeiras especulativas (recursos de curto prazo).

A existência de um ciclo favorável ao ingresso de recursos externos nos anos 1990, ao contrário da década de 1980, contribui também para o financiamento da balança comercial, que passou a operar com déficits entre 1995 e 2000. A abertura comercial, que se mostrou importante tanto para acirrar a competição intercapitalista no interior do mercado interno como para ajudar no combate ao processo hiperinflacionário, não se mostrou suficiente para alterar a posição brasileira na economia mundial. Em 1997, por exemplo, o Brasil participou com apenas $0,9 \%$ do comércio internacional, quando na década de 1980 chegou a representar mais de $1 \%$. 
Gráfico 5 - Evolução do custo do trabalho horário em dólar na indústria e da produtividade da mão-de-obra (em \%). Brasil

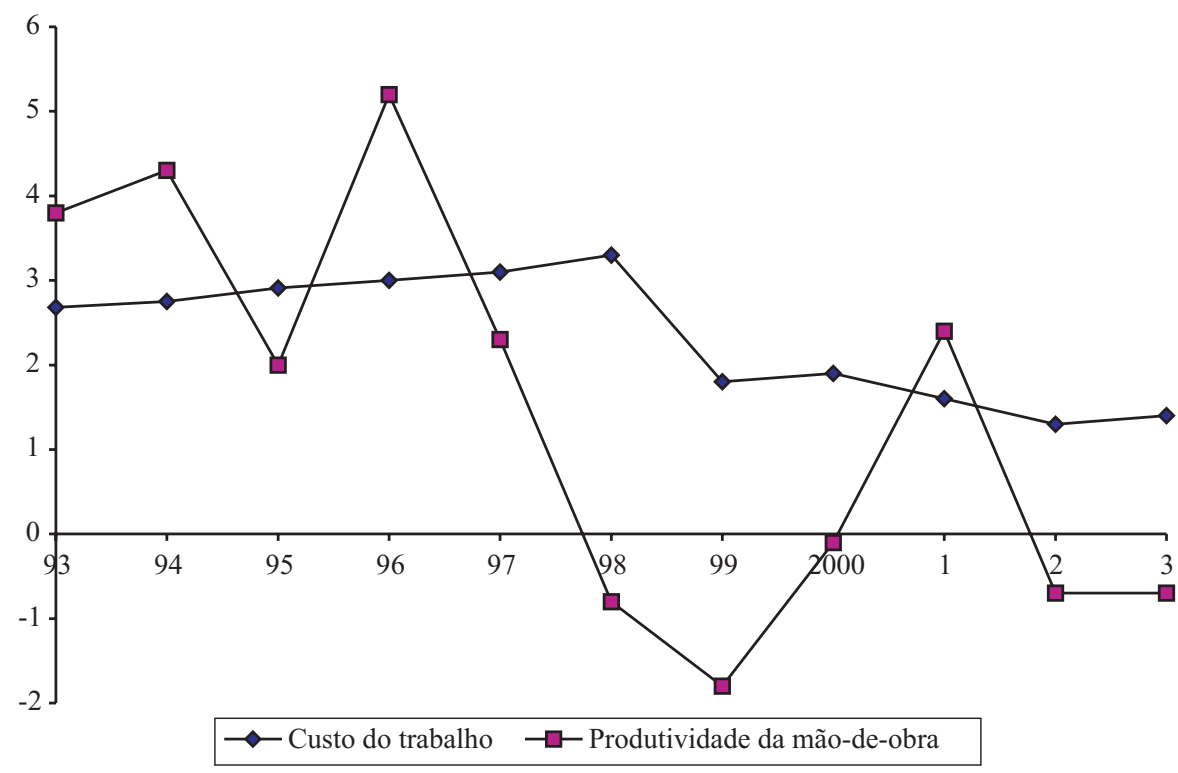

Fonte: BLS/USA e FIBGE.

Tal situação pôde se manter assim enquanto as finanças internacionais estavam favoráveis ao ingresso voluntário de recursos estrangeiros no país. Mas a partir da crise cambial de 1999, o país teve dificuldades adicionais para continuar financiando o seu déficit no balanço de pagamentos. Por conta disso, o Brasil fortaleceu o seu novo modelo econômico com uma mudança no regime cambial, abrindo a possibilidade de crescimento importante das exportações, mantidas em baixo nível suas importações. O acréscimo nas vendas externas se deu com base na forte progressão dos produtos primários, que passaram de 22,8\% das exportações, em 2000, para 29,5\%, em 2004.

A melhora na posição relativa do comércio externo não permitiu acompanhar - no mesmo ritmo - a expansão verificada em outras economias periféricas. Ademais, parte importante do diferencial de competição das exportações brasileiras veio estimulada pela redução do custo total da mão-de-obra, em meio ao quadro geral de baixa expansão da produtividade do trabalho.

$\mathrm{Na}$ maior parte das vezes, isso proporcionou a competitividade espúria, cuja expansão se sustentou na penalização da mão-de-obra e, sobretudo, na 
redução do peso dos salários na renda nacional. Em 1980, por exemplo, o rendimento do trabalho equivalia a $50 \%$ da renda nacional e, em 2003, representou menos de $36 \%$.

\section{REESTRUTURAÇÃo PERVERSA DAS EMPRESAS}

A implantação de um novo modelo econômico nos anos 1990 trouxe implicações significativas ao conjunto das empresas que atuam no Brasil. Em geral, notou-se o avanço do processo de reestruturação empresarial, induzido pelas mudanças na conduta das grandes empresas, como a adoção de novos programas de gestão da produção, de reorganização do trabalho e de inovação tecnológica.

A introdução de novos fundamentos competitivos foi marcada pelo aumento da produtividade do trabalho e pela busca de maior inserção externa, por meio da alteração nos preços relativos e da elevação dos investimentos, especificamente nas grandes empresas transnacionais. Mas esse movimento não foi geral nem homogêneo.

Na realidade, pôde-se observar tanto a destruição quanto a reestruturação de parte significativa do sistema produtivo industrial. ${ }^{2}$ Por conta disso, houve maior heterogeneidade na base econômica, com a modernização seletiva e contida de grandes empresas internacionalizadas - na ponta da cadeia produtiva - e o retraimento, fechamento e desnacionalização de outras, ao longo das cadeias produtivas. Também ganhou maior ênfase a informalização do processo produtivo.

Em grande medida, aprofundou-se a constituição de um novo mix na produção doméstica, levada adiante por intermédio da substituição de produtos intermediários e de bens de capital, produzidos internamente, por produtos importados, especialmente a partir dos anos 1990. ${ }^{3}$ Assim, parte da produção nacional foi sendo substituída por importados, o que fez com que o aumento da produção interna não atuasse positivamente, como no passado, sobre o nível de emprego, mas sim sobre as compras externas.

Entre as décadas de 1980 e 1990, por exemplo, somente as empresas com menos de dez empregados aumentaram continuamente a sua participação relativa no total das ocupações formais, pois as demais empresas terminaram adotando, de maneira generalizada, os processos de terceirização, redução de hierarquias funcionais, diminuição do núcleo duro de empregados, entre outros. 
Por conta disso, a participação dos empregados com menos de três anos de serviço numa mesma empresa em relação ao total da ocupação caiu de 60,5\% para 46,4\% entre os anos 1980 e 1990, enquanto os empregados com mais de cinco anos numa mesma empresa aumentaram sua participação relativa de $26,4 \%$ para $39 \%$.

Gráfico 6 - Distribuição dos empregos por tamanho de estabelecimentos (em $\%)$. Brasil

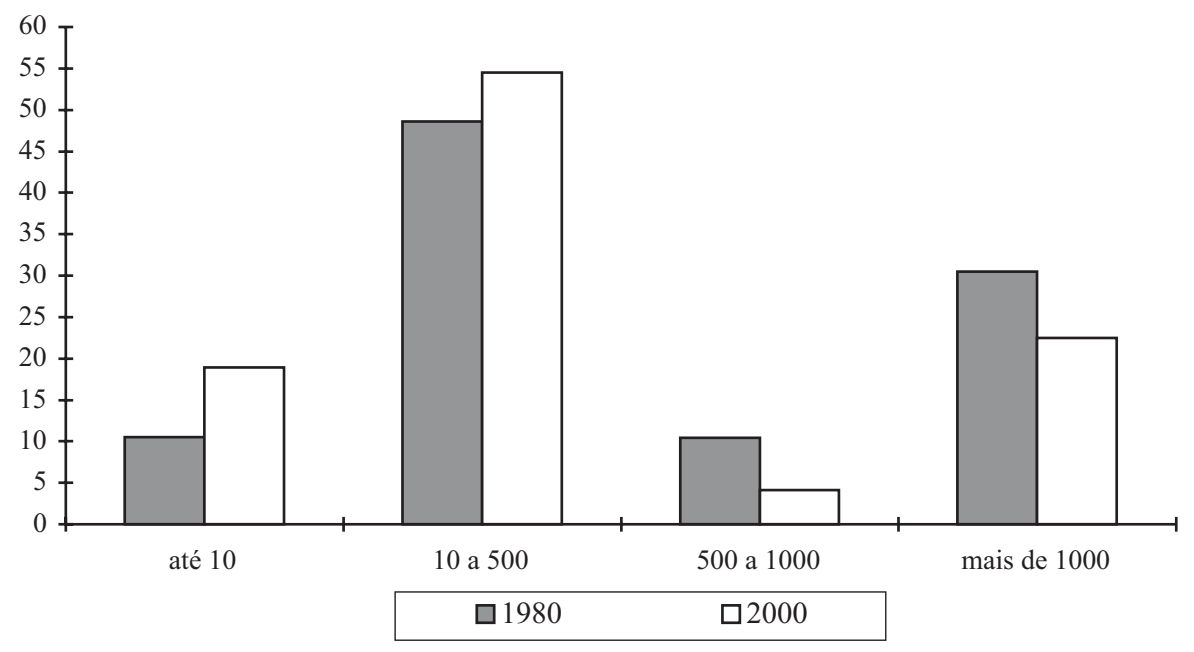

Fonte: MTb/Rais.

Simultaneamente, cresceu o peso do setor informal no interior das cadeias produtivas. Parte disso transcorreu por força do movimento mais geral de terceirização de parte do processo produtivo (especialmente nas atividadesmeio), da deslocalização de empresas e da adoção de novas formas de contratação da força de trabalho (cooperativas, pessoas jurídicas de empresas sem empregados, freelancers, estagiários, entre outros).

\section{REFORMULAÇÃo do SETOR PÚBLICO}

Durante a década de 1980, o setor público foi alvo de constantes ajustes, sobretudo no que diz respeito às despesas. Mas dói nos anos 1990 o fato de que as receitas tornaram-se crescentes, representando um acréscimo de mais de dez pontos percentuais do PIB de elevação na carga tributária. 
Depois de 1999, contudo, o Brasil passou a conviver com a meta de superávit primário nas contas públicas. Se, de um lado, o esforço fiscal do setor público assumiu maior centralidade na gestão da política macroeconômica, contribuindo para evitar a ampliação do endividamento público, de outro passou a constituir um verdadeiro entrave ao atendimento da dívida social no país.

A restrição orçamentária não apenas comprimiu a efetividade das políticas públicas em torno do enfrentamento das mazelas nacionais, sobretudo das desigualdades sociais, como também modificou a natureza do gasto governamental. Apesar da elevação na carga tributária, verificaram-se a contração e a alteração na composição do gasto público.

Com isso, tornou-se possível a geração de um significativo e recorrente superávit primário nas contas governamentais, capaz de atender parcialmente ao pagamento dos juros, bem como de evitar o maior endividamento líquido do setor público (\% do PIB). Como não poderia deixar de ser, o esforço fiscal terminou resultando em maior constrangimento do gasto público, o que tornou menos efetiva a política de universalização de direitos sociais.

Gráfico 7 - Comportamento das contas públicas no período de 1995 a 2004 (em \% do PIB). Brasil

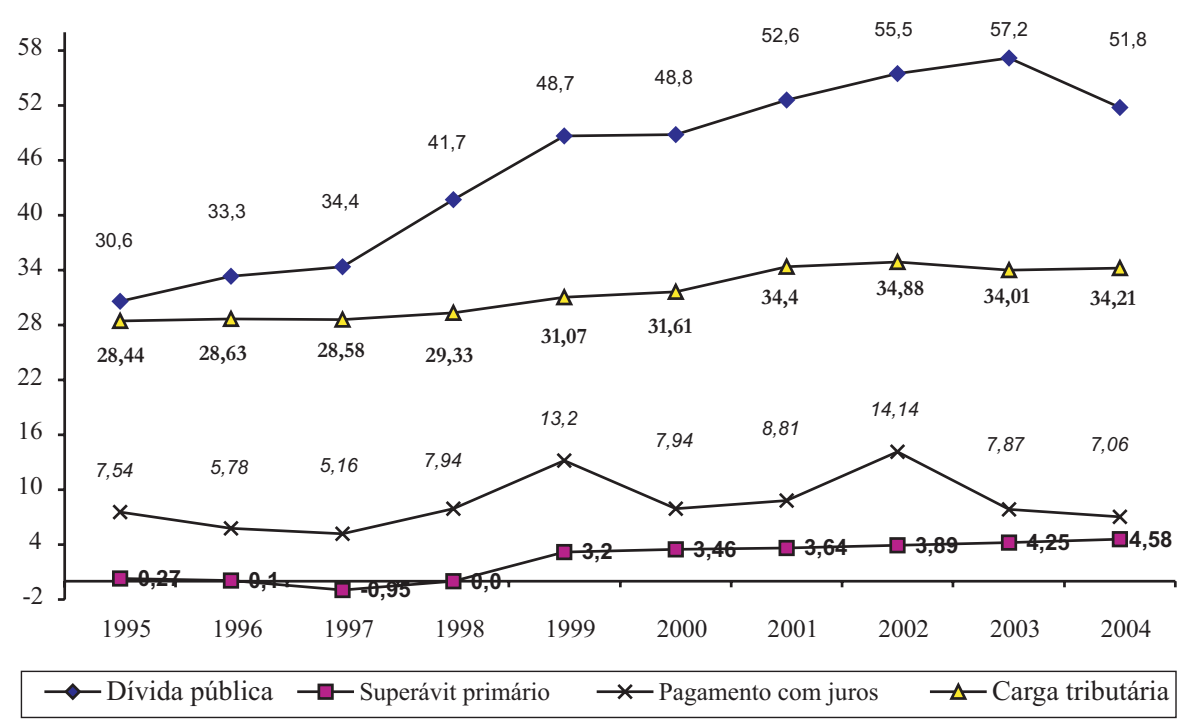

Fonte: IBGE/MF/Bacen (elaboração própria). 
Para agravar ainda mais o enfrentamento da desigualdade social no Brasil, observa-se que, no período mais recente (2001-2004), o quadro de restrições fiscais tendeu a se concentrar justamente no orçamento social do governo federal. Dessa forma, não apenas o contexto macroeconômico manifestou-se predominantemente anti-social como também os recursos públicos per capita direcionados à área social apresentaram um movimento de regressão em termos reais.

Entre 2001 e 2004, por exemplo, houve uma involução do orçamento social do governo federal, quando considerados o seu valor em termos reais (deflacionado pelo IGP-DI/FGV) e o comportamento populacional. Para o mesmo período de tempo, o orçamento social do governo federal acumulou uma redução real por habitante de quase $8,5 \%$.

De acordo com a metodologia de composição do orçamento social do governo federal, formulada pelo Ministério da Fazenda, ${ }^{4}$ quatro dos cinco itens apresentaram queda real per capita no período de 2001 a 2004. As maiores reduções no gasto social ocorreram na habitação e no saneamento $(-55,6 \%)$, sistema S $(31,1 \%)$ e benefícios aos servidores $(27,7 \%)$.

Tabela 2 - Orçamento social do governo federal por habitante e em valor real de 2001 (em R\$). Brasil

\begin{tabular}{|l|r|r|r|r|c|}
\hline \multicolumn{1}{|c|}{ Itens } & \multicolumn{1}{|c|}{2001} & \multicolumn{1}{c|}{2002} & \multicolumn{1}{c|}{2003} & \multicolumn{1}{c|}{2004} & $\begin{array}{c}\text { Variação } \\
2001 / 2004\end{array}$ \\
\hline Orçamento social total & $1.103,86$ & 904,65 & 970,04 & $1.012,17$ & $-8,31$ \\
\hline 1.Gasto social direto & 926,65 & 807,51 & 872,92 & 897,34 & $-3,16$ \\
\hline - Previdência social & 614,83 & 544,23 & 598,73 & 606,71 & $-1,32$ \\
\hline - Saúde & 122,90 & 106,59 & 108,60 & 114,65 & $-6,71$ \\
\hline - Assistência social & 49,34 & 45,50 & 52,64 & 58,55 & 18,67 \\
\hline - Educação e cultura & 52,06 & 41,02 & 45,40 & 47,01 & $-9,70$ \\
\hline - Proteção do trabalhador & 40,05 & 35,42 & 36,88 & 36,53 & $-8,79$ \\
\hline - Organização agrária & 7,72 & 6,53 & 5,38 & 8,59 & 11,27 \\
\hline - Habitação e saneamento & 11,00 & 4,98 & 3,53 & 4,89 & $-55,55$ \\
\hline - Benefícios ao servidor & 13,26 & 9,37 & 10,04 & 9,59 & $-27,68$ \\
\hline - Sistema S & 15,47 & 13,88 & 11,69 & 10,82 & $-30,06$ \\
\hline 2. Renúncia tributária & 78,00 & 71,36 & 72,60 & 64,25 & $-17,63$ \\
\hline 3. Empréstimo & 18,72 & 18,72 & 19,57 & 20,71 & 10,63 \\
\hline 4. Subsídio implícito & 1,62 & 1,51 & 2,08 & 1,38 & $-14,81$ \\
\hline 5. Ajuste patrimonial & 78,86 & 5,54 & 2,87 & 29,46 & $-62,64$ \\
\hline
\end{tabular}

Fonte: MF/SPE/Siafi (Deflator IGP-DI-FGV) (elaboração própria). 
De toda a composição do orçamento social do governo federal, somente o item empréstimo (10,6\%), identificado com o Programa de Geração de Emprego e Renda (Proger) e o Programa Nacional de Fortalecimento da Agricultura Familiar (Pronaf), registrou aumento real. No item gasto social direto, apenas a assistência social $(18,7 \%)$ teve crescimento real per capita no seu orçamento.

Em resumo, o orçamento social total do governo federal por habitante em 2004 equivaleu a 91,7\% do valor real do orçamento social do ano de 2001.

Ao se diferenciar o orçamento social do governo federal por períodos de governo, como os dois últimos anos de FHC (2001/02) e os dois primeiros anos de Lula (2003/04), pode-se analisar melhor o comportamento médio bianual do orçamento social do governo federal. No período de 2003/04, o orçamento social real per capita do governo federal foi 1,3\% inferior ao do período imediatamente anterior, equivalendo, em média, a 98,7\% dos dois últimos anos do governo FHC.

Tabela 3 - Orçamento social do governo federal por habitante em valor real de 2001 (média bianual em R\$). Brasil

\begin{tabular}{|l|r|r|r|}
\hline \multicolumn{1}{|c|}{ Itens } & $2001 / 02$ & $2003 / 04$ & Variação 2001/04 \\
\hline Orçamento social total & $1.004,25$ & 991,10 & $-1,31$ \\
\hline 1. Gasto social direto & 867,08 & 885,13 & 2,08 \\
\hline - Previdência social & 579,53 & 602,72 & 4,00 \\
\hline - Saúde & 114,74 & 111,62 & $-2,72$ \\
\hline - Assistência social & 47,42 & 55,60 & 17,25 \\
\hline - Educação e cultura & 46,54 & 46,20 & $-0,73$ \\
\hline - Proteção do trabalhador & 37,73 & 36,70 & $-2,73$ \\
\hline - Organização agrária & 7,12 & 6,98 & $-2,00$ \\
\hline - Habitação e saneamento & 7,99 & 4,21 & $-47,31$ \\
\hline - Benefícios ao servidor & 11,31 & 9,81 & $-13,26$ \\
\hline - Sistema S & 14,67 & 11,25 & $-23,31$ \\
\hline 2. Renúncia tributária & 74,68 & 68,42 & $-8,38$ \\
\hline 3. Empréstimo & 18,72 & 20,14 & 7,58 \\
\hline 4. Subsídio implícito & 1,56 & 1,73 & 10,90 \\
\hline 5. Ajuste patrimonial & 42,22 & 46,16 & $-61,72$ \\
\hline
\end{tabular}

Fonte: MF/SPE/Siafi (Deflator IGP-DI-FGV) (elaboração própria). 
Dos cinco itens que constituem a composição do orçamento social do governo federal, dois registram queda real per capita. Os itens ajuste patrimonial e renúncia fiscal tiveram redução orçamentária, enquanto os demais itens como gasto social direto, empréstimos e subsídios implícitos apresentaram maior orçamento no governo Lula em relação ao governo FHC.

Ainda com referência ao item gasto social direto, cabe destacar que o seu crescimento real per capita de 2,1\% durante os dois primeiros anos do governo Lula deveu-se fundamentalmente à expansão real dos recursos por habitante somente na previdência e na assistência social. Os demais componentes do gasto social apresentaram queda real se comparados os valores médios reais per capita nos dois primeiros anos do governo Lula com os dois últimos anos do governo FHC.

Novamente, as maiores reduções se concentraram na habitação e no saneamento, no sistema S e nos benefícios do servidor. Os componentes do gasto social direto, como educação e cultura e a organização agrária, foram os que menores reduções tiveram no mesmo período de tempo.

Conforme foi possível observar nas páginas anteriores, o Brasil caracteriza-se pela convivência simultânea do contexto macroeconômico anti-social com a regressão real per capita do orçamento social do governo federal. Diante dessa verdadeira combinação perversa, seria uma exceção à regra se o país viesse a registrar melhora na qualidade de vida, com redução sensível na desigualdade social.

O que surpreende realmente, nesse momento, é que os principais gestores das políticas públicas do governo federal parecem desconhecer a perversidade social que resulta tanto da condução das políticas macroeconômicas como do ajuste nas finanças governamentais, especialmente no que se refere à contenção real per capita do gasto social. Em vez de fazer considerações ligeiras e superficiais, muitas delas sem consistência real e que apontam para conclusões equivocadas, como a condenação do gasto social no Brasil, a equipe principal do Ministério da Fazenda deveria analisar melhor a sua própria contribuição ao aumento da dívida social, sobretudo no que diz respeito ao aprofundamento da desigualdade de renda.

De um lado, o contexto macroeconômico anti-social foi responsável, entre 2001 e 2004, pela redução relativa da participação do rendimento do trabalho na renda nacional. Estima-se que R $\$ 19,3$ bilhões deixaram de fazer 
parte da massa de rendimento do trabalho, em virtude da queda no rendimento médio dos ocupados e do maior desemprego.

Gráfico 8 - Transferência direta de renda do governo federal e massa de rendimento do trabalho entre 2001 e 2004 (em bilhões de $\mathrm{R} \$$ de 2004). Brasil

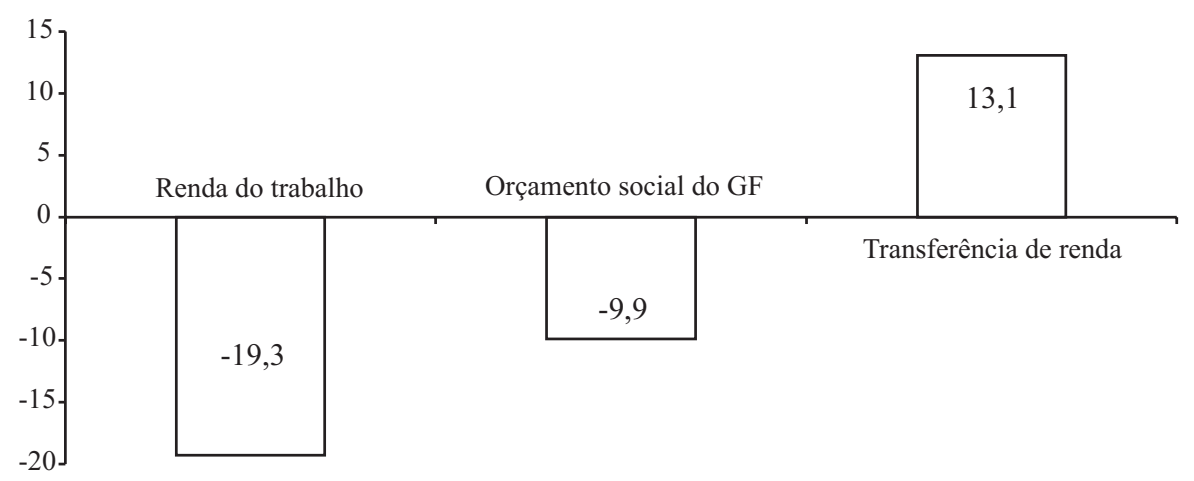

Fonte: IBGE/MTE/MF/SPE/Siafi (Deflator IGP-DI-FGV) (elaboração própria).

De outro lado, a queda real no orçamento social do governo federal correspondeu, no mesmo período, a uma perda estimada em $\mathrm{R} \$ 9,9$ bilhões. Mesmo com a expansão de $\mathrm{R} \$ 13,1$ bilhões relativa aos programas governamentais de transferência de renda (previdência e assistência social), o seu montante terminou sendo insuficiente para compensar o esvaziamento de $\mathrm{R} \$ 29,2$ bilhões da renda do trabalho dos ocupados e do orçamento social do governo federal.

O estranho disso tudo é que, salvo oscilações ocasionais, o endividamento do setor público tem permanecido ao redor dos 50\% do PIB. As opções das elites dirigentes do país por mais esforços voltados ao ajustamento das finanças (corte de gastos, desvinculação de receita, privatização e elevação de impostos) não se mostraram suficientes para a regressão do endividamento público nacional.

Em grande medida, percebe-se que o contínuo desajuste nas finanças públicas decorre do movimento mais geral de reestruturação patrimonial produzido pelos grandes empreendimentos do setor privado diante da ausência de perspectivas para a ampliação significativa do processo de acumulação do capital produtivo. Assim, constata-se a existência de um elemento de ordem estrutural na dinâmica capitalista atual que transforma o setor público no comandante da produção de uma nova riqueza financeirizada, apropriada 
privadamente na forma de direitos de propriedade dos títulos que carregam o endividamento público.

Dessa forma, para dar conta da contínua geração de direitos de propriedade dos resultados da acumulação financeira, tornou-se imperativa a implementação de um padrão de ajustamento regular nas finanças públicas e que termina atuando perversamente para a imensa maioria da população excluída do ciclo da financeirização. Isso porque o padrão de ajuste tem representado o aumento da carga tributária que afeta proporcionalmente os mais pobres, bem como a contenção do gasto social, a desvinculação das receitas fiscais sociais e a focalização das despesas em ações de natureza mais assistencial do que a universalização de bens e serviços públicos.

\section{CONSIDERAÇões FinaIS}

Conforme se procurou apresentar nas páginas anteriores, o novo modelo econômico brasileiro de inserção competitiva no mercado mundial não rompeu com a tendência de estagnação da economia nacional instalada a partir da década de 1980. Apesar da maior exposição da produção nacional à concorrência internacional e do sucesso da estabilidade monetária, o Brasil terminou por aumentar nos anos 1990 a dependência externa, bem como manteve a instabilidade macroeconômica associada à ausência do crescimento econômico sustentado.

A partir do Plano Real, as contas externas do país voltaram a ser extremamente desfavoráveis. Em certa medida, a dependência em relação ao exterior passou a se tornar tão complicada como durante o período da crise da dívida externa, no início da década de 1980, quando o país terminou realizando seis cartas de intenções com o FMI.

Diante do baixo desempenho da economia brasileira nos últimos 25 anos, o país consolidou o desempenho socioeconômico desfavorável, não apenas na renda per capita pouco acima da de 1980. Registram-se também taxas de investimentos relativamente baixas, bem como escassa geração de postos de trabalho e melhor distribuição da renda nacional.

Percebe-se hoje que a recuperação da economia pós-1992 se mostrou muito mais uma bolha de elevação do nível de atividade - financiada pelo endividamento e amparada pelas importações - do que a constituição de um 
novo ciclo de expansão produtiva. Ao contrário, ganhou relevância justamente o ciclo da financeirização da riqueza sustentada pelo Estado.

Ao mesmo tempo, o país passou a viver uma grave crise do emprego. $\mathrm{O}$ movimento de desestruturação do mercado de trabalho marcou o país durante as duas últimas décadas.

Além do desemprego em grande escala, tem importância o processo de desassalariamento, especialmente com a prevalência de postos de trabalho muito precários. Mesmo com a elevação da escolaridade da população, cresceu o desemprego entre os mais instruídos, assim como foram expandidos os postos de trabalho de baixos salários.

Desde 1999, com a mudança do regime cambial, a recuperação econômica foi acompanhada do crescimento do nível de emprego formal, o que indica o quanto a expansão da economia pode gerar postos adicionais de trabalho com carteira assinada. Deve-se considerar, no entanto, que 90\% dos novos empregos criados têm sido com remuneração de até dois salários mínimos mensais.

O novo modelo econômico proporciona ao Brasil participar com apenas $1,2 \%$ no comércio internacional, mas registra, em paralelo, a responsabilidade de $8 \%$ do desemprego aberto do mundial. Mesmo com a mudança no regime de câmbio fixo, o que favoreceu a retomada das exportações, o país passou a conviver com grave problema nas finanças públicas.

Ao lançar mão de um programa de ajuste nas finanças públicas, especialmente no que diz respeito às políticas sociais, a questão social tornou-se subordinada ao desempenho econômico. Mas o atual modelo econômico permite, no máximo, taxa relativamente reduzida de expansão do produto (com alto endividamento público e privado), geralmente financiada com recursos externos e transferências do setor público em nome do ciclo de financeirização da riqueza.

Diante disso, além do movimento de desestruturação do mercado de trabalho, combinado com uma nova onda de desemprego estrutural, configura-se um quadro socialmente explosivo, com parcela seleta da população ativa se mantendo cada vez menos incorporada aos empregos regulares.

A condução da política macroeconômica não atua, lamentavelmente, sobre o foco central do desajuste das finanças públicas. O regime cambial e os altos juros - responsáveis diretos pelo déficit público em maior monta - terminam não sendo atacados. Pelo contrário, mesmo sem o acordo com o FMI, o 
Brasil continua a se comprometer ainda mais em não atuar sobre eles. Conforme ocorreu nas crises financeiras de 1995 (mexicana), 1997 (asiática) e 1998/9 brasileira, o país seguiu perseguindo altas taxas de juros.

Além dos constantes cortes orçamentários, o governo brasileiro se comprometeu a elevar as receitas públicas para compensar os efeitos negativos da recente elevação das taxas de juros. Como a maior parcela do programa de ajuste do setor público recai sobre as despesas, torna-se decrescente o peso do funcionalismo no total da ocupação.

Em 2003, por exemplo, o Brasil possuía cerca de 8\% do total dos ocupados no setor público, enquanto em 1980 eram mais de 12\%. Lamentavelmente, as medidas de caráter compensatório ganharam maior importância, deixando em segundo plano o sistema de proteção social universal. Este, por sua vez, vem sendo afetado substancialmente diante do contingenciamento de recursos, decorrente do compromisso de geração do superávit fiscal.

Atualmente, cerca de $57 \%$ do superávit primário promovido nas contas públicas resulta do contingenciamento de recursos nas áreas sociais. Em virtude disso, o país termina sustentando o ciclo da financeirização da riqueza com base na redução do gasto social.

Os efeitos sociais disso são perversos para a população de um país com mais de $1 / 3$ vivendo na situação de extrema miséria. Sem a reversão do modelo econômico atual, as oportunidades de inclusão social tendem a ser diminutas, incapazes de permitir que o futuro seja de esperança e de justiça social.

\section{NOTAS}

${ }^{1}$ Para melhor acompanhamento da economia nacional durante a década de 1980, ver Carneiro (1993).

${ }^{2}$ Sobre a natureza do processo de reestruturação nacional, ver Mattoso \& Pochmann (1997).

${ }^{3}$ Para melhor entendimento, ver Baltar (1996), Cacciamalli et al. (1995), Delfim Netto (1996), Dieese (1994), Mattoso \& Baltar (1996).

${ }^{4}$ Não se entra no mérito da discussão sobre o que deve ser considerado como gasto social. A metodologia do Ministério da Fazenda é demasiadamente ampla, incorporando itens duvidosos quanto a sua natureza social. 


\section{REFERÊNCIAS BIBLIOGRÁfICAS}

BALTAR, P. Estagnação da economia, abertura e crise do emprego urbano no Brasil. Economia e Sociedade, 6, 1996.

CACCIAMALLI, M. et al. Crescimento econômico e geração de emprego. Planejamento e políticas públicas, 12, 1995.

CARNEIRO, R. Crise, ajustamento e estagnação. Economia e Sociedade, 2, 1993.

DELFIM NETTO, A. O desemprego neo-social. Brasília, 1996. (Mimeo.)

DIEESE. O desemprego e as políticas de emprego e renda. Pesquisa Dieese. Dieese, 10, 1994.

MATTOSO, J. \& BALTAR, P. Transformações estruturais e emprego nos anos 90. Cadernos do Cesit, 21, 1996.

MATTOSO, J. \& POCHMANN, M. Reestruturação on Desestruturação Produtiva no Brasil, 1997. 


\section{Papel Amassado: a perene recusa da SOBERANIA AO POVO BRASILEIRO}

Roberto Romano

$\mathrm{P}$ edem-me uma análise 'das teorias sobre a existência humana nas perspectivas da modernidade' e também as 'visões contemporâneas da subjetividade', tendo em vista a 'compreensão da sociedade brasileira'. A ambição é demasiada. Sou incompetente para efetivar tamanha proeza. Para seguir a solicitação do Seminário, apresentarei apenas as bases do controle da subjetividade no mundo moderno e o conseqüente abuso do poder absoluto que marcou o Estado brasileiro. Finalmente, farei alguns considerandos sobre a nossa vida social e política. Se não serei extensivo no trato de autores aos milhares e teorias idem, pretendo fornecer um guia seguro de trabalho. A vida política brasileira herdou, sem o saber, uma tradição repressiva que concentra nos governantes todas as políticas públicas, em especial a educação. E as retira da sociedade, dos grupos, dos movimentos, dos indivíduos. Trata-se de um velho problema jurídico e político: quem é o soberano? A democracia define-se como a forma de poder em que o povo é soberano. No Brasil, fingimos seguir essa forma de mando, mas na realidade ao nosso povo a soberania é recusada, sempre em proveito de oligarquias e dos que ocupam os três poderes formais do Estado. Sem direitos coletivos, detidos pelo povo soberano, é impossível até o presente manter direitos subjetivos. Se a ordem jurídica e política descura e desconhece a soberania popular, ninguém está em segurança. Este é o sentido das páginas seguintes.

O Brasil surge para a história da cultura e da política no âmbito da raison d'État. Pode-se dizer, com muitos analistas, que o Estado antecede a nossa própria existência social. É preciso refletir sobre esse ponto ligado a um outro 
de grande importância ainda em nossos dias. $\mathrm{Na}$ época moderna, a legitimidade do governante ainda reside no divino. ${ }^{1}$ Mas o poder laico afasta os conceitos teológico-políticos e assume a linguagem do interesse de Estado. Nesse processo, juristas e teólogos como Botero, em resposta ao desafio de Maquiavel, definem o uso legítimo dos poderes tendo como alvo manter e expandir os bens públicos (Botero, 1997). A razão de Estado incorpora o segredo para garantir o gabinete real, lugar onde não são admitidos os homens comuns. Aceito com reservas pela Igreja, o segredo é a marca dominante do Estado laico. Se o secretário (a origem do termo é marcada pela própria palavra do segredo) e o governante devem ocultar tudo o que for possível aos que não têm acesso aos gabinetes, eles, no entanto, devem descobrir tudo o que estiver para além das fronteiras de seu Estado e na mente e no coração dos dirigidos. O povo é excluído de todos os negócios estatais em proveito dos funcionários cujo ofício é a liturgia do poder. No cimento que determinou o Estado moderno, a burocracia e a concentração do mando nas mãos dos soberanos monarcas afastam o elemento popular de modo drástico. No Brasil é comum se dizer que o povo assistiu inerte aos grandes fatos políticos, da Independência à República. Este ponto alicerça a certeza de que entre nós os indivíduos (sobretudo os 'negativamente privilegiados', na expressão de Max Weber) não encontram respeitos, direitos, segurança, porque o coletivo não é visto pelos dominantes como soberano, mas apenas como ampla massa de manobras para a manutenção ou conquista do poder governamental ou estatal. Essa crônica tem raízes na gênese do autoritarismo moderno de Estado, que vigora pelo menos desde o século XIV na Europa e repercute até hoje no Brasil.

Vejamos como age o soberano desligado e contrário ao povo, no início do Estado moderno. Do gabinete onde se oculta, o príncipe nota o que para a maioria dos cidadãos passa despercebido. Esse ideal do governo que tudo enxerga, tudo ouve, tudo alcança é a base histórica dos atuais serviços de informação. O governante acumula segredos e deseja que os súditos sejam expostos a uma luz perene. Desse modo se estabelece a heterogeneidade entre governados e dirigentes. $\mathrm{Na}$ aurora dos tempos modernos,

a verdade do Estado é mentira para o súdito. Não existe mais espaço político homogêneo da verdade; o adágio é invertido: não mais fiat veritas et pereat mundus, mas fiat mundus et pereat veritas. As artes de governar acompanham e ampliam um movimento político profundo, o da ruptura radical (...) que separa o soberano dos governados. O lugar do segre- 
do como instituição política só é inteligível no horizonte desenhado por esta ruptura (...) à medida que se constitui o poder moderno. Segredo encontra sua origem no verbo latino secernere, que significa separar, apartar. (Chrétien-Goni, 1992:137)

No mesmo período, surgem as guerras de religião ocasionadas pela Reforma. As revoltas alemãs e francesas (a barbárie da Noite de São Bartolomeu) atingem a Inglaterra. Para espanto do clero e da aristocracia, as massas populares aprenderam a desobedecer às ordens dos príncipes. A antiga imagem do povo se exaspera. É conhecido o texto de Etienne de La Boétie (1976) O Discurso da Servidão Voluntária. Pouco se analisou o importante escrito do mesmo autor intitulado Mémoires de nos Troubles sur l'Édit de Janvier 1562 (La Boétie, 1917). Devido às lutas religiosas na Guiana, a corte envia o magistrado aos locais para analisar e depois escrever um texto com sugestões políticas e jurídicas. É clara a cautela de La Boétie em relação ao povo. Seria preciso impedir que o populacho tivesse ilusões de poder. Nas guerras religiosas que espalham 'um ódio e maldade quase universais entre os súditos do rei', o pior é que

o povo se acostuma a uma irreverência para com o magistrado e com o tempo aprende a desobedecer voluntariamente deixando-se conduzir pelas iscas da liberdade, ou melhor, licença, que é o mais doce e agradável veneno do mundo. Isto ocorre porque o elemento popular, tendo sabido que não é obrigado a obedecer ao príncipe natural no relativo à religião, faz péssimo uso dessa regra, a qual, por si mesma, não é má, e dela tira uma falsa conseqüência, a de que só é preciso obedecer aos superiores nas coisas boas por si mesmas, e se atribui o juízo sobre o que é bom ou ruim. Ele chega afinal à idéia de que não existe outra lei senão a sua consciência, ou seja, na maior parte, a persuasão de seu espírito e suas fantasias. (...) nada é mais justo nem mais conforme às leis do que a consciência de um homem religioso temente a Deus, probo e prudente, nada é mais louco, mais tolo e mais monstruoso do que a consciência e a superstição da massa indiscreta. (La Boétie, 1917:12)

E esse autor arremata:

O povo não tem meios de julgar, porque é desprovido do que fornece ou confirma um bom julgamento, as letras, os discursos e a experiência. Como não pode julgar, ele acredita em outrem. Ora, é comum que a multidão creia mais nas pessoas do que nas coisas, e que ela seja mais persuadida pela autoridade de quem fala do que pelas razões que se enuncia. (La Boétie, 1917:12) 
Gabriel Naudé fala do segredo e da desconfiança universal que obrigam o governante a se preservar "dos engodos, ruindades, surpresas desagradáveis" quando a massa está inquieta. Na crise de legitimidade é preciso cautela contra o animal de muitas cabeças, "vagabundo, errante, louco, embriagado, sem conduta, sem espírito nem julgamento... a turba e laia popular joguete dos agitadores: oradores, pregadores, falsos profetas, impostores, políticos astutos, sediciosos, rebeldes, despeitados, supersticiosos" (Consideracõoes Políticas sobre os Golpes de Estado (1639), apud Chrétien-Goni, 1992:141).

Assim, os teóricos da soberania popular não conseguiram audiência nas cortes e nos parlamentos aristocráticos. A universitas, communitas ou corpus, o povo reunido com majestade, toda essa constelação conceitual sofreu críticas desde os seus momentos iniciais. De outro lado, os que defenderam personalidade jurídica para o povo tomaram cuidado para que a soberania popular não fosse absorvida pelos representantes (Gierke, 1960). ${ }^{2}$

Já no final do século 13 a doutrina filosófica do Estado definiu o axioma de que o fundamento jurídico de todo governo reside na submissão voluntária e contratual das comunidades governadas. E foi declarado que, por um princípio de direito natural ao povo e apenas a ele, cabia colocar-se como chefe $(. .$.$) do poder estatal. Althusius afirma ser im-$ possível diminuir a soberania popular com base no contrato. (Gierke, 1974:81-83)

O povo seria o summus magistratus.

É contra a massa popular que os autores favoráveis à monarquia de direito divino se colocaram na Inglaterra do século XVII. As convulsões sociais e políticas que reuniram todos os prismas da vida capitalista triunfante ergueram a força popular traduzida em facções, dos Levellers aos Diggers, mesclando religião e imperativos democráticos. Quando a cabeça de Carlos I foi cortada, rompe-se o laço entre o corpo do rei e a divindade, toma novo sentido o princípio da accountability, exigência que segue a fé pública. John Milton expressa o princípio: "Se o rei ou magistrado provam ser infiéis aos seus compromissos, o povo é liberto de sua palavra”. Estas frases, postas em The Tenure of Kings and Magistrates, ${ }^{3}$ definem a nova legitimidade. O summus magistratus popular exige responsabilidade dos que agem em seu nome.

Milton retoma os democratas ingleses. Não por acaso tais enunciados foram recolhidos pelo inimigo da democracia no período, Thomas Edwards, 
num catálogo de 'heresias' que tinham a pena de morte como castigo. O erro dos democratas, diz Edward, reside em afirmar que

o poder supremo só pertence à Casa dos Comuns, porque só ela é escolhida pelo povo. O estado universal, o corpo do povo comum é o soberano terrestre, o senhor, rei e criador do rei, dos parlamentos, e todos os ministros da justiça. Majestade indeclinável e realidade residem de modo inerente no estado universal; e o rei, parlamentos etc. são as suas meras criaturas 'que devem prestar contas a eles, os quais deles dispõem a seu arbítrio; o povo pode pedir de volta e reassumir seu poder, questioná-los, e colocar outros em seu lugar'. (Edwards, 1977:16 destaques meus)

Thomas Edwards era um acadêmico de primeira plana e seus enunciados baseiam-se em fontes (sobretudo delações) e documentos. Se consultarmos historiadores da política inglesa no período, confirma-se a veracidade dos enunciados atribuídos por Edwards aos democratas (Hill, 1961 e 1965, sobretudo).

As teses democráticas inglesas repercutiram pela Europa inteira a partir daquele período. As Luzes francesas foram uma imensa tradução para o continente do pensamento produzido na Inglaterra desde o século XVI (Lutaud, 1973, 1978).

Não existe verdadeiro soberano a não ser a nação; não pode existir verdadeiro legislador, a não ser o povo; é raro que o povo se submeta sinceramente a leis impostas; ele as amará, as respeitará, obedecerá, as defenderá como sua obra própria se é delas o autor. (...) A primeira linha de um código bem feito deve ligar o soberano; ele deve começar assim: "Nós, o povo (início da Constituição norte-americana: We the People... [observação minha] $)^{4}$ e nós, soberano desse povo, juramos conjuntamente essas leis pelas quais 'seremos igualmente julgados'; e se ocorrer a nós, soberano, a intenção de mudá-las ou infringi-las, como inimigo de nosso povo, é justo que o povo seja desligado do juramento de fidelidade, que ele nos processe, nos deponha e mesmo nos condene à morte se o caso exige; esta é a primeira lei de nosso código. Desgraça ao soberano que despreza a lei, desgraça ao povo que suporta o desprezo em relação à lei". ${ }^{5}$

Robert Derathé registra que essa tese, com fortes conseqüências na feitura das leis, não existe nos países que hoje se julgam democráticos. Neles, "é raro que uma lei possa ser votada sem o assentimento do governo". Como educar a cidadania para que ela exerça o poder soberano, sem cair nas mãos dos dema- 
gogos? Apenas depois de 1791, por exemplo, Robespierre assumiu a soberania popular. No discurso 'Sobre a Constituição' (10/05/1793), ele toca a aporia ainda hoje irresolvida: "Dar ao governo a força necessária para que os cidadãos respeitem sempre os direitos dos cidadãos; e fazer isto de tal modo que o governo nunca possa violar os mesmos direitos." O governo, continua, "é instituído para fazer a vontade geral respeitada. Mas os governantes possuem uma vontade particular: e toda vontade particular tenta dominar a outra". Qualquer constituição deveria "defender a liberdade pública e individual contra o próprio governo". A solidez de uma Constituição se baseia "na bondade dos costumes, no conhecimento e no sentido profundo dos sagrados direitos do homem". Tangidos pelas massas, os jacobinos encaram o problema do governo comum e suas diferenças com o governo revolucionário. O governo revolucionário extrai legitimidade da "mais santa dentre as leis, a salvação do povo", e da necessidade. Governo revolucionário não significa "anarquia nem desordem. O seu fim é, pelo contrário, reprimir as duas coisas, para conduzir ao domínio das leis. (...) quanto maior o seu poder, quanto mais sua ação é livre e rápida, tanto mais é necessária a boa-fé para dirigi-lo". A mudança de 'soberania popular' para 'ditadura' é clara. A última salva o povo. ${ }^{6}$

E se os ditadores usufruírem o poder para si apenas? Na convenção jacobina, o governo, para 'instituir' a República, torna-se 'superior' à população. Mas os sans culotte, nas Assembléias Populares, insistiam na idéia e na prática da soberania do povo e na demissão sumária de deputados ('mandatários'), juízes e demais servidores públicos. Em $1^{\circ}$ de setembro de 1792, a seção Poissonière declara: "considerando que o povo soberano tem o direito de prescrever aos seus mandatários a via a ser seguida para agir conforme a sua vontade", os nomes dos deputados deveriam ser discutidos, aprovados ou reprovados pelas Assembléias primárias. A Assembléia-Geral do Marché-des-Innocents decide em 25 de agosto de 1792 que os deputados serão demissíveis por vontade de seu departamento, bem como "todos os funcionários públicos".

Os enciclopedistas e seus discípulos, como Condorcet, tinham se preocupado com a formação intelectual das massas populares, conditio sine qua non da ordem democrática moderna. Democracia exige eleições. Mas estas podem deseducar o povo, e os escrutínios trazem respostas incertas ou enganosas, perigo pressentido por Condorcet. Mesmo no Estado democrático

o poder se imiscui na operação eleitoral e a influencia: ele deseja demais uma 'representação' favorável. E três 'imagens' são misturadas nas elei- 
ções: a real, se a palavra tem sentido, a normativa ou potencial, porque se trata de conseguir uma direção no futuro, e a desejada e querida, porque os manipuladores tendem a se perenizar nos cargos e tentam desregulamentar os indicadores. (...) os modos de escrutínio contam mais do que o resultado final, pois ele depende deles. (Dagognet, 1984:186 e ss)

O rei, na instauração do Estado, foi conduzido ao segredo. O soberano popular segue o mesmo rumo quando sua prerrogativa se manifesta na hora do voto. Ali, supostamente, reina o segredo. Todos conhecem a passagem de Montesquieu no Espírito das Leis, mas a cito:

A lei que fixa a maneira de conceder os bilhetes dos sufrágios é ainda uma lei fundamental na democracia. É uma grande questão se os votos devem ser públicos ou secretos. Cícero escreve que as leis que os tornaram secretos nos últimos tempos da república foram uma das grandes causas de sua queda. (...) Sem dúvida, quando o povo vota, o voto deve ser público e deve ser visto como lei fundamental da democracia. É preciso que o povinho (petit peuple) seja esclarecido pelos principais e contido pela gravidade de certos personagens. (Montesquieu, 1951:243, livro II, capítulo II)

Rousseau comenta o segredo deseducador do voto. Nas antigas repúblicas virtuosas,

cada um tinha vergonha de dar publicamente seu sufrágio a uma opinião injusta ou assunto indigno, mas quando o povo se corrompeu e seu voto foi comprado, foi conveniente que o segredo fosse instituído para conter os compradores pela desconfiança e fornecer aos salafrários (fripons) o meio de não serem traidores. (Rousseau, 1971:570, t.2)

Condorcet foi contrário ao voto secreto. Mas seus motivos diferem dos enunciados por Montesquieu e Rousseau. É autor de projetos de educação popular e conhece os problemas matemáticos suscitados nas eleições. Dos votos tudo pode sair, inclusive servidão. Ele mostra como o voto simples (sim e não) traz o arbitrário quando se trata de decidir entre diferentes programas ou pelo menos três candidatos. Este é o sentido do 'paradoxo de Condorcet', atualização do 'paradoxo de Bordas'. Com esse escrutínio tem-se maior probabilidade de transformar a maioria em minoria e vice-versa. "É possível, se houver apenas três candidatos, que um entre eles tenha mais votos do que os dois outros e que, entretanto, um desses últimos, o que teve menor número de votos, seja olhado pela pluralidade como superior a cada um dos seus concor- 
rentes” (Dagognet, 1984:186). Após demorada análise matemática, ele enuncia que, numa eleição assim, o mais contestado pode ser eleito, enquanto o melhor, na hipótese de um escrutínio plurinominal, eliminado (Dagognet, 1984:192 e ss.). O paradoxo de Condorcet é estudado ainda em nossos dias. ${ }^{7}$

As multidões não foram ensinadas ao voto segundo o cálculo das probabilidades. No Termidor, a massa popular perdeu a soberania e foi substituída pelos proprietários, seguindo a receita de Boissy d'Anglas em discurso de 5 Messidor, ano 3: "Devemos ser governados pelos melhores. (...) ora, com poucas exceções, só podemos encontrar semelhantes homens entre os que, possuindo uma propriedade, são apegados ao país que a contém, às leis que a protegem, à tranqüilidade que a conserva." Para o termidoriano, a lei não é máxima derivada do nexo entre princípios e situação. Somem as exigências do povo, a accountability e a destituição do governante. Com Napoleão e sua ditadura, imenso maquinismo operado pelo segredo, foram dadas as condições para o fim da doutrina sobre a soberania popular direta.

Depois de examinadas as teses sobre o poder moderno, do absolutismo religioso ao laico, com Hobbes e pensadores que o sucederam no século XVIII, notemos que naquelas doutrinas o juízo subjetivo individual foi afastado, para que reinasse a ordem do poder público. Com a Revolução Inglesa do século XVII e com as revoluções Norte-Americana e Francesa do século XVIII, ocorreu o apelo à soberania popular e aos direitos dos indivíduos e grupos. Mas logo os partidários daqueles experimentos democráticos foram vencidos e reprimidos no Estado e na sociedade moderna. Após a Revolução Francesa ocorreu o Termidor, um retrocesso no que se relaciona com os direitos cidadãos. Semelhante retrocesso possibilitou a ditadura de Napoleão e, no que diz respeito ao Brasil, possibilitou a instauração de um poder reacionário, oposto às conquistas revolucionárias. O Poder Moderador é o núcleo a partir do qual a democracia foi censurada e reprimida em nosso país. Mas sigamos por partes.

O pensamento conservador ajudou o Brasil a representar uma entidade estatal independente mas contrária à democracia durante os séculos XIX e $\mathrm{XX}$. Os nossos governantes receberam muita força do pensamento que ajudou a expulsar da cena pública os direitos conquistados nas revoluções dos séculos XVII e XVIII. No Brasil se praticou a recusa da soberania popular desde antes da Independência. Mas depois dela também continuamos alheios aos direitos do povo soberano. Seguiram nossos governantes lições como a de Donoso Cortés: 
A soberania de direito é una e indivisível. Se ela é própria do homem, ela não pertence a Deus. Se localizada na sociedade, não existe no céu. A soberania popular é ateísmo, e se o ateísmo pode introduzir-se na filosofia sem transformar o mundo, ele não pode introduzir-se na sociedade sem feri-la com a paralisação e a morte. O soberano possui a onipotência social. Todos os direitos são seus, porque se houvesse um só direito que não estivesse nele, não seria onipotente e, não o sendo, não seria soberano. Pela mesma razão, todas as obrigações estão fora dele, porque, se ele tivesse alguma obrigação a cumprir, seria súdito. 'Soberano é o que manda' [destaque meu], súdito o que obedece. O soberano tem direitos e o súdito, obrigações. O princípio da soberania popular é ateu e tirânico, porque onde há um súdito que não possui direitos e um soberano que não tem obrigações, há tirania. (Cortés, 1970:345)

Donoso aponta o Leviatã como a muralha contra a soberania popular. A soberania de direito divino conhecia limites,

mas a definida por Hobbes nega toda limitação para si mesma. Segundo ele, Deus não existe e o povo, desde o instante em que abre mão de seus direitos, faz-se escravo. Inflexivelmente lógico, Hobbes nega ao povo o direito de resistência à opressão, mesmo a mais delirante e absurda. (Cortés, 1970:345)

\section{As massas}

carecem de unidade, de previsão, de concerto, só a iminência do perigo pode obrigá-las a se reagrupar ao redor de uma bandeira. Quando passa o perigo, decai o entusiasmo, a unidade conjuntural formada pelo entusiasmo se atenua e se fraciona. (...) Quando se extingue o entusiasmo, o povo deixa de ser uma realidade para ser apenas um nome sonoro. $\mathrm{Na}$ sociedade, então, só existem interesses que se combatem, princípios que lutam entre si, ambições que se excluem e individualidades que se chocam. (Cortés, 1970:346)

O povo é fugaz e não garante a soberania. Sem esta última não existe poder, desaparecem os vínculos sociais. Para o pensamento conservador, a soberania popular é o perigo do liberalismo e das Luzes. "Em geral os povos recusam o poder que lhes é pedido e confirmam o poder que lhes é tomado. Todo poder ditatorial ou real que só busque apoio nas classes acomodadas é um poder perdido" (Cortés, 1970:346). Quem deseja pautar o poder por meio da Constituição é fraco. "O governo das classes vencidas é o constitucional, o das vencedoras foi, é, será perpetuamente a monarquia civil ou a ditadura mili- 
tar. Nunca os povos obedeceram gostosamente a alguém que não fosse um ditador ou rei absoluto.” (Cortés, 1970:347).

A soberania popular também é afastada por De Bonald: "O direito do povo a governar a si próprio é um desafio contra toda verdade. A verdade é que o povo tem o direito de ser governado" (apud Godechot, 1961:108). Edmund Burke enuncia o princípio de que o povo não é soberano porque o governo difere de um problema aritmético.

Foi dito que 24 milhões devem prevalecer sobre 200 mil. Verdade, se a Constituição de um reino fosse um problema aritmético. (...) A vontade de muitos, e seu interesse, devem diferir com freqüência, e uma grande vontade será a diferença quando eles, os muitos, fazem uma escolha ruim. (Burke, 1976:141)

Sendo o homem necessariamente associado e necessariamente governado, sua vontade 'não conta para nada no estabelecimento do governo' [destaque meu]; pois, uma vez que os povos não têm escolha e que a soberania não resulta diretamente da natureza humana, os soberanos não existem pela graça dos povos, a soberania não sendo a resultante de sua vontade, tanto quanto a própria sociedade. (Burke, 1976:141)

Não existe soberano sem povo, assevera De Maistre, nem povo sem soberano. Mas o povo tem dívidas para com o soberano, "deve-lhe a existência social e todos os bens que dela resultam. O príncipe só deve ao povo um brilho ilusório que nada possui em comum com a felicidade e que dela o exclui mesmo quase para sempre" (De Maistre, 1966:123). Inexiste soberania limitada, ou do povo. Existe soberania legítima ou não.

Dirão alguns: 'A soberania na Inglaterra é limitada.' Nada é mais falso. Apenas a realeza é limitada naquela ilha célebre. Ora, a realeza não é toda a soberania, pelo menos teoricamente. Quando os três poderes que, na Inglaterra, constituem a soberania, concordam, o que podem eles? É preciso responder, com Blackstone: TUDO. E o que se pode contra eles? NADA. (De Maistre, 1966:137, maiúsculas do próprio De Maistre).

Desde 1848 a doutrina do direito público tornou-se positiva, escondendo nesta palavra o seu embaraço: ela funda todo poder, mediante as mais diversas reconstruções, sobre o 'poder constituinte' do povo: isto é, no lugar da idéia monárquica de legitimidade entra a democrática. Neste 
ponto é incalculável na sua relevância o fato de que um dos maiores representantes do pensamento decisionista e filósofo do Estado católico, consciente de modo extremamente radical da essência metafísica de toda política, Donoso Cortés, diante da revolução de 1848, pudesse compreender que a época do realismo tivesse chegado ao fim. Não existe mais realismo, porque o rei não existe mais. Sequer existe uma legitimidade em sentido tradicional. Logo, só resta um resultado: a ditadura. É o mesmo resultado a que Hobbes chegou, procedendo na base da mesma conseqüência do pensamento decisionista, embora misturado com uma espécie de relativismo matemático. Auctoritas, non veritas facit legem. (Schmitt, 1972:73)

Carl Schmitt capta com lógica extrema a passagem da soberania no Estado, dos princípios teológicos com origem em Bracton ao seu esvaziamento nas doutrinas modernas e o contra-ataque do pensamento conservador.

Mas é preciso introduzir o Brasil nessa longa história. Importa sublinhar o estraçalhamento da soberania do povo e mesmo o regime da representação daquela soberania. Nos momentos de nossa Independência, as teses dominantes eram contrárias à soberania popular e, se esta não fosse apresentada pelos 'demagogos', a sua versão atenuada, a representativa. Surgimos no universo internacional como pais livres, batizados nas águas do conservadorismo contrarevolucionário. A historiografia nota que no Brasil surgiu uma invenção jurídica eficaz para afastar o perigo da soberania popular e mesmo da representação política. Na gênese do Estado brasileiro, imaginou-se resolver o conflito dos poderes. Ao mesmo tempo, tentou-se afastar as ameaças do povo que pretendeu substituir os príncipes. A instituição do poder moderador remediou todos esses males. Escutemos o conservador Guizot:

o mais simples bom senso reconhece que a soberania de direito, completa e permanente, não pode pertencer a ninguém; que toda atribuição de soberania de direito a uma força humana qualquer é radicalmente falsa e perigosa. Donde a necessidade da limitação de todos os poderes, quaisquer que sejam seus nomes e formas; daí a radical ilegitimidade de todo poder absoluto qualquer que seja a sua origem, conquista, herança ou eleição. Pode-se discutir os melhores meios de procurar o soberano de direito; eles variam segundo os tempos e os lugares; mas em nenhum lugar, em nenhum tempo, nenhum poder poderia ser o possuidor independente dessa soberania. Posto esse princípio, não é menos certo que a realeza, em todos os sistemas em que ela é considerada, apresenta-se como a personificação do soberano de direito. Escutai o sistema teocrático: ele vos dirá que os reis são a imagem de Deus na Terra, o que não 
quer dizer nada mais do que eles personificam a justiça soberana, verdade, bondade. Perguntai aos jurisconsultos: eles responderão que o rei é a lei viva; o que significa ainda que o rei personifica o direito soberano, a lei justa, que ele tem o direito de governar a sociedade. Interrogai a própria realeza no sistema de monarquia pura: ela dirá que personifica o Estado, o interesse geral. Em toda aliança ou situação considerada, ela sempre tem a pretensão de representar, reproduzir o direito soberano, o único capaz de governar a sociedade legitimamente. Nada nisso espanta. Quais são as marcas do soberano de direito, as marcas de sua natureza própria? Para começar, ele é único; porque só existe uma verdade, uma justiça, só existe um soberano de direito. Ele é o mais permanente, sempre o mesmo: a verdade não muda. Posto numa situação superior, estranha a todas as vicissitudes, a todas as possibilidades desse mundo; eles está no mundo, de certo modo, apenas como espectador e como juiz: este é o seu papel. Pois bem! Senhores, estas marcas racionais, naturais no soberano de direito, Guizot as realiza e as reproduz exteriormente na forma mais sensível, que dela parecem a mais fiel imagem. Abri o livro em que o Sr. Benjamin Constant tão engenhosamente representou a realeza como um poder neutro, um poder moderador, elevado acima dos acidentes, das lutas sociais, e que só intervém nas grandes crises. Esta não seria, por assim dizer, a atitude do soberano de direito no governo das coisas humanas? É preciso que haja nesta idéia algo muito próprio a mover os espíritos, pois ela passou com uma rapidez singular dos livros para os fatos. Um soberano dela fez, na Constituição do Brasil, a base de seu trono; a realeza é representada como poder moderador 'elevado acima dos poderes ativos', com espectador e juiz. ${ }^{8}$

A formulação liberal do próprio Benjamin Constant procurava impor limites à soberania popular, mas trazia também a preocupação de estabelecer os limites dos poderes e garantir a sua harmoniosa relação. Neutro, o poder moderador seria o apanágio da realeza, ${ }^{9}$ os ministros seriam responsáveis pelo governo e os legisladores não seriam pagos. $O$ julgamento pelo júri seria a norma e haveria liberdade de imprensa. Qual a base para a recusa da soberania popular? Ela é encontrada em Constant no texto sobre a diferença da liberdade entre os povos antigos e modernos. A primeira encontra-se na democracia direta assumida em Atenas, cujos males eram a guerra perene e a escravidão como seu resultado. Nada que já não estivesse em Tucídides. A segunda encontra-se no comércio, "que inspira nos homens o amor pela independência individual: atende às suas necessidades, satisfaz os seus desejos, sem intervenção da autoridade". Assim, o Estado deve ser contido em limites quando se trata da 
vida econômica, pois "sempre que o governo tomar conta dos nossos negócios, o fazem de modo pior e de maneira mais cara". Não devemos nos colocar nos assuntos de Estado, enquanto este último não deve se intrometer em nossos assuntos particulares. A liberdade moderna reside "no gozo tranqüilo da independência individual” (Guizot, 1828).

Erra todo aquele que desconhece limites para o exercício de qualquer poder.

Quando se estabelece que a soberania popular é ilimitada, cria-se e se deixa ao acaso na sociedade um grau de poder muito amplo e que se torna um mal, não importa em quais mãos esteja. Entregue-o a um, vários, todos, e o mal será o mesmo. (...) a soberania só existe num modo limitado. Onde começa a independência e a existência individual começa, termina a jurisdição da soberania. (Guizot, 1828)

O mercado liberta, e a vida privada deve ser o refúgio do indivíduo. Pela via oposta, encontra-se em Constant o elogio hobbesiano do indivíduo limitado ao particular, sem exteriorizações de suas certezas no plano público. A soberania popular entra no erro democrático: "A sociedade não pode exceder a sua competência sem tornar-se usurpadora, a maioria não pode fazer o mesmo sem tornar-se facciosa." O Contrato Social representa "o mais terrível instrumento auxiliar de todo tipo de despotismo" (Constant, 1872:7). Crime é crime, pouco importa a fonte de poder alegada por quem o comete: indivíduo, partido, nação. ${ }^{10}$

Toda a crítica de Constant a Hobbes, no tocante à soberania, vem do termo 'absoluto':

vê-se claramente que o caráter absoluto dado por Hobbes à soberania do povo é a base de todo o seu sistema. (...) a palavra 'absoluto' desnatura toda a questão e nos arrasta para uma nova série de conseqüências; é o ponto onde o escritor deixa o caminho da verdade para seguir rumo ao sofisma ao fim que ele havia proposto a si mesmo. (...) Com a palavra 'absoluto', nem a liberdade (...) nem o repouso nem a felicidade são possíveis em nenhuma instituição. O governo popular é apenas uma tirania convulsiva, o governo monárquico apenas um despotismo concentrado. (Constant, 1872)

Em face da tese da soberania absoluta, pensa Constant, Rousseau foi tomado de terror diante daquele 
poder monstruoso, e não encontrou preservativo contra o perigo inseparável de uma semelhante soberania, a não ser um expediente que tornava impossível o seu exercício. Ele declarou que a soberania não pode ser alienada, delegada, representada. Era declarar em outros termos que ela não pode ser exercida; era anular de fato o princípio proclamado. (Constant, 1872)

E criticando a idéia de 'absoluto' na soberania, mesmo popular, diz Constant: "O povo, segundo Rousseau, é soberano num aspecto, súdito noutro. Mas na prática os dois aspectos se confundem. É fácil para a autoridade oprimir o povo como súdito, para 'forçá-lo a manifestar como soberano a vontade que ela lhe prescreve"” (Constant, 1872).

Encontra-se nesse exato ponto a justificativa do Poder Moderador no pensamento de Benjamin Constant. Trata-se de idear os limites dos três poderes, impedindo a hipertrofia de um deles, como ocorreu na ditadura napoleônica, em nome do Executivo, e da ditadura jacobina, em nome do Legislativo. Ambos seguiram a tendência ao absolutismo, o que, segundo Constant, é idêntico a despotismo sem barreiras. Voltemos ao momento anterior ao de Constant, a gênese da Revolução Francesa. Ela derrubou um sistema de privilégios na condução do Estado, sistema que abarcava do rei a noblesse de robe. Destruir todo esse edifício e substituí-lo por um poder público distinto da situação social foi tarefa gigantesca. Pergunta: qual a natureza do regime novo? No antigo, a administração dependia do rei. Só com o tempo, mesmo curto, a legitimidade dos poderes passou do rei aos representantes eleitos.

A burocracia do antigo regime, produzida em séculos de controle do Estado pelo rei e por seus funcionários, perdeu a hegemonia estratégica em função do Legislativo eleito e, antes da República, do Conselho Real. De fato, ocorria uma forte tensão entre as duas fontes de legitimidade estatal. A monarquia não pode mais definir-se como o depósito da soberania estatal, combinando o Legislativo, o Executivo, o Judiciário. A nação, pelo Legislativo, faria as leis, a serem executadas pelo governo. Logo foi preciso estabelecer a separação dos poderes, na Constituição. A Assembléia Nacional desejou manter a monarquia, mas sem as prerrogativas antigas e sem que o clero e a nobreza mantivessem os velhos privilégios (venalidade dos cargos, privilégios dos nobres, justiça arbitrária, administração idem). Todos esses pontos são sintetizados na separação dos poderes. Na verdade, a Assembléia Nacional atenuou ao máximo os poderes que lhe faziam sombra, na guerra, nas finanças, na 
justiça etc. Os meios para esse controle dependiam da correta intelecção dos papéis e cargos. O de rei, pelo menos até a proclamação da República, era claro. $\mathrm{O}$ de ministro, nem tanto. Daí a restrição dos seus poderes e a instauração da responsabilidade perante o Legislativo. Eles poderiam ser impedidos por iniciativa da Assembléia e processados na Alta Corte especial. A mediação dessa corte atrapalhou bastante o controle dos ministros pelos deputados. A separação de poderes assim feita deixou os ministros sem legitimidade, porque eles não respondiam perante a Assembléia. Como não podiam controlar com eficácia os ministros, os deputados passaram a desconfiar de todo o ministério, produzindo um vazio na administração. Surge uma burocracia nova, distinta da que operava no Executivo e dependente do Legislativo. Com a ditadura, essas falhas pioraram e o Estado não conseguiu manter o ritmo das mudanças na ordem política de legitimação. $\mathrm{O}$ golpe de Estado que produziu a ditadura comissária não resolveu a luta entre os poderes, com resultados desastrosos. ${ }^{11}$

Nunca deveis esquecer, em toda posição que vos coloquem minha política e o interesse de meu império, que vossos primeiros deveres são para comigo, os segundos para com a França; todos os outros deveres, mesmo para com os povos que poderei vos confiar, vêm depois (Napoleão, Journal Moniteur, jul.1810, apud Madame de Staël (1983:420).

Ao dirigir-se desse modo ao sobrinho, filho de seu irmão Louis Bonaparte, destinado a ser o grão-duque de Berg, o imperador retomou a tradição absolutista cujo símbolo maior na França foi Luís XIV, com o dito L'État c'est moi. Vimos a relevância do pensamento absolutista para a questão da soberania e para a aplicação e leitura das leis. Sabemos que, após Napoleão, surgiram egocratas no Estado, especialmente no século XX, com o culto da personalidade nos regimes nazista, stalinista, fascista. ${ }^{12}$ Uma testemunha arguta do período napoleônico e do governo imperial é Madame de Staël, pessoa próxima ao Antigo Regime, por seu pai, e ao liberalismo de Benjamin Constant. No capítulo sobre as leis e a administração napoleônicas, ela pergunta:

É possível falar de legislação num país onde a vontade de um só homem decidia tudo; onde este homem, rápido e agitado com as ondas do mar durante a tempestade, não podia sequer suportar a barreira de sua própria vontade, se the opusessem a de ontem, quando ele desejava mudar o amanhã ?

O arbítrio do 'grande homem' definia o plano político, econômico, jurídico e bélico da França. Uma anedota contada pela autora é interessante. Um 
conselheiro disse a Napoleão que não autorizaria determinado ato, que beneficiava o ditador. "Ora bem!", responde o corso. "O Código Napoleão foi feito para a salvação do povo, e se tal salvação exige outras medidas, é preciso tomá-las."

Dois instrumentos jurídicos foram usados pelo poder imperial: leis e decretos. Leis eram emanadas de um simulacro de Legislativo, mas eram os decretos ditados pelo governante, discutidos no seu Conselho, a ação efetiva da autoridade. Quanto aos tribunais, o Código manteve o júri, definido pela Assembléia Constituinte. Porém os avanços nos procedimentos eram compensados, em favor do regime, por cortes especiais, comissões militares que julgavam delitos políticos, que resultavam em execuções sumárias. E aqueles tribunais condenavam pessoas por acusações anônimas, não raro sem relação direta com assuntos políticos. "Bonaparte não permitiu uma só vez que um acusado recorresse de condenação por delito político à decisão do júri." Os poderes eram unidos, sob o comando do imperador: "Era difícil distinguir a legislação da administração (...) pois ambas dependiam da autoridade suprema" (Stäel, 1983:413). O centralismo garantiu o mando despótico: "Todas as autoridades locais, nas províncias, foram gradativamente suprimidas ou anuladas." O trabalho da polícia, com delações e torturas, produziu um monstro que, finalmente, voltou-se contra os partidários do imperador destronado. A ideologia do imperador, em relação aos cidadãos particulares, era clara e distinta: eles deveriam, como exige Hobbes, ficar no plano privado; e "adquiram sempre mais dinheiro". Enquanto isso, os que mandam no Estado devem adquirir "sempre mais poder". A ditadura militar e burocrática imposta pela 'alma do mundo' ${ }^{13}$ resume-se no dito do próprio imperador: 'Les Français sont des machines nerveuses’. Máquinas: servem como instrumentos ou partes de instrumentos para ampliar o poder do Estado e de seus mestres. Nervosas: vivas como as forças naturais, numa simbiose sempre desejada pelos que desconhecem limites entre técnica e natureza. Napoleão toma como positivo o que, logo após, no romantismo, é indicado como um pesadelo terrível, a partir de Mary Shelley e o Frankenstein.

Após essa passagem pelo poder napoleônico, fica bem clara a intenção de Benjamin Constant ao sugerir o Poder Moderador como preventivo de tiranias. De um lado, ele limitaria as formas soberanas ligadas ao povo, sobretudo o despotismo do Legislativo. De outro, limitaria as pretensões do Executivo, garantindo o Judiciário. ${ }^{14}$ Evidentemente, as críticas aos abusos de poder descem nas noites dos tempos. No período absolutista, as denúncias contra tais abusos surgiram entre os puritanos e seus herdeiros, na América ou na França. 
No caso de Benjamin Constant, no entanto, existem antecedentes no instante em que a Revolução Francesa e a ditadura do Legislativo chegam à sua crise de morte. Como é o caso de Sieyès, para quem "os poderes ilimitados são um monstro em política. (...) a soberania do povo não é ilimitada." 15 O termidoriano Boissy d'Anglas retoma a norma hobbesiana, levando o cidadão particular ao plano estritamente produtivo, econômico, dele afastando as tarefas de governo. Assim, não se pode arrancar da atividade econômica "homens que melhor serviriam seu país pela atividade assídua em vez de vãs declamações e debates superficiais" (Rolland, 2003:195). D'Anglas, na verdade, com o Termidor, seleciona "os melhores" para dirigir o Estado, os que "possuindo uma propriedade são apegados ao país que a contém, às leis que a protegem, à tranqüilidade que a conserva" (apud Badiou, 1995:56).

Benjamin não foi termidoriano nem aceitaria as teses enunciadas por Boissy d'Anglas. Mas soube notar os excessos de poder de um setor do Estado e procurou definir o controle dos três poderes por intermédio do Poder Moderador, indicado como tarefa do rei. "Para que não se abuse do poder, é preciso que pela disposição das coisas o poder detenha o poder" (Constant, 1872). O sistema das balanças, no seu pensamento, opera na estrutura do Estado. O Legislativo seria bicameral, incluindo uma Casa dos Pares. Posteriormente ele divide o poder entre Legislativo e Judiciário, composto de juízes inamovíveis de ofício. Ideou, para corrigir a concentração do poder, o sistema de poderes e direitos departamentais e dos municípios. O rei como 'poder neutro' segue nessa orientação geral.

No Brasil, a concepção de Constant seguiu rumo inesperado. Vimos o elogio do uso da idéia de Poder Moderador em nosso país por Guizot. Há um evidente desvio do conceito na pena de Guizot no que é relativo ao conceito. Constant define aquele poder como neutro, o que significa que ele serve para coordenar os três poderes, sem neles interferir 'do alto'. A mesma operação de 'hierarquizar' os quatro poderes foi seguida no Brasil com a Constituição de 1824. A tendência centralizadora do poder real já fora iniciada em Portugal no século XVIII, com as reformas pombalinas. "As concepções de poder político, sociedade e Estado são assim formuladas em torno da noção de império civil, com fins de legitimar a monarquia portuguesa e consubstanciar projetos de atuação política" (Oliveira, 2004). ${ }^{16}$

Com as invasões napoleônicas de 1808 e a vinda da Casa Real para o Brasil, compõe-se uma corte no Rio onde se integram a nobreza, burocratas de 
alto escalão, serviçais e negociantes. No projeto idealizado, continua a noção de império português, com sede no Brasil. A cidadania foi entendida nos parâmetros da antiga metrópole: o 'povo' era a aristocracia, os 'homens bons' (ricos proprietários) sem sangue judeu. A representação 'popular' faz-se por petições, dando-se o direito de voto sem que os cidadãos tivessem presença ativa na esfera pública. Outro projeto é mais radical, pois admite a presença cidadã na vida pública, define autonomia para o Brasil. Nos dois projetos, cidadão é título que não cabe aos escravos, evidentemente, nem aos homens livres e pobres ("gente ordinária de veste").

O debate sobre a cidadania surge em 1821 na Assembléia do Rio de Janeiro, na eleição de representantes provinciais para a Assembléia de Lisboa, para redigir a Constituição portuguesa. O debate conduziu ao inesperado questionamento da autoridade de João VI. Foi proposto um projeto de governo representativo, visto pelos governantes como ligado "à força incontrolável da multidão", sobretudo num reino onde a enorme quantidade de escravos era perene ameaça (a revolta do Haiti em 1810 era um presságio).

A imensa dimensão do território brasileiro, as revoltas que se esboçavam, o exemplo dos países vizinhos que se tornaram repúblicas de tamanho inferior ao do Brasil, a memória da Revolução Francesa, as doutrinas de Benjamin Constant, todo esse amálgama de idéias, medos, repressão, definiu o momento inaugural do Estado independente que assumiu a forma de Império. Os que desejam um poder representativo e constitucional conseguem em 1822 a convocação da Assembléia. Mas no país surgem dois projetos não sintonizados e conflitantes: o da monarquia soberana (de São Paulo, sob liderança de José Bonifácio) e o de um governo constitucional (do Rio de Janeiro, liderado por José Clemente da Cunha). Quando Pedro I é aclamado, José Clemente afirma o princípio da soberania popular, enquanto Bonifácio enfatiza a supremacia do imperador.

Vence provisoriamente o primeiro projeto, sendo o império civil instituído por direito divino. Os defensores do segundo plano são perseguidos mas não deixam de conseguir a consideração, nos trabalhos da Constituinte, de suas idéias. Desse modo, o novo governo admitiria a liberdade política, mas sob a égide do poder supremo, definido pela pessoa do imperador. Em 1823, José J. Carneiro de Campos, ao discutir a sanção do soberano, apresenta a idéia do Poder Moderador. Exclusivo, aquele poder permite ao imperador controlar os demais poderes. A Constituição de 1824 incorpora o quarto poder e o amplia, 
pois ele pode dissolver a Câmara de Deputados, afastar juízes suspeitos etc. Tal poder foi alegado sempre que se tratava, no parecer dos governantes, da salvação do Estado. No mesmo plano, é restrita a autonomia do judiciário. Desse modo, o Poder Moderador torna-se supremo no Estado, acima dos três outros poderes.

A predominância do Poder Moderador sobre os demais manteve-se durante o império, incluindo o tempo de regência, quando o país passou por rebeliões sufocadas manu militari de norte a sul. Somadas as suspensões dos direitos e a permanente supremacia do imperador, tem-se como resultado uma difícil e quase improvável democratização do Estado. O permanente estado de rebelião e as necessidades do poder central definem o império como excessivamente preso ao modelo de concentração de poderes, o que molesta ainda em nossos dias o país, com o tipo de federação na qual os Estados têm realmente pouca autonomia, sobretudo em matéria fiscal. ${ }^{17}$ Com o fim do império, os positivistas tentaram acabar de vez com as forças liberais, com o conceito de ditadura, que acentua e mantém a preponderância do Executivo sobre o Legislativo, concentrando o poder diretor numa única pessoa. Falar em Legislativo, nessa doutrina, é impreciso e mesmo errôneo, visto que a Assembléia teria função fiscal: aprovar o orçamento do Estado. ${ }^{18}$ Em toda a república, as prerrogativas do Poder Moderador foram incorporadas, silenciosamente, à presidência do país - e com elas, a permanente pretensão dos ocupantes daquele cargo a assumir, como imperadores temporários, a preeminência e a intervenção nos demais poderes. Esse ponto permite indicar que o Estado é regido por força de pressupostos autoritários que, inclusive, produziram em plano mundial algumas lições de moderno despotismo.

Não por acaso Carl Schmitt (1969) refere-se ao Poder Moderador brasileiro em O Protetor da Constituição. Ali, o jurista defende, como em outros trabalhos, que apenas o Reichspräsident pode defender a Constituição em tempo de crise. O tema gira ao redor do artigo 48 da Constituição de Weimar. ${ }^{19}$ Ao fazer seu apelo aos poderes do Protetor da Constituição, Schmitt nega que o Judiciário possa exercer aquele papel, porque Judiciário é idêntico a normas e age post factum, sempre atrasado na correção dos desvios e fraturas institucionais. Para remediar aquelas situações, apenas o Reichspräsident poderia ser movido, legal e constitucionalmente. Como é habitual, Schmitt afasta o Judiciário e, ao mesmo tempo, o próprio Legislativo naqueles transes. Como diz Hans Kelsen, Schmitt reduz toda a Constituição de Weimar ao artigo 48 (H. Kelsen, Wer soll 
der Hüter der Verfassung sein?. Die Justiz 6, 1930-1931, apud McCormick, 1997:144.). Se, como diz Schmitt (1969:120), “a independência é a necessidade primeira para um protetor da Constituição”, e se os juízes ou deputados não podem cumprir aquele mister, segue-se que eles não são independentes, ou independentes o bastante para garantir o Estado. Desse modo, ele retira dos demais poderes a possibilidade de controlar e limitar o Protetor em seu poder excepcional. $\mathrm{O}$ estudo desse caso, importante na história dos poderes soberanos e da conexão teórica entre o que se passou na Alemanha e no Estado brasileiro, pode resultar em esclarecimentos sobre o nosso centralismo excessivo, a nossa quase inexistente federação, os excessivos poderes da presidência do Brasil. ${ }^{20}$ As ditaduras de Vargas e dos militares acentuaram tal centralismo. Para deixar isso bem claro, analiso rapidamente a essência do golpe de Estado de 1964, que tornou quase definitiva entre nós a suposta superioridade do Executivo federal sobre os demais poderes e sobre a sociedade civil.

Para fugir da sombra negra que segue todo golpe, o de 1964 foi apresentado como 'revolução' que impediria a tomada do poder pelos 'subversivos' (socialistas, comunistas, sindicalistas) e garantiria o verdadeiro regime democrático. Esse é o sentido do Ato Institucional 1, atribuído na sua maior parte a Francisco Campos. Diz o início daquele texto: “O que houve e continuará a haver neste momento, não só no espírito e no comportamento das classes armadas, como na opinião pública nacional, é uma autêntica revolução.” Assim, caem por terra as noções de legitimidade e de soberania vigente. Arremata o texto que assegurou longos anos à ditadura militar:

A revolução vitoriosa se investe no exercício do Poder Constitucional. Este se manifesta pela eleição popular ou pela revolução. Esta é a forma mais expressiva e radical do Poder Constituinte. Assim, a revolução vitoriosa, como o Poder Constituinte, se legitima por si mesma. (...) Ela edita normas jurídicas, sem que nisto esteja limitada pela normatividade anterior à sua vitória. (...) Fica, assim, bem claro que a revolução não procura legitimar-se através do Congresso. Este é que recebe deste Ato Institucional, resultante do exercício do Poder Constituinte, inerente a todas as revoluções, a sua legitimação. ${ }^{21}$

Francisco Campos, redator da Polaca - Constituição autoritária de 10/ 11/1937 - conhecia os enunciados de Schmitt, autor do importante livro $A$ Ditadura: das origens da idéia moderna de soberania à luta de classes proletárias, no qual descreve a lógica dos golpes de Estado e as normas impostas pelos que sobem 
ao poder daquele modo. ${ }^{22}$ É dele também a fórmula do golpe de Estado: "Soberano é quem decide sobre o estado de exceção". ${ }^{23}$ Crítico da soberania exercida pelos parlamentos, na encruzilhada sem esperanças do sistema representativo, ${ }^{24}$ acentua o poder do Chefe do Estado, o protetor da Constituição que exerce a soberania acima dos entraves da legalidade e das regras. O dirigente opera segundo a lógica da excepcionalidade. Vimos que em O Protetor da Constituiçãa ${ }^{25}$ encontra-se a referência ao Poder Moderador, tal como definido no Império brasileiro, como um dique contra a soberania popular e contra o que dela sobrou após as revoluções Francesa e Americana. A importância do Poder Moderador situa-se, justamente, no controle da soberania popular ou das pretensões parlamentares.

O importante, nos textos de Schmitt que se refletem na justificativa 'jurídica' do golpe em 1964, sobretudo a partir do Ato Institucional 1, encontra-se na defesa da exceção como elemento mais relevante do que a regra (defendida pelos liberais). A exceção, ao mesmo tempo que nega a soberania popular ao modo jacobino, permite a Schmitt o retorno a Thomas Hobbes. Schmitt (e seus partidários brasileiros) encontram em Hobbes o estratagema ditatorial, disponível para ser usado pelos que negam a forma democrática. Em Hobbes, julga Schmitt (se ele tem razão ou está desprovido de fundamentos, apenas os especialistas em Hobbes podem dizer), existiria a tese de um

governo que pode reclamar da necessidade concreta, do estado das coisas, da força da situação, para outras justificações não determinadas pelas normas, mas pelas situações (...). Isso encontra o seu princípio existencial na adequação ao fim, na utilidade (...), na conformidade imediatamente concreta das suas medidas. (Carl Schmitt, Legalität und Legitimität, 1932; cito com base na tradução italiana: Schmitt, 1972:217.)

A ditadura, resposta adequada para um estado de exceção, não precisa da legitimidade ao modo antigo e prescinde da legalidade positiva, ao modo de Kelsen e dos liberais. Sua força reside no fato de que ela emerge na crise, quando as formas jurídicas não garantem o povo e o Estado. Essa doutrina encontra-se na essência da idéia de 'revolução' que justificou o golpe em 1964. Além de lhe ser atribuída o mister de contragolpe preventivo, com o fim do governo legítimo, nele proclamava-se uma nova soberania, não mais advinda do povo, não mais adstrita ao Parlamento, não mais sujeita à legalidade, mas cuja fonte era o próprio soberano que, pelo golpe, apodera-se do Estado. Daí que o Parlamento e toda outra ordem jurídico-política receberiam sua existência e razão de 
ser do novo soberano. Os resistentes deveriam ser banidos da vida pública nacional. Essa é a lógica da 'depuração' do Parlamento, com as cassações de parlamentares, catedráticos etc. e de todos os atos seguintes do poder militar.

No entanto, o desejo da nova ordem, não submetida aos pressupostos da antiga, elevou-se no tempo longo, no Brasil, desde os anos do integralismo e da ditadura varguista. Não é possível esquecer que uma revista como $A$ Ordem, importante veículo das idéias católicas e conservadoras, pregava o fim do liberalismo político e jurídico. Mas a busca da ordem também teve outros motivos que, embora tão relevantes quanto os de cunho ideológico, exerceram um papel real no golpe e nos seus dias posteriores. $\mathrm{Na}$ imensa tragédia vivida pelo Brasil naqueles tempos, dois personagens foram estratégicos. Refiro-me aos militares e aos eclesiásticos.

Falemos dos segundos, para depois passar aos soldados. Após o Concílio Vaticano II, a Igreja Católica começava a enfrentar movimentos de base de leigos e sacerdotes que representavam obstáculos à hierarquia. As secularizações aceleradas dos padres, o seu empenho em lutas civis prenunciavam a quebra de algo sagrado no ordenamento católico, a dignidade eminente do bispo, submetido apenas à Sé romana. $\mathrm{O}$ peso da autoridade na instituição católica, sobretudo antes do Vaticano II, é tremendo. Isso faz com que as massas religiosas se mostrem publicamente sob a direção da hierarquia.

Desde longa data, clérigos e intelectuais previdentes, como Thales de Azevedo e o padre Júlio Maria, anunciavam o colapso institucional da Igreja no Brasil. O Vaticano II, provocando um aggiornamento do clero e dos leigos, ajudou as massas do catolicismo, em parte, a entrarem nos movimentos pelas mudanças sociais, sobretudo no campo explosivo da reforma agrária. A deserção dos fiéis iniciava o processo que hoje atinge formas numerosas e esvazia os templos em proveito dos auditórios laicos ou pentecostais, nos estádios e na televisão. Desafiada em sua idéia de ordem natural da sociedade, tolhida a disciplina hierárquica com freqüência inquietante, e vendo as massas dirigirem-se para setores secularizados, com o perigo socialista, ou mesmo - lembremos que estamos em plena colheita da Guerra Fria - comunista, surgem na Igreja os padres e os monges designados por Elias Canetti. A 'Cruzada do Rosário', do padre Peyton, as múltiplas marchas da 'Família, com Deus, pela Liberdade', os movimentos católicos conservadores que passam a disputar espaço com a Ação Católica especializada, em especial a juventude estudantil e universitária, que rumavam para opções políticas e até mesmo ideológicas opostas às da hierar- 
quia (é o caso da Ação Popular, a AP, liderada por Betinho, cujo teórico foi o jesuíta Padre Vaz), todos esses movimentos responderam às ameaças, reais ou supostas, à Igreja.

Milhões de fiéis foram conduzidos às ruas sob o báculo dos hierarcas fortemente ajudados pelos golpistas e pela imprensa, para mostrar - mais uma vez na história republicana, depois das demonstrações de força que marcaram os congressos eucarísticos - que a Igreja deveria ser levada em conta no futuro e no presente institucional brasileiro. Convergiu a Igreja, na sua face hegemônica, para os setores privilegiados e particulares que tramavam contra o governo.

Segundo Alberto Antoniazzi, o golpe de 1964

leva a uma 'reunião extraordinária dos Metropolitas' em 27-29 de maio, da qual sai uma declaração que aceita a intenção da Revolução de livrar o País do comunismo e agradece aos militares, mas faz ressalvas e o voto de que a reconstrução do País siga a Doutrina Social da Igreja. ${ }^{26}$

A Igreja acolheu com excelente ânimo o pior golpe dentro do golpe, o Ato Institucional número 5. No comunicado de 19 de fevereiro de 1969, os bispos, reunidos na CNBB, propõem ao governo tirânico uma "leal colaboração" para melhor cumprir "as reformas de base", sepultadas com o governo Goulart. Naquele texto, ainda, eles reconhecem a legitimidade do novo regime "institucionalizado em dezembro último" e chegam a considerar que os poderes de exceção permitiriam "realizar rapidamente as reformas de base". Para mostrar que a proposta de "leal colaboração" era dirigida a um poder inimigo de todas as reformas de base, basta referir os dados sobre a dívida externa do Brasil.

No momento do golpe de Estado em 1964, a dívida externa tinha subido para 2,5 bilhões de dólares; e quando o último general deixou a Presidência, em 1985, a dívida estava em mais de US\$ 100 bilhões. Assim, se multiplicou por quarenta em pouco mais de vinte anos de ditadura. Essa ditadura foi beneficiada pelo apoio indefectível do governo dos Estados Unidos e do Banco Mundial, que viram nela um aliado estratégico no continente sul-americano em um contexto de expansão da revolução cubana e das grandes lutas anticapitalistas e antiimperialistas. É importante notarmos que, antes do golpe de Estado de 1964, o Banco Mundial tinha se recusado a emprestar dinheiro para o Brasil, sob o comando do progressista presidente João Goulart (...), que tinha feito a reforma agrária. ${ }^{27}$

Enquanto os bispos oferecem "leal colaboração" ao governo militar reforçado pelo AI-5, reconhecem que, em face da repressão conduzida pelos 
militares, as elites católicas sofriam ameaças, o que as conduzia a se afastar da Igreja, penetrando numa "perigosa clandestinidade". ${ }^{28}$

Mas a linha oficial da Igreja foi mais do que ambígua: ela apoiou o regime, dando-lhe bênçãos. O episódio brasileiro teve antecedentes na história mundial, como a Concordata de Império entre a Igreja e o nascente (e legal) governo de Adolf Hitler. No artigo 1 do tratado, pode-se ler: "O Reich alemão garante a liberdade da profissão e o exercício público da religião católica”. No artigo 32, se enuncia: "Em razão das atuais circunstâncias particulares da Alemanha e em consideração das garantias criadas pelas disposições da presente Concordata, de uma legislação que salvaguarda os direitos e as liberdades da Igreja Católica no Reich (...), a Santa Sé editará disposições excluindo para os eclesiásticos e religiosos o ingresso nos partidos políticos e sua atividade a este respeito". E no artigo 5: "No exercício de sua atividade sacerdotal, os eclesiásticos gozam da proteção do Estado do mesmo modo que os funcionários do Estado". ${ }^{29}$ Como os bispos que apoiaram o golpe em 1964, a Santa Sé acreditou que a ditadura poderia ser aceita sem que os próprios fiéis fossem obrigados à "perigosa clandestinidade". Felizmente, para a restauração da plena democracia, muitos religiosos não aceitaram as ordens das autoridades religiosas.

Discutamos a outra instituição que, desde a Colônia, assegurou o território nacional e o Estado: as Forças Armadas. Para elas, como para a Igreja, a ordem hierárquica é essencial. Após a ditadura getulista, quando houve certa unidade de comando e obediência nas casernas, os soldados se preocuparam com a pequena democratização do governo Dutra, as crises do governo democrático de Vargas, as sucessivas formas de golpes e contragolpes de setores parlamentares que buscavam apoio nos quartéis (as famosas 'vivandeiras') antes do governo Juscelino. Após todos esses eventos, quando foram duramente questionadas a unidade de comando e a hierarquia, ocorreu a renúncia de Jânio Quadros, acuado por um parlamento hostil, sem maioria sólida possível. $\mathrm{Na}$ ocasião, com o veto do Alto Comando à posse de Goulart e com o parlamentarismo instalado pelo Congresso, ocorreu uma fratura perigosa aos olhos dos militares. Essa fenda ameaçaria a federação, de um lado, e a unidade das Forças Armadas. Refiro-me ao apoio do III Exército e dos demais setores leais ao vice-presidente da República, sob a liderança de Leonel Brizola.

Dada a cura provisória da crise institucional e federativa, com o parlamentarismo, os militares aparentemente aceitaram o status quo obtido pelos que dirigiam o Congresso. Mas a fratura ocorrida no interior dos quartéis, de modo 
público e notório, permaneceu na consciência militar à espera do que poderia ocorrer. As sucessivas manifestações de insubordinação dos soldados e patentes menores evidenciaram um processo geral de perda da autoridade do Executivo. As manobras políticas a diminuíram ainda mais. Seria preciso dar um basta aos que assim quebravam a hierarquia. A Igreja colocou massas nas ruas. As Forças Armadas prepararam a tomada das mesmas ruas pelos canhões. Quando as duas maiores forças de imposição do mando, uma espiritual e outra física, sentem que estão à beira da ruptura interna, e se quebra a linha de comando, elas reagem para sobreviver e tentam cortar a fonte de seus males, pelo menos a mais aparente. Se o governo não conseguia impor sua autoridade, mas até incentivava gestos de rebelião, era urgente substituir o governo, com a conivência do Congresso, manifestada sempre que golpes civis ou militares anteriores foram perpetrados.

A disciplina define o Exército. Trata-se de uma dupla disciplina. A declarada é a ordem, tal como descrita há pouco. A outra é a promoção. Esta última corresponde à capacidade de um militar para ser aguilhoado internamente pela ordem. Para cada ordem atualizada, fica um espinho dentro dele. Se é soldado raso, ele não pode desfazer-se desses espinhos, aninhados em seu corpo e alma. Ele obedece e se torna cada vez mais rígido em sua obediência maquinal. Para sair desse estado, só com a promoção. Quando promovido, ele se desfaz - nos outros - dos seus aguilhões/ordens. A disciplina secreta consiste no uso dos aguilhões/ordens armazenados.

Essa disciplina responde pelo fato de os exércitos mais poderosos do mundo terem seguido ordens de partidos totalitários, pelo menos até que vislumbrassem a derrota, sem pestanejar. "Estou cumprindo ordens". Sem tal frase, inexistiriam o fascismo, o nazismo, o stalinismo. O Alto Comando é o que menos ordens recebe, mas mesmo assim ele as recebe de quem possui autoridade para tal. Essa cadeia verticalizada de obediência, no caso dos soldados rasos, só explode nas situações de guerra em que o inimigo é disseminado, como nas guerras de guerrilha. Nessas horas, a solidariedade horizontal conta mais do que as ordens vindas de cima. Na vida comum, quando não há guerrilha do suposto inimigo externo ou interno, o Exército segue a disciplina e a ordem das promoções. Para que ambas existam, é preciso que a hierarquia e o próprio instituto militar sobrevivam. É absurdo para um soldado que cumpriu ordens a vida toda e subiu até o posto de coronel ou general-de-brigada imaginar que suas próprias ordens não serão obedecidas. Nesse caso, mesmo que o 
Alto Comando permita a 'insubordinação' e mesmo que o comandante supremo - o chefe de Estado - assuma uma suposta abertura democrática em face do Exército, quebrando a ordem rígida e a disciplina, eles serão desobedecidos, numa suprema tentativa de restaurar a ordem comum, com o golpe de Estado.

No Brasil em 1964, unidos à inquietude das altas hierarquias religiosas e à insubordinação ao governo civil e às angústias diante das movimentações de massas na sociedade e nos quartéis, os militares seguiram quem lhes prometia restaurar a ordem e manter a carreira, a promoção. Quando a sociedade no seu todo - por suas lideranças - não se sente ameaçada, o ato dos militares não encontra terreno fértil, mesmo dentro do Exército. Um golpe militar ocorre quando, às tensões externas, somam-se a angústia e as incertezas internas de manter toda uma existência baseada na disciplina, na hierarquia das ordens, na carreira e na promoção.

Tivemos pelo menos três elementos no golpe de 1964: em primeiro lugar, a pregação jurídica contrária ao liberalismo de autores como Francisco Campos e outros. Em segundo, a Igreja Católica, com a hierarquia. Em terceiro, as Forças Armadas, com a disciplina. Desses três elementos, somados aos demais, surgiu a justificativa do golpe de Estado. Durante todo o regime dos militares, o verdadeiro soberano, o Exército que ocupou o Executivo federal e todas as instâncias estratégicas de poder, acentou ainda mais fortemente o poder da presidência da República contra o Parlamento e o Judiciário.

Quando deixaram o controle direto da República, os militares legaram aos civis o centralismo que atenua ao máximo a federação e a autonomia dos poderes. Se os mesmos militares salvaram as aparências e os ritos do poder, trocando os presidentes em tempos certos, eles por sua vez instalaram nos órgãos públicos garantias de centralização que permanecem até hoje. Agora vamos ao mais grave. O presidente da República continua o prático do império, sendo a chefia do Estado um poder posto acima dos demais poderes. Ora, o Poder Moderador antes da República era vitalício e hereditário. Uma presidência imperial limitada por quatro anos sofre necessariamente a tentação de pressionar o Legislativo para que este último faça ou aprove leis favoráveis ao programa e às pretensões presidenciais. De modo idêntico, há pressões sobre o Judiciário para que reconheça a legitimidade das mesmas leis.

Dificilmente o nosso Estado e a sociedade entrariam na qualificação de formas democráticas. É preciso apurar, hoje, as noções de democracia, federalismo, sociedade civil etc. se quisermos pensar o mundo brasileiro. Tomemos a 
afirmação de que nosso modo de unir os Estados tem pouco de 'federalismo' e muito de Império. A jurista Anna Gamper pode nos ajudar a compreender a situação de nosso país, quando analisa as formas federativas e aponta as fraturas no projeto de União Européia:

Por unanimidade, as definições de federalismo reconhecem o fundamento da palavra latina foedus, que significa 'pacto'. Todas as teorias concordam que federalismo é um princípio que se aplica ao sistema que consiste em pelo menos duas partes constituintes, não totalmente independentes, que, juntas, formam o sistema como um todo. $\mathrm{O}$ federalismo, pois, combina o princípio da unidade e da diversidade (concordantia discors). As partes constituintes devem ter poderes próprios e devem ser admitidas a participar do nível federal. (Gamper, 2005)

Da definição escolhida pela autora, tomemos a parte em que ela afirma a exigência sine qua non que declara o seguinte: "as unidades constituintes devem ter poderes próprios”. Desde a Independência, o Poder Central brasileiro monopoliza todas as prerrogativas do Estado e não as partilha com os demais entes, supostamente unidos hoje por laços de federação. Se, em nosso caso, foedus significasse 'pacto', teríamos graus crescentes de autonomia, 'dos municípios ao Poder Central'.

Como o Império herdou as terras coloniais portuguesas, para ele o mais urgente era garantir as fronteiras do enorme país e impedir a secessão das províncias. Nesse fito, a repressão militar foi a tônica, o que se tornou dramático durante a Regência, quando várias unidades levantaram-se em busca não de autonomia, mas de plena soberania. A história do Brasil, desde aquela época até 1932 (Revolução Constitucionalista de São Paulo), tem sido a crônica de um controle férreo das províncias, depois estados, pelo Poder Central. É como se cada estado, sobretudo os que se levantaram em armas (Rio Grande do Sul, Pernambuco, Pará, Bahia, São Paulo, para recordar apenas alguns deles), fosse submetido à invasão permanente dos que dirigem o todo nacional. Resulta que a nossa 'federação' concede pouquíssima autonomia aos estados e municípios, em todos os planos da vida política, econômica etc.

A partir de Brasília, regras uniformes determinam até os detalhes da ordem nacional, desconhecem deliberadamente as diferenças regionais, culturais, geográficas etc. Do Oiapoque ao Chuí, há uma uniformização gigantesca que obriga cada uma das regiões a se pautar pelo tempo longo da enorme burocracia federal, perdendo tempo precioso para o experimento e as modifi- 
cações das políticas públicas em plano particularizado. Enquanto em outras federações, como a norte-americana (e apesar do grande centralismo daquele país), vigoram leis diversas em termos penais, educacionais, tecnológicos etc., no Brasil a mão de ferro do Estado central controla, dirige, pune e premia os estados, segundo sustentem os interesses dos ocupantes temporários da Presidência. Nesse controle, as oligarquias regionais surgem como operadores de face dupla: servem para trazer os planos do Poder Central aos estados e para levar ao mesmo poder as aspirações de estados e municípios. O lugar onde as negociações entre os dois níveis (central e estadual) ocorrem, normalmente, é o Congresso. Ali, presidência e ministérios buscam apoio para os seus planos, inclusive, e sobretudo, de leis. É impossível conseguir recursos orçamentários, por exemplo, sem as 'negociações', e nelas o modus operandi identifica-se ao conhecido 'é dando que se recebe'. Assim, os planos federais de inclusão social e democratização societária patinam na enorme generalidade do 'grande Brasil', enquanto as unidades aguardam as 'providências' de uma burocracia pesada, incapaz de entender os vários ritmos e formas de vida e pensamento regionais.

Nos impostos, a concentração irracional de poderes deixa estados e municípios sempre à míngua de recursos. Verbas provenientes de impostos ou a eles ligadas, como no caso das exportações, não são repassadas às unidades ou não são repassadas em tempo certo, permanecendo nas mãos dos ministérios econômicos. Governadores e prefeitos são reduzidos à quase mendicância junto ao Poder Central. Não ignoro as dificuldades gigantescas, se quisermos modificar essa forma de relacionamento federativo em nosso país. Valho-me novamente da jurista Anna Gamper (2005):

A economia política do federalismo e o federalismo fiscal tornaram-se um dos mais extensos e difíceis campos interdisciplinares da pesquisa sobre o federalismo, onde os conceitos de assimetria, competição e co-operação desempenham papel importante. Também é o campo em que os níveis inferiores que não participam do sistema, como os municípios, são admitidos excepcionalmente a entrar na arena como 'partes terceiras'. As relações financeiras entre a unidade central e as partes mais baixas e as terceiras partes são de suma importância para o sistema como um todo. A estabilidade financeira e a igualização, bem como a cooperação entre as partes da base, são obrigatórias para um efetivo sistema federal.

A distribuição das competências não é completa se não existem regras que dividem os poderes financeiros entre o poder central e as unidades constituintes. Se as partes constituintes que precisam de recursos para 
financiar suas responsabilidades as recebem sobretudo de subsídios que são a elas alocados pela unidade central (e devem ser acompanhados por certas condições que restringem seu poder de gasto), o arranjo fiscal parecerá um sistema de Estado não federal e não tanto um Estado federal que pressupõe teoricamente graus de autonomia financeira das partes constituintes, isto é, o poder de arrecadar taxas e gastar orçamentos próprios.

É praticamente impossível chegar à democratização da sociedade sem federalizar o Brasil. Um dia antes da escolha de Aldo Rebelo para a presidência da Câmara dos Deputados, assistimos à enésima caminhada de prefeitos do país inteiro rumo ao Congresso para reclamar recursos, autonomia, modificações em leis eleitorais e de estruturas municipais. Naquela tarde, como em muitas outras ocasiões, os prefeitos foram tratados como estranhos no parlamento federal, o que gerou um conflito só resolvido com o emprego da força física pela segurança da Casa das Leis. Enquanto tal situação permanecer assim, a fábrica das manobras corruptas (nas duas pontas, nos municípios e na capital da República) estará em pleno funcionamento.

Termino citando o longo mas relevante texto de um jurista que muito se preocupa com a forma democrática e republicana do nosso país.

A Constituição dos Estados Unidos criou o regime presidencial; nós engendramos o presidencialismo, que é a sua perversão máxima. Lá, o equilíbrio dos Poderes republicanos funciona harmoniosamente, num engenhoso mecanismo de checks and balances que faz inveja aos mais competentes relojoeiros. Aqui, a hipertrofia dos poderes presidenciais gerou um monstro macrocefálico, cujos membros são todos absorvidos pela cabeça. Para sermos justos, porém, é preciso reconhecer que essa aberração institucional não surgiu com a república, pois ela já estava presente e atuante durante todo o período imperial. O que se fez tão-só, com a derrubada da monarquia, foi uma adaptação semântica: passamos do império autêntico ao presidencialismo imperial. Na obra clássica em que fez o panegírico do pai, Joaquim Nabuco apenas uma vez permitiu-se censurá-lo. Foi a propósito de uma Circular de 7 de fevereiro de 1856, pela qual o velho Senador, em sua qualidade de Ministro da Justiça, entendeu de ditar regras de julgamento aos magistrados. É o traço saliente do nosso sistema político, escreveu Joaquim Nabuco, essa onipotência do Executivo, de fato o Poder único do regime (...). Apesar de todo o antagonismo de muitas de suas idéias com esse sistema, principalmente em matéria de garantias individuais e apesar da guerra que moveu à invasão francesa do contencioso administrativo, [Nabuco pai] foi 
um dos fundadores da onipotência do governo, convertido em última instância dos poderes públicos.

A República acentuou a onipotência do Chefe do Poder Executivo, ao cobri-la com o manto da irresponsabilidade, que a Constituição de 1824 reservava ao Imperador. (...) Atualmente, o Presidente da República não se limita a exercer um poder absoluto no ramo executivo do Estado: ele é também legislador, e dos mais prolíficos. $\mathrm{O}$ volume de medidas provisórias editadas e reeditadas, a maior parte delas sem a menor relevância ou urgência, já ultrapassa largamente o número de leis votadas pelo Congresso Nacional, desde a promulgação da Constituição. Para a convalidação espúria desse abuso, concorreu decisivamente a mais alta Corte de Justiça do País. Neste período crespuscular do Estado de Direito, o Supremo Tribunal Federal, cuja função precípua é 'a guarda da Constituição' (art. 102), tem transigido com todos os desvios, relevado todas as arbitrariedades, admitido todas as prevaricações. A pá de cal na indispensável independência do Supremo Tribunal Federal para custodiar a inviolabilidade da Constituição foi lançada com a Emenda Constitucional no 3, de 1993, instituindo a 'ação declaratória de constitucionalidade' (art. 102 - I, a). O judicial control, sem sombra de dúvida a maior criação constitucional dos norte-americanos, surgiu como instrumento de defesa dos direitos individuais contra o mais nocivo dos abusos políticos, aquele que associa Legislativo e Executivo na comum infringência da Constituição. No sistema presidencial de governo, com efeito, a lei não é apenas o ato do Poder Legislativo: ela conta também, necessariamente, com a aprovação do Executivo, que tem o poder de vetá-la. Quando o Presidente da República sanciona uma lei inconstitucional, ele se acumplicia com o legislador na violação da Carta Magna. Ora, a ação declaratória de constitucionalidade veio subverter inteiramente os termos dessa equação política. Ela não é uma defesa da cidadania contra o abuso governamental, mas, bem ao contrário, uma proteção antecipada do Governo contra as demandas que os cidadãos possam ajuizar para defesa de seus direitos. É uma espécie de bill de indenidade que o Judiciário outorga aos demais Poderes, um nibil obstat legitimador da ação governamental, antes que os cidadãos tenham tempo de reclamar contra ela. Por isso mesmo, o processo dessa aberrante demanda é suigeneris: não há contraditório, porque não há lide. Em se tratando de argüição de inconstitucionalidade de lei ou ato normativo, o Procurador-Geral da República deve ser previamente ouvido, e o Advogado-Geral da União defende o ato ou o texto impugnado (art. 103, $\iint 1^{\circ}$ e $3^{\circ}$ ). Mas no processo da ação declaratória de constitucionalidade, os autores agem sem contraditório: o Governo tem as mãos livres para demandar, sem que ninguém defenda os interesses dos governados. Por força desse 
vicioso mecanismo, a nossa Corte Suprema deixa de ser um tribunal, para se tornar um órgão oficial de consulta. Troca a posição de guarda da Constituição pela de colaborador do Governo. ${ }^{30}$

No Brasil, com a tentativa de impedir aqui os 'excessos' do liberalismo e da soberania popular, foi produzido um Estado dirigido no cimo por um soberano que detinha o poder de intervir nos demais poderes, o que impedia a autonomia do Judiciário. Na República, o centralismo e o papel eminente do Chefe de Estado o conduzem a exercer poderes imperiais, o que atenua a autonomia dos demais poderes. Em um país onde o segredo passa, muito facilmente, pela espionagem dos cidadãos e das instituições e no qual as práticas do SNI ainda existem no cotidiano, como atingir a transparência democrática? Em interessante livro sobre Carl Schmitt, um autor recente pergunta, em capítulo estratégico para sua análise sobre o presidente do Reich: “Guardião ou usurpador da Constituição?” (MacCormick, 1997:141). Enquanto existirem no Executivo as pretensões de manter a Constituição sob sua tutela, não teremos Estado de direito garantido entre nós.

O Estado de direito é bem traduzido pela réplica célebre do moleiro de Potsdam (...). Es gibt noch Richter in Berlin. Nem Frederico II conseguiu se opor ao direito de propriedade do moleiro, mesmo que o seu moinho fosse barulhento e incomodasse o soberano no castelo de Sans Souci. Isto é o Estado de direito. E nada mais. (Mouzon, 2005)

O Estado de direito é mais amplo do que imagina a parlamentar belga, autora das considerações citadas.

O povo reúne indivíduos, movimentos e grupos. Para os conservadores, tal soma é perigosa. A massa popular, imaginam os que liquidaram a Revolução Francesa, é criança a ser protegida. O grito reacionário foi lançado contra a tese kantiana sobre a maioridade cidadã. A tese conservadora chegou ao Brasil nos lábios de um ditador: "O indivíduo só tem deveres e não direitos. Ele tem deveres para com a natureza humana, para com a sociedade e para com Deus. (...) o direito do povo a governar a si próprio é um desafio contra toda verdade. A verdade é que o povo tem o direito de ser governado" (Getúlio Vargas, discurso de $1^{\circ}$ de maio de 1938, citado por Luís Werneck Viana, 1976:213). Repete-se nos trópicos a lição de Novalis (apud Romano, 1997:85) sobre o "Grande Eu, que é um e todos ao mesmo tempo". O povo criança, no todo estatal, deve ser regido pelos 'superiores'. À massa popular é negada a sobera- 
nia. Sem direitos individuais, impera o arbítrio dos que dirigem os coletivos. É próprio de sociedades escravas desprezar os indivíduos, em especial os pobres, para dar crédito apenas aos governantes e aos seus prepostos, como a polícia e similares. Os que ostentam armas em nome do Estado julgam-se acima das leis e dos homens. Os 'cidadãos comuns', crianças desobedientes, só merecem castigo. E sofrem torturas. Conservadora é a sociedade em que ricos devoram a renda nacional e recebem louvores de governantes e das colunas sociais.

Encerro com a citação de uma sentença que honra a magistratura. $\mathrm{Na}$ cidade de Recife, um jovem, em companhia de outros, tenta pegar mangas em quintal alheio. $\mathrm{O}$ menino estava próximo a determinado prédio que serve para serviços de galvanização. A Polícia ouve o tiro da arma empunhada pelo 'segurança' que se apavora com um ruído qualquer. Não vendo o autor do disparo, os fardados prendem o jovem, o torturam e o obrigam a entrar em tanque cheio de hidróxido de sódio (soda cáustica), o que lhe provoca deformidade permanente, lesões, dores. A tortura inclui tapas e pontapés. Surgidas as evidências dos abusos, a criança foi conduzida aos médicos. E os 'agentes da ordem' dela exigem que afirme ter caído acidentalmente no tonel. Mais tarde, a defesa proclama que a palavra da vítima tem 'credibilidade zero' porque tratava-se de um 'adolescente e imaturo'. Não disse nem precisava: era pobre, pertencia ao povo criança. Um torturador, percebendo a qualidade do líquido no qual jogara a criança, constatou que ela tinha de fato adoecido. A pele do garoto, diz o policial, ficou enrugada "como se fosse papel amassado". ${ }^{31}$

O juiz (Nivaldo Mulatinho Filho, do Recife), independente e inimigo da fraude e da força bruta que vestem o manto do Estado, condenou quem merecia, fez cumprir a lei. Mas o Brasil ainda agora é condenado por tortura pela Comissão de Direitos Humanos da ONU. Aquele organismo se preocupa com "a disseminação do uso excessivo da força pelos oficiais da lei, o uso da tortura para obter confissões, a execução extrajudiciária de suspeitos” em nossa terra. Mas quem habita os palácios de governo não ouve, não sente, não degusta a tristeza que tomba com a lágrima dos brasileiros a quem se nega o direito, porque se recusa a soberania. Enquanto os governos imperiais não respeitarem os indivíduos e o povo, a Carta Magna, como a pele dos nossos cidadãos pobres, será apenas papel amassado. Os que deveriam declarar a lei e proteger os direitos tomam a letra pelo espírito e colaboram com a tirania absoluta. Eles possuem credibilidade zero. 


\section{NOTAS}

${ }^{1}$ Ainda em 1604, nos Discours Chrestiens de la Divinité, Creation, Redemption et Octaves du Sainct Sacrement, Charron afirma que o título de honra próximo à Divindade é o de rei. Ele distingue entre a 'adoração' alta, a que se volta em direção ao divino, e a baixa, dirigida ao rei. Cf. Borreli (1993:62, nota 74).

${ }^{2}$ Para este passo, é importante consultar o livro de Gierke (1974) sobre Althusius: Johannes Althusius und die Entwicklung der Naturrechtlichen Staatstheorien. Uso a tradução italiana: Giovanni Althusius e lo Sviluppo Storico delle Teorie Politiche Giusnaturalistiche: contributo alla storia della sistematica del diritto.

3“...if the King or Magistrate prov'd unfaithfull to his trust, the people would be disingag'd." Um governo (Milton cita Aristóteles) "unaccountable is the worst sort of Tyranny; and least of all to be endur'd by free born men" (Milton, 1974:249 e ss.).

${ }^{4}$ Cf. 'Observações sobre o projeto de Constituição' que lhe foi apresentado por Catarina II da Rússia. Lembrança trazida por Laurent Versini, na edição que dirigiu das Oeuvres de Diderot (Diderot, 1995:507, t.III).

${ }^{5}$ Cf. 'Observations sur l'instruction de l'impératrice de Russie aux députés pour la confection des lois', in Oeuvres de Diderot (Diderot, 1995:507, t.III).

${ }^{6}$ Robespierre, relatório de 25/12/1793 à Convenção, em nome do Comitê de Salvação Pública. Esta análise pode ser lida com maiores detalhes no meu livro O Caldeirão de Medéia (Romano, 2001).

${ }^{7} \mathrm{O}$ paradoxo exposto no 'Essai sur l'application de l'analyse à la probabilité des décisions rendues à la pluralité des voix' reapareceu na Europa e sobretudo nos EUA nos últimos tempos. Na Europa, após o trauma alemão que permitiu eleger um partido absolutamente contrário à democracia e ao Estado de direito, possibilitando uma das piores aventuras totalitárias, sempre em nome do povo; nos EUA, o paradoxo de Condorcet é discutido com paixão depois das últimas eleições presidenciais. Cf. Barry Nalebuff, 'The last May be first; in a three-way race, it's tough to figure out the will of the people', The Washington Post, 21/06/2002. Barry Nalebuff é professor na Yale's School of Organization and Management. $\mathrm{O}$ artigo encontra-se disponível em <http://mayet.som.yale.edu/coopetition/news/ WpostJun92perot(53).html>. O trabalho mais conciso e explicativo sobre esse problema foi escrito por Eric Maskin: 'Is majority rule the best election method?' Ali, o autor segue os passos de Condorcet e os aplica às eleições norte-americanas das quais saiu vencedor $\mathrm{G}$. W. Bush. Disponível em <http://216.239.37.104/search?q=cache:k8ETA7Cy4UJ :www.sss.ias.edu/papers/papereleven.pdf + Condorcet+paradox + bush\&hl=pt $>$.

${ }^{8}$ Cf. François-Pierre-Guillaume Guizot, 1828. Disponível em: < http://www.eliohs.unifi.it/ testi/800/guizot/guizot_lez9.htm>. 
9 “The liberal, like the doctrinaire, thesis, rejected the doctrine of popular sovereignty as held by Rousseau, on the ground that no individual or body of men could lay claim to sovereignty that had not been delegated. For Benjamin Constant supremacy lay in the 'volonté générale', which did not, however, imply power for the masses. It was equally dangerous to put sovereignty uncontrolled into the hands of many as into the hands of one, it must be limited by the division of power. Authority must not reside in one branch of government any more than in another, and royal power should be a 'pouvoir neutre' whose function it is to set in harmonious motion the machinery of the other powers. Faguet calls Constant 'egalitaire sans être démocrate'; his is one of the best definitions of the rôle of the constitutional king that has ever been made" (Hudson, 1936:26).

${ }^{10}$ Cf. Benjamin Constant (1872:7 e ss.). Atitude semelhante à de Constant foi assumida por Schelling, antigo entusiasta da Revolução Francesa convertido em conservador. Por exemplo: "Colocar-se interiormente acima do Estado, apenas assim cada um pode e deve manifestar sua independência que, bem compreendida, torna-se a independência de todo um povo e se torna mais poderosa contra a opressão do que o ídolo tão louvado de uma Constituição que, mesmo em seu país de origem, tornou-se, em mais de um aspecto, uma fable convenue (em francês no original). Não invejeis a Constituição inglesa, porque ela saiu não de um contrato, mas da repressão e da violência e, graças a tal origem, tem acréscimos de não-razão, ausência de razão (no sentido liberal da palavra) que lhe deu até hoje a sua duração e estabilidade. Também não invejeis as massas inglesas, numerosas e grosseiras...". A semelhante advertência, Schelling (1946:332-333) acrescenta: "Restai um povo apolítico, pois a maioria dentre vós aspira mais a ser governada do que a governar, por causa dos lazeres que disso retira os quais deixam a alma e o intelecto disponíveis para outras coisas, uma felicidade maior do que recomeçar todos os anos querelas políticas, discórdias que só resultam em permitir aos mais incapazes ganhar fama e adquirir importância”.

${ }^{11}$ Para toda essa discussão, cf. Brown (1995).

${ }^{12}$ Seja permitido que eu cite um comentário correto sobre o nosso tema e sobre Claude Lefort, que orientou há muitos anos o meu doutoramento na École des Hautes Études: "O que é totalitarismo senão, no final das análises de Claude Lefort, a vontade de conjurar a indeterminação democrática? Da democracia, o totalitarismo retém a soberania do Povo/ Uno, mas quer lhe dar figura: será o partido único; das divisões sociais ele pretende triunfar reconduzindo a sociedade ao poder único, fundindo um e outro, abolindo a divisão fundamental entre sociedade civil e Estado; a legitimidade, a certeza serão tomadas sem contestação possível na instância nova de saber supremo que se tornou o secretário-geral do partido único. O monarca absoluto do Antigo Regime afirmava: 'O Estado sou eu'; o secretário-geral, no regime totalitário, contenta-se ao proclamar: 'A sociedade sou eu'. O totalitarismo (...) é uma doença histórica das democracias quando estas, inquietas, fatigadas com a sua indeterminação fundadora, se deixam tentar pela vontade de ocupar o espaço vazio do poder, afirmar certezas sobre a legitimidade, dar corpo à unidade social. $\mathrm{O}$ totalitarismo fundamenta-se então na recusa do direito individual, na erradicação dos direitos 
humanos, acreditando assim fechar o círculo que viu surgir a invenção democrática". O livro de Lefort (1976) é Un Homme en Trop: réflexions sur l'archipel du Goulag. O texto aqui citado que o analisa, sem assinatura, está disponível no site ADPF-Publications, do Ministério das Relações Exteriores da França: <http://www.adpf.asso.fr/>.

${ }^{13} \mathrm{Em} 13$ de outubro de 1806, Napoleão entrou na cidade de Iena. "Vi, escreveu Hegel, o Imperador, esta alma do mundo. (...) É uma sensação maravilhosa, ver um tal homem que, concentrado num ponto, sobre seu cavalo, se estende sobre o mundo e o domina" (Rosenkranz, 1966:246).

${ }^{14} \mathrm{~A}$ teoria do poder moderador neutro tem sido estudada com bastante insistência nos últimos anos, na França e em outros países. Cf. Guedes (1999) e Jaume (2000).

${ }^{15}$ Seção do 3 Germinal, ano III, citado por Patrice Rolland (2003:183), professor da Universidade Paris XII.

${ }^{16}$ Esta última parte segue integralmente as indicações e análises desse texto.

${ }^{17}$ Em Homens Livres na Ordem Escravocrata, Maria Sylvia Carvalho Franco (1997) apresenta a gênese do Estado brasileiro e as suas conexões com a sociedade na qual imperam o favor e a violência face a face. A autora explora a passagem do público ao privado e a superconcentração dos impostos no poder central, o que leva municípios e estados à perene condição de inadimplentes em relação ao núcleo do poder federativo e aos contribuintes. Cf. especialmente os capítulos 'Patrimônio estatal e propriedade privada' e 'As peias do passado'. Analiso esses pontos no texto 'A democracia e a ética', in Romano (2001:363 e ss.).

${ }^{18}$ Cf. Lins (1964:330) e também Romano (1979).

${ }^{19}$ Recordemos o artigo: "Caso a segurança e a ordem públicas forem seriamente (Erbeblich) perturbadas ou feridas no Reich alemão, o presidente do Reich deve tomar as medidas necessárias para restabelecer a segurança e a ordem públicas, com ajuda se necessário das forças armadas. Para este fim, ele deve total ou parcialmente suspender os direitos fundamentais (Grundrechte) definidos nos artigos 114, 115, 117, 118, 123, 124 e 153." ("Der Reichspräsident kann, wenn im Deutschen Reiche die öffentliche Sicherheit und Ordnung erheblich gestört oder gefäbrdet wird, die zur Wiederherstellung der öffentlichen Sicherbeit und Ordnung nötigen Maßnahmen treffen, erforderlichenfalls mit Hilfe der bewaffneten Macht einschreiten. Zu diesem Zwecke darf er vorübergehend die in den Artikeln 114, 115, 117, 118, 123, 124 und 153 festgesetzten Grundrechte ganz oder zum Teil außer Kraft setzen." Cf. Weimarer Republik, Weimare Reichsverfassung. Disponível em: <http://www.documentarchiv.de/wr/wrv.html > . Não por acaso disse Carl Schmitt que "nenhuma Constituição sobre a terra legalizou com tamanha facilidade um golpe de Estado quanto a constituição de Weimar” (McCormick, 1997:180).

${ }^{20}$ Para os estudos sobre Carl Schmitt no Brasil, cf. Maliska (2001). Um livro importante que expõe o pensamento de Schmitt com rigor é Carl Schmitte a Fundamentação do Direito (Porto Macedo Jr., 2001). 
${ }^{21}$ Para uma análise jurídica percuciente desse ponto, cf. o seguinte texto de Carlos Fernando Mathias de Souza, da Universidade de Brasília: 'Evolução histórica do direito brasileiro (XXX): o século XX', disponível em <http://www.unb.br/fd/colunas_Prof/ carlos_mathias/anterior_28.htm>.

${ }^{22}$ Cf. Schmitt (1928). Como estigma contra os brasileiros, a terceira edição daquela obra foi editada na Alemanha exatamente em 1964.

23 "Souverän ist, wer über den Ausnabmezustand entscheidet." Esta é a primeira frase do escrito sobre a teologia política de Carl Schmitt (cf. Schmitt, 1934). O enunciado apresenta-se não apenas em autores da chamada 'direita' internacional, mas também em textos da 'esquerda', como os de Walter Benjamin. Tem toda a razão Jean Pierre Faye, lingüista e teórico do pensamento totalitário, quando se refere a uma 'ferradura' terminológica que reúne os vários matizes da paleta ideológica. Durante o nazismo, com a 'colaboração' entre URSS e Alemanha, chegou a ser cunhada a expressão 'nacional-bolchevismo’.

${ }^{24}$ Cf. Schmitt (1926). Existe uma edição brasileira do texto. Cf. Schmitt (1996).

${ }^{25}$ Cf. Carl Schmitt, Der Hüter der Verfassung, texto ideado em 1929, mas publicado mais tarde. Uso a edição de 1969.

${ }^{26}$ Cf. Alberto Antoniazzi, 'Leitura sociopastoral da Igreja no Brasil (1960-2000): a Igreja Católica e a atuação política'. Conjuntura Social e Documentação Eclesial, 641. Disponível em: <http://www.cnbb.org.br/estudos/encar641.html>.

${ }^{27}$ Cf. Eric Toussaint (presidente do Comitê pela Anulação da Dívida do Terceiro Mundo, autor de A Bolsa ou a Vida. São Paulo: Perseu Abramo, 2001): 'Acordo com o FMI, estágio atual da auditoria da dívida e as responsabilidades do Governo Lula'. Disponível em: <http://www.jubileubrasil.org.br/dividas/eric.htm>.

${ }^{28}$ Cf. Declaração dos membros da Comissão Central da CNBB. São Paulo, 18.fev.1969. Texto reproduzido integralmente em Igreja e Governo, Extra 3:32-33, ano I, fev.1977. Cf. também Romano (1979:182).

${ }^{29}$ Cf. o texto citado integralmente em Mathivon (1936). Cf. também Lewy (1964). As desculpas católicas pelo mau passo podem ser encontradas em Gillod (1956), na introdução.

${ }^{30}$ Fabio Konder Comparato, 'Réquiem para uma Constituição’. Disponível em: <http:// www.dhnet.org.br/direitos/militantes/comparato/comparato_requiem.html>.

${ }^{31}$ Cf. Revista da Emespe, jul./dez.2000. p.633 e ss. 


\section{REFERÊNCIAS BIBLIOGRÁFICAS}

ANTONIAZZI, A. Leitura sociopastoral da Igreja no Brasil (1960-2000): a Igreja Católica e a atuação política. Conjuntura Social e Documentação Eclesial, 641. Disponível em: <http://www.cnbb.org.br/estudos/encar641.html>.

BADIOU, A. Qu'est-ce qu'un thermidorien? In: KINTZLER, C. \& RIZK, Hadi (Eds.). La République et la Terreur. Paris: Kimé, 1995.

BORRELI, G. Ragion di Stato e Leviatano. Bologna: Il Mulino, 1993.

BOTERO, G. La Ragion di Stato. Roma: Donzelli, 1997.

BROWN, H. G. War, Revolution, and the Bureaucratic State: politics and army administration in France, 1791-1799. Oxford: Oxford University Press, 1995.

BURKE, E. Reflections on the Revolution in France. Middlesex: Penguin, 1976.

COMPARATO, F. K. Réquiem para uma Constituição. Disponível em: < http:// www.dhnet.org.br/direitos/militantes/comparato/comparato_requiem.html $>$.

CONSTANT, B. Principes de politique applicables à tous les gouvernements représentatifs et particulièrement à la constitution actuelle de la France. In: CONSTANT, Benjamin. Cours de Politique Constitutionelle ou Collection des Ouvrages Publiés sur le Gouvernement Représentatif. Paris: Guillaumin et Cie., 1872.

CORTÉS, D. Obras Completas. t. I. Madri: BAC, 1970.

CHRÉTIEN-GONI, J.-P. Institutio Arcanae. In: LAZZERI, C. \& REYNIÉ, D. Le Pouvoir de la Raison d'État. Paris: PUF, 1992.

DAGOGNET, F. Philosophie de l'Image. Paris: Vrin, 1984.

DECLARAÇÃO DOS MEMBROS DA COMISSÃO CENTRAL DA CNBB. São Paulo, 18 fev. 1969. Texto reproduzido integralmente em Igreja e Governo, Extra 3, ano I:32-33, fev. 1977.

DE MAISTRE, J. Du Pape. Genève: Droz, 1966.

DIDEROT, D. Oeuvres de Diderot. Ed. Laurent Versini. Paris: Robert Laffont, 1995.

EDWARDS, T. Grangraena. Terceira parte (1646). Edição fotostática publicada por The Rota Ed. e Universidade de Exeter, 1977.

FRANCO, M. S. C. Homens Livres na Ordem Escravocrata. 5.ed. São Paulo: Unesp, 1997.

GAMPER, A. A global theory of federalism: the nature and challenges of a federal state. German Law Journal, 10, $1^{\circ}$.out.2005. Disponível em: <http:// www.germanlawjournal.com/>.

GIERKE, O. Natural Law and the Theory of Society: 1500 to 1800. Boston: Beacon Press, 1960. 
GIERKE, O. Johannes Althusius und die Entwicklung der Naturrechtlichen Staatstheorien. Tradução italiana: Giovanni Althusius e lo Sviluppo Storico delle Teorie Politiche Giusnaturalistiche: contributo alla storia della sistematica del diritto. Torino: Einaudi, 1974.

GILLOD, M. Catholicisme Allemand. Paris: Cerf, 1956.

GODECHOT, J. La Contre-Revolution. Paris: PUF, 1961.

GUEDES, T. D. Le pouvoir neutre et le pouvoir modérateur dans la Constitution brésilienne de 1824. In: BENJAMIN CONSTANT EN L'AN 2000: NOUVEAUX REGARDS. Actes du Colloque des 7 et 8 mai 1999, organisé à l'occasion du vingtième anniversaire de l'Institut et de l'Association Benjamin Constant.

GUIZOT, F.-P.-G. Cours d'histoire moderne: histoire générale de la civilisation en Europe, depuis la chute de l'empire romain jusqu'à la révolution française, $9^{\mathrm{e}}$ Leçon - 13 juin 1828. Electronic Library of Historiography. Disponível em: < http:/ /www.eliohs.unifi.it/testi/800/guizot/guizot_lez9.htm>.

HILL, C. (Ed.). The Levellers and the English Revolution. Manchester: C. Nicholls \& Company, 1961.

HILL, C. Intellectual Origins of the English Revolution. Londres: Granada Publishing Ltd., 1965.

HUDSON, N. E. Ultra-Royalism and the French Restoration. Cambridge: The University Press, 1936.

JAUME, L. (Org.). Coppet, Creuset de l'Esprit Libéral. Paris: Economica et Presses Universitaires d'Aix-Marseille, 2000.

LA BOÉTIE, E. Une oeuvre inconnue de la Boétie: les mémoires sur l'Édit de janvier 1562. Ed. Paul Bonnefon. Revue d'Histoire Littéraire de la France. 24e année. Paris: Librairie Armand Colin, 1917.

LA BOÉTIE, E. Le Discours de la Servitude Volontaire. Paris: Payot, 1976.

LEFORT, C. Un Homme en Trop: réflexions sur l'archipel du Goulag. Paris: Seuil, 1976.

LEWY, G. Le concordat entre l'Allemagne et le Saint Siège. In: LEWY, G. L'Église Catholique et l'Allemagne Nazie. Paris: Stock, 1964.

LINS, I. História do Positivismo no Brasil. São Paulo: Cia. Editora Nacional, 1964.

LUTAUD, O. Des Révolutions d'Angleterre à la Révolution Française: le tyrannicide \& killing no murder (Cromwell, Athalie, Bonaparte). La Haye: Martinus Nijhoff, 1973.

LUTAUD, O. Les Deux Révolutions d'Angleterre: documents politiques, sociaux, religieux. Paris: Aubier, 1978.

MALISKA, M. A. Acerca da legitimidade do controle da constitucionalidade. Revista Crítica Jurídica, 18 mar. 2001, separata de artigo. 
MATHIVON, A. Catholicisme, National-Socialisme et Concordat du Reich. Paris: Librairie Génerale du Droit et Jurisprudence, 1936.

McCORMICK, J. P. Carl Schmitt's Critique of Liberalism: against politic as technology. Cambridge: Cambridge University Press, 1997.

MILTON, J. John Milton Selected Prose. Ed. C. A. Patrides. Harmondsworth: Penguin, 1974.

MONTESQUIEU. Esprit des Lois. Paris: Gallimard 1951. (Pléiade).

MOUZON, A.-S. Bulletin des Interpellations et des Questions Orales. Parlamento da Região de Bruxelas-Capital. Reunião de 28.abr.2005. Disponível em: <www.weblex.irisnet.be/data/arccc/biq/2001-02/00001/f/images.pdf>, supplemental result.

OLIVEIRA, E. R. de. A idéia de império e a fundação da monarquia constitucional no Brasil (Portugal-Brasil, 1772-1824). In: ANAIS DO XVII ENCONTRO REGIONAL DE HISTÓRIA. Anpuh/SP/Unicamp, 2004. CD-ROM.

PORTO MACEDO JR., R. Carl Schmitt e a Fundamentação do Direito. São Paulo: Max Limonad, 2001.

REVISTA DA EMESPE, jul./dez.2000.

ROLLAND, P. La garantie des droits. Droits Fondamentaux, 3, dez. 2003.

ROMANO, R. Brasil, Igreja contra Estado. São Paulo: Kayrós, 1979.

ROMANO, R. Conservadorismo Romântico: origem do totalitarismo. 2.ed. São Paulo: Unesp, 1997.

ROMANO, R. O Caldeirão de Medéia. São Paulo: Perspectiva, 2001.

ROSENKRANZ, K. Vita Di Hegel. Tradução italiana de Remo Bodei. Firenze: Mondadori, 1966.

ROUSSEAU, J.-J. Contrat social. Livro IV, capítulo IV. In: ROUSSEAU. Oeuvres Complètes. Paris: L'Intégrale, 1971.

SCHELLING, F. Introduction à la Philosophie de la Mythologie. $23^{\mathrm{e}}$ leçon. Paris: Aubier, 1946.

SCHMITT, C. Die geistesgeschichtliche Lage des heutigen Parlamentarismus. Munique: Duncker \& Humblot, 1926.

SCHMIT'T, C. Die Diktatur: Von den Anfängen des modernen Sowveränitätsgedankens bis zum proletarischen Klassenkampf. 2.ed. Munique, Leipzig: Duncker \& Humblot, 1928.

SCHMITT, C. Politische Theologie: Vier Kapitel zur Lehre von der Souveranität. Munique: Duncker \& Humblot, 1934.

SCHMITT, C. Der Hüter der Verfassung. Berlim: Duncker \& Humblot, 1969.

SCHMIT'T, C. Le Categorie del Politico'. Bologna: Il Mulino, 1972. 
SCHMIT'T, C. A Crise da Democracia Parlamentar. Trad. Inês Lohbauer. São Paulo: Scritta, 1996.

SOUZA, C. F. M. de. Evolução histórica do direito brasileiro (XXX): o século XX. Disponível em: <http://www.unb.br/fd/colunas_Prof/carlos_mathias/ anterior_28.htm>.

STAËL, Mme de. Considérations sur la Révolution Française. Ed. J. Godechot. Paris: Tallandier, 1983.

TOUSSAINT, E. Acordo com o FMI, estágio atual da auditoria da dívida e as responsabilidades do Governo Lula. Disponível em: <http:// www.jubileubrasil.org.br/dividas/eric.htm>.

VIANA, L. W. Liberalismo e Sindicato no Brasil. Rio de Janeiro: Paz e Terra, 1976. 


\section{O Estado Brasileiro: GÊnese, crise,} ALTERNATIVAS

Carlos Nelson Coutinho

\section{[ I ]}

Nos últimos anos, tornou-se lugar-comum a afirmação de que o Estado brasileiro está em crise. Esta não parece ser uma questão polêmica entre os vários analistas, estejam eles situados à esquerda ou à direita do espectro político-ideológico. Também não é um ponto polêmico definir qual Estado está em crise: independentemente do nome que lhe é dado - 'varguista', 'populista', 'intervencionista' -, o Estado em crise é aquele que se constituiu a partir da chamada Revolução de 1930.

Menos consensual é a constatação de que muitos dos traços dessa formação estatal brasileira ora em crise têm raízes já no início da nossa história. Isso significa que o Brasil se caracterizou até recentemente pela presença de um Estado extremamente forte, autoritário, em contraposição a uma sociedade civil débil, primitiva, amorfa. Valendo-se de categorias weberianas, Raymundo Faoro mostrou como esse autoritarismo tem sua origem na burocracia patrimonialista portuguesa, pela qual fomos colonizados, mas cujos traços mais característicos se mantiveram no Brasil independente (Faoro, 1976). Sem negar a importância da análise de Faoro, prefiro me valer de categorias de Antonio Gramsci: tomando como base a distinção entre Oriente e Ocidente por ele estabelecida, eu diria que o Brasil foi, pelo menos até os anos 1930, uma formação políticosocial de tipo 'oriental', na qual o Estado é tudo e a sociedade civil é primitiva e gelatinosa. (Lembremos que, para o pensador italiano, o Ocidente se caracteriza por uma 'relação equilibrada entre Estado e sociedade civil'.) ${ }^{1}$ 
Essa 'orientalidade' do Brasil, que fez com que o Estado brasileiro fosse erradamente visto por muitos como o demiurgo das relações sociais, pareceme causa e efeito de particulares processos de transformação social, que foram característicos de nossa história e que, sob formas transfiguradas, repetem-se de certo modo ainda hoje. Falando esquematicamente, podemos dizer que o Brasil experimentou sempre, quando teve de enfrentar tarefas de transformação social, processos de tipo eminentemente 'não clássico', ou seja, diversos daqueles por que passaram alguns países hoje desenvolvidos, que terminaram por gerar sociedades de tipo 'ocidental', liberal-democráticas.

Há três paradigmas que nos ajudam a pensar essa modalidade peculiar pela qual o Brasil transitou para a modernidade e enfrentou os grandes desafios históricos de sua evolução política, praticamente desde a Independência. O primeiro desses paradigmas é o conceito de 'via prussiana', elaborado por Lenin. ${ }^{2}$ Com ele, o revolucionário russo busca conceituar processos de modernização que ele chamou de 'não clássicos', ao comparar o caso da Prússia com os casos 'clássicos' dos Estados Unidos, da Inglaterra e da França. Partindo sobretudo do modo pelo qual o capitalismo resolveu (ou não resolveu) a questão agrária, Lenin chamou de 'via prussiana' um tipo de transição ao capitalismo que conserva elementos da velha ordem e, nessa medida, tem como pressuposto e como resultado um grande fortalecimento do poder do Estado.

Conceito análogo aparece em Gramsci, ou seja, o conceito de 'revolução passiva'. Tomando como base a análise do processo de unificação nacional italiano do século passado, conhecido como Risorgimento - mas generalizando o conceito também para outros eventos históricos, como, por exemplo, o fascismo -, o pensador italiano chama de 'revolução passiva' os processos de transformação em que ocorre uma conciliação entre as frações modernas e atrasadas das classes dominantes, com a explícita tentativa de excluir as camadas populares de uma participação mais ampla em tais processos. Gramsci diz que as revoluções passivas provocam mudanças na organização social, mas mudanças que também conservam elementos da velha ordem. Trata-se, essencialmente, de transformações - ou de revoluções, se quisermos - que se dão 'pelo alto'. Ao referir-se ao tipo de Estado que resulta de processos de revolução passiva, Gramsci fala em 'ditaduras sem hegemonia'.

Finalmente, há um conceito mais 'acadêmico', ou seja, com melhor trânsito na universidade, que também ajuda a pensar o caso brasileiro: o conceito de 'modernização conservadora', elaborado pelo sociólogo norte-americano Barrington 
Moore Jr. ${ }^{4}$ Ele distingue entre diferentes caminhos de trânsito para a modernidade, um que leva à criação de sociedades liberal-democráticas, outro que leva a formações de tipo autoritário e mesmo fascista. Embora não cite nem Lenin nem Gramsci, Moore Jr. distingue os dois caminhos valendo-se de determinações análogas àquelas apontadas pelos dois marxistas - ou seja, entre outras, a conservação de várias características da propriedade fundiária pré-capitalista e, conseqüentemente, do poder dos latifundiários, o que resulta do fato de que a 'moderna' burguesia industrial prefere conciliar com o atraso a aliar-se às classes populares.

\section{[2]}

É evidente que o caso brasileiro gera uma 'via brasileira', ou seja, tem suas próprias especificidades. Mas me parece que esses três paradigmas nos permitem captar algumas determinações decisivas da formação do Estado que se gestou em nosso país, sobretudo depois da Independência. Lembraria, para confirmar isso, eventos curiosos, como o fato de o primeiro imperador brasileiro ter sido filho do rei de Portugal; ele foi Pedro I no Brasil e Pedro IV, algum tempo depois, em Portugal. Isso revela quanto foi débil aquela ruptura, ou seja, a ruptura que nos trouxe de uma situação formalmente colonial para a condição de país independente. Além disso, junto com esse imperador, herdamos também a burocracia portuguesa, que aqui já estava e que foi reforçada com a vinda de D. João VI, em 1806. Portanto, se observarmos bem, veremos que o processo de independência não se constituiu absolutamente em uma revolução no sentido forte da palavra, isto é, não representou um rompimento com a ordem estatal e socioeconômica anterior, mas foi apenas, de certo modo, um rearranjo entre as diferentes frações das classes dominantes. Para dar um exemplo situado na outra ponta do nosso percurso histórico, recordo também que o primeiro presidente civil após o ciclo militar iniciado em 1964 foi o ex-presidente da Arena (Aliança Renovadora Nacional), isto é, do partido de sustentação da ditadura militar.

Essas tendências 'prussianas' ou 'passivas' foram causa e efeito de uma presença sempre muito forte do Estado na vida brasileira. Isso já se manifesta claramente, como vimos, no processo da Independência, no qual se revela um traço que teve importantes conseqüências: conhecemos um Estado unificado antes de sermos efetivamente uma nação. Isso suscita uma questão que aqui não cabe analisar em detalhe, mas apenas mencionar: se o Brasil tivesse conhecido 
um processo de independência diverso, gerado efetivamente de baixo para cima, ou seja, por meio da ação de movimentos republicanos e relativamente populares - como os que ocorreram, por exemplo, não só em várias regiões da América espanhola, mas também entre nós nas 'inconfidências' mineira e, sobretudo, baiana -, talvez não fôssemos hoje um único país, um país unificado. E essa eventual fragmentação não teria sido, necessariamente, um fato negativo, caso tais repúblicas tivessem sido construídas com participação popular, forjando assim estruturas mais democráticas ou, no mínimo, menos oligárquicas. $\mathrm{Na}$ verdade, creio que o chamado 'milagre' da unificação brasileira se deve essencialmente ao fato de que nossa Independência se deu 'pelo alto'. E isso criou este fato anômalo de que o Brasil foi um Estado antes de ser uma nação.

Decerto, com o passar do tempo, constituímos uma nação brasileira, ainda que - o que é positivo - com suas muitas especificidades regionais. Mas cabe insistir que a nação brasileira foi construída a partir do Estado e não a partir da ação das massas populares. Ora, isso provoca conseqüências extremamente perversas, como, por exemplo, o fato de que tivemos, desde o início de nossa formação histórica, uma classe dominante que nada tinha a ver com o povo, que não era expressão de movimentos populares, mas que foi imposta ao povo de cima para baixo ou mesmo de fora para dentro e, portanto, não possuía uma efetiva identificação com as questões populares, com as questões nacionais. Para usar a terminologia de Gramsci, isso impediu que nossas 'elites', além de dominantes, fossem também dirigentes. O Estado moderno brasileiro foi quase sempre uma 'ditadura sem hegemonia', ou, para usarmos a terminologia de Florestan Fernandes, uma “autocracia burguesa” (Fernandes, 1975:289 e ss.).

Creio que toda essa tradição, a de um Estado superposto à nação, reproduz-se na Revolução de 1930, a qual - e isso me parece hoje algo consensual entre os pesquisadores - certamente assinala, malgrado seus limites, um momento de importante descontinuidade com a velha ordem. Costuma-se dizer que foi a partir de 1930 que ingressamos na 'modernidade', mas me parece mais preciso dizer que o movimento liderado por Getúlio Vargas contribuiu para consolidar definitivamente a transição do Brasil para o capitalismo. Depois da Abolição e da Proclamação da República, o Brasil já era uma sociedade capitalista, com um Estado burguês, ${ }^{5}$ mas é depois de 1930 que se dá efetivamente a consolidação e a generalização das relações capitalistas em nosso país, inclusive com a expansão daquilo que Marx considerava o 'modo de produção especificamente capitalista', ou seja, a indústria. ${ }^{6}$ 
E 1930 é, seguramente, a forma mais emblemática de manifestação de via prussiana, de revolução passiva, de modernização conservadora em nossa história. ${ }^{7} \mathrm{Na}$ Revolução de 1930, setores das oligarquias agrárias, aqueles não ligados diretamente ao mercado externo, deslocam do papel de fração hegemônica no bloco no poder a oligarquia cafeeira, cooptam alguns segmentos da oposição da classe média (que se expressavam no movimento tenentista) e empreendem processos de transformação que irão se consolidar efetivamente a partir de 1937, com a implantação da ditadura do Estado Novo, quando se promove, sob a égide do Estado, um intenso e rápido processo de industrialização pelo alto. Sabemos muito bem que a industrialização brasileira, ou, pelo menos, a política de industrialização, não foi resultado consciente da ação do empresariado. A historiografia mais séria provou que o empresariado industrial paulista, vanguarda do empresariado nacional, não participou da Revolução de 1930; ao contrário, apoiou a candidatura oligárquica de Júlio Prestes, ainda que no programa da Aliança Liberal já estivesse explícita a idéia de que era necessário promover uma política de industrialização em nosso país. O principal protagonista de nossa industrialização foi, desse modo, o próprio Estado, não só por meio de políticas cambiais e de crédito que beneficiavam a indústria, mas também mediante a criação direta de empresas estatais, sobretudo nos setores energético e siderúrgico. ${ }^{8}$ Pode-se assim dizer que, a partir dos anos 1930 e pelo menos até a implantação do neoliberalismo nos anos 1990 (quando o capital financeiro assume a supremacia), a fração preponderante no bloco de poder que governou o Brasil foi o capital industrial.

Nesse período, alguns importantes teóricos da direita autoritária - como Oliveira Vianna, Azevedo Amaral e Francisco Campos - se manifestaram claramente a favor de uma 'via prussiana', ou seja, de uma ação transformadora pelo alto, como o caminho mais adequado para a nossa modernização. Cabe aqui uma distinção. Também na época, um pensador marxista como Caio Prado Júnior, em sua análise do Brasil, mostrou que essa forma de modernização conservadora era, entre nós, um fato histórico, mas indicou ao mesmo tempo os efeitos nefastos que isso trouxe para o presente brasileiro (déficit de cidadania, dependência externa, formas de coerção extra-econômica na relação entre capital e trabalho etc.). ${ }^{9}$ Ao contrário, os nacionalistas autoritários - que, de resto, eram ideólogos explícitos do Estado Novo implantado em 1937 - afirmavam que a transformação pelo alto, baseada no Estado, deveria ser o verdadeiro caminho de modernização a ser adotado pelo Brasil. Para eles, cabia ao Estado construir a nação brasileira. 
De certo modo, eles formulavam um diagnóstico do Brasil da época que tinha pontos em comum com aquele formulado pela esquerda, em particular por Caio Prado Jr.: para os defensores do autoritarismo, o Brasil teria uma sociedade fraca, anômica, fragmentada, na qual as classes sociais não se haviam ainda constituído plenamente. Mas, enquanto a esquerda apresenta como solução para esse problema o fortalecimento da sociedade civil, sua organização e dinamização, os defensores do 'Estado autoritário' pensavam que a solução consistiria precisamente em fazer do Estado o instrumento básico da construção da nacionalidade brasileira. ${ }^{10}$ Essa proposta estratégica 'prussiana' foi implementada pelo governo varguista, sobretudo após a implantação do Estado Novo. E, de certo modo, continuou a predominar ao longo do período 'populista', iniciado com o segundo governo Vargas (1950-1954).

\section{[3]}

Outro traço importante, também iniciado a partir de 1930 e que vai marcar decisivamente o Estado brasileiro posterior, é uma forte marca corporativista, que assumiu, inclusive, a forma do corporativismo de Estado, já utilizada pelo fascismo europeu. Na década de 1930, difundiu-se não só a constatação de que estávamos nos tornando uma sociedade moderna - na qual havia, portanto, a emergência explícita de interesses múltiplos e diversificados, freqüentemente conflitantes - mas também a consciência de que, de certo modo, seria necessário criar mecanismos de representação desses interesses. Afirmavase também, ao mesmo tempo, que a maneira correta de construir tal representação era no interior do próprio Estado, por meio de um sistema corporativo muito próximo daquele que estava sendo posto em prática pelo fascismo italiano. O pós-1930 introduziu assim uma novidade, já que 'a questão social' era vista na República Velha simplesmente como um 'caso de polícia'.

Essa orientação corporativa se expressa de modo claro na tentativa de incorporar ao aparelho de Estado o movimento sindical, que tivera uma autonomia bastante grande ao longo dos anos 1920, ou mesmo até o início dos anos 1930. ${ }^{11}$ Porém, a partir sobretudo de 1937, os sindicatos se tornam instituições ligadas diretamente ao Ministério do Trabalho, ou seja, ao Estado; e não se deve esquecer que essa subordinação corporativa dos sindicatos ao Estado prossegue, pelo menos legalmente, até a Constituição de 1988. Temos assim um Estado que impõe uma representação corporativa dos interesses da classe tra- 
balhadora, ou melhor, de segmentos da classe trabalhadora, já que - pelo menos até 1963 - não era contemplada a organização sindical dos trabalhadores rurais. Um modo de evitar a universalização da representação dos trabalhadores foi impedir, até o fim do ciclo militar, a formação de centrais sindicais.

Cabe lembrar que foi também de modo corporativo que se fizeram representar os interesses da própria burguesia brasileira: a partir de 1930, a representação burguesa é incorporada ao Estado não só por meio de sindicatos análogos aos da classe trabalhadora, mas sobretudo por meio das várias câmaras setoriais então criadas, como, por exemplo, o Instituto do Açúcar e do Álcool, do Café, do Cacau etc.; e esse tipo de representação, passando pelos chamados grupos executivos do governo Kubitschek, prossegue durante a ditadura militar, mediante o que Fernando Henrique Cardoso chamou de 'anéis burocráticos' ${ }^{12}$ Esses organismos estatais eram formados por membros das várias frações da burguesia e por funcionários do Estado. Portanto, também a representação dos interesses burgueses era feita de modo corporativo, no próprio interior do aparelho de Estado, e não por meio da sociedade civil. Por ter se limitado durante muito tempo a essa forma de representação 'econômicocorporativa', a burguesia brasileira renunciou a elaborar (na terminologia de Gramsci) uma consciência 'ético-política', com o que se tornou incapaz por muito tempo de formular um projeto nacional hegemônico.

Quando a sociedade civil começa a emergir no Brasil, ${ }^{13}$ o que tem lugar sobretudo a partir dos anos 1930, logo se manifesta a tendência do Estado a absorvê-la como um seu momento subordinado, o que se expressa precisamente no modo corporativo de representação dos interesses. Com isso, é favorecido o permanente fortalecimento do Estado e a não menos permanente tendência ao debilitamento da sociedade civil.

\section{[4]}

Esse modelo de Estado burguês - intervencionista e corporativista perdura, pelo menos, até o governo Geisel, ainda que conhecendo manifestações fenomênicas bastante variadas nos diferentes períodos históricos de sua evolução. Por exemplo: ao longo do chamado período populista, quando prossegue e se radicaliza a implementação da política econômica nacional-desenvolvimentista iniciada durante o primeiro governo Vargas, mantêm-se as características essenciais desse tipo de Estado. Perdura, em primeiro lugar, a noção de que a modernização, 
ou seja, o desenvolvimento econômico, tem no Estado um protagonista central. Em segundo lugar, conserva-se a idéia de que alguns interesses podem certamente se fazer representar, mas somente quando essa representação tem lugar no interior do próprio Estado. Como se sabe, durante todo o período populista, o sindicalismo continuou legalmente submetido à estrutura corporativista criada durante o Estado Novo.

$\mathrm{O}$ atrelamento ao Estado, mesmo quando este esteve provisoriamente em mãos de forças progressistas, tinha muitas implicações políticas no que se refere à autonomia do movimento dos trabalhadores. Muitas das greves gerais que eclodiram no período populista eram promovidas pelo próprio governo, tendo como base de apoio os trabalhadores das empresas estatais. Foi o caso, por exemplo, da greve decretada quando João Goulart quis fazer de Brochado da Rocha, um ilustre desconhecido, seu primeiro-ministro, em 1962. Desse modo, o movimento sindical continuou a ter escassa autonomia, uma situação que só começa efetivamente a se alterar no final do período, quando se criam o Comando Geral dos Trabalhadores (CGT) e outros organismos horizontais, que estavam situados fora da legalidade, mas que eram aceitos e até estimulados pelo governo Jango.

Essa esquizofrenia entre o real e o legal era, aliás, uma característica dessa época de crise do pacto populista. Basta lembrar que tínhamos, por um lado, um Partido Comunista ilegal, mas não clandestino, que até se reunia com o presidente da República; e, por outro, que funcionava uma central sindical (o CGT) proibida explicitamente por lei, mas que também não era clandestina e que aparecia igualmente como importante interlocutora do governo.

Isso demonstra que os breves anos do governo Jango (mas também, ainda que em menor medida, o período governamental de Juscelino Kubitschek) constituem uma época na qual a sociedade civil tornou-se mais ativa e buscou se articular de modo autônomo, anunciando de certo modo os primeiros sintomas de crise daquele Estado centralizador e corporativista surgido na esteira da Revolução de 1930. Tal panorama levou ao que Octávio Ianni chamou de 'colapso do populismo', ou seja, ao fim de uma específica modalidade de articulação das forças sociais e políticas no interior desse tipo de Estado burguês (Ianni, 1968). Mas que tal Estado ainda não estivesse em crise terminal é o que foi comprovado pelo golpe de 1964: o regime que então se instalou destruiu o pacto populista, mas conservou - e até mesmo desenvolveu e reforçou - os traços mais perversos da nossa formação estatal anterior. Por isso, mais uma 
vez conhecemos uma 'revolução passiva', na qual as 'reformas de base' (agrária, bancária, universitária etc.), reivindicadas pelo movimento social golpeado em 1964, foram realizadas pelo alto, com um sentido nitidamente conservador.

Com efeito, o golpe não rompeu com o tipo de articulação corporativista e autoritária entre Estado e sociedade civil e não retirou o Estado de suas funções no terreno da regulação da economia. Toda a retórica da 'revolução' de 1964 se baseava na idéia de que era preciso estabelecer a 'verdade cambial', a 'verdade salarial' etc., ou seja, o pleno funcionamento do mercado, uma retórica muito parecida, aliás, com a dos neoliberais de hoje. Mas o que se viu, na prática, foi que o Estado ditatorial continuou a exercer uma decisiva influência na economia, até fortalecendo sua ação nesse terreno, por meio da manutenção, do desenvolvimento e da criação de numerosas empresas estatais de intervenção direta na economia. Além disso, continuou a ter em face da sociedade civil uma atitude que poderia ser assim resumida: quando não fosse possível assimilar corporativamente um organismo da sociedade civil, então este deveria ser reprimido. A política governamental, como era de se prever numa ditadura, não foi nunca a de respeitar a autonomia da representação dos interesses sociais.

É evidente que, ao longo de todo o período que vai dos anos 1930 até o governo Geisel, houve numerosas variações: embora a proposta de modernização que poderíamos chamar de 'nacional-desenvolvimentista' tivesse se conservado, ocorreram mudanças no modo de implementá-la. Uma delas, talvez a mais importante, foi o diferente modo pelo qual se tratou o capital estrangeiro. Num primeiro momento (aquele ligado ao nome e à herança de Vargas), a intervenção do Estado na economia visava favorecer sobretudo o capital nacional, garantindo as precondições para o seu desenvolvimento e, ao mesmo tempo, buscando controlar e até restringir o ingresso do capital estrangeiro. A partir do governo Juscelino - e, ainda mais acentuadamente, ao longo da ditadura militar -, essa restrição desapareceu, criando-se em conseqüência o famoso tripé em que o Estado funcionava como instrumento de acumulação a serviço tanto do capital nacional quanto - e sobretudo - do capital internacional. ${ }^{14}$

É importante observar que essa abertura ao capital estrangeiro não significa uma atitude contrária aos interesses do capital nacional. Na verdade, a burguesia brasileira rapidamente se deu conta de que tinha muito a lucrar com sua associação ao capital internacional, ainda que como sócia menor. ${ }^{15}$ Portanto, a idéia de que haveria no Brasil, como em outros países do Terceiro Mundo, uma 'burguesia nacional' enquanto fração de classe contrária ao imperialismo - uma 
idéia que teve papel destacado na estratégia política do Partido Comunista Brasileiro (PCB) entre 1954 e 1964, que se centrava na luta por um 'governo nacionalista e democrático' - revelou-se uma idéia sem correspondência na realidade: não havia nenhum segmento significativo da burguesia brasileira realmente interessado em impedir o ingresso do capital estrangeiro em nosso país. Assim, a virada 'entreguista' representada pelo governo Juscelino não pode ser considerada uma ruptura com o modelo 'nacional-desenvolvimentista' implementado a partir de 1930, mas, ao contrário, uma maior adequação sua aos efetivos interesses das classes dominantes brasileiras.

\section{[5]}

Um dos traços mais característicos desse modelo de Estado burguês que conhecemos ao longo de meio século é que ele - como, em geral, todos os Estados que resultam de revoluções passivas - era um Estado no qual a supremacia da classe no poder se dava por meio da dominação (ou da ditadura) e não da direção político-ideológica (ou da hegemonia). Recordo brevemente que, para Gramsci, hegemonia é um modo de obter o consenso ativo dos governados para uma proposta abrangente formulada pelos governantes. Ao contrário, o que caracteriza aquilo que Gramsci chamou de 'ditadura sem hegemonia' é o fato de que, nesse tipo de Estado, existe certamente uma classe dominante, que controla direta ou indiretamente o aparelho governamental, mas o projeto político dessa classe não tem o respaldo consensual do conjunto ou da maioria da sociedade. Nesse caso, lembra ainda Gramsci, pode-se falar de hegemonia de uma fração da classe dominante sobre as outras frações, mas não do conjunto dessa classe sobre o conjunto das classes subalternas. ${ }^{16}$ Portanto, os cinqüenta anos que vão de 1930 a 1980 conhecem um tipo de Estado burguês que se caracteriza, em sua maior parte, pela presença de uma dominação sem hegemonia. É este o caso, evidentemente, dos momentos de ditadura explícita, como os que vão de 1937 a 1945 e de 1964 a 1985, que cobrem cerca de trinta anos.

Decerto, uma importante variação ocorre durante os quase 15 anos do chamado período 'populista' (1951-1964). ${ }^{17}$ Sem que houvesse desaparecido o caráter autoritário e corporativista do Estado, tem lugar aqui o que eu chamaria de 'hegemonia seletiva'. É inegável que, em grande parte da época populista, a proposta nacional-desenvolvimentista - que era claramente uma 
proposta voltada para a expansão do capitalismo no Brasil e, portanto, uma proposta burguesa, que interessava sobretudo à fração industrial dessa classe - obteve o consenso de segmentos importantes das camadas populares, muito particularmente da classe operária urbana com carteira assinada. Mas é preciso insistir no caráter seletivo, isto é, limitado e excludente, dessa hegemonia. ${ }^{18}$ Ou seja: embora houvesse segmentos das classes subalternas dos quais se tentava obter e realmente se obtinha consenso, inclusive por meio de concessões (direitos trabalhistas, aumentos salariais etc.), tinha-se ao mesmo tempo a exclusão de outros setores importantes dessas classes, como é o caso dos trabalhadores rurais e dos urbanos autônomos, excluídos não só dos direitos sociais, mas também - graças à proibição do voto aos analfabetos - dos direitos políticos.

De qualquer modo, apesar desses limites, penso que durante o período populista a burguesia brasileira obteve um razoável grau de consenso e pôde assim dominar com relativa hegemonia, o que explica a permanência de instituições liberal-democráticas (ainda que combinadas com elementos de corporativismo e de indiscutível supremacia do Executivo sobre o Legislativo) ao longo do período. Mas tratou-se - e gostaria de insistir nisto - de uma hegemonia seletiva, limitada e, nesse sentido, precária e instável, como as muitas crises ocorridas no período permitem constatar.

\section{[6]}

O elemento conteudístico mais importante dessa forma política autoritária e centralizadora de Estado é que ele sempre esteve claramente a serviço de interesses privados. O fato de esse Estado ter sido muito forte e de ter aparentemente se superposto à ordem privada não anula, de modo algum, uma realidade fundamental: a de que toda essa força esteve sempre - em primeira ou em última instância, mais em primeira do que em última - a serviço de interesses estritamente privados.

A primeira manifestação desse 'privatismo' reside no fato de que esse Estado sempre apresentou (para usar o conceito de Weber) fortes características patrimonialistas, sendo tratado na prática, pelos seus ocupantes, como propriedade pessoal, o que levou aos muitos fenômenos de nepotismo, clientelismo, corrupção etc., que todos conhecemos e que prosseguem de certo modo até hoje. 
Mas essa privatização do público deve ser compreendida sobretudo com base na teoria econômica marxista, ou seja, no fato de que a intervenção do Estado na economia visou fundamentalmente à criação das condições mais favoráveis à expansão do capital privado. Ninguém deve supor que a Companhia Siderúrgica Nacional, para citarmos um caso emblemático, foi criada para dar lucros ao Estado, os quais pudessem ser utilizados, por exemplo, numa ampla política de redistribuição de renda. A CSN sempre esteve, e muito particularmente no período da ditadura, a serviço do aumento da taxa de lucro do capital privado, sobretudo internacional. Por que a CSN, em determinado momento, aproximou-se da falência? Simplesmente porque vendia aço a preço subsidiado para aumentar o lucro das montadoras transnacionais sediadas no Brasil.

Dei o exemplo da CSN, mas podemos comprovar esse 'subsidiamento' do capital privado pelo setor público em todos os campos da intervenção do Estado na economia. Wilson Suzigan, um economista do Instituto de Pesquisa Econômica Aplicada (Ipea), fez nos anos 1970 uma pesquisa que revelou o seguinte: enquanto a taxa média de lucro das empresas estatais era de cerca de $11 \%$, a taxa de lucro do setor privado, tanto internacional quanto nacional, situava-se em torno de 30\% (Suzigan, 1976, capítulo III). Claro que as empresas estatais precisam ter um mínimo de lucro, se é que querem acumular e reinvestir sem o auxílio do Tesouro (auxílio, aliás, de que elas muitas vezes se valeram, gerando inflação, ou seja, aumentando o lucro do setor privado às custas do bem-estar da população assalariada). Mas o objetivo último de tais empresas não é, de modo algum, gerar lucros para si próprias, ou mesmo para o Estado, e sim criar condições para que o capital privado possa existir e se expandir; tanto é assim que elas, via de regra, se estabelecem em setores que não interessam ao capital privado, pelo menos num primeiro momento, não só porque o investimento inicial nesses setores é muito alto, mas também porque a rotatividade do capital - ou seja, o tempo necessário para que o investimento dê lucro - é bastante longa. Portanto, não há interesse ou possibilidade de que o capital privado, pelo menos o nacional, invista nesses setores, que são, contudo, imprescindíveis para a existência de um capitalismo razoavelmente auto-sustentado. ${ }^{19}$

Assim, o Estado brasileiro foi sempre dominado por interesses privados. Decerto, isso caracteriza o Estado capitalista em geral, não sendo uma singularidade de nossa formação estatal; mas esse privatismo assumiu aqui traços bem mais acentuados do que em outros países capitalistas. Sempre que há 
uma dominação burguesa com hegemonia, o que ocorre nos regimes liberaldemocráticos, isso implica a necessidade de concessões da classe dominante às classes subalternas, dos governantes aos governados. Portanto, nesses casos, o Estado - ainda que, em última instância, defenda interesses privados - precisa ter também uma dimensão pública, já que é preciso satisfazer demandas das classes trabalhadoras para que possa haver o consenso necessário à sua legitimação. Não é outra a explicação, por exemplo, da existência do Welfare State nos países mais desenvolvidos; neste caso, graças às lutas das classes trabalhadoras, foi possível construir, a partir de políticas estatais, uma rede educacional e de seguridade social que tem um indiscutível interesse público.

No Brasil, o pouco que foi conquistado nesse sentido - e, também entre nós, arrancado pelas lutas das classes trabalhadoras - não infirma o fato de que a característica dominante do nosso Estado foi sempre ter sido submetido, no essencial, a interesses estritamente privados. Criamos juridicamente, por meio de um longo processo que se inicia nos anos 1930, um aparente Estado do bem-estar; mas foi com muita felicidade que Francisco de Oliveira o chamou ironicamente de 'Estado do mal-estar social'. E isso porque, na verdade, o pretenso Welfare brasileiro não funciona: embora juridicamente a Constituição consagre importantes direitos sociais, estes não são implementados na prática, não tanto porque o país seja pobre ou o Estado não disponha de recursos, como freqüentemente se alega, mas sobretudo porque não há vontade política de fazê-lo, ou seja, porque não há um verdadeiro interesse público embasando a ação de nossos governantes. Eles preferem pagar a dívida pública e assegurar o chamado equilíbrio fiscal (por meio de enormes superávits primários) do que atender às reais demandas da população brasileira.

\section{[7]}

Esse modelo de Estado - ou, mais precisamente, esse paradigma de organização das relações entre Estado e sociedade e da representação dos interesses - revelou estar em crise no período da transição da ditadura à democracia em nosso país. Assim, para entendermos melhor a crise desse Estado e as alternativas para sua transformação, devemos analisar os elementos dessa transição, ou seja, o 'de onde' e o 'para onde' se transitou.

$\mathrm{O}$ 'de onde', certamente, é a ditadura militar implantada no Brasil em 1964. Para tentar captar suas principais determinações, devemos, antes de mais 
nada, defini-la negativamente: se o termo 'fascismo' tem a pretensão de conceituar fatos reais e não apenas de servir como instrumento de denúncia, a ditadura militar brasileira não foi fascista. $\mathrm{O}$ fascismo se caracteriza por ser um regime reacionário, certamente ditatorial, mas que tem a especificidade de se apoiar numa base de massas organizada, cujo recrutamento se dá sobretudo entre as camadas médias, mas também entre setores populares, inclusive da classe operária. Essa característica já se manifesta no período de preparação da ascensão fascista ao poder: com efeito, o movimento fascista organiza desde o início aparelhos típicos de sociedade civil (partidos, sindicatos, associações etc.), combinando mecanismos legais e extralegais em sua luta pelo poder. Uma vez implantado como regime, o fascismo incorpora ao Estado os organismos de sociedade civil antes criados por ele, gerando assim uma forma política totalitária. ${ }^{20}$ Dessa forma, penso que o fascismo - tanto como movimento quanto como regime - tem lugar em países que Gramsci chamaria de 'ocidentais', ou seja, nos quais já existe uma sociedade civil forte e articulada, como era precisamente o caso da Itália e da Alemanha nas décadas de 1920 e 1930.

Numa formação social de tipo 'oriental' - ou, como no caso brasileiro e latino-americano em geral, de ‘ocidentalização' ainda não plenamente desenvolvida -, as classes dominantes não precisam recorrer a mecanismos próprios da sociedade civil quando querem frear a ascensão das classes subalternas por meio de uma ditadura, de uma dominação sem hegemonia. Nesse caso, ao contrário do fascismo 'clássico', verifica-se a tentativa de desativar e mesmo reprimir a sociedade civil. Isso faz com que esse tipo de regime seja, também aqui em contraste com o fascismo, fortemente desmobilizador; seu objetivo não é organizar massas, mas precisamente desorganizá-las. Se ditaduras desse tipo professam alguma ideologia, trata-se de uma ideologia da não-ideologia: o discurso dos militares brasileiros, por exemplo, codificado na famigerada 'doutrina de segurança nacional', era o de que a política deveria ser evitada porque, ao expressar e legitimar conflitos, ela dividiria a nação, divisão que prejudica a ordem e a segurança, apresentadas como condição imprescindível para o desenvolvimento. ${ }^{21}$

Isso não significa, porém, que a ditadura brasileira tenha tido êxito em seu esforço por eliminar a sociedade civil. Ao contrário, a sociedade civil cresceu enormemente ao longo do período ditatorial. ${ }^{22} \mathrm{O}$ regime militar sempre esteve claramente a serviço do grande capital, nacional e internacional; e, precisamente por isso, foi uma ditadura modernizadora - ainda que modernizadora- 
conservadora, no sentido de B. Moore Jr. (1985) -, que promoveu um intenso crescimento das forças produtivas e, em conseqüência, tornou mais complexa a ordem capitalista no Brasil. Era natural, então, que essa complexificação multiplicasse a diversidade de interesses e gerasse assim os pressupostos objetivos de uma sociedade civil forte, rica e articulada. A ditadura tentou, por diferentes meios, reprimir essa sociedade civil emergente, mas não foi capaz exatamente por não ser fascista no sentido 'clássico' - de domá-la e incorporála ao aparelho de Estado. Desse modo, a contradição fundamental que atravessou a história da ditadura foi precisamente a que teve lugar entre um Estado autoritário, que buscava cancelar e reprimir a sociedade civil, e o progressivo florescimento desta última, que o regime - não dispondo de instrumentos de mobilização como, por exemplo, um partido de massas de tipo fascista - era incapaz de evitar.

Essa contradição aparece de modo muito marcado no momento em que tem lugar o chamado 'projeto de abertura', com o qual o governo Geisel buscou enfrentar o início do declínio do regime, cujo primeiro sintoma foi a derrota do governo nas eleições parlamentares de 1974. A tentativa de evitar esse declínio levou à formulação de um projeto de abertura, a ser encaminhado 'pelo alto', com o objetivo de promover uma 'descompressão' fortemente seletiva, baseada na cooptação de alguns elementos moderados da oposição, mas, ao mesmo tempo, na exclusão e na repressão de seus segmentos mais radicais, em particular os representantes dos setores populares. ${ }^{23} \mathrm{Na}$ prática, contudo, a sociedade civil emergente terminou por promover um processo de abertura 'a partir de baixo', que certamente buscou se valer das novas condições geradas pela implementação do projeto 'pelo alto', mas que o transcendeu, indo bastante além dele, e que terminou assim por dar lugar a uma abertura bem mais radical do que a prevista no projeto originário do governo Geisel-Golbery.

Tomemos, como exemplo, o caso da anistia. No projeto de abertura, aceitava-se promover uma revisão caso a caso dos processos de condenação dos opositores do regime. O movimento da sociedade civil, o processo de abertura, terminou, porém, por levar a uma anistia que, se não foi tão geral e irrestrita como a oposição desejava, foi na verdade bastante mais ampla do que era previsto no projeto do regime. Com efeito, ela devolveu à legalidade e, mais do que isso, à luta política praticamente todos os líderes e todas as correntes de opinião existentes no país. ${ }^{24}$ Outro exemplo é dado pela lei que impôs o fim do bipartidarismo e abriu novas condições para uma reorganização partidária. $\mathrm{O}$ 
fim do MDB (Movimento Democrático Brasileiro), previsto no projeto de abertura como um modo de quebrar a unidade da oposição e de enfraquecê-la por meio do surgimento de vários partidos, terminou - graças ao processo de abertura - por voltar-se contra a ditadura: o multipartidarismo então surgido, ainda que limitado, deu expressão a novos interesses e criou novos sujeitos políticos, expressando melhor o pluralismo da nova sociedade civil. Além do mais, não desuniu a oposição, que continuou convergindo na luta contra a ditadura, como se tornou evidente, por exemplo, no movimento 'diretas-já'.

\section{[8]}

Malgrado todos os seus limites, a transição revelou, no 'para onde', um dado novo e extremamente significativo: o fato de que o Brasil, após mais de vinte anos de ditadura, havia se tornado definitivamente uma sociedade gramscianamente 'ocidental'. ${ }^{25}$ Cabe lembrar que, quando Gramsci define uma sociedade como ocidental, não o faz dizendo que ela seria algo simetricamente inverso ao que ele chama de Oriente. Para usar suas próprias palavras: "No Oriente, o Estado era tudo, a sociedade civil era primitiva e gelatinosa; no Ocidente, havia entre o Estado e a sociedade civil uma justa relação" (Gramsci, 2000:262). Portanto, não é que o Estado 'ocidental' seja fraco, débil; no 'Ocidente', o Estado também é forte, pode ser até mais forte do que numa situação 'oriental', mas o que caracteriza a condição 'ocidental' é que temos nela também uma sociedade civil forte e articulada, que equilibra e controla a ação do Estado stricto sensu. Não posso aqui argumentar mais detidamente sobre isso, mas me parece que o Brasil, já desde o final dos anos 1970, apresenta uma 'justa relação' entre Estado e sociedade civil.

Ora, se observarmos as sociedades 'ocidentais', veremos que elas apresentam dois 'modelos' principais de articulação da disputa política e da representação de interesses. Por um lado, há um modelo que poderíamos chamar de 'norte-americano', caracterizado (como ocorre em toda situação 'ocidental') pela presença de uma sociedade civil forte, bastante desenvolvida e articulada, mas em que a organização política e a representação dos interesses se dão, respectivamente, por meio de partidos frouxos, não programáticos, e através de agrupamentos profissionais estritamente corporativos. Por outro lado, temos um modelo que poderíamos designar como 'europeu'. Neste último, há uma estrutura partidária centrada em torno de partidos com base social razoa- 
velmente homogênea e que defendem projetos de sociedade definidos e diversos entre si; e temos um sindicalismo classista, que não se limita a organizar pequenos grupos profissionais, mas que busca agregar e representar o conjunto da classe trabalhadora.

No caso do modelo 'norte-americano', constata-se que são poucos os trabalhadores que se sindicalizam; os sindicatos representam somente os interesses de grupos relativamente restritos. Mas, quando esses grupos são fortes, quando representam ramos decisivos da economia, certamente obtêm resultados, ou seja, ganhos materiais para os seus filiados. Trata-se, portanto, de um padrão de organização sindical por vezes eficiente, mas estreitamente corporativo. Quanto à representação política, ela se centra em torno de partidos sem definição ideológica, que, na prática, atuam como frentes inorgânicas de múltiplos lobbies, isto é, de grupos corporativos. Falta a esses partidos uma base social mais ou menos homogênea e um projeto de sociedade que vá além da simples administração do existente. Naturalmente, há diferenças históricas e políticas entre o Partido Democrata e o Partido Republicano nos Estados Unidos; mas, independentemente de qual deles está no governo, as políticas postas em prática não mudam muito, já que ambos têm o mesmo projeto de sociedade. Portanto, não são partidos criados para fazer o que Gramsci chamou de 'grande política', mas se limitam a administrar o existente, a fazer 'pequena política' ${ }^{26}$ Esse modelo 'norte-americano' é, sem dúvida, o mais adequado à conservação do capitalismo, por causa das praticamente insuperáveis dificuldades que apresenta para a constituição de uma proposta hegemônica alternativa àquela dominante. ${ }^{27}$

No caso do 'modelo europeu', além de um sindicalismo classista e politizado, temos partidos que, ainda que nem sempre ideológicos, são certamente partidos programáticos. Para não falar na oposição entre os partidos comunistas e os partidos da 'ordem', não era difícil registrar, no Reino Unido, uma marcante diferença entre o Partido Trabalhista e o Partido Conservador, ou, na Alemanha, entre o Partido Socialdemocrata e a Democracia Cristã. As bases sociais de apoio desses partidos eram diferentes, daí por que eles representavam interesses sociais conflitantes e defendiam propostas políticas mutuamente excludentes. Os partidos comunistas e socialdemocratas, por exemplo, tinham sua base social preponderantemente concentrada no trabalho organizado, ao contrário dos partidos conservadores ou liberais, que, além de representarem as classes dominantes, construíam seu apoio de massa entre camponeses e camadas médias. Portanto, enquanto no 'modelo americano' temos partidos 
que defendem um mesmo projeto hegemônico de sociedade, no 'modelo europeu' havia uma salutar disputa entre propostas hegemônicas alternativas. Se, nos Estados Unidos, o socialismo foi sempre uma 'ideologia exótica', na Europa ele esteve freqüentemente no centro da agenda política. ${ }^{28}$

\section{[9]}

Essa breve digressão sobre modelos de sociedades 'ocidentais' tem um objetivo preciso: sugerir que o Brasil se coloca hoje (ou, mais precisamente, desde o fim da ditadura) diante dessas duas possibilidades de organizar a sua sociedade 'ocidental'. Na chamada Nova República (leia-se: no governo Sarney), graças a algumas características 'prussianas' ou 'pelo alto' de que se revestiu a transição, predominaram até mesmo, na nova ordem que se ia constituindo, elementos do velho modelo de Estado semi-oriental, como o clientelismo, o populismo, a tutela militar etc. Mas o problema que efetivamente define a conjuntura que se inicia com o fim da ditadura, e que de certo modo persiste até hoje, é o de saber de que modo irá se reorganizar a relação entre Estado e sociedade civil no Brasil.

Isso pode ser feito segundo um 'modelo americano' ou, mais precisamente, segundo um padrão 'liberal-corporativo'; nele, ao mesmo tempo que a vida econômica é deixada ao livre jogo do mercado, o conflito de interesses é também resolvido numa espécie de mercado político, no qual os grupos com recursos organizativos obtêm resultados, enquanto os que não dispõem de tais recursos são excluídos, sem condições de obter influência real. Estamos diante da proposta mais conhecida como 'neoliberal', que vem predominando em nosso país pelo menos desde o governo Collor. A alternativa a isso seria a reorganização de nosso peculiar 'Ocidente' a partir da agregação de interesses mais amplos, ético-políticos e não puramente econômico-corporativos (e volto a me valer da terminologia de Gramsci), possibilitando assim a construção de efetivas maiorias políticas, capazes de conduzir o país no sentido do aprofundamento de relações substantivamente democráticas. Por contraste ao neoliberalismo, poderíamos chamar de 'democrático-popular' esse modelo alternativo de organização da sociedade.

Se observarmos a vida brasileira dos últimos anos, veremos que esses projetos estão presentes no tecido social e têm marcado a agenda e o cenário políticos de nosso país. Não me parece casual que tenhamos duas centrais sindi- 
cais importantes, uma que se originou claramente inspirada num tipo de organização próximo do modelo europeu (a Central Única dos Trabalhadores - CUT) e outra que explicitamente quer imitar o modelo norte-americano (a Força Sindical); nem é casual que tenhamos tido partidos - particularmente o PT (Partido dos Trabalhadores), mas também outros partidos de esquerda - organizados segundo um padrão europeu, ao mesmo tempo que temos também partidos muito próximos do tipo 'norte-americano', como, por exemplo, o PMDB (Partido do Movimento Democrático Brasileiro), que hoje não passa de uma federação de diversificados interesses pessoais e regionais.

A presença simultânea de aparelhos de hegemonia próprios desses dois diferentes modelos revela, de certo modo, a persistência de uma indefinição quanto ao tipo de sociedade ocidental que vamos construir. Uma coisa, porém, é certa: a burguesia brasileira, em suas várias frações, já tomou consciência de que não pode recorrer mais, sem graves riscos, a uma pura dominação sem hegemonia. Precisamente a maturidade da sociedade civil, ou seja, o fato de que somos hoje uma sociedade 'ocidental', torna praticamente impossível o estabelecimento em nosso país de uma ditadura pela via militar: uma ofensiva da direita diante de um eventual avanço das classes subalternas não pode mais contar com a repetição do que ocorreu em 1964, quando em dois ou três dias se desbaratou todo o mecanismo de resistência das forças populares e triunfou um golpe mais ou menos incruento. Também se tornou bastante difícil uma retomada da hegemonia burguesa do tipo populista tradicional. $\mathrm{Na}$ verdade, o populismo foi possível num momento de crescimento econômico, no qual havia, em primeiro lugar, forte aumento da oferta de emprego - o que era uma poderosa forma de obter consenso dos governados - e, em segundo, uma razoável capacidade de redistribuição de renda. Estamos diante de uma conjuntura na qual nenhuma dessas duas características parece exeqüível; nem considero provável que o capitalismo brasileiro possa reverter essa situação. Por isso, é hoje muito difícil repropor uma hegemonia seletiva como aquela que vigorou na era populista.

Então, as duas fórmulas que a burguesia utilizou depois de 1930 para exercer sua dominação no Brasil - seja a ditadura aberta, seja o compromisso populista - me parecem pertencer, irrevogavelmente, ao passado. E, na medida em que a burguesia tem hoje consciência de que essas soluções são inviáveis, ela tem se esforçado por combinar sua dominação com formas de direção hegemônica, ou seja, por obter um razoável grau de consenso por parte dos governados. ${ }^{29} \mathrm{O}$ grande objetivo atual das forças do capital, no Brasil e no 
mundo, é consagrar a pequena política e a pseudo-ética do privatismo desenfreado como elementos fundamentais de um senso comum que sirva de base à sua hegemonia. É essa, precisamente, a face ideológica do neoliberalismo.

Portanto, a proposta hegemônica da burguesia é precisamente a de consolidar em nosso país o que antes chamei de 'modelo norte-americano'. Com efeito, este modelo pretende manter o velho corporativismo que caracterizou o Estado 'varguista', mas sob novas formas. Tomemos o caso das propostas de reforma sindical e de 'flexibilização' das leis trabalhistas. Já não se trata de incorporar os sindicatos ao aparelho de Estado, mas sim de permitir e tolerar, até de estimular e reforçar, um tipo de organização sindical 'livre', mas que não transcenda a defesa dos interesses particulares, corporativos, de determinadas categorias profissionais. Tais propostas, hoje postas na agenda política inclusive pelo governo Lula, têm como objetivo criar um tipo de 'liberdade sindical', e até mesmo de pluralismo, que conduziria a uma generalização do chamado sindicalismo 'de resultados'. Se essa 'reforma' vier a ser implementada, teremos a seguinte situação: quem é membro de sindicatos fortes faz contrato coletivo com a empresa, preserva até certo ponto os atuais direitos consagrados na CLT, mas quem não é sindicalizado ou pertence a sindicatos fracos perde até mesmo esses modestos direitos já conquistados. Se esse projeto de reforma vier a ser vitorioso, certamente alguns segmentos das camadas médias e até de trabalhadores do setor fabril podem obter alguns benefícios ou, pelo menos, conservar os atuais direitos. Tais segmentos sociais - além, naturalmente, do próprio empresariado - forneceriam a base social, o consenso, para esse tipo de projeto hegemônico 'liberal-corporativo'. Mas a grande maioria dos segmentos populares, particularmente os que não têm capacidade de organização, só teriam a perder com esse padrão de estruturação sindical e com essa 'flexibilização' das leis trabalhistas. É evidente que essa pequena capacidade de 'inclusão' - ainda menor do que aquela vigente no período populista - torna bastante problemática a estabilização, a médio prazo, de uma hegemonia neoliberal no Brasil.

No que se refere à organização partidária, esse projeto hegemônico da burguesia se tornaria real caso nosso país, seguindo também aqui os padrões norte-americanos, reduzisse a luta política a uma disputa eleitoral entre duas ‘elites’ partidárias que aceitam sem contestação o status quo. Como vimos, esse padrão, vigente nos Estados Unidos, começa a se implantar também na Europa. Durante um bom período após a ditadura, esse risco foi evitado no Brasil: o Partido dos Trabalhadores, surgido a partir dos movimentos sociais e pro- 
pondo uma estratégia socialista (ainda que não muito clara), manteve na agenda questões de 'grande política'. A ofensiva neoliberal encontrou no PT e nos movimentos a ele direta ou indiretamente ligados (CUT, MST, CPT etc.) uma forte resistência. Isso fez com que a conjuntura política brasileira, pelo menos até o final do segundo governo Cardoso, restasse ainda indefinida quanto à consolidação de um ou outro modelo de sociedade 'ocidental', embora já fosse claro o predomínio do modelo neoliberal.

Infelizmente, a chegada do PT ao governo federal em 2003, longe de contribuir para minar a hegemonia neoliberal, como todos esperavam, reforçou-a de modo significativo. A adoção pelo governo petista de uma política macroeconômica abertamente neoliberal - e a cooptação para esta política de importantes movimentos sociais ou, pelo menos, a neutralização da maioria deles - desarmou as resistências ao modelo liberal-corporativo e abriu assim caminho para uma maior e mais estável consolidação da hegemonia neoliberal entre nós. Estamos assistindo a uma das características mais significativas dos processos de 'revolução passiva', àquilo que Gramsci chamou de 'transformismo', ou seja, a cooptação das principais lideranças da oposição pelo bloco no poder. ${ }^{30}$

O risco de consolidação dessa hegemonia neoliberal, portanto, não se manifesta apenas nas propostas de reforma sindical e trabalhista a que já aludi. Torna-se também evidente na tendência, hoje dominante entre nós, no sentido de reduzir a disputa política a um bipartidarismo de fato, ainda que não formal, centrado na alternância de poder entre um bloco liderado pelo PT e outro pelo PSDB, que continuariam não só aplicando a mesma política econômica e social, mas também praticando métodos de governo semelhantes, que não recuam diante de formas mais ou menos graves de corrupção sistêmica. Estaríamos diante do triunfo entre nós da 'pequena política', ou seja, de uma agenda que não põe em discussão as questões substantivas da formação econômico-social brasileira. Não é casual o compromisso de ambos esses blocos em 'blindar' a economia, ou seja, em reduzir a uma questão 'técnica' e não política a definição daquilo que verdadeiramente interessa ao conjunto da população brasileira. Desse modo, o risco que corremos não é (como muitos afirmam) o da 'mexicanização' do nosso sistema político, ou seja, o da criação de um partido governamental único num regime formalmente multipartidário, mas seu 'americanalhamento', se me permitem o trocadilho, isto é, a criação de alternativas políticas que não põem em discussão as reais estruturas de poder econômico e político que vigoraram e vigoram na sociedade brasileira. 


\section{$\left[\begin{array}{ll}1 & 0\end{array}\right.$}

É importante sublinhar que as classes dominantes, conscientes da impossibilidade de propor a restauração ou conservação do velho Estado 'varguista' - que lhes serviu durante as seis últimas décadas de nossa história, mas que agora se revela imprestável numa era de financeirização e mundialização do capital -, têm uma clara proposta de redefinição do Estado. Adotando o modelo neoliberal, a burguesia (sobretudo o seu setor financeiro, hoje predominante) propõe não só o fim do intervencionismo estatal, com a transferência para o mercado da regulação da economia, ${ }^{31}$ mas também a desconstrução do velho corporativismo de Estado, no qual, em troca da renúncia à autonomia de suas organizações sindicais e políticas, eram concedidos legalmente aos trabalhadores alguns direitos sociais. ${ }^{32}$ Trata-se agora não só de capitular plenamente ao 'fetichismo do mercado' (o qual não pode ser 'contrariado' sob pena de 'ficar nervoso'), mas também de atribuir à 'livre negociação' (uma outra forma de dizer 'mercado') a definição dos direitos sociais dos trabalhadores, o que implica a desconstrução de muitos deles.

A esquerda deve ter uma proposta alternativa de reconstrução do Estado brasileiro. Infelizmente, em face do transformismo que converteu o PT e seu governo em eficazes agentes do neoliberalismo, a esquerda se enfraqueceu na correlação de forças que vigora no Brasil depois da transição, uma correlação que ainda permitiu, em 1988, a conquista de uma Constituição na qual estavam inscritos importantes direitos sociais, e que impediu, nos anos seguintes, a consolidação definitiva do novo modelo neoliberal de Estado. Isso não significa que tenham desaparecido do cenário político partidos e movimentos de esquerda, ligados às classes subalternas, que se opõem ao neoliberalismo. E, entre eles, são poucos os que julgam possível contrapor ao modelo de Estado proposto e implementado pelo neoliberalismo a simples restauração do velho Estado 'varguista'.

Como vimos, a característica talvez mais determinante desse tipo de Estado foi sempre ter se colocado a serviço de interesses privados ou, mais precisamente, dos interesses das diversas frações da burguesia. Ora, é precisamente essa a característica que o neoliberalismo quer reforçar, não só privatizando o patrimônio público na esfera da economia, mas também suprimindo os poucos direitos sociais conquistados pelos trabalhadores e inscritos na legalidade vigente. 
Por conseguinte, a principal tarefa da esquerda é lutar por um modelo de Estado que coloque o interesse público como principal norte de sua ação. Para isso, a esquerda deve começar redefinindo o que entende por 'público': ora, se 'público' não é sinônimo de Estado, já que a sociedade civil também tem uma indiscutível dimensão pública, tampouco é sinônimo de 'anti-Estado'. Está difundida entre nós uma leitura liberal do conceito de sociedade civil (rebatizada freqüentemente como 'terceiro setor'), segundo a qual tudo o que vem da sociedade civil é bom, enquanto tudo o que vem do Estado é ruim. Trata-se de uma visão equivocada, que nada tem a ver com o conceito gramsciano de sociedade civil. $^{33}$ Por um lado, pode haver uma sociedade civil hegemonizada pela direita; por outro, não é possível promover transformações sociais significativas sem a ação de um Estado controlado pelas forças populares. Portanto, a esquerda não pode abandonar a idéia de um Estado forte, mas deve agora combiná-la com a necessidade de tornar esse Estado permeável às pressões que vêm de baixo, ou seja, de uma sociedade civil que se torne cada vez mais hegemonizada pelas classes subalternas. Lamento não dispor aqui do tempo e do espaço para desenvolver mais amplamente o que me parece dever ser o projeto de Estado da esquerda na atual conjuntura.

\section{$\left[\begin{array}{ll}1 & 1\end{array}\right]$}

Para concluir, resumindo o que foi dito, penso que estamos diante da crise terminal de um tipo de Estado burguês: com efeito, tudo indica ser impossível restaurar ou conservar aquele tipo de organização estatal que conhecemos desde a década de 1930 e que - embora tenha sido responsável em grande parte pelo significativo desenvolvimento econômico ocorrido no Brasil nesse período - produziu entre nós, ao mesmo tempo, expressivos déficits de democracia e de justiça social.

Diante dessa crise, surgem duas propostas de redefinição do Estado. Por um lado, temos o que chamei de proposta liberal-corporativa, representativa dos interesses da burguesia, que consiste em desmantelar o pouco que há de público nesse Estado em crise e, como conseqüência, confiar ao mercado a regulação dos problemas sociais e econômicos. Trata-se, nesse caso, do aberto predomínio do privado sobre o público, um predomínio ainda maior do que aquele vigente no velho tipo de Estado 'varguista'. Por outro lado, temos uma proposta democrática, que representa os interesses das classes subalternas, centrada 
na reconstrução ou redefinição do espaço público; nesse novo espaço, o Estado certamente terá um lugar privilegiado, mas a dimensão do público deverá também incluir os organismos da sociedade civil, o que implica aumentar os mecanismos de participação, de socialização da política, lutando por construir os meios e os caminhos pelos quais o aprofundamento da democracia nos conduza não apenas a um novo modelo de Estado, mas também a uma sociedade de novo tipo, à sociedade socialista, única capaz de garantir as condições de um efetivo predomínio do interesse público na esfera da vida social e política.

\section{NOTAS}

${ }^{1}$ Para estas e outras categorias de Gramsci utilizadas aqui e adiante, remeto a Coutinho (1999).

${ }^{2}$ Cf. Lenin (1980), v.I, sobretudo p.29 e ss.

${ }^{3}$ Para o conceito gramsciano de 'revolução passiva', cf. Gramsci (2002), v.5, sobretudo p.209-210, 321-323, 328-332.

${ }^{4}$ Cf. Moore Jr. (1985), sobretudo capítulo VIII.

${ }^{5}$ Sobre isso, cf. Saes (1985), sobretudo p.181 e ss. Ainda que polêmicas, são muito fecundas as idéias expressas em Mazzeo (1989), sobretudo p.87 e ss.

${ }^{6}$ Identifico-me bastante com a análise da Revolução de 1930 feita por Vianna (1999), p.123 e ss. Cf. também, para a política econômica do período pós-1930, Ianni (1985:25-82).

${ }^{7}$ Um dos líderes do movimento de 1930, o mineiro Antonio Carlos, expressou muito bem a natureza desse movimento quando disse: "Façamos a revolução antes que o povo a faça."

${ }^{8}$ Ou seja: o Estado assumia a responsabilidade pelos setores que demandavam altos investimentos sem garantir lucratividade imediata, mas que eram fundamentais para o desenvolvimento dos outros ramos industriais. Com isso, transferia para o setor privado parte substancial da mais-valia gerada no setor público da economia. Isso significa que o Estado agia em favor do desenvolvimento do capital em seu conjunto.

${ }^{9}$ Uma posição similar seria assumida nos anos 1970 por Florestan Fernandes. Sobre isso, cf. Carlos Nelson Coutinho, "A 'imagem do Brasil' na obra de Caio Prado Júnior" e "Marxismo e 'imagem do Brasil' em Florestan Fernandes", in Coutinho (2000a:219-241 e 243265).

${ }^{10}$ Cf., em particular, Amaral (1981) e Campos (2001). Uma breve introdução a essa corrente de idéias está em Fausto (2001); encontra-se uma análise bem mais extensa em Medeiros (1979).

${ }^{11}$ Cf., entre outros, Vianna (1999:178 e ss.). 
${ }^{12}$ Cf. Cardoso (1975), sobretudo p.181 e ss.

${ }^{13}$ Uso 'sociedade civil' no sentido gramsciano, isto é, como uma arena da luta de classes, como o conjunto de aparelhos 'privados' de hegemonia que representam os interesses e valores de diferentes classes e segmentos sociais. Uma eficiente exposição desse conceito está na primeira parte do ensaio de Virgínia Fontes incluído nesta coletânea.

${ }^{14}$ Cf., entre muitos outros, Sodré (1976) e Ianni (1981).

${ }^{15}$ Essa consciência de classe foi bem registrada e analisada por Cardoso (1964), quando o então sociólogo mostra o interesse da burguesia brasileira em se vincular a um desenvolvimento de tipo 'dependente-associado'. Pena que, muitos anos depois, ao tornar-se presidente da República, Cardoso tenha se empenhado em promover precisamente esse tipo de desenvolvimento.

${ }^{16}$ De passagem, cabe observar que é exatamente esse o tipo de hegemonia exercido pela burguesia agrária cafeeira na República Velha, pela burguesia industrial durante a vigência do Estado 'varguista' e pelo capital financeiro depois do predomínio do neoliberalismo, sempre nos quadros de um bloco no poder formado em conjunto pelos vários segmentos burgueses.

${ }^{17}$ Não posso aqui me alongar sobre a questão, mas creio que o interregno representado pelo governo Dutra (1946-1950) foi uma tentativa - frustrada - de romper com o nacionaldesenvolvimentismo e voltar ao modelo livre-cambista da República Velha.

${ }^{18} \mathrm{O}$ que chamo de 'hegemonia seletiva' tem uma clara interface com o que Wanderley Guilherme dos Santos (1987:67 e ss.) designa como 'cidadania regulada'.

${ }^{19}$ No momento em que essas empresas já estão consolidadas e podem assim se tornar lucrativas, o capital privado passa a revelar interesse em adquiri-las, para assim lucrarem diretamente, sem a necessidade da mediação do Estado. Não há outra explicação para o processo de privatizações que, na última década, entregou ao setor privado, a preços de banana, grande parte do patrimônio público brasileiro, mediante generosos financiamentos concedidos pelo próprio Estado por intermédio de seus bancos de fomento.

${ }^{20}$ Uma brilhante análise marxista do fascismo é encontrada em Togliatti (1980).

${ }^{21}$ Sobre a 'doutrina de segurança nacional', cf. Alves (1989), sobretudo p.33-51.

${ }^{22}$ Dados empíricos que comprovam esse crescimento podem ser encontrados em Santos (1985:223-335).

${ }^{23}$ Não me parece casual que tenha sido precisamente no governo Geisel que o Partido Comunista Brasileiro - o qual, tendo se negado a aderir à luta armada, desfrutava então de significativa influência na frente das oposições, encarnada sobretudo no MDB - sofreu uma duríssima repressão, certamente a mais dura experimentada por ele durante todo o período da ditadura militar. 
${ }^{24}$ Uma restrição continuou a pesar sobre os comunistas. Embora lhes tenha sido possível criar uma imprensa legal, divulgar propostas, até realizar congressos, o PCB e o PCdoB permaneceram na ilegalidade até o governo Sarney.

${ }^{25}$ Para uma análise menos sumária do processo de transição e da 'ocidentalidade' brasileira, cf. Coutinho (2000b:87-118).

26 “A grande política compreende as questões ligadas à fundação de novos Estados, à luta pela destruição, pela defesa, pela conservação de determinadas estruturas orgânicas econômico-sociais. A pequena política compreende as questões parciais e cotidianas que se apresentam no interior de uma estrutura já estabelecida em decorrência de lutas pela predominância entre as diversas frações de uma mesma classe política" (Gramsci, 2000:21).

${ }^{27}$ Só nesse sentido os partidos de tipo norte-americano fazem 'grande política', já que como observa Gramsci logo na continuidade do texto antes citado - "é grande política tentar excluir a grande política do âmbito interno da vida estatal e reduzir tudo à pequena política" (Gramsci, 2000:21).

${ }^{28}$ O leitor terá observado que, ao falar do modelo europeu, usei sempre os verbos no passado. É que, na própria Europa, em função da atual expansão da hegemonia neoliberal no mundo inteiro, esse modelo está sendo progressivamente substituído por um modelo de tipo norte-americano. Parece-me que, cada vez mais, os partidos políticos europeus se assemelham aos norte-americanos (inclusive os partidos socialdemocratas e ex-comunistas), perdendo as suas características programáticas tradicionais; ao mesmo tempo, também o movimento sindical começa a assumir no Velho Continente alguns traços próprios de um sindicalismo de resultados. Mas essa é uma questão bastante complexa, que infelizmente não posso abordar aqui.

${ }^{29}$ Alguns importantes aspectos dessa luta burguesa pela hegemonia em nossos dias estão registrados e analisados em Neves (2005).

${ }^{30}$ Tenho dúvidas sobre a possibilidade de aplicar à atual conjuntura brasileira, iniciada com o governo Collor, a categoria gramsciana de 'revolução passiva'. Uma 'revolução passiva' implica algumas concessões às classes subalternas, como foi precisamente o caso do governo Vargas, do populismo em geral e até mesmo da ditadura militar (a qual, por exemplo, estendeu direitos previdenciários aos trabalhadores rurais e aos autônomos urbanos). Ao contrário, os últimos governos têm tido como meta apenas desconstruir direitos sociais já conquistados, o que talvez permita dizer que estamos numa época de 'contra-reforma' argumenta em favor desta posição Behring (2003, sobretudo p.171 e ss.). Mas, ainda que se trate de contra-reforma e não de revolução passiva, a justeza da aplicação da noção de 'transformismo' ao período que se inicia com o governo Cardoso e prossegue no governo Lula me parece inegável.

${ }^{31}$ A reivindicação de um Estado mínimo pelo pensamento neoliberal, na verdade, é mera ideologia. Por meio dos bancos centrais, da chamada política 'macroeconômica', são reguladas as linhas gerais de atuação do 'mercado'. José Paulo Netto (1993:81) observou corre- 
tamente: “A proposta do 'Estado mínimo' pode viabilizar o que foi bloqueado pelo desenvolvimento da democracia política: o Estado máximo para o capital".

${ }^{32} \mathrm{O}$ neoliberalismo nunca teve dúvida de que era preciso desconstruir esse modelo de Estado. Em seu discurso de despedida no Senado, em 1994, pouco antes de assumir a Presidência da República, Fernando Henrique Cardoso afirmou que um dos seus objetivos no governo seria destruir o que ele definiu como 'Estado varguista'.

${ }^{33}$ Sobre isso, remeto mais uma vez ao ensaio de Virgínia Fontes incluído nesta obra.

\section{REFERÊnCIAS Bibliográficas}

ALVES, M. H. M. Estado e Oposição no Brasil (1964-1984). Petrópolis: Vozes, 1989.

AMARAL, A. O Estado Autoritário e a Realidade Nacional (1938). Brasília: Câmara dos Deputados, Editora da UnB, 1981.

BEHRING, E. R. Brasil em Contra-Reforma. São Paulo: Cortez, 2003.

CAMPOS, F. O Estado Nacional (1935-1939). Brasília: Senado Federal, 2001.

CARDOSO, F. H. Empresário Industrial e Desenvolvimento Econômico no Brasil. São Paulo: Difel, 1964.

CARDOSO, F. H. Autoritarismo e Democratização. Rio de Janeiro: Paz e Terra, 1975.

COUTINHO, C. N. Gramsci: um estudo sobre o seu pensamento politico. Rio de Janeiro: Civilização Brasileira, 1999.

COUTINHO, C. N. A 'imagem do Brasil' na obra de Caio Prado Júnior; Marxismo e 'imagem do Brasil' em Florestan Fernandes. In: COUTINHO, C. N. Cultura e Sociedade no Brasil. Rio de Janeiro: DP\&A, 2000a. p.219-241 e 243-265.

COUTINHO, C. N. Democracia e socialismo no Brasil de hoje. In: COUTINHO, C. N. Contra a Corrente: ensaios sobre democracia e socialismo. São Paulo: Cortez, 2000b. p.87-118.

FAORO, R. Os Donos do Poder. 3.ed. rev. Porto Alegre: Globo, 1976.

FAUSTO, B. O Pensamento Nacionalista Autorirário (1920-1940). Rio de Janeiro: Zahar, 2001.

FERNANDES, F. A Revolução Burguesa no Brasil. Rio de Janeiro: Zahar, 1975.

GRAMSCI, A. Cadernos de Cárcere. v.3. Rio de Janeiro: Civilização Brasileira, 2000.

GRAMSCI, A. Cadernos do Cárcere. v.5. Rio de Janeiro: Civilização Brasileira, 2002.

IANNI, O. O Colapso do Populismo. Rio de Janeiro: Civilização Brasileira, 1968.

IANNI, O. A Ditadura do Grande Capital. Rio de Janeiro: Civilização Brasileira, 1981. 
IANNI, O. Estado e Planejamento Econômico no Brasil. 4.ed. rev. e ampl. Rio de Janeiro: Civilização Brasileira, 1985.

LENIN. O Programa Agrário. v.I. São Paulo: Ciências Humanas, 1980.

MAZZEO, A. C. Estado e Burguesia no Brasil. Belo Horizonte: Oficina do Livro, 1989.

MEDEIROS, J. Ideologia Autoritária no Brasil 1930/1945. Rio de Janeiro: Editora da FGV, 1979.

MOORE JR., B. As Origens Sociais da Ditadura e da Democracia. São Paulo: Martins Fontes, 1985.

NETTO, J. P. Crise do Socialismo e Ofensiva Neoliberal. São Paulo: Cortez, 1993.

NEVES, L. M. W. (Org.). A Nova Pedagogia da Hegemonia: estratégias do capital para educar o consenso. São Paulo: Xamã, 2005.

SAES, D. A Formação do Estado Burguês no Brasil (1888-1891). Rio de Janeiro: Paz e Terra, 1985.

SANTOS, W. G. dos. A pós-'revolução’ brasileira. In: JAGUARIBE, Hélio et al. Brasil, Sociedade Democrática. Rio de Janeiro: José Olympio, 1985. p.223-335.

SANTOS, W. G. dos. Cidadania e Justiça. 2.ed. rev. Rio de Janeiro: Campus, 1987.

SODRÉ, N. W. Brasil: radiografia de um modelo. Petrópolis: Vozes, 1976.

SUZIGAN, W. As empresas do governo e o papel do Estado na economia brasileira. In: SUZIGAN, Wilson. Aspectos da Participaşão do Governo na Economia. Rio de Janeiro: Ipea, 1976. p.77-134.

TOGLIATTI, P. Introdução ao Fascismo. São Paulo: Ciências Humanas, 1980.

VIANNA, L. W. Liberalismo e Sindicato no Brasil. 3.ed rev. e ampl. Belo Horizonte: Editora da UFMG, 1999. 
6. A Sociedade Civil no Brasil

CONTEMPORÂNEO: LUTAS SOCIAIS E LUTA TEÓRICA NA DÉCADA DE I 980

Virginia Fontes

objetivo deste trabalho é refletir sobre a história brasileira recente, partindo da conceituação gramsciana de sociedade civil. Sendo a sociedade civil - como conjunto de aparelhos privados de hegemonia - um dos terrenos da luta de classes em sociedades capitalistas modernas, sendo mesmo um dos espaços fundamentais da luta de classes em sociedades capitalistas, sob Estados de direito, com mercados eleitorais e conquistas (e reivindicações) democratizantes, sobre ela incidem nossas interrogações. De que forma se travaram as lutas nesse terreno? Que haja uma subalternização (educativa e disciplinar) dos setores rebeldes, fazendo-os tolerar a dominação de classes, o sabemos. Mas por que meios e como ocorre? Como é possível converter reivindicações sociais urgentes em apassivamento?

Analisaremos um período histórico com o intuito de rastrear a formação de alguns processos sociais dominantes na atualidade. Não pretendemos apenas expor fatos ou situações, mas compreender a dinâmica desse período, a inter-relação entre as diferentes lutas e suas conceitualizações, as idas e vindas, as tentativas e dificuldades reais com as quais se depararam aqueles que viveram e agiram - lutaram, sofreram e se inquietaram nesse período. Um dos objetivos é evidenciar o papel desempenhado por intelectuais, pensados como organizadores e elaboradores de uma reflexão sobre o mundo que os cercava. Para tanto, averiguamos a relação entre a consciência pensada e o processo vivido, suas possibilidades, as razões da emergência desse ou daquele conceito, seu significado, sua riqueza e seus limites, no contexto de seu nascimento e ao longo das práticas sociais que transbordam os limites do 
originalmente pensado e trazem novos problemas. Não se espere, aqui, o estudo singular desse ou daquele intelectual, pois privilegiamos o pensamento coletivo, para o qual muitos contribuíram.

Ainda que a avaliação resultante seja muitas vezes dura, não é nosso intuito um julgamento expost, uma crítica externada e fria. Precisamos decerto explicitar os graves deslizes que ocorreram, e o termo é empregado conscientemente, pois muitos intelectuais que formularam proposições e partiram para a ação prática dispunham de formação teórica substantiva. Mais ainda, contribuíram para a formulação de algo que, hoje, converteu-se numa impressionante alquimia de convencimento burguês. Pode-se mesmo aventar a hipótese de que estejamos analisando um dos momentos de construção da forma política contemporânea do imperialismo. Apesar disso, et pour cause, é necessário compreender, sentir a fundo as angústias e as esperanças que os animavam, pois o intuito de que estavam imbuídos era, muitas vezes, elevado e desprendido. Não basta confirmar o ditado popular a lembrar que de bemintencionados... o inferno está cheio. Se certamente a inquietude e a boa vontade são insuficientes para lastrear o conhecimento, precisamos refinar e agudizar nossos modos de pensar de maneira a nos tornarmos capazes de agir em ambos os terrenos - no conhecimento e no sentimento - para não repetir experiências similares. Mais ainda, precisamos estar aptos para enfrentar suas conseqüências e enfrentar os desafios atuais.

Este é um estudo comprometido com uma concepção histórica - a que compreende o processo histórico como o movimento das lutas de classes. Esses movimentos raramente são como exércitos se defrontando, em que cada um conhece bem seu campo e sabe qual o seu papel. Nas lutas de classes, muitas vezes, a maioria dos combatentes está tão ocupada em fabricar e polir armas, assegurar a intendência - plantar, colher, tecer, fiar, proteger e educar - dos próximos combatentes e cuidar dos feridos, que mal sobra tempo para se dar conta da batalha na qual estão mergulhados.

Evitaremos uma noção cristalizada de classe social, lembrando que ela remete às diferentes formas de extração do sobretrabalho em cada contexto histórico e integrando, também, a divisão internacional do trabalho. A maior evidência da existência de classes se apóia na exibição dos que detêm a propriedade, controlam o processo produtivo e, ainda, se apresentam como doadores de trabalho àqueles que, sem cessar, recriam o mundo sob as mais variadas relações de subordinação no trabalho. Por essa razão, não utilizaremos o termo 
'classe operária', procurando fugir da reificação de que se recobriu, ao estabelecer um tipo específico de trabalhador como se constituísse o conjunto da classe.

Como analisaremos um processo no qual se forjam e moldam as consciências, envolvendo intelectuais (no sentido amplo que Gramsci sugere, como organizadores e formuladores, como pensadores e críticos), num período de intensas transformações econômicas e sociais, a ênfase recai sobre a capacidade que tiveram - ou não - de atentar para as formas de organização das classes dominantes e do Estado. Enquanto existir capitalismo, ele produzirá classes dominantes e subalternos explorados. Se não formos capazes de analisar como ocorre a extração do sobretrabalho (econômica, social, política e culturalmente), perderemos de vista as classes dominadas e, assim, seremos presa fácil da nada generosa convicção de que acabaram as classes sociais e... a História.

\section{O Conceito de Sociedade Civil e sua Reformulação por Antonio GramscI}

Antonio Gramsci forjou, com o conceito de sociedade civil, um instrumento precioso de análise e compreensão das sociedades capitalistas avançadas. Ao mesmo tempo, porém, que superava de maneira decidida as características originais do conceito, atualizava, de forma modificada, diversos de seus significados, evidenciando os embates por meio dos quais construiu-se historicamente esse conceito e que, dada a permanência da sociedade capitalista, continuam a atravessá-lo. Compreender plenamente a sociedade civil, segundo Gramsci, demanda identificar alguns elementos de sua origem que reaparecem muito nitidamente nas lutas sociais contemporâneas.

O lastro original desse conceito - e sua riqueza primeira - deriva do pensamento contratualista de base anglo-saxônica, que explicou de maneira inovadora as instituições políticas, o Governo (o Estado), considerando-o como uma convenção humana (Manent, 1990). Seu maior expoente é Hobbes (15881679). Abandonando as formas ainda eivadas de pensamento religioso que perduravam na reflexão sobre a origem do poder político (embora já existissem diversas manifestações de pensamento laico sobre o exercício do poder, como Maquiavel), essa origem seria explicada a partir dos dolorosos atributos - naturais - da humanidade que a impeliriam a conter-se, a dominar-se por meio de um acordo tão ou mais violento do que a violência que o pacto deveria conter. Tratando-se de um contrato, era portanto realizado entre homens e sem 
interveniência de princípios ou agentes externos à humanidade. Esse acordo, decorrendo de uma natureza humana agressiva e marcada pela escassez (a fome e a insegurança), outorgaria a um dentre os homens (o Soberano) o atributo singular do exercício da violência e deveria assegurar a pacificação entre eles pela demarcação nítida de um único poder que deveria pairar - e exercer-se sobre todos.

Partindo da suposição de que poderes iguais no reino da natureza conduziriam os homens a uma situação de isolamento, selvageria e barbárie, de guerra de todos contra todos, propunha-se a instauração de um poder desigual, não-natural, humano, que deveria assegurar aos mesmos homens a pacificação, pela entrega das armas ao Soberano e pela obediência total que a ele passavam a ter de prestar, por serem os responsáveis pelo pacto.

Alguns pontos a comentar. Em primeiro lugar, esse pacto, derivando do sofrimento da natureza humana, é não-natural ou, mais propriamente, antinatural. Ele é um acordo entre os homens contra a natureza humana. A impossibilidade de viver de acordo com sua natureza os levaria a concluir um contrato que a limita, a reduz, a controla. A vida social seria, portanto, algo de antinatural. Introduz-se uma cesura entre o indivíduo, que permanece considerado como 'pura natureza', e o mundo da política, como o 'local de contenção' dessa mesma natureza.

Em segundo lugar, esse contrato antinatural derivaria diretamente de uma natureza humana má (genericamente faminta e cruel). Ele reuniria em si próprio o pior da natureza humana, sendo, por isso mesmo, um permanente monstro a espreitar cada um, mas um monstro necessário, capaz de conter, pela própria exacerbação de sua monstruosidade, as pequenas monstruosidades que habitariam cada um. O terceiro ponto a considerar é que o indivíduo que resulta desse pacto seria, ao mesmo tempo, um ser natural, no sentido forte do termo (pois, como natureza, ele é inalterável), e um ser de natureza contida, controlada, domesticada. A pacificação exigiria o emprego das armas, ou da violência (antes comum a todos), tornada privilégio apenas do Soberano ou daqueles investidos de tal poder.

O Estado - o contrato, o pacto, o Soberano - erguia-se pois como a antinatureza que, de fato, deveria regular, dirigir, controlar a natureza humana. E, ainda que paradoxalmente, competiria a esse Estado exatamente assegurar direitos cuja origem derivaria da natureza (vida, liberdade, propriedade). Num primeiro momento, a esse pacto corresponderia também o termo 'sociedade 
civil' como a entidade antitética ao estado de natureza. Os termos 'sociedade civil', 'Governo’ e 'Estado’ seriam quase equivalentes (Bobbio, 1992).

Por ser resolutamente um acordo entre homens, poderia também ser uma instância de pura racionalidade, uma vez que os elementos irracionais presentes na natureza estariam agora retirados de seu interior. Como o pacto se expressa e se completa pelas leis escritas, suas regras, conhecidas, poderiam pautar-se pela racionalidade (ainda que esta fosse concebida, sobretudo, como uma relação entre meios e fins). Assim, uma espécie de pirueta converteria o Estado de pura violência em expressão da Razão: a pior expressão da natureza humana teria produzido sua melhor forma. ${ }^{1}$

Obedecendo à lógica desse argumento, alguns momentos da vida humana teriam caráter político ou civil, isto é, recobertos pelo direito, que se diferenciavam daquela outra contenção da natureza humana assegurada por regras religiosas (o direito civil se sobrepunha ao direito canônico). Esses momentos coexistiriam com espaços 'naturais', como a família, as relações afetivas e, finalmente, com o momento econômico ou privado. Nestes, permaneceria reinando a natureza (a propriedade, a família e todas as relações não mencionadas pelo pacto).

Essa reflexão contém momentos extremamente tensos e suscita questões inquietantes. Em primeiro lugar, para consolidar a potência humana (o acordo político), reduz a natureza humana a elementos e sentimentos isolados, como se em algum período fosse possível conceber tais sentimentos de maneira exterior às formas de sociabilidade que constituem, necessariamente, os seres singulares. Em segundo lugar, contrapõe de forma rígida um mundo natural, terrível de sofrimento e de medo, a um outro mundo de medo (o pacto e a violência instituída), que seria sua contraparte inescapável. Em outros termos, sem Estado só restariam a barbárie e a selvageria. O Estado passaria a ser apresentado como uma necessidade - terrível - mas que derivaria da própria natureza humana, não sendo, por essa mesma razão, eliminável sem a imediata recaída na barbárie. Finalmente, considera haver uma permanente tensão entre os apetites 'naturais' e, portanto, não transformáveis, não modificáveis, e os códigos (leis, direito, em suma, a coerção do Estado), que devem, simultaneamente, mantêlos e contê-los.

Essa percepção tanto desconsidera a existência da capacidade formativa da sociedade, que instaura e produz indivíduos singulares com paixões e escalas de valores diferentes segundo os períodos históricos e as suas formas sociais de 
ser, quanto secundariza a capacidade transformadora da própria humanidade. Dessa forma, cristaliza um ser humano perverso e sua contraparte violenta e racional, o Estado. Num passo contraditório, um argumento brilhante naturaliza e 'des-historiciza' as próprias relações sociais que permite entrever...

Tais inquietações, grávidas de possibilidades, foram secundarizadas, uma vez que a concepção contratualista do Estado oferecia a muitos de seus seguidores a possibilidade de se desembaraçar dessas questões incômodas e enveredar pelo caminho dúplice então aberto - o da contraposição entre uma natureza humana estática e necessária (constituída de paixões vis, como o interesse, e pela salvaguarda da propriedade) (Hirschman, 1979) e uma 'institucionalidade' encarada como necessária e incontornável.

Desse conceito de pacto decorre logicamente algo para além do Estado, mas que dele difere - uma sociedade composta de homens 'naturais' que, entretanto, não mais se encontram em estado de natureza. Em outros termos, a existência do pacto supõe uma modificação desse conjunto de homens agora sob o domínio político (ou civil), que passariam do isolamento 'original', de uma situação selvagem ou bárbara, para uma situação contida, legal, com regras conhecidas. Aqui, a noção de sociedade civil desliza para o sentido oposto, tornando-se o par dicotômico do Estado, que a ele se contrapõe.

Locke (1632-1704) parte da reflexão hobbesiana, mas sua ênfase na propriedade o leva a ampliar (de forma ambivalente) o conceito de sociedade civil. De um lado, todos os homens integram essa associação (sociedade civil); de outro, somente os detentores de propriedade são dela integralmente membros. "Ora, essa ambigüidade permite a Locke afirmar que todos os homens são membros da sociedade, quando se trata de serem governados, e que somente a integram os proprietários, quando se trata de governar" (Macpherson, 2004:406). ${ }^{2}$

Uma tendência forte do pensamento liberal seria alternar-se entre o ponto de vista da sociedade civil (os interesses privados) e o da sociedade política, ou o Estado. A rigor, a maioria da reflexão de cunho liberal toma a primeira questão como axioma (a natureza humana seria o local da sociedade civil) e se dedica a organizar as formas do governo (e do Estado), as instituições, para que exerçam a função proposta - garantia da vida e da propriedade. Assim, os pensadores liberais dedicam-se cada vez mais a instaurar razões técnicas para o funcionamento do Estado, instaurando o que Nicos Poulantzas (2000) viria a denominar de maneira arguta como 'Estado Sujeito', portador de uma razão própria. 
Com largo uso na tradição anglo-saxônica, o termo 'sociedade civil' passaria a ser empregado como expressão similar à de progresso, com Ferguson e os escoceses, quando ganha ainda um outro significado: civilis não é mais adjetivo de civitas [no sentido de pertencente ao coletivo, ao equivalente latino do grego pólis], mas de civilitas. Sociedade civil significaria também sociedade civilizada (Adam Smith de fato emprega o adjetivo civilized), que encontra um quase sinônimo em polished"' (Bobbio, 1992:47).

Além dessas marcas fortes, o conceito de sociedade civil adquiriria outros atributos, de procedência francesa e alemã. $\mathrm{Na}$ vertente francesa, a crítica vigorosa de Rousseau, admitindo a lógica do contrato, contesta seus fundamentos. Mantendo-se no terreno da concepção de uma natureza humana, reveste-a de uma valoração positiva. Para ele, o advento da propriedade privada perverte e deseduca os homens, ressaltando seus piores instintos, os egoístas. O termo sociedade civil adquire uma conotação negativa, ao expressar o espaço da propriedade privada, elemento de corrupção da natureza humana.

Na linhagem alemã - em Hegel e, posteriormente, em Marx - o termo incorpora outras conotações, uma vez que a mesma expressão bürguerliche Gesellschaft pode assumir tanto o significado de sociedade civil (como uma base genérica da vida material e privada) quanto um significado mais preciso, da forma social característica da existência burguesa. Esse duplo sentido já limita a forma genérica ou abstrata do conceito. A concepção de Estado - e de sociedade civil ou sociedade burguesa - de Hegel é bem mais complexa, e sobre suas interpretações há numerosas controvérsias. ${ }^{3}$ Assim, nos limitaremos a algumas indicações. Hegel debate com os principais pensadores de seu tempo, com Kant, com os contratualistas, com Rousseau, com os historicistas e suas tendências irracionalistas.

Para Jean Hyppolite, Hegel ataca exatamente essa duplicidade entre o indivíduo - que seria natureza ou, mais propriamente, pura subjetividade - e o Estado - que deveria ser o momento superior da vida social. Para Hegel, porém, enquanto o Estado não se realizasse como eticidade, momento superior, ele restaria apenas como potencialidade. O Estado, em Hegel, figura como um ideal a atingir, uma possibilidade, o momento ético que deveria incorporar a liberdade individual, concebida não como um atributo isolado, mas como plena integração no todo social. Uma integração que, para ele, deveria ser ainda mais profunda do que a que observa no mundo platônico, quando a liberdade era, exatamente, o pleno pertencimento à coletividade, mas em que a noção de 
indivíduo ainda era frágil. Assim, o mundo moderno descortinaria uma nova possibilidade ética e coletiva, uma vez que, nele, a subjetividade - o indivíduo já estaria constituída historicamente (fruto do Cristianismo).

Ao mesmo tempo, Hegel percebe que, no Estado moderno, entre o indivíduo e o Estado se interpõe necessariamente um âmbito que ele denomina de sociedade civil (Die bürguerliche Gesellschaft). Nos cursos de 1805-1806, assinala a existência dessa sociedade civil, constituída pelo conjunto dos homens privados desde que se separam do grupo natural, a família, e ainda não têm consciência nítida de querer diretamente a sua unidade substancial, o Estado (como eticidade). Em 1821,

a sociedade civil será mais nitidamente caracterizada como um dos momentos da idéia do Estado no sentido amplo (o primeiro momento é a família, o segundo a sociedade civil, o terceiro o Estado no sentido restrito do termo, isto é, a vontade geral consciente de si mesma) (Hyppolyte, 1971:101)

A aspiração à liberdade individual, tal como o liberalismo a expressava, implicaria uma profunda limitação a uma eticidade plena. Se o Estado (a associação) reduzir-se a unicamente assegurar a proteção da propriedade, isto é, se o Estado se limitar e se reduzir à sociedade civil, à sociedade burguesa (Die bürguerliche Gesellschaft), se se limitar à segurança e à liberdade pessoal, o interesse individual passa a figurar como o único interesse efetivo, reduzindo e limitando o próprio indivíduo, que não mais reconhece seus laços efetivamente históricos e sociais.

o indivíduo em si só terá objetividade, verdade e moralidade se for um membro dele [Estado]. A associação, como tal, é ela própria o verdadeiro conteúdo e o verdadeiro fim, e a destinação dos indivíduos é levarem uma vida coletiva; e sua outra satisfação, sua atividade e as modalidades de sua conduta têm esse ato substancial e universal como ponto de partida e como resultado. (Hegel, Filosofia do Direito, apud Hyppolite, 1971:102)

Com Hegel, portanto, a sociedade civil torna-se, primeiro, burguesa, com uma localização histórica e social precisa. Em seguida, conserva uma valoração negativa, como expressão dos interesses particulares, e, finalmente, mantém uma relação tensa com o Estado. É parte dele, mas o limita, posto que sua universalidade permaneceria inconclusa enquanto a sociedade civil (Die bürguerliche Gesellschaft) não fosse por ele absorvida. É a partir dessas alterações introduzidas por Hegel no conceito de sociedade civil que se encontram as referências de Marx a esse conceito. 
A crítica de Marx e Engels modifica a definição de Estado hegeliana, que conservava um cunho mais filosófico. Trazem-na para um âmbito do processo histórico. $\mathrm{O}$ Estado é conceituado como elemento histórico, coligado à existência de classes sociais, não se traduzindo como um momento de universalidade efetiva. Embora se apresente como universal, reduz-se de fato a uma parcialidade travestida de universalidade, quando uma generalização do interesse dominante deve assumir a forma de ser de todos. Se em Hegel havia um horizonte prospectivo, momento da eticidade cujo pólo seria o Estado (a associação), em Marx a base ética e histórica (e ontológica) a partir da qual se poderia erigir a universalidade efetiva passa a ser o mundo da produção da vida, o mundo da atividade propriamente coletiva dos homens, o mundo do trabalho. Ambos conservam, todavia, a clareza de que a associação plena - e consciente - de todos os trabalhadores seria a condição (e o objetivo) de uma humanidade não mais cindida em classes. Para tanto, seria preciso superar o Estado.

A sociedade civil (Die bürguerliche Gesellschaft) continuava a ser concebida, portanto, como o terreno dos interesses. Estes, entretanto, ultrapassavam (e explicavam) os apetites individuais, compreendidos como interesses de classes, forjados no terreno da produção da vida material. Longe de ser o momento de universalização efetiva, o Estado para Marx e Engels expressa a generalização dos interesses dominantes. Estado e sociedade civil, separados pelo pensamento liberal, estariam aqui também reunidos, mas de forma distinta da reflexão hegeliana. A sociedade civil burguesa, entendida como o conjunto das relações econômicas, isto é, relações sociais de exploração, imbrica-se no Estado por ser este indissociável das relações sociais de produção. Seu papel é, exatamente, assegurá-las. Por isso precisa se apresentar sob a forma de 'bem comum':

cada nova classe que passa a ocupar o posto da que dominou antes dela se vê obrigada, para poder levar adiante os fins que persegue, a apresentar seu próprio interesse como o interesse comum de todos os membros da sociedade, quer dizer, expressando-o em termos ideais, imprimindo a suas idéias uma formulação generalizante, apresentando suas idéias como as únicas racionais e dotadas de vigência absoluta. (Marx e Engels, 1974:52)

Chegados a esse ponto, Marx e Engels praticamente abandonam o conceito de sociedade civil. Ainda que substancialmente modificado, ele conservava a idéia de contraposição entre sociedade e Estado (ou governo), obstaculizando a expressão do vínculo interno e necessário entre as relações sociais que produziam a vida e as formas de vivenciá-las. 
Antes de Gramsci, o conceito de sociedade civil admitia um sentido mais ou menos comum entre os diversos autores - designava, sobretudo, o âmbito dos interesses, do mercado, da concorrência. Para uns, valorizado como instância central a ser preservada, figurando a propriedade acima, inclusive, da vida (por esse viés, a propriedade e o mercado passavam a equiparar-se à própria civilização); para outros, como a expressão do predomínio, numa sociedade histórica precisa e delimitada, da sociedade burguesa moderna, de um individualismo que limitava e reduzia a própria individualidade, fazendo-a perder a consciência de seu pleno sentido, o do pertencimento a um processo histórico e social.

O conceito de sociedade civil é, portanto, recriado por Gramsci e, se retoma elementos precedentes, o faz de maneira radicalmente modificada. Como assinala Carlos Nelson Coutinho (1999), Gramsci empreenderá um desenvolvimento 'original' a partir dos conceitos básicos de Marx, Engels e Lenin, e toda a sua obra se filia portanto a essa tradição revolucionária. Conhecedor dos diversos usos dessa categoria, utiliza-se deles como uma plataforma para retomar as contribuições filosóficas das quais se nutre o marxismo e para identificar os problemas centrais da situação concreta e histórica, não apenas da Itália, mas das sociedades capitalistas desenvolvidas de seu tempo.

O fato de ter sido - pelas circunstâncias - obrigado a recaracterizar vocábulos para designar categorias já clássicas talvez tenha contribuído, inclusive, para que se libertasse do peso cristalizado (e banalizado) de certos conceitos, auxiliando-o a discernir o nervo central ao qual se referiam. Ao enfrentar abertamente, ademais, as derivações mecanicistas e simplificadoras do marxismo, potencializava o alcance de sua inovação.

Gramsci se interroga triplamente sobre a sociedade civil: 'como se organiza e se exerce a dominação de classes' nos países de capitalismo desenvolvido; 'sob que condições' os setores subalternos (dominados, explorados) empreendem suas lutas 'de forma a direcioná-las para a superação do capitalismo’; e, finalmente, retomando interrogações a partir de sua peculiar leitura de Hegel, reaproxima a reflexão sobre o Estado das formas da 'organização' social, num projeto político que almeja uma 'eticidade' (que não se limita à moral), portanto a plena realização dos indivíduos, exatamente porque passariam a perceber e viver intensamente sua participação na vida social (o tema da socialização plena, tão central em Marx). ${ }^{4}$

A sociedade civil, em Gramsci, é inseparável da noção de totalidade, isto é, da luta entre as classes sociais (Coutinho, 1994). ${ }^{5}$ O conceito liga-se ao 
terreno das relações sociais de produção, às formas sociais de produção da vontade e da consciência e ao papel que, em ambas, exerce o Estado. Liguori (2003) justamente relembra que, ainda que muitos autores apontem o conceito de sociedade civil como central na obra de Gramsci, a rigor o momento teórico mais denso e que permite a compreensão da sociedade civil é o de 'Estado ampliado'.

Parece-me que uma pista para compreender a profundidade da distância do conceito de sociedade civil - e, portanto, também de Estado ampliado formulado por Gramsci, e suas origens liberais, remete à relação entre Gramsci e Lenin. Este último havia fortemente enfatizado - a partir de Hobson e de Hilferding - o alcance da transformação pela qual passara o capitalismo na virada do século XIX para o século XX. O imperialismo - o predomínio do capital bancário sobre o capital industrial - demonstrava ser, numa de suas facetas, uma nova capacidade de 'organização' contraditória da própria burguesia (organização empresarial em larga escala, expansão da ciência possibilitada pela concentração monopólica, esquadrinhamento do mundo e das fontes de matérias-primas etc.). Gramsci aprofunda o tema das formas de organização, e se sua reflexão incide diretamente sobre a organização da dominação, o faz já incorporando o processo da luta de classes e de conquistas populares no âmbito do Estado capitalista.

Ainda que o uso do mesmo termo possa induzir algumas dificuldades, o conteúdo conceitual da sociedade civil, em Gramsci, se afasta resolutamente de sua origem, quando era contraposto ao Estado ou centrado no terreno do interesse, da propriedade e do mercado. Em Gramsci, o conceito de sociedade civil procura dar conta dos fundamentos da 'produção social, da organização das vontades coletivas e de sua conversão em aceitação da dominação, através do Estado'. O fulcro do conceito gramsciano de sociedade civil - e dos aparelhos privados de hegemonia - remete para a organização (produção coletiva) de visões de mundo, da consciência social, de 'formas de ser' adequadas aos interesses do mundo burguês (a hegemonia) ou, ao contrário, capazes de oporse resolutamente a esse terreno dos interesses (corporativo), em direção a uma sociedade igualitária ('regulada') na qual a eticidade prevaleceria (o momento ético-político da contra-hegemonia). ${ }^{6}$

Não há oposição entre sociedade civil e Estado, em Gramsci. Este seria o erro teórico liberal: 
dado que sociedade civil e Estado se identificam na realidade dos fatos, deve-se estabelecer que também o liberismo é uma 'regulamentação' de caráter estatal, introduzida e mantida por via legislativa e coercitiva: 'é um fato de vontade consciente dos próprios fins, e não a expressão espontânea, automática do fato econômico’. (Gramsci, 2000:47-48, destaques nossos)

Ao contrário, sociedade civil é duplo espaço de luta de classes, intra e entre as classes, por meio de organizações nas quais se formulam e moldam as vontades e a partir das quais as formas de dominação se irradiam também como convencimento. Tal como Lenin, Gramsci procura compreender o duplo movimento característico do capitalismo imperialista: a expansão concomitante ao aumento da concorrência e da tensão interna às classes dominantes, com os seus embates entre diferentes grupos e frações. Nas novas condições derivadas da conquista do sufrágio universal, Gramsci procura explicar a forma encontrada pelas classes dominantes para se assegurar a adesão dos subalternos. O convencimento se torna, doravante, uma tarefa permanente e crucial.

Esse convencimento se consolida em duas direções - dos aparelhos privados de hegemonia em direção à ocupação de instâncias no Estado e, em sentido inverso, do Estado, da sociedade política, da legislação e da coerção, em direção ao fortalecimento e à consolidação da direção imposta pelas frações de classe dominantes por meio da sociedade civil, fortalecendo a partir do Estado seus aparelhos privados de hegemonia. A dominação de classes se fortalece com a capacidade de dirigir e organizar o consentimento dos subalternos, de forma a interiorizar as relações sociais existentes como necessárias e legítimas. O vínculo entre sociedade civil e Estado explica como a dominação poreja em todos os espaços sociais, educando o consenso, forjando um ser social adequado aos interesses (e valores) hegemônicos.

Não há isolamento da sociedade civil com relação ao mundo da produção. Este constitui o solo da sociabilidade a partir da qual se produzem interesses e antagonismos, se forjam as agregações de interesses e vontades, se produz a subordinação fundamental. A sociedade civil é o momento organizativo a mediar as relações de produção e a organização do Estado, produzindo organização e convencimento. A sutileza de Gramsci reside em perscrutar as formas pelas quais se constroem, socialmente, essas vontades e se generalizam, em processos de luta social: 
o partido político, para todos os grupos, é precisamente o mecanismo que realiza na sociedade civil a mesma função desempenhada pelo Estado, de modo mais vasto e mais sintético, na sociedade política, ou seja, proporciona a soldagem entre intelectuais orgânicos de um dado grupo, o dominante, e intelectuais tradicionais; e esta função é desempenhada pelo partido precisamente na dependência de sua função fundamental, que é a de 'elaborar os próprios componentes, elementos de um grupo social nascido e desenvolvido como econômico, até transformá-los em intelectuais políticos qualificados, dirigentes, organizadores de todas as atividades e funções inerentes ao desenvolvimento orgânico de uma sociedade integral, civil e política’. (Gramsci, 2001:24, destaques nossos)

Ainda que muito conhecida, a próxima citação resume de forma clara o conteúdo do conceito gramsciano, apontando para a característica específica da sociedade civil como um dos planos superestruturais, distanciando-se, portanto, das concepções anteriores. A sociedade civil conecta o âmbito da dominação direta (a produção), por meio de sua organização e de seus intelectuais, ao terreno da direção geral e do comando sobre o conjunto da vida social, através do Estado.

Por enquanto, podem-se fixar dois grandes 'planos' superestruturais: o que pode ser chamado de 'sociedade civil' (isto é, o conjunto dos organismos designados vulgarmente como 'privados') e o da 'sociedade política ou Estado', planos que correspondem, respectivamente, à função de 'hegemonia' que o grupo dominante exerce em toda a sociedade e àquela de 'domínio direto' ou de comando, que se expressa no Estado e no governo 'jurídico’. Estas funções são precisamente organizativas e conectivas. Os intelectuais são os 'prepostos' do grupo dominante para o exercício das funções subalternas da hegemonia social e do governo político. (Gramsci, 2001:20-21)

A sociedade civil é o local da formulação e da reflexão, da consolidação dos projetos sociais e das vontades coletivas. Por meio de sua imbricação no Estado, assegura que a função estatal de educação - o 'Estado educador' - atue na mesma direção dos interesses dirigentes e dominantes, através da mediação dos partidos políticos, tanto os oficiais como os que, extra-oficialmente, difundem e consolidam as visões de mundo, a imprensa (ou a mídia). Esta assume diversas modalidades, agrupando diferentes tipos de intelectuais, desde os que forjam a 'racionalidade' adequada, sob a forma da reflexão técnica especializada (seminários, congressos, encontros), consolidando-o entre seus 'pares' por 
meio de periódicos especializados, até os repetidores, encarregados de sua vulgarização (transformação em 'dogmas') e ampla difusão.

\section{A Configuração da Sociedade Civil no Brasil, Transformações Sociais e os Usos DO CONCEITO: OS ANOS I98O}

No Brasil, a expressão 'sociedade civil' se difunde tardiamente na reflexão social, por volta da década de 1970. Seu ingresso no mundo social acadêmico, no entanto, seria marcado por polêmicas, ilusões e muitas dificuldades. As características do desenvolvimento capitalista brasileiro - com um viés coercitivo pronunciado, traduzido num monopólio seletivo da violência, exercida diretamente sobre os setores populares tanto pelo Estado quanto por forças paraestatais ou, ainda, diretamente patronais (Fontes, 2005) - não propiciaram uma tradição intelectual significativa em torno do papel da sociedade civil a partir da tradição anglo-saxônica ou liberal.

As traduções de Gramsci no Brasil, pela Editora Civilização Brasileira, ocorreriam exatamente no período do imediato pós-golpe de Estado e, ainda que tenham tido importância posterior fundamental, levariam um certo tempo a constituir-se como uma base sólida de leitura e de interpretação da vida social. A longa duração da ditadura - e, em especial, o período no qual vigorou plenamente o AI-5 (1968-1979), um efetivo torniquete imposto sobre as formas de contestação ou organização de cunho popular - parecia fazer desaparecer do horizonte as características da sociedade civil no sentido vivido por Gramsci, acoplada à socialização da política e ao aumento da participação popular. Dessa forma, as análises sobre as formas da política enfatizavam - como é compreensível - o peso do autoritarismo e da ditadura militar.

Uma das contraposições mais recorrentes tornou-se a que opunha 'civil' a 'militar'. Sendo uma acepção corriqueira, uma vez que o termo 'civil' é dicionarizado também como o "que não é militar nem eclesiástico ou religioso", 8 o senso comum passou a designar, de forma equivalente, 'regime militar' e 'Estado militar' (o que chegou a ser objeto de análises acadêmicas) e a contrapor, portanto, a essa ditadura, um regime civil.

Fenômenos internacionais também assumiriam relevo para as peripécias do conceito - e da prática - da sociedade civil nesse período: as lutas dos 
negros estadunidenses por direitos civis e contra o apartheid; a eclosão de diferentes movimentos sociais e a fragmentação dos antigos partidos comunistas nos países ocidentais, sobretudo a partir do maio de 1968 francês, e sua rápida internacionalização, atingindo principalmente o contingente estudantil (universitário). A expansão do contingente feminino no mercado de trabalho aprofunda as lutas feministas, que atingem um perfil cosmopolita sobretudo na década de 1970. Há ainda as grandes lutas pacifistas européias e seu corolário, com o movimento ambientalista.

No Brasil, reivindicações similares adotaram perfis distintos, pois os protestos de 1968 tiveram outro teor, em luta contra a ditadura. Não obstante, os sons do maio francês ecoariam também aqui, ao longo das décadas subseqüentes. Ainda no plano internacional, nos anos 1970 ocorreram importantes movimentos sociais, de base popular, em especial os movimentos de favelas, de bairros ou de quarteirões, traduzindo urgências populares que o acelerado processo de urbanização, em diferentes países, deixara de contemplar. Esses movimentos lastreariam uma longa série de estudos e reflexões, genericamente abrigados sob o rótulo 'questão urbana'?

No Brasil, vale relembrar momentos de incremento das lutas estudantis e populares em dois tempos - em 1968, com o crescimento de manifestações de rua e a expansão da resistência armada; e após um interregno de sangrenta repressão, a emergência de múltiplos (adjetivados como 'novos') movimentos sociais, com diferentes escopos, alcance e composição social.

A modernização capitalista acelerada - a ferro e fogo - sob a ditadura militar, entretanto, aprofundaria formas associativas - aparelhos privados de hegemonia - em grande parte ligadas aos próprios setores dominantes e expressando interesses diretamente corporativos que se organizavam como forma de ingressar na sociedade política. Esse processo não se inaugura sob a ditadura e remonta aos primórdios do século XX, ${ }^{10}$ consolidando-se entre 1937 e 1960 (Diniz, 1978; Leopoldi, 2000), experimentando forte impulsão a partir do período Juscelino Kubitschek e de seus grupos executivos. Após o golpe de Estado de 1964, houve uma importante expansão de associações empresariais por setores e ramos de produção a partir da década de 1970, as chamadas 'associações paralelas', que duplicavam a estrutura de representação empresarial oficial, de cunho corporativo-estatal (Boschi, 1979). ${ }^{11}$ A elas é preciso agregar outros tipos de organização, de caráter profissional, porém com abrangência nacional, em sua maioria preexistentes ao golpe de Estado e que teriam impor- 
tante papel na luta antiditatorial: Associação Brasileira de Imprensa (ABI), Ordem dos Advogados do Brasil (OAB), Conferência Nacional dos Bispos do Brasil (CNBB) (Alves, 1987) e a Sociedade Brasileira para o Progresso da Ciência (SBPC) (Pécaut, 1990).

O primeiro trabalho a realizar uma pesquisa documentada e consistente sobre a existência - e seus modos de articulação - da sociedade civil no Brasil, com conotação gramsciana, foi o de René Armand Dreifuss (1987), em 1964: a conquista do Estado. Resultante de pesquisa elaborada no final da década de 1970, como tese de doutoramento em ciência política na Universidade de Glasgow, Dreifuss demonstrava a existência, antes de 1964, de extensa rede de organizações empresariais que, não por coincidência, seriam agrupadas e dirigidas por pessoas muito próximas a (ou mesmo diretamente financiadas por) entidades estadunidenses, como o Instituto de Pesquisas e Estudos Sociais (Ipes) e o Instituto Brasileiro de Ação Democrática (Ibad). Mostrava, ainda, como elas se articulavam no âmbito do Estado, especificamente no terreno militar, em especial por meio da Escola Superior de Guerra. Essas entidades exerceram, na ocasião, intenso trabalho de preparação ideológica e cultural, com a realização e difusão de filmes, panfletos, tradução e publicação - a módico custo - de livros, e aparelharam-se para a efetiva conquista do Estado, em nome da 'democracia ocidental' e do 'livre mercado'. Ferozmente contrárias à expansão de direitos que as lutas sociais dos anos 1961-64 prefiguravam, utilizaram-se amplamente da difusão do medo (que efetivamente as assaltava) de qualquer alteração no estatuto da propriedade no Brasil, em especial na propriedade da terra. Foram auxiliadas pelo clássico social-conservadorismo católico brasileiro. ${ }^{12}$ Ainda que não tivessem diretamente realizado o golpe, Dreifuss demonstra como o organizaram e apoiaram e, assim, puderam imediatamente ocupar os postos centrais no Estado, reformatando-o segundo seus interesses. ${ }^{13}$

A reter alguns elementos que constavam da atividade dessa rede de associações: a forte influência norte-americana na difusão de estratégias e práticas (e recursos) de convencimento; o convencimento coligado à difusão do 'medo social', o que, diante do porte das desigualdades brasileiras, reforçava o caráter de 'classes perigosas' dos setores e reivindicações populares e procurava justificar o exercício de violência policial - e militar, no período ditatorial - sobre amplas massas populares ou sobre qualquer opositor; a conexão íntima realizada pela propaganda entre democracia, propriedade, mercado e hierarquia (esta, ressaltada sobretudo no ângulo militar, retomava entretanto as formas de obedi- 
ência coercitiva tradicionais); a presença e a proximidade com a alta hierarquia da Igreja Católica.

O trabalho de Dreifuss deixa entrever uma característica peculiar dos processos políticos brasileiros: a repressão seletiva havia favorecido a expansão de entidades de aglutinação de interesses e de convencimento social de cunho empresarial, ao mesmo tempo que havia dramaticamente constrangido e jugulado as iniciativas organizativas de cunho popular. Em outros termos, Dreifuss mostra o crescimento da sociedade civil no Brasil - como forma de organizar o convencimento social - ainda que esta fosse majoritariamente composta de setores das classes dominantes e não hesitasse na utilização aberta da coerção de classe.

As décadas de 1970 e 1980 foram especialmente ricas no que concerne à constituição de organizações, tanto de base empresarial quanto populares. As lutas sociais foram intensas, tornando complexos efetivamente os processos de direção e de construção de hegemonia. A compreensão do fenômeno foi, entretanto, algo obscurecida, pois a luta se travou também em torno de sua designação ou, mais propriamente, em torno do significado de 'sociedade civil'.

A simultaneidade da emergência de múltiplas organizações populares (com enorme potencial democratizante e, em muitos casos, com um perfil nitidamente anticapitalista) em luta contra a ditadura militar, assim como das expressões de descontentamento empresarial, contribuiria para uma extensão acrítica do termo 'sociedade civil'. Operava-se uma identificação entre forma de governo e Estado, na qual a recusa da ditadura passava a constituir-se, simultaneamente, numa recusa da luta no âmbito do Estado. Essa recusa, entretanto, de fato obstaculizava um projeto de superação do Estado capitalista, ao desconsiderá-lo como um momento importante da luta popular. Enaltecia uma atuação 'de costas' para o Estado, sem a intermediação de partidos, ou de organizações estáveis, consideradas como 'camisas-de-força' para tais movimentos.

Em boa parte, tais concepções expressavam duas situações diversas, que nelas se reconheceriam. De um lado, havia as disputas interempresariais em seguida às crises de 1973 e, sobretudo, de 1979. Com o Estado altamente endividado e o governo militar tendo sua legitimidade corroída, os recursos públicos seriam disputados pelos diferentes setores empresariais, até então contemplados. As principais entidades empresariais voltavam a criticar abertamente o tipo de intervenção realizada pelo Estado na economia e a demandar maior espaço de atuação privada (Freitas, 2000). ${ }^{14}$ Essa demanda não apenas demons- 
trava as lutas intestinas pelos recursos públicos, mas permitia ao conjunto do empresariado precaver-se com relação às lutas populares, que reivindicavam a extensão de serviços públicos (especialmente transporte, educação, habitação, saneamento e saúde).

De outro lado, ocorriam dois processos sociais simultâneos - a ampliação das universidades e o retorno dos exilados pela ditadura (intensificado a partir de 1979, com a Lei de Anistia). Dentre estes, muitos incorporaram ao longo do exílio o desencanto europeu com a experiência soviética, o que se expressou em muitos casos pela recusa aos partidos comunistas e, principalmente, à crispação dogmatizante das organizações comunistas que se autointitulavam marxistas-leninistas (ML). Desconfiavam dos partidos políticos e os viam como 'aparelhamento' das organizações populares. Mesclavam-se vertentes políticas de origens distintas, sob influência de setores da sociologia francesa, que abandonavam a reflexão social a partir de uma base classista. ${ }^{15}$

Quanto à expansão universitária, sobretudo de pós-graduação, esta favorecia a ampliação e o aprofundamento de pesquisas. Debates teóricos se mesclavam com questões políticas e, dentre eles, dois atravessaram as ciências sociais, chegando até os nossos dias. Trata-se de polêmicas longas travadas sobre questões cruciais para a compreensão da vida social. Em muitos momentos, entretanto, converteram-se em modismos acadêmicos, banalizando-se. A primeira polêmica girou em torno do estruturalismo - gerando um modismo antiestrutural difuso e que, a rigor, pouco tinha a ver com uma reflexão sobre estruturas sociais - e a segunda travou-se sobre os pesos relativos da influência externa (internacional) ou, ao contrário, dos processos internos (nacionais) para explicar as transformações ocorridas na sociedade brasileira. Tendenciosamente, a balança pendeu para a importância da análise rigorosa dos processos internos, o que permitiu um grande avanço e detalhamento das pesquisas. Deixou, entretanto, em segundo plano a reflexão sobre as formas de conexão entre esses processos - o que consolidou um certo isolamento e, mesmo, dogmatização dos setores que se mantiveram centrando suas análises no terreno internacional.

Com forte penetração acadêmica e universitária, uma parcela da produção sociológica, sobretudo aquela dedicada aos 'novos movimentos sociais', passou a criticar as abordagens calcadas em conceitos como classes sociais, considerando-as como não lastreadas na experiência imediata dos envolvidos ou como não suficientemente empíricas. Decerto, essa parcela encontrava nos meios populares - sobre os quais mais duramente se abateu a repressão e para 
os quais haviam sido restringidos os processos de formação - a 'comprovação empírica' de suas teses, uma vez que a interdição à reflexão sobre classes sociais - derivada da censura imposta pela ditadura - certamente produzira efeitos. Porém, nessa aproximação entre pesquisadores e movimentos sociais (resultante do contato militante ou da profissionalização das pesquisas) consolidava-se equivocadamente - uma concepção da 'recusa' do Estado, desconsiderando-o como um momento necessário. ${ }^{16}$

Essa postura dificultava a conexão entre as diferentes lutas populares. Os setores populares deviam enfrentar a repressão (política e cotidiana); percebiam e criticavam a seletividade social - agudizada sob a ditadura - dos serviços públicos, igualados genericamente ao Estado. Eram duplamente instados, de forma paradoxal, a permanecerem no terreno de suas reivindicações mais imediatas: de um lado, pela repressão; e, de outro, por esses novos acadêmicos, fascinados com o popular. Alguns autores saudaram esse procedimento como se ele traduzisse, enfim, a 'chegada ao pensamento democrático' no Brasil. Para estes, o aprendizado - ainda que forçado - de 'estratégias de racionalidade limitada' levava finalmente os intelectuais brasileiros a abandonar expectativas revolucionárias ('irracionais' ou 'utópicas') e a conviver com o mundo restrito da política institucional como horizonte insuperável. ${ }^{17}$

Esse foi o contexto de constituição das Organizações Não-Governamentais (ONGs). Protagonizadas por muitos ex-exilados, trariam uma modificação substancial nas formas de organização popular - apoiadas, em sua maioria, em fontes de financiamento internacional: não mais estavam coligadas a partidos e a um projeto social e político comum, mas a demandas específicas. Do ponto de vista de sua sustentação, em sua maioria, vinculavam-se a entidades ligadas às igrejas (cristãs), à benemerência internacional ou, ainda, a setores diretamente empresariais, fortemente internacionalizados (Dreifuss, 1986). A filantropia internacional apoiava diretamente a construção de ONGs, assim como a grande maioria de seus projetos.

As Comunidades Eclesiais de Base (CEBs), que tiveram papel importantíssimo na luta contra a ditadura, na constituição e na consolidação de uma associatividade de base popular, oscilavam entre um 'comunitarismo' messiânico e de cunho redentor e a politização desses movimentos por meio de uma reflexão sobre as bases sociais da dominação, especialmente desenvolvida pelos integrantes da Teologia da Libertação. ${ }^{18}$ Com a proximidade do término da ditadura, os segmentos mais conservadores da Igreja começariam a atuar no 
sentido de restringir a Teologia da Libertação, feito conseguido em 1985, com o voto de silêncio imposto pelo Vaticano (após relato do então cardeal Ratzinger) aos irmãos Leonardo e Clodovis Boff. O engajamento social religioso passaria agora a se realizar também por meio de entidades privadas, para o que contavam com acesso a fontes de financiamento católicas internacionais.

Por caminhos diferenciados, a 'concepção de autonomia' experimentava um importante deslizamento do sentido: de autonomia de classe, isto é, capacidade de construir uma contra-hegemonia, outra visão de mundo para além dos limites corporativos e do terreno do estrito interesse, passava a expressar a 'autonomia' de uma enorme variedade de grupos organizados em torno de demandas específicas. Boa parte da reflexão acadêmica sobre os movimentos sociais nos anos 1970 e 1980 enfatizava e sobrevalorizava a autonomia, sacralizando a fala imediata de cada grupo (ou organização social). Ela contribuiu, muitas vezes, para manter tais movimentos (os quais procuravam 'proteger') no terreno de luta imediata na qual se haviam constituído - moradia, saneamento, água, escola, saúde, transporte etc. Recusava reflexões de cunho classista - ou seja, que procurassem articular tais lutas de cunho corporativo a projetos sociais mais amplos e, nesse sentido, a educar de forma contra-hegemônica esses movimentos parcelares.

Outro ponto ainda desfiguraria a noção de autonomia - a questão do 'financiamento'. Ora, a autonomia de classe depende também de sua capacidade de autofinanciar-se, isto é, de ser capaz de prover a existência de suas próprias organizações, o que exige enorme inventividade e capacidade - teórica, prática e moral - para forjar uma nova sociabilidade, desvinculando-se das práticas dominantes de compra e venda de capacidades, das formas de subordinação e de hierarquia internas baseadas em cálculos de tipo empresarial. Em suma, da construção daquilo que Gramsci chama de 'novo príncipe', com forte teor organizativo e pedagógico. Nos anos 1980, a urgência das situações imediatas a sanar tomava a frente e, assim, esse tema ficou secundarizado.

Essas lutas mantinham, não obstante, forte cunho popular e, dessa forma, permaneciam nitidamente em terrenos contra-hegemônicos. Concentravam-se nas CEBs, nas associações de moradores, em pequenas associações anti-racistas, anti-sexistas, antiautoritárias e nas novas ONGs. O terreno comum seria o da luta antiditatorial e pela democracia.

No âmbito dos movimentos sociais, o que teve maior fôlego e um percurso peculiar foi o Movimento dos Trabalhadores Rurais sem Terra (MST), 
criado nessa década. Sofreria as influências difusas desses processos, mas simultaneamente produziria uma atuação bastante original. Sua principal reivindicação - a reforma agrária - foi considerada por alguns como um objetivo meramente integrativo ('reformista'), dedicado a minorar a situação de pobreza rural por meio de alguma distribuição de terras, cuja propriedade era (e continua) extremamente concentrada. Diferentemente dos demais movimentos sociais, entretanto, o MST precocemente enfrentou o extremo conservadorismo no meio rural e, com a coligação com os setores proprietários urbanos, contra qualquer alteração do estatuto da propriedade no Brasil. A defesa abstrata da propriedade unificava os setores dominantes, levando-os a apoiar o uso aberto da violência armada pelos proprietários rurais - ou a agir com extrema complacência em relação a ele. Desde seus primórdios, o MST defrontou-se com os fundamentos sociais de sua luta, tendo sido capaz de incorporá-los. Sua reivindicação - mesmo se ela se mantivesse no terreno corporativo, o que não foi o caso - colocava em xeque a aliança entre grandes proprietários rurais e urbanos que caracterizara o processo de expansão capitalista no Brasil. As características de sua base social também o levaram, precocemente, a dedicar-se a processos intensivos de educação e formação, consolidando uma atuação mais unificada e de base nacional.

A formação do Partido dos Trabalhadores (PT), em 1981, incorporaria a maior parte dessas diferentes tendências do campo popular, que seguiriam atuando em seu interior. Outros dois elementos devem ser considerados no PT, sobre os quais não nos estenderemos. A importância dos sindicatos na sua construção reforçava laços de cunho classista (de caráter marcadamente sindical) e atuava no sentido de estabelecer conexões, em primeiro lugar, entre os diferentes sindicatos e seus variados interesses corporativos e, em seguida, entre as miríades de movimentos sociais. Em segundo lugar, havia no PT a presença de organizações militantes com origem e formação política de cunho classista, que não perderam de vista a necessária crítica ao capitalismo e mantinham em pauta a reflexão sobre o papel do Estado e, portanto, da organização política. $\mathrm{O}$ Partido dos Trabalhadores continha em seu interior tendências não apenas diferentes, mas em diversos terrenos abertamente contraditórias.

É esse o terreno social e intelectual do primeiro surto de ONGs no Brasil, ocorrido na década de 1980. Elas tiveram como solo uma efervescência de movimentos sociais de base popular, os quais enfrentavam tanto o chamado 'entulho autoritário', isto é, a legislação arbitrária da ditadura (que só se transfor- 
ma em 1988, com a nova Constituição), quanto formas variadas de perseguição social (discriminação dos setores populares, alto grau de violência e repressão a todas as formas organizativas, inclusive por segmentos paramilitares), heranças tradicionais aprofundadas durante os anos da ditadura.

Desde 1968, uma das maneiras inventadas para burlar o controle direto dos órgãos de repressão ditatoriais havia sido a constituição de pequenos grupos de estudos (centros de pesquisa) e de educação (voltados para a formação popular), que orbitavam em torno de sindicatos, CEBs, partidos (a maioria proscritos) ou bairros populares. Na década de 1980, há um extraordinário incremento desse tipo de associação, com alterações de seu papel inicial, cujos desdobramentos serão mais visíveis na década de 1990.

Em pesquisa realizada em 1986, se autodefiniriam como organizações não-governamentais aquelas sem caráter representativo (diferindo, portanto, de associações de moradores ou sindicatos), que não integrassem grandes instituições (empresas, igrejas, universidades ou partidos). Do ponto de vista de seu discurso, elas se apresentavam majoritariamente como "estando a 'serviço' de camadas da população 'oprimida', dentro de perspectivas de 'transformação social”' (Fernandes \& Landim, 1986:47). Já então havia 1.041 ONGs constituídas, atingindo 24 unidades da federação e 213 cidades, sendo classificadas em três grandes tipos: aquelas 'a serviço do movimento popular (SMP)' (556 ONGs, voltadas para uma já grande diversidade de categorias sociais) e as voltadas para negros (234) e mulheres (251). Estas últimas tinham uma característica diferente, a de serem auto-referentes. Nestes casos, admitiam o elo militante com a auto-organização de negros e mulheres. Pode-se supor que, enquanto nas primeiras (SMPs) já se instaurava uma nítida separação entre o 'serviço' prestado e a população-alvo, nas segundas iniciava-se um processo molecular de transformação dos movimentos sociais nascentes em direção à sua 'onguização'.

O tipo de serviço prestado pelas ONGs era ainda tributário dos centros de estudos originais, sendo, em geral, caracterizado como 'assessoria', voltado para as áreas de educação e organização. A pesquisa ressaltava ainda a forte influência da Igreja Católica, uma vez que mais de um terço do total das ONGs declaravam possuir vinculação (formal ou informal) com as igrejas - o que levou os pesquisadores a concluir ser esta, "seguramente, a relação institucional privilegiada entre as ONGs" (Fernandes \& Landim, 1986:53). 
Ocorria uma transferência de militância para as áreas de assessoria e 'serviço' que, conservando um horizonte vagamente rebelde - a 'transformação social' -, era feita de maneira difusa. A influência religiosa provavelmente explica por que, embora atuando com sindicatos e com numerosos grupos de trabalhadores, sobretudo rurais, priorizava-se o termo 'opressão', reduzindo-se as reflexões sobre a exploração (e suas diferentes modalidades) nas próprias organizações de trabalhadores.

Esses novos intelectuais-militantes ligados às ONGs criticavam fortemente o intuito de partidos de falar 'em nome' dos movimentos sociais, justificando assim sua própria atuação; criticavam ao mesmo tempo as concepções de vanguarda, muitas vezes caricaturando-as. Desprezavam o isolamento das universidades, por não se misturarem às lutas populares. As ONGs atraíam, entretanto, grande número de pesquisadores universitários (elas se tornariam uma opção de profissionalização para muitos deles) que, paulatinamente, iriam se constituir nos 'educadores' desses movimentos - educadores de um novo tipo, pois sua função deveria se limitar, sobretudo, a reproduzir a própria fala dos envolvidos. Cumpriam um papel segmentador, educando e consolidando as lutas locais, por um lado, e, por outro, cristalizando-as e favorecendo sua manutenção naqueles formatos, uma forma inclusive de assegurarem sua própria reprodução como ONGs 'a serviço de...'.

Esse processo inquietava algumas entidades, que resistiam a essa 'onguização'. Muitas das associações e entidades forjadas sob a ditadura desconfiavam dos procedimentos de legalização e institucionalização como ONGs e resistiam fortemente à crescente profissionalização, denunciando a tecnicização dos serviços prestados por essas organizações (Fernandes \& Landim, 1986).

O mais importante a reter, na década de 1980, é exatamente essa 'modificação do perfil de uma parcela da militância', alterando o teor de sua participação. Reduzia-se o engajamento direto numa luta comum e crescia a 'oferta de serviços de apoio’ a lutas com cujas causas estariam, supõe-se, de acordo. O argumento central era a questão democrática, e era em nome da democracia que o conjunto dessas atividades se articulava.

Introduzia-se uma separação entre o 'assessor' (o técnico) e os militantes. Embora todos se apresentassem como 'militantes', falavam agora em nome da própria ONG. Doravante a autonomia fundamental seria a dessas entidades. Por essa cunha brotariam algumas características que se aprofundariam posteri- 
ormente. 'Consolidava-se a profissionalização da assessoria' prestada aos movimentos populares, ainda que conservando um cunho 'moral' de 'apoio' em prol da cidadania e de uma sociedade transformada, ou melhor, democrática. Aprofundando a rotação que transformava militância em emprego, os serviços profissionais prestados poderiam - e deveriam - ser remunerados conforme o mercado, de acordo com as condições de pagamento dos movimentos sociais ou, caso mais freqüente, por meio da orientação para obtenção de recursos em agências financiadoras. Uma nova especialização técnica se introduzia, a de 'agenciadores de recursos, nacionais e internacionais'.

Pela mesma brecha em que a filantropia se imiscuía na militância, nesse deslizamento da 'luta social' para estar 'a serviço de', 'desaparecia do horizonte a contradição entre fazer filantropia militante e ser remunerado por essa atividade’.

Outro ponto a reter é a extrema visibilidade que rapidamente elas adquiririam, assim como sua expansão. As ONGs estavam próximas dos movimentos sociais, participavam deles, assessoravam, apoiavam e contribuíam para sua sobrevivência. Confundiam-se, de certa forma, com eles, constituindo uma espécie de 'vanguarda' peculiar. 'Passariam a apresentar-se como a expressão mais adequada da sociedade civil.' Leilah Landim, em trabalho bem documentado, ainda que fortemente engajado nas ONGs, afirmou:

Desta forma, no bojo desses trabalhos próximos às igrejas, a tendências políticas e sindicais, a determinados movimentos sociais, as 'ONGs' criam 'sua autonomia'. Conformam-se, nesses processos, as propriedades particulares que caracterizam 'seus especialistas'. A 'democratização' do país, como se viu, é fator que contribui ainda mais para a conformação de espaços de atuação e de discursos 'específicos', surgindo com peso a idéia de 'sociedade civil' (combinando-se, no entanto, com a opção pelo 'popular') como 'vocação natural' das ONGs. (Assunção, 1993:384, destaques nossos)

Se a consolidação e o crescimento das ONGs transfiguravam seu momento fundador, a existência do Partido dos Trabalhadores, em seus primeiros anos, asseguraria a manutenção em outro patamar do tema da democracia, politizando efetivamente a sociedade civil de base popular, atuando como conexão entre os diversos movimentos populares, como fundamento para a ampliação do teor e do escopo das lutas sociais. Seu horizonte político - de cunho socialista, ainda que impreciso - se expressava por meio de um momento 'estatal', segundo a formulação de Gramsci, como um momento superior à 
reivindicação meramente corporativa, mas que ainda não se expressava como contra-hegemonia plena no plano ético-político (Gramsci, 2000). ${ }^{19}$ Teve forte atuação na defesa da universalização dos serviços públicos, da participação popular na formulação das políticas públicas, e assegurava a ligação, com a mediação do partido, de diferentes entidades populares.

Com o PT (e em alguns espaços universitários) inaugurava-se uma nova compreensão do fenômeno da sociedade civil no Brasil, ao lado de uma rápida difusão do pensamento de Gramsci. O tema mais candente, entretanto, seria o da hegemonia. Este conceito adquiria centralidade, dada a composição do próprio partido e de seus embates internos. Se, durante um longo período, a estruturação por tendências a disputar, abertamente, a condução política do partido (a 'disputa de hegemonia' no seu interior) permitiu a ampliação de debates e a explicitação de posições divergentes, também dificultou as condições para a construção de uma unidade de ação partidária, sobretudo no que dizia respeito às 'transformações sociais'. Esta ação passou a ser, crescentemente, figurada no interior do partido como o resultado de alianças mais ou menos efêmeras, asseguradas em encontros e congressos, trazendo para o interior do partido algumas das características do sistema representativo eleitoral brasileiro (acordos momentâneos, acertos de contas etc.) (Fontes, 2005). A importância do PT como pólo 'nucleador' dos movimentos sociais de base popular o instaurava como a 'expressão político-partidária dos segmentos subalternos da sociedade civil' e, por essa via, reforçava a leitura peculiar que se vinha gestando do conceito de sociedade civil - esta passou a ser percebida sobretudo como o terreno dos movimentos populares, olvidando-se do peso histórico e social das organizações de base empresarial.

Ocorria uma idealização do conceito - referido apenas ao âmbito popular - com posteriores conseqüências problemáticas. A sociedade civil, assim encarada, seria o momento socialista da vida social, o momento virtuoso. Por seu turno, o Estado era confundido ora com a ditadura, ora com a ineficiência e a incompetência derivadas de sua íntima conexão com o setor privado. Essa idealização fazia quase desaparecer do cenário as entidades empresariais.

Diversos segmentos empresariais e suas entidades representativas, procurando manter os procedimentos de dominação em plena efervescência de lutas populares antiditatoriais, retomariam o mote da prevalência da propriedade (e do mercado) sobre qualquer ingerência popular politicamente organizada que pudesse vir a controlá-la socialmente. 'Procuravam qualificar-se como a 
expressão racional da sociedade e reforçavam de forma vigorosa a contraposição entre sociedade e Estado, de cunho tipicamente liberal'. Tinham um programa para o Estado, que deveria modificar-se, mas para melhor atender a seus próprios anseios. Assim se expressaria o presidente da Federação das Indústrias do Estado de São Paulo (Fiesp), Luís Eulálio de Bueno Vidigal Filho, em 1986:

os senhores certamente já me ouviram falar que o Brasil é um país em que o 'Estado é forte e a sociedade é fraca'. Ao longo de nossa História, passada e recente, as instituições governamentais lograram obter um alto grau de controle, tutela e dominação sobre os outros segmentos da sociedade, fazendo com que as instituições sociais no Brasil crescessem sob uma patente fragilidade. Apesar de numerosa e economicamente poderosa, 'a classe empresarial não fugiu a essa dominação. A tal ponto que, até hoje, ela não detém um poder político compatível com seu poder econômico’. (Vidigal Filho, apud Mendez, 2004:163)

O empresariado brasileiro (considerado como todos os que atuavam no mercado brasileiro, independentemente de sua origem nacional) não era homogêneo nem tinha posições políticas idênticas. Nos anos 1980, os embates foram importantes também no interior das entidades patronais. Não obstante, ele conservara posições comuns rigorosas. Suas entidades, corporativas ou associativas (aparelhos privados de hegemonia), foram especialmente agressivas ao longo do processo constituinte (entre 1985 e 1988), tanto no sentido de reafirmar o seu papel quanto no de impedir (ou reduzir) as conquistas de cunho universalizante no âmbito da nova Constituição, na qual o "antiestatismo funcionou como proposta aglutinadora do empresariado e dos conservadores" (Dreifuss, 1989:218). As principais organizações empresariais que atuaram como 'pivôs político-ideológicos' nesse período foram a Câmara de Estudos e Debates Econômicos e Sociais (Cedes) ${ }^{20}$ o Instituto Liberal (IL), a Confederação Nacional das Instituições Financeiras (CNF), a União Brasileira dos Empresários (UB), ${ }^{21}$ a União Democrática Ruralista (UDR) e a Associação Brasileira de Defesa da Democracia (ABDD). ${ }^{22}$ Em 1987 se constituiria, por importantes empresários, o Movimento Cívico de Recuperação Nacional (MCRN), reunindo membros das associações anteriores mas compondo-as com auxiliares 'externos’, como Antonio Magaldi, da União Sindical Independente (USI), e diversos militares de alta patente. Nele estava Herbert Levy (empresário e dono da Gažeta Mercantil, então principal jornal voltado exclusivamente para o empresariado), e a entidade contaria ainda com o apoio de Roberto Marinho, proprietário da 
Rede Globo, de Victor Civita (Grupo Abril), assim como contribuições oriundas de grande quantidade de entidades empresariais. Sua diferença para as demais associações residia em que sua composição incluía grandes empresários, políticos e militares de alta patente, levando Dreifuss a defini-la como 'eixo de poder empresarial-militar'. ${ }^{23}$ A proximidade entre entidades empresariais e setores militares era já bastante estreita, coligando também interesses econômicos. Como exemplo, desde os primeiros dias de 1964 havia sido criado o Grupo Permanente de Mobilização Industrial (GPMI), revitalizado em maio de 1981, com uma reunião entre diretores da Fiesp e 24 oficiais das três armas, ocasião em que Vidigal Filho diria:

Hoje, o Grupo tem como objetivo providenciar, em estreita colaboração com as Forças Armadas, a implantação do maior número de indústrias capazes de produzir artigos de que necessitará o País, na hipótese de uma mobilização geral. Toda mobilização militar tem que ser fundamentada na indústria civil, que suprirá as necessidades das Forças Armadas. (Vidigal Filho, apud Mendez, 2004:160)

As entidades empresariais atuavam corporativa e politicamente como sociedade civil - no sentido gramsciano, como aparelhos privados de hegemonia - e participavam intimamente do Estado, inclusive no período ditatorial, mas apresentavam-se como 'sociedade' no sentido liberal, contrapondo-se ao Estado. Deslizavam facilmente de um a outro sentido, controlando passo a passo o processo constituinte por meio do Centrão, força política interpartidária que lhe dava suporte.

Travava-se uma luta acirrada no próprio espaço da sociedade civil, e não só pela constituição de variadas associações, organizações e entidades. Essa luta, de fato, espraiava-se para os partidos - em especial o PT. Em que pesem as contradições e dificuldades que a atravessam, ela começava, senão a ameaçar, ao menos a incomodar os postos avançados ocupados no interior do Estado pelos setores dominantes. A base de classe do partido havia simultaneamente avançado e se modificado. A CUT crescera - e muito - no cenário nacional nos anos 1980. Mantinha-se numa atuação combativa, concebendo o sindicato como parte de um conflito que opunha diferentes classes sociais. Com isso, procurava evitar que a ação sindical se esgotasse na luta reivindicativa corporativa (salários e condições de trabalho), apontando para a 'necessidade de uma alteração no bloco do poder, para que se pudesse contemplar os interesses dos trabalhadores'. Da mesma forma como no PT, o horizonte socialista era contemplado, 
mas seu conteúdo seguia indefinido (Boito Jr., 1999; Almeida, 2000, especialmente o capítulo VII, 'Democracia e socialismo').

Se a década de 1980 iniciara-se com uma retração nos movimentos grevistas, estes voltaram a expandir-se em 1983 e 1984. Já então, ao lado de uma relativa retomada das greves no setor privado, ampliava-se a combatividade no setor público. Após 1985 e, pelo menos, até 1991, ocorreria uma ascensão contínua das greves (Noronha, 1991; Mattos, 1998). ${ }^{24}$ Duas modificações importantes tinham lugar no âmbito sindical no final da década de 1980. Em primeiro lugar, a ascensão de Luiz Antonio de Medeiros à presidência do Sindicato dos Metalúrgicos de São (abril de 1987) e sua agressiva difusão de um sindicalismo de resultados, que contou com expressivo apoio das entidades patronais e da mídia, também patronal. Medeiros seria a ponta mais extrema da 'fala imediata' dos trabalhadores, recusando qualquer proposta (ou engajamento) que fosse além dos interesses mais imediatos. Em 1987, afirmaria, e seria divulgado pela Folha de S.Paulo, que "o capitalismo venceu no Brasil e os trabalhadores querem capitalismo". ${ }^{25} \mathrm{O}$ 'empresariamento' penetrava nas entidades sindicais por duas vias:

1) pela proximidade direta com as associações patronais (dentre as quais a Fiesp), que comungava com os propósitos de Medeiros e os apoiava, facilitando os meios para que carreasse recursos em vias da fundação ulterior da Força Sindical, explicitamente criada para combater a CUT; e

2) pela conversão pragmática do sindicalismo em expressão das urgências imediatas dos trabalhadores, o que permitia encarar o próprio sindicato (e, depois, as Centrais) como 'empreendimentos'.

A segunda modificação importante foi a ascensão do sindicalismo dos servidores públicos no cenário sindical. Aqui é necessário um parêntese, para compreender as ambivalências da questão dos serviços públicos no Brasil recente.

\section{Sociedade Truculenta, Estado Trunco, Serviços Públicos Truncados}

Os serviços públicos, no Brasil, sempre foram extremamente limitados e socialmente seletivos. A universalização de serviços públicos direcionados aos setores populares (como a saúde, a educação ou a previdência) jamais chegou a ser completa e, mesmo quando existia a possibilidade legal de universalização, 
foi limitada pelo número de servidores e pelos baixos investimentos nessas áreas. Setores de ponta do funcionalismo, altamente qualificados (geralmente da área econômica, alcunhados de tecnoburocratas, mas também as universidades), convivem com setores mal-remunerados, malformados e desprestigiados. Coexistem setores controlados por paternalismos e clientelismos com outros extremamente dinâmicos, organizados com métodos meritocráticos.

No conjunto das lutas historicamente levadas a efeito pelos diferentes segmentos do funcionalismo, muitas delas visavam desmontar as redes de controle quase senhorial sobre o setor público. Esse controle, político, era exercido por meio do ingresso de familiares (nepotismo), por agenciamento e troca de favores, e por patrimonialismos. Desde a década de 1940, as reivindicações do funcionalismo incluíam a exigência de concurso público universal e a ampliação de direitos sociais (educação e saúde, por exemplo).

As lutas propriamente sindicais do funcionalismo público brasileiro são recentes. Sua existência efetiva (mas ainda com caráter associativo e não formalmente sindical) remonta ao final dos anos 1970, sendo os sindicatos de funcionários legalizados apenas em 1988. Elas envolvem enorme complexidade, tanto pela dispersão e variedade de sua base (municipal, estadual, federal; autarquias e empresas públicas) quanto pelas contradições envolvidas em suas pautas de reivindicações, com uma imbricação entre questões econômicas e políticas:

a causa primeira dos movimentos grevistas [do funcionalismo público] era econômica e salarial, e por ocorrerem nas atividades públicas e estatais, ganhavam caráter diretamente político porque questionavam o poder e a legitimidade dos governos na sociedade. A greve era política também pelo lado da dimensão pública, no sentido de interferir diretamente nos interesses das classes que vivem do trabalho. (Nogueira, 2005:19)

Foge ao escopo deste trabalho a análise do sindicalismo do setor público no Brasil, assim como da riqueza de suas lutas. Esse sindicalismo teve uma importante trajetória nos anos 1980 e na década seguinte, quando defrontou-se com ofensivas extremamente agressivas, a começar pelo massacre de grevistas em Volta Redonda (governo Sarney), seguido pela massa de demissões entabulada no governo Collor de Mello e pela truculência exercida pelo governo Fernando Henrique Cardoso contra os petroleiros, no episódio da defesa da Petrobras.

Nossa interrogação aqui - para a qual estamos sugerindo, menos do que respostas, alguns eixos exploratórios e provisórios - é: como foi possível suscitar, na década de 1990, a adesão popular (ativa e passiva) para o desmonte de 
serviços e de conquistas sociais que diziam diretamente respeito a essa mesma população? Sabemos que a coerção teve importante papel (e mencionamos alguns de seus episódios); sabemos também que a coligação entre os aparelhos privados de hegemonia de base empresarial, sob o predomínio neoliberal, utilizou-se de uma formidável máquina de propaganda, em todos os meios de comunicação, atingindo inclusive os estudantes por intermédio de revistas como a Nova Escola, da Editora Abril. Entretanto, essa 'máquina' de marketing político parece-nos ter encontrado apoio em algumas dificuldades e aspectos ambivalentes do setor público brasileiro (e de suas lutas), que constituiriam pontos de fragilidade a serem fartamente explorados.

Muitas vezes, temas de interesse geral constituíram parte das pautas de reivindicação nos momentos de lutas salariais - vale lembrar, aliás, que os funcionários públicos, sobretudo os de baixo escalão, foram duramente penalizados no plano salarial. Embora com baixos salários, contavam com contratos permanentes e baixo risco de demissão, o que os diferenciava dos demais assalariados. Isso seria explorado a fundo pelo empresariado e pela mídia, na década de 1990, enquanto eles próprios fomentavam o desemprego.

Dadas as diferenças internas entre o funcionalismo público, a demanda de isonomia entre seus diversos setores era legítima, mas resultava em duas frentes, com alcance muito desigual. Num primeiro patamar, constituíam o solo imediato (corporativo) a partir do qual se descortinava um horizonte político mais amplo, pela constituição de carreiras públicas efetivamente nacionais, generalizando políticas antes restritas a determinadas regiões. Por essa via, chegaram a propor políticas públicas de um nível mais elevado, envolvendo toda a federação, formulando efetivos projetos nacionais. A aprovação de um Regime Jurídico Único (RJU) apontava para essa direção. Num segundo patamar, arriscava-se a permanecer em lutas de equiparação salarial e de eqüidade interna que, por vezes, descurava da universalização dos direitos a que faziam jus as demais camadas trabalhadoras da população. A centralidade adquirida pelo tema da isonomia - secundarizando a questão nacional que envolvia - encapsularia no âmbito das relações entre o próprio funcionalismo, de maneira corporativa, temas populares que extrapolavam, e muito, esses limites.

Em outra direção, a modernização do setor público, derivada de imposição governamental, de demandas setoriais ou de lutas dos servidores, trazia uma das condições de possibilidade de sua universalização: o acesso universal por concurso ('meritocrático') e a eliminação paulatina dos controles diretos - 
patronais e políticos - sobre o conjunto do funcionalismo poderiam possibilitar a extensão dos direitos sociais. Num primeiro momento, entretanto, eventuais vantagens da modernização pareciam incidir apenas sobre o próprio ambiente de trabalho do funcionalismo, como planos de carreira, melhorias salariais e reconhecimento profissional.

Essas dificuldades internas favoreceriam a renovação das estratégias de neutralização (ou de cooptação) de algumas parcelas do funcionalismo. Desde 1964, a intervenção sindical realizada pelo golpe de Estado potencializara não apenas seu caráter assistencialista, mas a duplicação de suas funções por meio da oferta de serviços médicos e dentários aos sindicalizados. Induziu, portanto, a uma privatização peculiar, sindical, de serviços públicos. Dentre as empresas públicas, algumas contavam com caixas de previdência própria, complementando as aposentadorias de seus funcionários, assim como asseguravam diversos outros benefícios (saúde, tratamento dentário, auxílios diversos). Esse procedimento, implantado anteriormente, era limitado a algumas entidades, mas já operava como profundo diferenciador no interior do funcionalismo e, ainda mais fortemente, com relação aos direitos trabalhistas dos demais assalariados.

A demanda de isonomia era respondida com o aceno à eventual extensão de complementações previdenciárias (via caixas ou fundos previdenciários) para os setores com maior capacidade de pressão no âmbito do aparelho de Estado. Em vez da luta universal pela transformação no sistema previdenciário nacional, uma lógica perversa: as ofertas de vantagens não-salariais a segmentos do funcionalismo público dessolidarizava parcela do próprio funcionalismo do conjunto dos serviços públicos e estabelecia, para os próprios funcionários, o setor privado como referência de 'qualidade', distinguindo-os ainda mais da massa trabalhadora.

No final dos anos 1980, acrescentou-se a expansão dos vouchers, como os 'tíquetes-restaurante', por meio dos quais empresas terceirizadas substituíam os bandejões coletivos (ao lado de intensa propaganda fomentando o individualismo), e o 'seguro-saúde' (empresarial ou individual): empresas terceirizadas vendiam atendimento médico propagandeado como primeira necessidade, diante da má qualidade e das dificuldades realmente existentes nos serviços públicos de saúde. Outros vouchers, como 'vale-creche' ou 'vale-educação', para alguns segmentos do funcionalismo, garantiam a escolarização de suas crianças, a salvo das dificuldades experimentadas pela maioria da população nas escolas públicas. 
Dado o contexto das desigualdades sociais brasileiras, um alívio, ainda que pequeno, das condições de trabalho no funcionalismo (mantidas as mesmas dimensões do serviço público) atingia mais direta e imediatamente setores médios do que os setores populares. Os concursos eram - e continuam - de difícil acesso, favorecendo as familias em condições de oferecer complementos pagos de ensino aos seus filhos. Estes, em muitos casos, jamais necessitaram do serviço público (especialmente nas áreas de maior demanda popular, como educação e saúde). Melhorias profissionais e salariais do funcionalismo não revertiam imediatamente (nem o poderiam, de fato) em melhoria social para as grandes maiorias.

Finalmente, um último e trágico dilema. Na década de 1980, ocorria uma forte tensão entre a extensão dos serviços públicos e o nível de qualidade requerido. A partir dos anos 1990, a dialética entre quantidade e qualidade tenderia a pesar mais substancialmente para o lado da defesa da qualidade do que já existia do que para a extensão e generalização dos serviços públicos. ${ }^{26}$

É compreensível, pois, que não houvesse uma predisposição popular à defesa dos serviços públicos no Brasil. Sequer o sindicalismo de funcionários públicos, por sua variedade e heterogeneidade, balizou todas as suas lutas nessa direção, tendo aceitado (e demandado, em algumas vezes) complementações não-salariais que desqualificavam o conjunto dos serviços públicos (escola, creche, saúde, alimentação, transporte).

Esse parêntese procurou ajudar a dimensionar a extensão das dificuldades com as quais deveriam se afrontar os movimentos populares na década de 1990. Ressalte-se, todavia, que esses obstáculos, herança da trágica tradição social brasileira, encontravam lutas aguerridas por sua superação, tanto por parte do próprio funcionalismo quanto por parte de uma composição heteróclita de movimentos sociais e, ainda, por parte do PT. Em algumas áreas constituíramse importantes - e socialmente relevantes - movimentos sociais pelos serviços públicos, próximos das lutas sindicais, em prol da generalização de serviços essenciais, dentre os quais vale mencionar a saúde, o saneamento e a educação.

\section{Sociedade Civil e Corporativismo}

A década de 1980 é crucial para a compreensão da sociedade civil no Brasil atual. O horizonte contra-hegemônico capitaneado pelo PT encontrava seu ponto de união em torno de um projeto democrático, com teor anticapitalista, mas com matizes fortemente corporativos. Impulsionada pelas vitórias que a 
base sindical operária (sobretudo metalúrgica) conseguira, parcela inclusive de setores mais radicais no interior do partido aderia aos modos de fazer de tipo corporativo, pelos resultados que esse tipo de atuação permitira entrever.

A questão corporativa, aliás, se presta a muitas confusões. O termo deriva de um sentimento de pertencimento gerado entre artesãos realizando um mesmo ofício (o esprit de corps) e, por extensão, passou a remeter às associações que unificavam os integrantes de diferentes corporações de ofícios. Gramsci apresenta o momento corporativo (que chamaremos de sentido 1) como a capacidade de associação e de organização de um número maior ou menor de setores sociais, mas ressalta sua principal limitação quanto à consciência da totalidade: a de permanecer no terreno dos interesses, no terreno do 'egoísmo de grupo'. No Brasil, o termo 'corporativo' assume uma segunda conotação, para indicar o atrelamento ao Estado imposto aos sindicatos de trabalhadores (sentido 2), marcas da influência fascista na organização sindical nacional.

Lutas sindicais costumam ter forte conotação corporativa (1), expressando exatamente o chão social a partir do qual emergem. No segundo sentido, entretanto, o próprio patronato lutaria, na Constituinte, para manter o corporativismo que limitava a associatividade dos trabalhadores. Antonio Oliveira, empresário, presidente e coordenador-geral da União Brasileira de Empresários (UB), e Albano Franco (presidente da Confederação Nacional da Indústria - CNI) uniram seus esforços nessa direção, apoiando alguns setores sindicais e isolando tanto os sindicalistas contrários ao corporativismo estatal quanto dirigentes industriais que admitiam rever a legislação. ${ }^{27}$

A sociedade civil apresentava-se como riquíssima arena de luta de classes, ainda que muitos não quisessem mais pensar nesses termos. Boa parte dos setores populares se debatia com dificuldades de organização, sobretudo quanto a recursos, o que favorecia a expansão de ONGs, atuando por meio da captação de recursos externos e, em seguida, de fundos públicos.

A capacidade de aglutinação - de agir como um 'estado-maior' - do PT e a multiplicidade de movimentos que coordenava ameaçavam desestruturar os esquemas de dominação tradicionais, obrigando a uma recomposição, realizada às pressas com Collor de Mello e, depois, finalmente azeitada com a ascensão de FHC ao papel de porta-voz educado das burguesias brasileiras.

Essa não foi, portanto, uma década perdida. Alguns temas populares tornaram-se agenda obrigatória, quase senso comum no cenário social e políti- 
co nacional, trazidos por essa disputa acirrada entre projetos sociais diferentes, ainda que o discurso petista hesitasse em sua própria definição. Igualdade (na denúncia das desigualdades sociais); solidariedade (objetivando ir além dos limites corporativos, no sentido 1); dependência e dívida externa; urgência de amplas reformas sociais e universalização das políticas públicas, com ênfase na saúde e na educação. É exatamente sobre elas que a luta seria travada na década de 1990.

A luta atravessava a sociedade civil, com a expansão de aparelhos privados de hegemonia de cunhos variados, cuja proximidade com as classes fundamentais nem sempre era muito nítida - assim como ambivalentes eram as formas de conceituá-la. A expansão das ONGs contribuiria para uma diluição importante do significado do engajamento social e para embaralhar a percepção da real dimensão da luta que se travava. As ONGs - e por extensão boa parcela do PT - sacralizavam a sociedade civil como um momento virtuoso, com o risco de velar a composição de classes sociais em seu interior.

A própria democracia seria também idealizada como o reino de uma sociedade civil filantrópica e cosmopolita, para a qual todos colaborariam, sem conflitos de classes sociais. O tema da revolução se esfumaçava num futuro longínquo e, quiçá, almejava-se não fosse mais necessário. Com a queda do muro de Berlim e, nos anos 1990, o desmonte da União Soviética, teria novos desdobramentos.

O projeto de contra-reforma empresarial, entretanto, fortemente amparado em aparelhos privados de hegemonia (e na mídia), se consolidava e se aproveitaria dessas contradições para seduzir os setores populares contra seus próprios direitos.

\section{NOTAS}

\footnotetext{
${ }^{1}$ Essa caracterização permite compreender como, posteriormente, a expressão será retraduzida em 'mão invisível do mercado' ou em conversão de 'vícios privados em benefícios públicos'. ${ }^{2}$ Em Macpherson (2004), ver capítulo sugestivamente intitulado 'Ambigüidades da sociedade civil', p.407-412.

${ }^{3}$ A respeito das polêmicas em torno da obra hegeliana, ver Losurdo (1998).

${ }^{4}$ Esse tema é reiteradas vezes expresso nas cartas escritas por Gramsci a partir da prisão, inclusive expondo um terreno delicado, o da configuração psicológica. Cf. Gramsci (2005, 2v., passim).
} 
${ }^{5}$ Ver, especialmente, 'O ponto de vista da totalidade e as ciências sociais particulares' (Coutinho, 1994:91-101).

${ }^{6}$ Poder-se-ia considerar que essa categoria 'ético-política' expressa dois momentos com qualidades opostas: o patamar de generalização do interesse de uma fração dirigente das classes dominantes, consolidando um bloco histórico dominante e hegemônico, e seu oposto, a condição de superação do mundo dos interesses por meio da contra-hegemonia. Essa dupla percepção não reduz, a meu juízo, o descortino e a validade dos conceitos gramscianos, uma vez que demonstra a enorme capacidade de perceber as condições concretas (a hegemonia burguesa) e de apontar para formas contrapostas (a luta de classes) no sentido de sua superação. Ver, a respeito do duplo uso das categorias gramscianas, Anderson (1986).

${ }^{7}$ Como o mostra Vianna (1999).

${ }^{8}$ No Dicionário Eletrônico Aurélio, constam as seguintes acepções: “Adj. 2g.: 1. Cível (1). 2. Relativo às relações dos cidadãos entre si, reguladas por normas do Direito Civil. 3. Relativo ao cidadão considerado em suas circunstâncias particulares dentro da sociedade: comportamento civil; direitos e obrigações civis. 4. 'Que não tem caráter militar nem eclesiástico': direito civil; casa civil. 5. Social, civilizado. 6. Cortês, polido: 'Andei com eles [os tropeiros] freqüentemente e achei-os sempre comunicativos e civis.' (Afonso Arinos, Histórias e Paisagens, p.109.) 7. Jur. Diz-se por oposição a criminal: processo civil; tribunal civil. Como substantivo m. 8. 'Indivíduo não militar; paisano'; e 9. Casamento civil”' (destaques nossos).

${ }^{9}$ O livro de Castells (1974) teve importante papel na consolidação dessa área temática de investigações.

${ }^{10}$ Como o caso da Sociedade Nacional de Agricultura, que se origina ainda no século XIX, com uma prática pedagógica e um ativo associacionismo empresarial de grandes proprietários rurais não cafeicultores. Cf. Mendonça (1997).

${ }^{11}$ Ver, especialmente, o estudo de caso sobre a Associação Brasileira para o Desenvolvimento das Indústrias de Base (ABDIB) (Boschi, 1979:181-221).

${ }^{12}$ A Igreja Católica, por seu turno, também já vinha, desde há muito, organizando uma série de entidades, como o círculo Dom Vital, as 'Juventudes' - Operária (JOC), Estudantil (JEC), Universitária (JUC) -, a CNBB e outras associações.

${ }^{13} \mathrm{O}$ trabalho de René Dreifuss, de rara solidez documental e argúcia analítica, vem enfrentando resistências em algumas áreas acadêmicas. Embora nenhuma pesquisa ulterior tenha chegado perto da monumentalidade de seu trabalho documental, há uma certa tendência atual a abandonar pesquisas correlacionando classes sociais, formas de organização social e política e consciência. Ver, a esse respeito, Mattos (2005).

${ }^{14}$ Para o âmbito das associações patronais rurais, cf. Mendonça (2005).

${ }^{15}$ Como a influência de Alain Touraine na sociologia brasileira em, por exemplo, SchererWarren \& Krischke (1987).

${ }^{16}$ Caberia a Ruth Cardoso explicitar essa limitação nos estudos (e nas práticas que sustentavam), ainda que com excessiva ênfase na institucionalidade formal (Cardoso, 1987). 
${ }^{17}$ Essa é a base do argumento do livro do sociólogo francês D. Pécaut (1990, passim), que se derrama em elogios aos intelectuais brasileiros por terem, enfim, chegado às tais 'estratégias de racionalidade limitada' que seriam, para ele, sinônimos de democracia.

${ }^{18}$ Ver a análise - então fascinada por esse processo - realizada por Durham (1984). Já então, Eunice Durham criticava acidamente os pesquisadores que procuravam um elo entre movimentos sociais e classes, acusando-os de tentar impor suas expectativas aos objetos de sua pesquisa.

${ }^{19}$ Gramsci, extremamente atento aos movimentos da consciência social, considera que, após o momento econômico-corporativo (base organizativa mais elementar), pode-se chegar a um segundo momento: "aquele em que se atinge a consciência da solidariedade de interesses entre todos os membros do grupo social, mas ainda no campo meramente econômico. Já se põe neste momento a questão do Estado, mas apenas no terreno da obtenção de uma igualdade político-jurídica com os grupos dominantes, já que se reivindica o direito de participar da legislação e da administração e mesmo de modificá-las, de reformá-las, mas nos quadros fundamentais existentes" (Gramsci, 2000:41). A este, estamos denominando 'momento estatal', uma vez que já se exprime como demanda de igualdade genérica, mas não significa uma contraposição universal mais ampla.

${ }^{20}$ Criada em 1980, intensificou suas atividades no momento da Constituinte, tendo como figura central Antonio Delfim Netto. Era mantida por cinqüenta empresas e associações, nacionais e internacionais. Seu presidente, Renato Ticoulat Filho (ex-presidente da Sociedade Rural Brasileira), a definia como limitada a "atividades acadêmicas", de um "apoliticismo absoluto", embora tivesse como objetivo, ainda em suas palavras, "unir o empresariado no sentido de demonstrar que o neoliberalismo não é um capitalismo selvagem, um criador de miséria, mas uma alavanca de desenvolvimento social...". Folha de S.Paulo, 05.10.1986, apud Dreifuss (1989:52-53), destaques nossos.

${ }^{21}$ Essa entidade, criada em 1986, deveria operar como a contrapartida empresarial da CUT. Chegou-se a cogitar em chamá-la de Central Única dos Empresários (CUE)... (Dreifuss, 1989).

${ }^{22}$ Cf. Dreifuss (1989, passim). Nesse livro, Dreifuss rastreou, por meio de informações veiculadas na imprensa, enorme quantidade de associações empresariais, suas disputas internas, montantes de recursos gastos, assim como a facilidade, pela quantidade de recursos, para estabelecer agências em diversos estados, centralizando suas sedes em Brasília.

${ }^{23}$ Para se ter uma idéia, seguem alguns dos membros do Conselho Estadual Provisório do MCRN em São Paulo: Herbert Levy, Pedro Conde (Banco de Crédito Nacional), Mario Amato (Grupo Springer, presidente da Fiesp, membro da Federação de Comércio de São Paulo, dirigente do Fórum Informal, Instituto Liberal); José Ermírio de Morais Filho (Grupo Votorantim e ex-dirigente do Ipes); Lázaro de Mello Brandão (Bradesco); Flávio Teles de Menezes (Sociedade Rural Brasileira, Cedes, Fórum Informal); Rubem Ludwig (general, ex-ministro da Educação do governo Figueiredo, diretor da Eriksson); Iapery T. 
Brito Guerra (almirante); Paulo Villares (Aços Villares, ex-dirigente do Ipes); Jorge Gerdau Joahnnpeter (Metalúrgica Gerdau, Siderúrgica Riograndense S.A., Siderúrgica Aço Norte, Cosigua, Cedes, Instituto Liberal); José Mindlin (Metal Leve, Instituto Liberal), Victor Civita (Grupo Abril), dentre outros. Cf. Dreifuss (1989).

${ }^{24}$ Cf. Mattos (1998) em especial para algumas importantes modalidades de greves não corporativas, como o caso dos metroviários do Rio de Janeiro.

${ }^{25}$ Folha de S.Paulo, 20/08/1987, apud Giannotti (2002).

26 'Sustentar a 'qualidade' contra a quantidade significa, precisamente, apenas isto: manter intactas determinadas condições de vida social nas quais alguns são pura quantidade, outros qualidade. E como é agradável considerar-se representantes patenteados da qualidade, da beleza, do pensamento, etc.! Não existe madame do 'grande mundo' que não acredite cumprir esta função de conservar sobre a terra a qualidade e a beleza!' (Gramsci, 2001:409, v.1).

${ }^{27}$ O empresário Afif Domingues, que aceitava a liberalização sindical, diria a esse respeito: "Estou sendo vítima de uma aliança entre o peleguismo patronal e o peleguismo dos trabalhadores” (Dreifuss, 1989:229-230).

\section{REFERÊNCIAS BIBLIOGRÁFICAS}

ALMEIDA, G. R. História de uma Década Quase Perdida (1979-1989), 2000. Tese de Doutorado, Niterói: Departamento de História, Universidade Federal Fluminense. (Mimeo.)

ALVES, M. H. N. Estado e Oposição no Brasil (1964-1984). 4.ed. Petrópolis: Vozes, 1987.

ANDERSON, P. As Antinomias de Gramsci: crítica marxista. São Paulo: Joruês, 1986.

ASSUNÇÃO, L. L. A invenção das ONGs: do serviço invisível à profissão sem nome, 1993. Tese de Doutorado, Rio de Janeiro: Museu Nacional, UFRJ.

BOBBIO, N. Estado, Governo, Sociedade: para uma teoria geral da política. 4.ed. Rio de Janeiro: Paz e Terra, 1992.

BOITO JR., A. Política Neoliberal e Sindicalismo no Brasil. São Paulo: Xamã, 1999.

BOSCHI, R. R. Elites Industriais e Democracia. Rio de Janeiro: Graal, 1979.

CARDOSO, R. Movimentos sociais na América Latina. Revista Brasileira de Ciências Sociais, 1(3):27-37, 1987.

CASTELLS, M. La Cuestión Urbana. México: Siglo XXI, 1974 (edição original de 1972).

COUTINHO, C. N. Marxismo e Política. São Paulo: Cortez, 1994.

COUTINHO, C. N. Gramsci: um estudo sobre seu pensamento político. Nova edição ampliada. Rio de Janeiro: Civilização Brasileira, 1999. 
DINIZ, E. Empresário, Estado e Capitalismo no Brasil: 1930-45. Rio de Janeiro: Paz e Terra, 1978.

DREIFUSS, R. A. A Internacional Capitalista: estratégias e táticas do empresariado transnacional, 1918-1986. Rio de Janeiro: Espaço e Tempo, 1986.

DREIFUSS, R. A. 1964: a conquista do Estado - ação política, poder e golpe de classe. 5.ed. Petrópolis: Vozes, 1987.

DREIFUSS, R. A. O Jogo da Direita. Petrópolis: Vozes, 1989.

DURHAM, E. R. Movimentos sociais: a construção da cidadania. Novos Estudos Cebrap, 10, out. 1984.

FERNANDES, R. C. \& LANDIM, L. Um perfil das ONGs no Brasil. Comunicações do Iser, 22:44-56, ano 5, nov. 1986.

FONTES, V. Reflexões Im-Pertinentes. Rio de Janeiro: Bom Texto, 2005.

FREITAS, E. S. A Firjan Ontem e Hoje: a representação industrial do Rio de Janeiro (1827-1995), 2000. Mestrado em Planejamento Urbano e Regional, Rio de Janeiro: IPPUR/UFRJ.

GIANNOTTI, V. Forşa Sindical: a central neoliberal, de Medeiros a Paulinho. Rio de Janeiro: Mauad, 2002.

GRAMSCI, A. Cadernos do Cárcere: Maquiavel - notas sobre o Estado e a política. v.3. Rio de Janeiro: Civilização Brasileira, 2000.

GRAMSCI, A. Cadernos do Cárcere: os intelectuais; o princípio educativo; jornalismo. v.1 e 2. 2.ed. Rio de Janeiro: Civilização Brasileira, 2001.

GRAMSCI, A. Cartas do Cárcere. 2v. Rio de Janeiro: Civilização Brasileira, 2005.

HYPPOLYTE, J. Introducão à Filosofia da História de Hegel. Rio de Janeiro: Civilização Brasileira, 1971.

HIRSCHMAN, A. O. As Paixões e os Interesses: argumentos politicos para o capitalismo antes de seu triunfo. Rio de Janeiro: Paz e Terra, 1979.

LEOPOLDI, M. A. Política e Interesses na Industrialização Brasileira. Rio de Janeiro: Paz e Terra, 2000.

LIGUORI, G. Estado e sociedade civil: entender Gramsci para entender a realidade. In: COUTINHO, C. N. \& TEIXEIRA, A. P. Ler Gramsci, Entender a Realidade. Rio de Janeiro: Civilização Brasileira, 2003. p.173-188.

LOSURDO, D. Hegel, Marx e a Tradição Liberal: liberdade, igualdade, estado. São Paulo: Unesp, 1998.

MACPHERSON, C. B. Théorie Politique de l'Individualisme Possessif: de Hobbes à Locke. Paris: Gallimard, 2004.

MANENT, P. História Intelectual do Liberalismo: dez lições. Rio de Janeiro: Imago, 1990. 
MARX, K. \& ENGELS, F. La Ideologia Alemana. 5.ed. Montevidéu: Pueblos Unidos; Barcelona: Grijalbo, 1974.

MATTOS, M. B. Novos e Velhos Sindicalismos. Niterói: Vício de Leitura, 1998.

MATTOS, M. B. Os trabalhadores e o golpe de 1964: um balanço da historiografia. História \& Luta de Classes, 1, abr. 2005.

MENDEZ, A. G. B. O Ministério dos Industriais: a Federação das Indústrias do estado de São Paulo na crise das décadas de 1980 e 1990, 2004. Tese de Doutorado, Campinas: Departamento de Ciência Política, Unicamp.

MENDONÇA, S. O Ruralismo Brasileiro. São Paulo: Hucitec, 1997.

MENDONÇA, S. R. Estado e representação patronal na agricultura brasileira: o caso SNA. Relatório final de pesquisa ao CNPq. Niterói, 2005. (Mimeo.)

NOGUEIRA, A. J. F. M. Relações de trabalho e sindicalismo entre o público e o privado no Brasil. In: XXIX ENCONTRO ANUAL DA ANPOCS. GT 26: Trabalho e Sindicato na Sociedade Contemporânea, 2005.

NORONHA, E. G. A explosão das greves na década de 80. In: BOITO JR., A. (Org.). O Sindicalismo Brasileiro nos Anos 80. Rio de Janeiro: Paz e Terra, 1991.

PÉCAUT, D. Os Intelectuais e a Política no Brasil. São Paulo: Ática, 1990.

POUlANTZAS, N. O Estado, o Poder, o Socialismo. São Paulo: Paz e Terra, 2000.

SCHERER-WARREN, I. \& KRISCHKE, P. J. (Orgs.). Uma Revolução no Cotidiano? Os novos movimentos sociais na América do Sul. São Paulo: Brasiliense, 1987.

VIANNA, L. W. Liberalismo e Sindicato no Brasil. 4.ed. Belo Horizonte: Ed. UFMG, 1999. 


\title{
7. Fundamentos Científicos e Técnicos da Relação Trabalho e Educação no Brasil DE HOJE
}

\author{
Gaudêncio Frigotto
}

\begin{abstract}
A educação tem duas funções principais numa sociedade capitalista: a produção das qualificações necessárias ao funcionamento da economia, e a formação de quadros e a elaboração de métodos para um controle politico.

Mészáros, in Marx e a Teoria da Alimentação, 1981.
\end{abstract}

\begin{abstract}
A epígrafe nos indica, de imediato, que as relações sociais capitalistas constituem um bloco histórico dentro do qual se articulam dimensões da estrutura econômico-social ${ }^{1}$ e da superestrutura ideológica e política. Isso significa que, dentro de uma compreensão dialética da realidade histórica, as dimensões econômicas, científicas, técnicas e políticas da educação se constroem de forma articulada por diferentes mediações e, por se darem numa sociedade de classes, se produzem dentro de contradições, conflitos, antagonismos e disputas. Por esse motivo, embora a educação e a escola, na sociedade capitalista moderna, tendam ao seu papel de reprodução das relações sociais dominantes, mediante - como nos expõe Gramsci - a formação de intelectuais de diferentes tipos, não se reduzem a ela. A educação em geral que se dá nas relações sociais e os processos educativos e de conhecimentos específicos que se produzem na escola e nos processos de qualificação técnica e tecnológica interessam à classe trabalhadora e a seu projeto histórico de superação do modo de produção capitalista.

Sabemos que a natureza estrutural das relações sociais do sistema capital é a mesma em qualquer parte do mundo, tendo a propriedade privada dos
\end{abstract}


meios e instrumentos de produção pelos capitalistas e, como decorrência, a extração da mais-valia (absoluta e relativa) como elementos centrais. Todavia, pelas contradições internas e pela luta intra e entre classes e frações de classes, o capitalismo assume particularidades e configurações diversas e desiguais em formações histórico-sociais específicas. Assim, a desigualdade entre os hemisférios Norte e Sul ou entre países do capitalismo central e do capitalismo dependente periférico são expressões das relações de força intercapitalistas e das lutas anticapitalistas. Aqui buscamos, num primeiro item, discutir alguns aspectos dos fundamentos da compreensão da categoria trabalho e das bases científico-técnicas da produção no modo de produção capitalista em geral. O pressuposto básico é de que o trabalho é a categoria 'ontocriativa' da vida humana, e o conhecimento, a ciência, a técnica e a tecnologia e a própria cultura são mediações produzidas pelo trabalho na relação entre os seres humanos e os meios de vida. ${ }^{2}$ Assim, o desenvolvimento científico-técnico dos instrumentos de produção é que distingue as épocas econômico-sociais e não o que se produz. Sob o capitalismo, o trabalho se transforma dominantemente em trabalho alienado, mas não se reduz a ele. A ciência, a técnica e a tecnologia, como produções humanas e práticas sociais, não são neutras e se constituem em forças de dominação e alienação, mas também podem se constituir em elementos da emancipação humana e são cruciais e necessários a ela.

Num segundo item vamos configurar, brevemente, a especificidade do capitalismo que foi sendo configurado no Brasil e como ele se apresenta atualmente. Essa configuração nos permite apreender qual o papel reservado ao Brasil na divisão internacional do trabalho e como se efetivam, nesse contexto, a formação do trabalho simples e complexo e os desafios e dilemas que enfrentamos. As concepções, os projetos e as políticas de educação escolar e de educação profissional em disputa hoje, no Brasil, ganham sentido como constituídos e constituintes da especificidade de projeto de sociedade em disputa pelo capital e pela classe trabalhadora.

Como último item, nos interessa analisar quais as dificuldades objetivas e subjetivas da afirmação da concepção e da prática da educação escolar omnilateral e politécnica, assim como as de processos massivos de qualificação científicotécnica do trabalhador que superem a lógica do adestramento.

$\mathrm{Na}$ parte final, destacaremos alguns pontos e desafios para as forças sociais de esquerda socialista na luta contra-hegemônica por um projeto de desenvolvimento nacional popular e democrático de massa no Brasil, articulado 
a um projeto de educação escolar e qualificação científico-técnica dos trabalhadores - um projeto que estabeleça a relação orgânica entre a formação intelectual e a produção material, a teoria e a prática no desenvolvimento dos fundamentos científicos, filosóficos e culturais de todos os processos produtivos e de sua atuação na sociedade como sujeitos emancipados. Trata-se, enfim, de construir as condições objetivas e subjetivas de um projeto societário de 'novo tipo'.

\section{Ciência, Técnica e Tecnologia como forças de Dominação sob o Capital e Necessidade para a Emancipação da Classe Trabalhadora}

Explicita-se, de forma cada vez mais intensa, que a ciência, a técnica e a tecnologia constituem-se, por excelência, no núcleo fundamental do desenvolvimento das forças produtivas e, portanto, em mediação crucial na possibilidade de diminuição do trabalho regulado pelo 'mundo da necessidade' e pela ampliação do trabalho livre, dilatador da emancipação e da criatividade humanas. Dois aspectos interligados, porém igualmente equivocados, têm sido dominantes na visão da ciência e da técnica na sociedade atual. O primeiro é o do fetiche e do determinismo da ciência, da técnica e da tecnologia tomadas como forças autônomas das relações sociais de produção, de poder e de classe. A forma mais apologética desse fetiche aparece, atualmente, sob as noções de 'sociedade pós-industrial e sociedade do conhecimento', que expressam a tese de que a ciência, a técnica e as novas tecnologias nos conduziram ao fim do proletariado, à emergência do 'cognitariado' e, conseqüentemente, à superação da sociedade de classes, sem acabar com o sistema capital - pelo contrário, tornando-o um sistema eterno.

Como sinaliza Carlos Paris, "a manipulação ideológica do avanço tecnológico pretende apresentar-nos a imagem de um mundo em que os grandes problemas estão resolvidos, e, para gozar a vida, o cidadão só precisa apertar diversos botões ou manejar objetos de apoio" (Paris, 2002:175). Mas, como prossegue este autor, na verdade se trata de uma "epiderme embelezada" que encobre uma imensa maioria de seres humanos que sequer conseguem satisfazer às suas necessidades primárias.

Para sociedades como a brasileira, essa é uma realidade candente e muito concreta. Trata-se de uma sociedade, como veremos, que alcançou um significativo desenvolvimento industrial que permite aos setores de ponta produzir 
superávit primário sem precedentes, liderado pelas exportações do agronegócio. Ao mesmo tempo e paradoxalmente, o programa social básico do atual governo é o Fome Zero, cujo escopo é dar três refeições por dia para aproximadamente cinqüenta milhões de brasileiros. Mas essas contradições atingem também o núcleo do capitalismo central. A revolta, iniciada em novembro de 2005, dos jovens pobres dos bairros habitados por imigrantes de várias nacionalidades, na mais republicana das sociedades ocidentais, a França, é uma outra face das contradições insanáveis do capitalismo hoje realmente existente.

O outro viés situa-se na visão de 'pura negatividade' da ciência, da técnica e da tecnologia em face da sua subordinação aos processos de exploração e alienação do trabalhador como força cada vez mais diretamente produtiva do metabolismo e da reprodução ampliada do capital. Isso conduz a uma armadilha para aqueles que lutam pela superação do sistema capital de relações sociais, por encaminhar o embate para um âmbito exclusivamente ideológico e/ou por conduzir à tese de que a travessia para o socialismo se efetiva pela degradação e pela miséria social - 'tese do quanto pior melhor' - e não pelo aprofundamento das contradições entre o exponencial avanço das forças produtivas e o caráter cada vez mais opaco e anti-social das relações sociais sob o sistema capital.

Os dois vieses decorrem de uma análise que oculta o fato de que a atividade humana que produz o conhecimento e o desenvolvimento da técnica e da tecnologia, assim como seus vínculos imediatos ou mediatos com os processos produtivos, se define como/e assume o sentido de alienação e exploração ou de emancipação no âmbito das relações sociais determinadas historicamente. Ou seja, a forma histórica dominante da ciência, da técnica e da tecnologia que se constituíram como forças produtivas destrutivas, expropriadoras e alienadoras do trabalho e do trabalhador, sob o sistema capital, não é determinação a elas intrínseca, mas depende de como elas são dominantemente decididas, produzidas e apropriadas social e historicamente sob esse sistema.

Essa compreensão nos conduz, então, ao fato de que a ciência, a técnica e a tecnologia são alvo de uma disputa de projetos sociais antagônicos da existência humana. A superação do capitalismo somente pode ser atingida pela luta de classes, partindo da identificação e da exploração, no plano histórico, de suas insanáveis e cada vez mais profundas contradições. Os conhecimentos científico, técnico e tecnológico são partes cruciais dessa disputa hegemônica e condição sine qua non da sociedade socialista. O que lhes dá caráter destrutivo, expropriador e alienador ou de emancipação humana é o projeto societário ao 
qual se vinculam e dentro do qual se desenvolvem. O papel que cumpre o desenvolvimento científico, técnico, tecnológico e filosófico na afirmação e na possibilidade da continuidade da revolução socialista em Cuba - mesmo com um bloqueio econômico e violência militar e ideológica de mais de meio século das forças imperialistas lideradas pelos Estados Unidos - elucida o que queremos realçar.

Não é, tampouco, da natureza do avanço científico-técnico e tecnológico desempregar, mas incorporar como trabalho morto, força produtiva unilateral do capital. O exemplo de Cuba, uma vez mais, mostra que o intenso avanço científico-técnico e tecnológico não é incompatível, mesmo numa sociedade pobre, com uma política de pleno emprego. A ciência, a técnica e a tecnologia libertas do sistema de classes sociais podem diminuir o trabalho necessário e liberar efetivamente tempo livre.

A compreensão do que dissemos inscreve-se na tradição da análise do processo histórico real de Marx e Engels, que reconhecem o papel revolucionário do projeto da burguesia tanto em relação às visões metafísicas da realidade histórica quanto às concepções contemplativas da filosofia idealista e de valorização unidimensional do trabalho intelectual e do desprezo pelo trabalho produtivo vinculado à produção material do ser humano. O que define a negatividade do projeto da burguesia, centro da crítica de Marx e Engels, é que ele se estrutura dentro da 'pré-história do gênero humano', como uma sociedade de classes. ${ }^{4}$ Esses autores criticam os fundamentos do socialismo utópico por seu descolamento do processo histórico real, no qual a ciência, a técnica e a tecnologia desempenham um papel cada vez mais crucial. $^{5}$

Dos pensadores que desenvolveram o legado teórico de Marx ao longo do século XX, daremos especial ênfase às formulações de Gramsci em relação ao papel central da ciência e da técnica no processo histórico atual, por serem as suas formulações, como apontam autores brasileiros como Carlos Nelson Coutinho e Lúcia Neves, fundamentais para entendermos a natureza específica da sociedade de classe que se configura hoje no Brasil. Sob esse ponto de vista citaremos autores contemporâneos, nacionais e do exterior, que nos ajudam a entender o capitalismo hoje, suas crises e a possibilidade de explorá-las, mormente sobre o tema de que nos ocuparemos aqui.

Delineados esses pressupostos, nos ocuparemos agora de duas ordens de questões que, embora aparentemente distantes do objeto específico deste 
artigo, são fundamentos imprescindíveis: o trabalho na sua dimensão de atividade vital ou práxis criativa do ser humano e a forma histórica do trabalho alienado sob o capitalismo; e o conhecimento científico e a técnica como respostas às necessidades humanas e como criadores de possibilidades de ampliação e extensão de sentidos humanos - o socialismo como sociedade tecnológica, e a ciência, a técnica e a tecnologia como forças do capital e 'nova esfinge' que ameaçam a humanidade.

\section{O tRABALHO COMO ATIVIDAdE VITAL E COMO ALIENAÇÃO}

\section{SOB O CAPITALISMO}

As distinções entre o trabalho na sua dimensão ontocriativa e a forma alienada - que ele assume nas sociedades estruturadas pelo antagonismo de classes - e entre a necessária divisão social do trabalho e a divisão técnica - que ele assume sob as relações capitalistas de produção - são fundamentos cruciais e elementares para não se incorrer tanto nas teses do fim do trabalho quanto no determinismo tecnológico do fim das classes sociais ou da negatividade absoluta da técnica e da tecnologia já aludidos.

Nos Manuscritos Econômicos e Filosóficos, Marx (1972) delineia o eixo central da dimensão ontocriativa do trabalho ao mostrar que, enquanto o animal não se distingue de sua atividade vital, nasce regulado e programado por sua natureza - por isso não a projeta teleologicamente e não a modifica, mas se adapta e responde instintivamente ao meio -, os seres humanos, embora seres da natureza, criam e recriam, pela ação consciente do trabalho, a sua própria existência. Em O Capital, Marx retoma e aprofunda a dimensão ontocriativa do trabalho humano, evidenciando que ele é uma resposta às necessidades vitais, historicamente determinadas, e ao mesmo tempo um processo aberto que cria novas condições que modificam a sua própria natureza (Marx, 1983).

Lukács, partindo dessa concepção de Marx, desenvolve extensa obra sobre a ontologia do ser social. Em sua análise, mostra que é pela atividade consciente do trabalho que o ser humano se transcende como ser da natureza orgânica e se constitui ser social, dando respostas às suas necessidades vitais. "Com justa razão se pode designar o homem que trabalha, ou seja, o animal tornado homem através do trabalho, como um ser que dá respostas. Com efeito, é inegável que toda a atividade laborativa surge como solução de respostas ao carecimento que a provoca" (Lukács, 1978:5). 
Sob esse ponto de vista, o trabalho 'é um processo que permeia todo o ser do homem e constitui a sua especificidade'. Por isso não se reduz à "atividade laborativa ou emprego" (Kosik, 1986), mas à produção de todas as dimensões da vida humana. $\mathrm{Na}$ sua dimensão mais crucial, ele aparece como atividade que responde à produção dos elementos necessários e imperativos à vida biológica dos seres humanos como seres ou animais evoluídos da natureza. Concomitantemente, porém, responde às necessidades de sua vida cultural, social, estética, simbólica, lúdica e afetiva. Trata-se de necessidades que, por serem históricas, assumem especificidades no tempo e no espaço.

Nessa concepção, o trabalho engendra um princípio formativo ou educativo. Esse princípio educativo deriva do fato de que todos os seres humanos são seres da natureza e, portanto, têm a necessidade de se alimentar, de se proteger das intempéries e criar seus meios de vida. É fundamental socializar, desde a infância, o princípio de que a tarefa de prover a subsistência e outras esferas da vida pelo trabalho é comum a todos os seres humanos, evitando-se, dessa forma, criar indivíduos ou grupos que exploram e vivem do trabalho de outros e se constituem, na expressão de Gramsci, em "mamíferos de luxo". O trabalho como princípio educativo, então, não é em Marx e Gramsci uma técnica didática ou metodológica no processo de aprendizagem, mas um pressuposto ontológico e ético-político no processo de socialização humana. ${ }^{6}$

A história do trabalho humano, todavia, efetivou-se até o presente, como mostra Marx, sob a cisão do gênero humano em classes sociais - do tripalium das sociedades escravocratas até a atual forma de trabalho alienado sob o capitalismo. Embora a revolução capitalista engendre, como assinalamos, um caráter 'civilizatório' em relação aos modos de produção pré-capitalistas, trata-se de um avanço restrito e relativo, pois mantém a divisão dos seres humanos em classes sociais antagônicas: aqueles que detêm a propriedade privada do capital (propriedade de meios e instrumentos de produção com o fim de gerar lucro) e aqueles que, para se reproduzirem e manterem suas vidas e a de seus filhos, precisam ir ao mercado e vender sua força de trabalho, recebendo em troca uma remuneração ou salário. ${ }^{7}$

Essa relação de classe é a fonte da expropriação do trabalho mediante a apropriação da mais-valia absoluta e relativa ou ambas combinadas (tempo de trabalho não pago) e, portanto, da alienação do trabalhador. Sob o capitalismo, como mostra Mészáros (1981:17), “o homem está alienado da natureza; de si 
mesmo (de sua própria atividade); do seu ser genérico (de seu ser como membro da espécie humana); o homem está alienado do homem (dos outros homens)". Assim, o trabalho, a ciência, a técnica e a tecnologia, sob o capitalismo, deixam de ter centralidade como produtores de valores de uso para os trabalhadores - resposta a necessidades vitais desses seres humanos - e se transformam em meios de produzir alienação e a ampliação do capital dos proprietários privados dos meios e instrumentos de produção.

É nesse contexto que se pode distinguir entre a divisão social do trabalho como a define Marx - "a totalidade de formas heterogêneas de trabalho útil, que diferem em ordem, gênero, espécie e variedade” (apud Bottomore, 2001:112) - e a forma que assume a divisão técnica do trabalho que se dá no processo de produção, na relação entre capital e trabalho.

No primeiro caso, a divisão social do trabalho resulta de processo mediante o qual os seres humanos buscam dar respostas às suas múltiplas necessidades. Nesse processo, como mostra Lukács, o desenvolvimento das respostas às suas carências e necessidades os conduz a gerar perguntas sobre essas carências e suas possibilidades de satisfazer a elas e a buscar patamares superiores de desenvolvimento humano (Lukács, 1978). No segundo caso, a divisão do trabalho se dá entre o capital e o trabalho no seu confronto dentro do processo de produção e se constitui em estratégia do capital para controle do trabalhador e aumento da produtividade do trabalho para ampliação do seu capital.

Como realça Bottomore (2001:112), para Marx

a divisão do trabalho é uma condição necessária para a produção de mercadorias pois, sem atos de trabalho mutuamente independentes, executados isoladamente uns dos outros, não haveria mercadoria para trocar no mercado. Mas a recíproca não é verdadeira: a produção de mercadorias não é uma condição necessária para a existência de uma divisão social do trabalho; mesmo as comunidades primitivas já conheciam a divisão do trabalho, mas nem por isso seus produtos se convertiam em mercadorias. De modo semelhante, a divisão do trabalho dentro de uma fábrica não é o resultado da troca, entre trabalhadores, dos seus produtos individuais.

A superação dessa forma de divisão do trabalho implica o fim da sociedade de classes e, portanto, da sociedade capitalista. Trata-se de estabelecer relações sociais nas quais, como Marx expõe no Manifesto Comunista, 'o livre desenvolvimento de cada um seja a condição do livre desenvolvimento de todos’. 


\section{A CIÊNCIA E A TÉCNICA COMO EXTENSÃO DE SENTIDOS E MEMBROS HUMANOS E COMO FORÇAS DO CAPITAL CONTRA O TRABALHADOR}

A compreensão do trabalho em sua dimensão ontocriativa e a forma que assume o trabalho sob o capitalismo - trabalho alienado - delineiam a função da ciência e de técnica na sociedade. Como vimos, pelo trabalho os seres humanos vão respondendo a necessidades e desafios num processo de desenvolvimento técnico e teleológico cada vez mais complexo. O conhecimento, a técnica e a tecnologia passam a ser desenvolvidos como forma de mediar a força física e mental do ser humano; como tal, quando tomados como criadores de valores de uso para satisfazer às necessidades humanas, constituem-se em verdadeiras extensões dos membros e sentidos do ser humano e fonte de novas necessidades e da viabilidade de sua satisfação.

Essa possibilidade, entretanto, tem sido constrangida por um processo histórico no qual a mediação da ciência, da técnica e da tecnologia na redução do trabalho determinado pela esfera da necessidade, assim como a dilatação do trabalho criativo sob a esfera da liberdade, ${ }^{8}$ tem se dado de forma profundamente limitada e pela não-superação da sociedade cindida em classes sociais portanto, relações desumanizadoras sob o processo de alienação. Não obstante esse limite histórico, dentro do espaço das contradições das sociedades classistas, o homem deixa a condição de ser natural para tornar-se pessoa humana, transforma-se em pessoa humana, transforma-se de espécie animal - que alcançou um certo grau de desenvolvimento relativamente elevado - em gênero humano, humanidade. ${ }^{9}$

Para Lukács, esse processo deriva do desenvolvimento econômico ocorrido até hoje e que explicita três orientações evolutivas:

uma tendência constante no sentido de diminuir o tempo de trabalho socialmente necessário à reprodução dos homens. ( ...) Em segundo lugar esse processo tornou-se cada vez mais nitidamente social. (...) Em terceiro lugar, o desenvolvimento econômico cria ligações quantitativas e qualitativas cada vez mais intensas entre as sociedades singulares originariamente pequenas e autônomas, as quais, no início - de modo objetivo e real - compunham o gênero humano. (Lukács, 1978:12-13)

As orientações evolutivas mencionadas, potenciadas pelo desenvolvimento científico e técnico, poderão efetivamente dilatar os membros e sentidos humanos de forma mais plena apenas quando a humanidade tiver superado qualquer 
caráter coercitivo em sua própria auto-reprodução. Só então terá sido aberto o caminho social da atividade humana como fim autônomo (Lukács, 1978).

O caminho para essa superação e travessia é a construção da sociedade socialista. Esta, para desenvolver-se a afirmar-se como tal e permitir auto-reprodução humana dominantemente na esfera do trabalho livre, tem no avanço da ciência, da técnica e da tecnologia as condições necessárias, ainda que não suficientes. Por isso, para Marx, o socialismo resultaria da consciência de classe dos trabalhadores em relação às contradições entre o avanço das forças produtivas, com base na ciência, na técnica e na tecnologia, e a crescente incapacidade das relações sociais capitalistas de socializar a produção.

Seria possível dizer que o marxismo é a teoria e a prática socialistas de sociedades especificamente tecnológicas. Ou seja, se o trabalho humano que transforma a natureza, tendo em vista objetivos coletivos humanos, é de importância fundamental para a concepção marxista de práxis, a tecnologia é o produto: artefatos que encerram valor e têm valor de uso. Marx ressalta que é a tecnologia, e não a natureza, que tem importância fundamental:

a natureza não fabrica máquinas, locomotivas, ferrovias, telégrafo elétrico, máquina de fiar automática, etc. Tais coisas são produtos da indústria humana; material natural transformado em órgãos da vontade humana que se exerce sobre a natureza, ou da participação humana na natureza. 'São órgãos do cérebro humano, criados pela mão humana' [destaques no original]: o poder do conhecimento objetificado. (Grundrisse, p.706, apud Bottomore, 2001:371)

O fato histórico de que as revoluções socialistas, especialmente a mais impactante, a revolução de 1917 na Rússia, não tenham surgido em sociedades de maior desenvolvimento das forças produtivas não invalida o legado teórico apresentado; apenas mostra que a história não é linear. Pelo contrário, essa teoria pode nos ajudar a entender que tal fato explica, em grande parte, sua derrocada. Essa derrota não significou um fracasso, já que especialmente essa revolução redefiniu política e socialmente o século XX, obrigando a uma regulação da violência do capital. ${ }^{10}$

Tanto Marx quanto os autores marxistas posteriores nos quais apoiamos essa análise evidenciam que a ciência, a técnica e a tecnologia sob o capitalismo têm se potenciado cada vez mais como forças produtivas do capital contra o trabalhador. Assim, o que se materializa é um aprofundamento crescente da 
contradição entre o avanço exponencial das forças produtivas pela incorporação da ciência e da técnica no processo produtivo e as relações sociais que bloqueiam a apropriação desse avanço pelo trabalhador, deslocando-o de modo cada vez mais intenso para a ampliação do capital.

Como observa Marx, a máquina, triunfo do ser humano sobre as forças naturais, converte-se, nas mãos dos capitalistas, em instrumento de servidão de seres humanos a essas mesmas forças: "a máquina, meio infalível para encurtar o trabalho cotidiano, o prolonga, nas mãos do capitalista (...); a máquina, varinha de condão para aumentar a riqueza do produtor, o empobrece, em mãos do capitalista (Marx, apud Paris, 2002:235).

O triunfo assinalado por Marx no século XVIII ganha um desenvolvimento qualitativamente diverso no final do século XX e no início do XXI, permitindo ao capital potenciar sua capacidade de expropriar trabalho e acumular lucros. Por um lado, a 'revolução' digital-molecular, que associa microeletrônica à informática, produz uma mudança qualitativa que altera a matéria, acrescentando à massa e à energia a informação, modificando as bases científicas e técnicas do processo de produção (produção flexível) (Harvey, 1998). Por outro lado, essa mesma tecnologia permite que a tendência do sistema capital de "tomar o globo terrestre", anunciada por Marx e Engels no Manifesto Comunista, se torne um fato real com a mundialização do capital (Chesnais, 1996) e do que Harvey (2005) denomina de novo imperialismo. O desenvolvimento da genética, a descoberta das células-tronco e a clonagem também permitem o controle sobre a vida humana e a produção de membros e órgãos humanos - possibilidades fantásticas de melhoria de prolongamento da vida, mas sob o capitalismo subordinadas à lógica do mercado. Daí esse avanço ser monopólio privado de laboratórios e empresas que mercantilizam órgãos humanos e células.

No plano da ideologia e, portanto, sob a nova pedagogia da hegemonia como estratégia do capital para educar o consenso (Neves, 2005), apresenta-se o desenvolvimento científico, técnico e tecnológico associado à produção e, sob a mundialização do capital, como motor inexorável da nova economia livre, flexível, desregulada. Uma sociedade do conhecimento, pós-classista e 'globalizada'.

O mundo real, porém, é outro. O acesso e a definição política dessas mudanças científico-técnicas e tecnológicas estão dentro de uma lógica sob a dominação do capital, por isso cada vez mais concentradas na mão de poucos 
e uma força produtiva produzida pelo trabalhador que se volta de forma potenciada contra ele. Seguindo essa lógica, a ciência, a técnica e a tecnologia de possibilidade de dilatação da vida se transformam numa monstruosa esfinge que, vorazmente, destrói direitos e ameaça a vida. Essa esfinge não é já a natureza indômita, hostil, revestida de símbolos matriarcais, que assaltava o cidadão Édipo fora dos muros da cidade, mas a própria técnica que se ergue ameaçadora no recinto do mundo que acreditávamos haver forjado para nosso bemestar (Paris, 2002).

Numerosas são as análises que discutem os efeitos econômicos, sociais, culturais, políticos e ideológicos da direção dessas mudanças. A análise mais radical e aguda, por sua abrangência e profundidade, é encontrada em Mészáros (2002) na sua obra magna, Para Além do Capital. Em mais de mil páginas, ele defende a tese central de que o capital esgotou sua capacidade civilizatória. Mészáros contrapõe à tese da destruição criativa de Shumpeter a tese da produção destrutiva. A primeira consiste na dinâmica da competitividade intercapitalista de introduzir incessantemente o avanço científico e técnico no processo produtivo, destruindo os velhos processos técnicos. A segunda se caracteriza, sobretudo, pelo caráter destrutivo. Para manter-se e para prosseguir, o sistema capital funda-se cada vez mais num metabolismo do desperdício, da 'obsolescência planejada', na produção de armas, no desenvolvimento do complexo militar, na destruição da natureza, na produção de 'trabalho supérfluo' - vale dizer: desemprego em massa. Além disso, dentro das políticas de ajuste para recuperar as taxas de lucro, nas últimas décadas o sistema capital vem abolindo quase todos os direitos dos trabalhadores conquistados ao longo do século XX (Mészáros, 2002). ${ }^{11}$

Uma das faces da esfinge que atinge, ainda que de modo diverso em quantidade e nos efeitos, tanto os países do capitalismo central quanto os países de capitalismo dependente e periférico, é o desemprego estrutural, com a criação de um contingente cada vez maior de trabalhadores supérfluos e a precarização e superexploração dos que trabalham. Ganha, assim, extraordinária atualidade histórico-empírica a análise feita por Marx nos Grundrisses (Marx, 1973) e, depois, em O Capital, sobre a contradição entre o fundamento da produção burguesa e seu desenvolvimento.

$\mathrm{Na}$ medida em que a grande indústria se desenvolve, a criação de riqueza efetiva torna-se menos dependente do tempo de trabalho e do quan- 
tum de trabalho utilizado do que do poder dos agentes em movimento durante o tempo de trabalho, poder que, em seu powerful effectiveness (poderosa efetividade), não mantém relação com o tempo de trabalho imediato demandado por sua produção, mas [essa criação] depende muito mais do estado geral da ciência e do processo da tecnologia, ou seja, da utilização desta ciência na produção. (Marx, apud Paiva \& Gianotti, 2000:150-151)

Ao incorporar, de forma crescente, capital morto (ciência e tecnologia) no processo produtivo, o sistema capitalista não libera tempo livre - "redução do trabalho necessário à sociedade a um mínimo” (Paiva \& Gianotti, 2000:151) -, mas trabalho supérfluo sob o desemprego estrutural e o trabalho precário. ${ }^{12}$ Atrofiam-se, assim, a possibilidade do tempo "tornado livre para todos os indivíduos e os meios criados para que possibilitem a educação artística, científica, etc. necessária ao livre desenvolvimento da individualidade" (Paiva \& Gianotti, 2000:157).

Talvez Gramsci (1976) seja o autor marxista que melhor tenha percebido, ao analisar o 'americanismo' e o 'fordismo' na primeira metade do século XX, que as mudanças científicas e técnicas que engendravam alterações qualitativas no conteúdo, na forma e na organização do trabalho urbano-industrial não eram de tipo novo por estarem subordinadas ao metabolismo do capital e se inscreverem na lógica de sua acumulação ampliada e da alienação, mas continham, contraditoriamente, elementos de positividade no processo histórico da luta dos trabalhadores. ${ }^{13}$

As mudanças na base científica, técnica e tecnológica das décadas finais do século XX tampouco são de tipo original. Como expusemos, engendram uma mudança qualitativamente mais profunda no processo produtivo, alterando não apenas o conteúdo, a forma e a organização do trabalho no processo produtivo, mas também a relação entre capital produtivo e capital especulativo e o processo de mundialização do capital, assim como de sua intensa concentração e centralização, tendo em contrapartida a ampliação da miséria humana. Por isso esse novo patamar não é de tipo original, mas também não é pura negatividade.

A análise de Gramsci, por ter se dado a partir das condições históricas objetivas, capta as dimensões contraditórias desse processo. Tais mudanças, ao mesmo tempo que intensificam as formas de exploração e alienação, engendram a possibilidade - como apontamos em Lukács - de patamares superiores 
de desenvolvimento humano. Trata-se de uma contradição em que negatividade e positividade do trabalho humano e da ciência e da técnica se efetivam num mesmo e desigual movimento. Como postula Bensaid, 2000:100, a atitude histórica não é "de negar essa contradição, mas de se instalar nela para trabalhá-la" ${ }^{14}$ A direção é de luta contra-hegemônica para desenvolver relações sociais de tipo original, em que a ciência, a técnica e a tecnologia assumam, também, a marca original, possibilitando ampliar tempo efetivamente livre para que os seres humanos possam desenvolver suas dimensões propriamente humanas.

Uma questão final deste primeiro tópico, a qual apenas enunciaremos, diz respeito à relação de autonomia relativa entre saber científico e saber técnico e tecnológico. Trata-se de uma questão que ganha relevância no Brasil por ter a nova legislação do ensino superior aberto a possibilidade de criação de universidades tecnológicas.

Do que se pode depreender de uma detalhada análise de Carlos Paris (2002), partindo das raízes biológicas da técnica à sua dimensão de realização humana, ela constitui-se num saber e num conhecimento específico, embora não isolado. Essa questão, mostra-nos Paris, já foi posta por Anaxágoras, quando afirmou: "somos inteligentes porque temos mãos"; ou seja, "o Homo faber não só vai dilatando o âmbito e a perfeição de sua técnica, mas iluminando o Homo sapiens" (Paris, 2002:103).

Paris observa, todavia, que na época moderna e contemporânea a tradição intelectual, marcada pela concepção dominante da universidade humboldtiana, mantém uma postura desdenhosa da técnica relegada ao mundo da necessidade e da produção. No mesmo sentido, observa que a classe intelectual se atribui um papel típico da ilustração, o de difusora do saber, esquecendo o papel das classes produtivas no esforço criador de uma nova sociedade (Paris, 2002).

Seguindo o fio condutor traçado por Marx desde os Manuscritos Econômicos e Filosóficos, nos quais indica que "o homem nasce de sua própria atividade vital, objeto de sua vontade e de sua consciência” (Marx, 1972:111), tendo na práxis a categoria da unidade dialética entre ação e pensamento e teoria e atividade prática, a análise de Paris nos conduz a uma síntese na qual os saberes técnico, tecnológico ${ }^{15}$ e científico, em suas especificidades, relacionam-se e fecundam-se dialeticamente. ${ }^{16}$ Desde que o ser humano se faz, pelo trabalho, humano-social, fabrica objetos, e estes inspiram o processo de construção do conhecimento. Desse modo, 
os instrumentos adquirem uma nova função a serviço não da ação, mas do conhecimento, da dilatação do âmbito de nossos sentidos e de uma maior precisão da observação; (...) o conhecimento fundamenta as possibilidades da técnica e esta, por sua vez, leva ao conhecimento humano conceitos, experiências e materiais, como os aparatos científicos que contribuem para o desenvolvimento do saber. (Paris, 2002:221-222).

Nessa perspectiva, não parece plausível, sem cair no reducionismo tecnicista ou no cientificismo abstrato, separar a técnica, a tecnologia e a ciência. Trata-se de uma unidade do diverso. A ênfase numa das dimensões pode configurar formas institucionais diversas, mas isso não permite separar arbitrária e mecanicamente o que a realidade humana une dialeticamente. $\mathrm{Na}$ base dessa separação, que o capital gerencia, situa-se a divisão técnica do trabalho que limita ou impede o trabalhador no sentido de compreender a unidade dessas dimensões do trabalho humano.

\section{O Brasil na Divisão Internacional do Trabalho e na Relação Trabalho Simples e Complexo}

Em 15 de novembro de 2005, o Brasil registrou 116 anos de república, preservando, todavia, profundas marcas do longo período de colônia e do sistema escravocrata, ao mesmo tempo que apresenta traços de uma sociedade industrial moderna. Essa herança colonizada e escravocrata reitera-se e atualizase sob novas formas de dominação e colonização. ${ }^{17} \mathrm{O}$ bloco histórico que resulta desse processo societário específico define o tipo de sociedade que constituímos no plano da estrutura econômico-social, na superestrutura política interna e na relação externa - e como decorrência disso, qual o patamar científico e técnico que atingimos, qual a posição em que nos situamos na divisão internacional do trabalho e quais suas interfaces com as demandas do trabalho simples e complexo. Por último, neste segundo item, sinalizaremos brevemente a luta contra-hegemônica da classe trabalhadora, a dificuldade e a necessidade de um projeto de educação escolar e de formação técnico-profissional centrado na concepção da politecnia ou da educação tecnológica. Na conclusão, destacaremos os desafios teórico e ético-políticos da esquerda socialista na luta por um projeto de desenvolvimento nacional popular e democrático de massa. 
Brasil do final do SÉculo XX E INÍCIO do SÉculo XI: UM PROCESSO INDUSTRIAL TRUNCADO E UMA SOCIEDADE DESIGUALITÁRIA SEM REMISSÃO ${ }^{18}$

O foco central deste tópico busca realçar a especificidade do bloco histórico que define o capitalismo que veio sendo construído no Brasil (capitalismo dependente) mediado pela natureza do Estado, em sentido estrito e em sentido amplo, como entende Gramsci (2000), e pela natureza da sociedade civil e da democracia, como analisa Coutinho (2000, 2002). A partir dessa compreensão, tenciona-se apreender como se situa o processo educativo escolar na formação científico-técnica dos trabalhadores, procurando responder a um duplo imperativo para a emancipação dessa classe - a apropriação do conhecimento científico, filosófico, cultural, técnico e tecnológico no nível socialmente mais avançado como direito e como necessidade demandada pelas mudanças que se efetivam historicamente nos processos e relações de produção.

Tomamos como horizonte, para um breve balanço da especificidade do capitalismo no Brasil, a indicação de Gramsci que sublinha que, ao se analisar um determinado bloco histórico e as relações de forças sociais em disputa, é crucial distinguir o movimento orgânico ou estrutural, relativamente permanente, dos movimentos conjunturais que ocorrem a partir deste (Gramsci, 2000). Nesse processo articulam-se, de forma indissociável, as determinações da estrutura econômico-social e da superestrutura político-ideológica. ${ }^{19}$ Nesse particular, como enunciamos apoiados em Kosik (1986), torna-se crucial distinguir as mutações estruturais - que mudam o caráter da ordem social - e as mutações derivadas, secundárias, que modificam a ordem social sem, porém, mudar essencialmente seu caráter.

Ao olhar para formação do tipo de bloco histórico que se constituiu no Brasil, podemos observar mudanças significativas, mormente após 1930, quando se criam condições para a constituição de uma sociedade urbano-industrial. Esse processo se acelerou da década de 1950 para cá. No plano estrutural há, porém, na sociedade brasileira, um tecido profundamente opaco nas relações de poder e de propriedade que se move conjunturalmente, mas que no seu núcleo fundamental reitera um eterno castigo de Sísifo. ${ }^{20}$

Reproduz-se, desse modo, uma das sociedades ocidentais em que a violência de classe a constitui nas mais desiguais do mundo mediante os processos políticos que Gramsci denominou de revolução passiva e de transformismo. 
Trata-se de mudanças (rearranjo das frações e dos interesses da classe dominante) nos âmbitos político, econômico, social, cultural e educacional, cujo resultado é a manutenção das estruturas de poder e privilégio: manutenção do latifúndio ou da extrema concentração da propriedade da terra; concentração extrema da riqueza e da renda; isenção de impostos para grandes fortunas; grupos econômicos poderosos e sistema financeiro predatório; e uma tributação fiscal regressiva. ${ }^{21}$

O processo de desenvolvimento de um capitalismo dependente ${ }^{22}$ e cada vez mais associado aos centros hegemônicos do capital articula elementos culturais, políticos e econômicos que determinam que os avanços materializados no aumento do Produto Interno Bruto (PIB), na produtividade da economia, não só mantenham mas ampliem a concentração de capital e de renda e, portanto, a desigualdade entre as classes e frações de classe. No que nos permite o espaço deste texto, sinalizamos brevemente análises que nos ajudam a ver como se articulam esses elementos e como eles determinam nosso tipo de inserção na divisão internacional do trabalho e a fragilidade da educação escolar e da formação técnico-profissional da força de trabalho.

No plano cultural, somos herdeiros da mentalidade da "dialética da colonização" (Bosi, 1992) e do estigma escravocrata que perfila uma classe dominante, "vanguarda do atraso e atraso da vanguarda" (Oliveira, 1998), profundamente elitista e violenta. Uma mentalidade que alia a violência do coronel das velhas oligarquias à visão preconceituosa do bacharel; do desprezo ao trabalho manual e técnico e ao esforço de produzirmos ciência, técnica e tecnologia.

No plano político, essa cultura se explicita por uma democracia ou processo de democratização restrito ${ }^{23}$ e pela hipertrofia do poder estatal e do Poder Executivo (de cunho paternalista ou populista), pelo clientelismo e nepotismo, pela corrupção e por ditaduras e golpes. Coutinho (2002) nos mostra que, paradoxalmente, o Brasil saiu da ditadura civil-militar de 1964 com uma sociedade civil, em termos gramscianos, de tipo ocidental. Trata-se de um equilíbrio maior entre o Estado em sentido estrito e a sociedade civil. Entretanto, a regressão social imposta pelo neoliberalismo na década de 1990 operou uma reversão para uma sociedade ocidental de tipo americano, resultando daí uma democracia de natureza restrita e fraca (Coutinho, 2000). Este autor observa que o contexto da ditadura induziu a uma leitura equivocada da 'sociedade civil': "tudo o que vem do Estado é ruim, tudo o que vem da sociedade civil é bom” (Coutinho, 2002:33). 
Como mostram Neves (2005) e Rodrigues (1998), os aparelhos de hegemonia da burguesia brasileira foram construindo, de forma sistemática, um ideário ou pedagogia da hegemonia em torno do pensamento empresarial, antes e depois da ditadura. A partir da década de 1990, o ideário situa-se em torno da ideologia neoliberal da globalização, da necessidade do ajuste mediante a reforma do Estado, da reestruturação produtiva, da desregulamentação, da flexibilização e da privatização.

A anatomia do tecido estrutural do capitalismo que se afirma e reitera no Brasil, de forma mais radical, no final do século XX e no início do século XXI nos é feita por quatro intelectuais do pensamento crítico social, político, cultural e econômico: Caio Prado Júnior, Celso Furtado, Florestan Fernandes e Francisco de Oliveira.

Para Caio Prado Júnior (1966), três problemas convivem e se reforçam na nossa formação social desigual, impedindo mudanças estruturais. O primeiro é o mimetismo na análise de nossa realidade histórica, que se caracteriza por uma colonização intelectual, que hoje se dá pela subserviência ao pensamento único dos organismos internacionais e de seus intelectuais e técnicos. Os protagonistas do projeto econômico e das propostas de reformas educacionais a partir da década de 1990 no Brasil se formaram em universidades estrangeiras ícones do pensamento desses organismos e/ou trabalharam neles. No âmbito educacional, que nos interessa mais de perto, o ex-ministro Paulo Renato Souza, Cláudio de Moura Castro, João Batista de Araújo e Guiomar Nambu de Mello, entre outros, são exemplos emblemáticos. O segundo problema é o crescente endividamento externo e a forma de solucioná-lo. O último constitui-se pela abismal assimetria entre o poder do capital e o do trabalho. O salário mínimo, relacionado ao PIB e à precária proteção social e de direitos do trabalhador, é indicação dessa assimetria. ${ }^{24}$

Florestan Fernandes e Francisco de Oliveira, seguindo a herança do pensamento dialético de Marx, invertem o modo de pensar liberal e de boa parte da esquerda centrados na tese da antinomia de uma sociedade cindida entre o tradicional, o atrasado, o subdesenvolvido, e o moderno e desenvolvido, sendo as características primeiras impeditivas do avanço das segundas. Pelo contrário, como nos mostram esses autores, essas características definem a forma específica de nosso capitalismo dependente e subordinado.

No âmbito da constituição da classe detentora do capital ou da burguesia brasileira, a análise de Fernandes $(1975,1981)$ não compartilha da tese de que 
a 'revolução burguesa' foi abortada pela natureza de dualidade da nossa formação social (Brasil arcaico, marcado pelo atraso e responsável pelo ritmo lento do desenvolvimento do Brasil moderno). Para Fernandes, ao contrário, o que vai ocorrer no plano estrutural é que as crises conjunturais entre as frações da classe dominante acabam sendo superadas mediante processos de rearticulação do poder da classe burguesa numa estratégia de conciliação de interesses entre o denominado arcaico e o moderno. Na chamada Revolução Constitucional de 1932, o governo Vargas recompõe as frações da classe burguesa rearticulando os interesses em disputa em que antigas e novas formas de dominação se potenciam em nome do poder de classe. Trata-se, para Fernandes, de um processo que reitera, ao longo de nossa história, a "modernização do arcaico" e não a ruptura de estruturas de profunda desigualdade econômica, social, cultual e educacional.

De forma mais ampla e, também, no que nos interessa de específico, Francisco de Oliveira nos permite fechar esta breve síntese das determinações estruturais que nos trouxeram até hoje. Para ele, a imbricação do atraso, do tradicional e do arcaico com o moderno e o desenvolvido potencializa nossa forma específica de sociedade capitalista dependente e nossa inserção subalterna na divisão internacional do trabalho. Mais incisivamente, os setores denominados de atrasados, improdutivos e informais se constituem em condição essencial para a modernização do núcleo integrado ao capitalismo orgânico mundial.

Explicitado de outra forma, os setores modernos e integrados da economia capitalista (interna e externa) alimentam-se e crescem apoiados e em simbiose com os setores atrasados. Assim, para Oliveira, a persistência da economia de sobrevivência nas cidades e uma ampliação ou inchaço do setor terciário ou da "altíssima informalidade", com alta exploração de mão-de-obra de baixo custo, foram funcionais à elevada acumulação capitalista, ao patrimonialismo e à concentração de propriedade e de renda.

Mais de trinta anos após a publicação do livro Crítica à Razão Dualista (1972), Oliveira (2003) o reedita com um capitulo de atualização: 'O ornitorrinco'. Neste capítulo, ele faz a síntese emblemática das mediações do tecido estrutural de nosso capitalismo dependente e subordinado aos centros hegemônicos do capitalismo e dos impasses a que fomos sendo conduzidos no presente.

A metáfora do ornitorrinco nos traz, então, uma particularidade estrutural de nossa formação econômica, social, política e cultural, que nos transforma num monstrengo em que a 'exceção' se constitui em regra, como forma de manter o privilégio de minorias. 
O ornitorrinco é isso: não há possibilidade de permanecer como subdesenvolvido e aproveitar as brechas que a Segunda Revolução Industrial propiciava; não há possibilidade de avançar, no sentido da acumulação digital-molecular: as bases internas da acumulação são insuficientes, estão aquém das necessidades para uma ruptura desse porte. (...) O ornitorrinco capitalista é uma acumulação truncada e uma sociedade desigualitária sem remissão. (Oliveira, 2003:150)

As relações de poder e de classe que foram sendo construídas no Brasil, observa Oliveira, permitiram apenas parcial e precariamente a vigência do modo de regulação fordista tanto no plano tecnológico quanto no plano social. Da mesma forma, a atual mudança científico-técnica de natureza digital-molecular, que imprime uma grande velocidade à competição e à obsolescência dos conhecimentos, torna nossa tradição de dependência e cópia ainda mais inútil.

O mostrengo configura o presente de forma emblemática para uma sociedade que se mantém entre as 15 de maior PIB do mundo, na qual um dos setores que mais contribuíram para a meta de superávit primário de mais de 5\% em novembro de 2005, que expressa uma garantia para os bancos credores, é o agronegócio. Ao mesmo tempo, estamos um século atrasados na efetivação da reforma agrária e convivendo com aproximadamente quatro milhões de famílias (vinte milhões de pessoas) nos acampamentos dos sem-terra.

A transição inconclusa da década de 1980 e a adesão subordinada ao Consenso de Washington a partir do governo Collor - mas realizado sobretudo no governo Fernando Henrique Cardoso e agora no governo Lula -, longe de apontar para mudanças estruturais que nos permitissem romper a construção da sociedade 'que se ergueu pela desigualdade e se alimenta dela', indica seu aprofundamento.

\section{A opção PELA tRANSFERÊNCIA E PELA CóPIA de teCNOLOGIA, A EDUCAÇÃO E A FORMAÇÃo PARA O TRABALHO SIMPLES E A 'INSERÇÃo' SOCIAL PRECÁRIA}

O desafio para romper com a modernização conservadora e dar um salto na constituição de um projeto nacional popular de desenvolvimento para mudar a sociedade, que se constituiu 'pela desigualdade e se alimenta dela', implica enorme esforço de investimento em educação, ciência e tecnologia e em infra-estrutura. A exigência mínima para isso, para não cair na ideologia do 
capital humano, além das reformas sociais de base (agrária, tributária, jurídica e política), é a existência de um substancial fundo público com controle democrático da sociedade.

O que indicamos é que há uma política fiscal predatória, assentada em impostos regressivos, para o pagamento exorbitante de juros da dívida interna e externa. A tese da separação ou da autonomia do econômico ou do Banco Central em relação à ação política é, em definitivo, como mostra Oliveira, a tentativa do capital de eliminar o sujeito e, mediante o ideário neoliberal e da globalização, eliminar "o consenso de que somos uma Nação e não um conglomerado de consumidores" (Oliveira, 2005:70). O salto não só foi adiado como também não está na agenda, nem mesmo na do operário que se tornou presidente.

O pensamento neoliberal assumido pela classe dominante brasileira traduzido pela tese do ajuste mediante a reforma do Estado, pelas privatizações do patrimônio público e a ampliação do poder do capital sobre o trabalho, pela derrocada dos direitos trabalhistas e pela internacionalização da economia sob o jugo monetarista e fiscal em nome do pagamento dos serviços da dívida externa - anulou o esforço logrado "por uma industrialização à marcha forçada" (Oliveira, 2005:65). A nova pedagogia da hegemonia do capital, nos termos postos por Neves (2005), busca, em nosso meio, naturalizar o ideário da globalização e de nossa inserção subalterna na divisão internacional do trabalho.

A síntese do pensamento do economista Paulo Renato Souza, ministro da Educação por oito anos no governo Fernando Henrique Cardoso, feita pela revista Exame com base em uma conferência proferida para empresário logo no início de sua gestão, expressa de forma cabal o pensamento e a cultura política da classe burguesa brasileira na sua vocação de subalternidade e de associação consentida.

Segundo o ministro, a ênfase no ensino universitário foi uma característica de um modelo de desenvolvimento auto-sustentado despugado (sic) da economia internacional e hoje em estado de agonia terminal. Para mantê-lo era necessário criar uma pesquisa e tecnologia próprias, diz Paulo Renato. Com a abertura e globalização, a coisa muda de figura. O acesso ao conhecimento fica facilitado, as associações e joint ventures se encarregam de prover as empresas dos países como o Brasil do knowhow que necessitam. "Alguns países como a Coréia chegaram a terceirizar a universidade", diz Paulo Renato. "Seus melhores quadros vão estudar em escolas dos Estados Unidos e da Europa. Faz mais sentido do ponto de vista econômico." (Exame, 1996:46) 
Essa postura evidencia que a opção pela cópia da tecnologia e não pela sua produção, que define a nossa posição na divisão internacional e a conseqüente supremacia do investimento na reprodução do trabalho simples, não é dominantemente uma imposição externa, mas sobretudo uma escolha interna do modo como a classe dominante brasileira alimenta e reproduz o 'ornitorrinco' que somos.

Giovanni Arrighi (1998) traduz o significado dessa opção de projeto de país. Num balanço do cenário internacional do fim do século XX, conclui que há um conjunto de países que constituem o núcleo orgânico das economias capitalistas, um grupo periférico e um grupo semiperiférico. O núcleo orgânico é o lugar privilegiado onde se realizam as 'atividades cerebrais', associadas ao fluxo de inovação envolvendo novos métodos de produção, novas fontes de suprimento e novas formas de organização. Trata-se de países com alto investimento em educação, ciência e tecnologia. Os núcleos periférico e semiperiférico são os que realizam as atividades dominantemente 'neuromusculares'. Trata-se de países de pouquíssima inovação e investimento em educação, ciência e tecnologia.

O significado político, econômico, social e cultural do modo de pensar de Paulo Renato Souza, expressão dominante da classe burguesa e de seus intelectuais, não só inviabiliza a construção de um projeto nacional autônomo como também traz para a sociedade enormes danos. Como mostra Altvater (1995), a tecnologia não se transfere sem elevados custos econômicos para o meio ambiente e, especialmente, para a vida e a saúde dos trabalhadores.

O parco investimento em ciência e tecnologia no Brasil pode ser evidenciado pelos dados fornecidos em recente exposição para empresários brasileiros por dois técnicos do Banco Mundial: Carl Dahlman e Cláudio Frischtak. Com base em estudos do Banco Mundial, eles revelaram que o Brasil concorre com $1,6 \%$ da produção científica internacional e responde apenas por $0,0019 \%$ das patentes internacionais que se vinculam à criação de novas tecnologias. ${ }^{25}$

Esse dado é revelador de um capitalismo dependente que configura um processo de desenvolvimento e de industrialização urbano-industrial truncados com a dominância de atividades 'neuromusculares' e, como conseqüência, a hipertrofia da formação para o trabalho simples da maior parte da força de trabalho e de uma pequena parcela para o trabalho complexo que demanda domínio das bases científicas e tecnológicas - mormente para os setores integrados na base digital-molecular representados especialmente por grandes empresas multinacionais. 
Que tipo de projeto de educação escolar e de formação técnico-profissional é necessário para uma sociedade que, ao mesmo tempo, moderniza o arcaico e convive com o atraso de determinados setores, a hipertrofia do trabalho informal, a precarização do trabalho formal e o analfabetismo? Esses fenômenos não foram impeditivos ao tipo de desenvolvimento protagonizado pela classe dominante. Pelo contrário, o seu projeto de desenvolvimento se ergueu a partir da desigualdade e se alimenta dela.

A resposta a essa questão, uma vez mais, nos remete à atualidade da análise de Gramsci (1979) quando relacionava o projeto de sociedade com o projeto educacional. Para o pensador italiano, a questão da escola e de sua qualidade não é sobretudo um problema de currículo ou de formação dos professores, mas sim de que a sociedade coloque a educação como problema.

Podemos sustentar que, definitivamente, a educação escolar básica (fundamental e média), pública, laica, universal, unitária e tecnológica que desenvolva as bases científicas da societas rerum (conhecimentos científico para o domínio e a transformação racional da natureza) e da societas hominum (consciência dos direitos políticos, sociais, culturais e capacidade de organização para atingi-los) a que se refere Gramsci (1979) nunca se apresentou como problema para a classe dominante brasileira, exatamente por uma questão de classe. Mas igualmente, por sua cultura e mentalidade escravocrata, colonizadora, e por sua associação subordinada ao grande capital, nunca se apresentou de fato, e sim apenas de forma retórica e moralista, nem mesmo uma escolaridade e formação técnicoprofissional para a maioria dos trabalhadores de modo a prepará-los para o trabalho complexo que os tornasse, como classe detentora do capital, em condições de concorrer com o capitalismo central.

Se, como assinalamos, a vigência do modo de regulação fordista, tanto no plano tecnológico quanto no plano social, foi parcial e precária e, do mesmo modo, nos situamos de forma ainda mais parcial e precária na mudança científico-técnica de natureza digital-molecular, os nexos entre ciência, produção, trabalho, cultura e vida e as demandas de educação e de formação técnico-profissional tendem a ser, também, parciais e precários. Por isso faz sentido a tese de Antonio Candido que, analisando a questão da cultura e da educação na Revolução de 1930, afirma que, por não ter havido uma efetiva revolução, as reformas educacionais subseqüentes não resolveram o problema da educação. São as revoluções verdadeiras que possibilitam as reformas do ensino em profundidade, de maneira a torná-lo acessível a todos, promovendo a igualização das 
oportunidades (Candido, 1984). Para Candido, somente Cuba, na América Latina, enfrentou o problema da educação e o resolveu.

Numa direção similar, Florestan Fernandes (1991) chega a uma conclusão em relação ao debate sobre educação na Constituição de 1988: a educação nunca foi algo de fundamental no Brasil, e muitos esperavam que isso mudasse com a convocação da Assembléia Nacional Constituinte. Mas a Constituição promulgada em 1988, confirmando que a educação é tida como assunto menor, não alterou a situação.

O desfecho da aprovação da Lei de Diretrizes e Bases e do Plano Nacional de Educação, em ambos os casos derrotando as forças vinculadas a um projeto nacional popular que postulava mudanças estruturais na sociedade e na educação, veio confirmar ao longo da década de 1990 que permanecem inalteradas, na substância, no atual governo, as teses de Antônio Cândido e Florestan Fernandes. O analfabetismo permanece alto. A universalização do ensino fundamental se efetiva dentro de uma profunda desigualdade intra e entre regiões e na relação cidade-campo. O Brasil é o país econômica e politicamente mais importante da América Latina e o único em que o ensino médio não é obrigatório. Ele constitui uma ausência socialmente construída na sua quantidade e qualidade, o que é o indicador mais claro da opção da formação para o trabalho simples e da não preocupação com as bases da ampliação da produção científica, técnica e tecnológica. Aproximadamente $46 \%$ dos jovens têm acesso ao ensino médio, sendo que mais da metade deles o fazem no turno noturno e, grande parte, na modalidade de supletivo. No campo, apenas $12 \%$ freqüentam o ensino médio na idade e na série correspondentes.

O coroamento da visão imediatista, não estratégica e anacrônica do pensamento dominante dos interesses do capital revela-se pelo dispositivo legal que reduziu de 18 para 16 anos a a idade limite para realizar exames supletivos na política de Educação de Jovens e Adultos. ${ }^{26}$ Trata-se de um movimento inverso ao dos países do capitalismo central em que, nas últimas décadas, a obrigatoriedade do Estado com a educação escolar regular dos jovens se estende até os 18 anos. O indicador derradeiro é o mercado privado do ensino superior e a hegemonia do pensamento empresarial se alastrando em todos os níveis (Neves, 2002a). A universidade pública formadora do trabalho complexo foi se privatizando internamente e se mantém como pública destroçada.

O balanço crítico das reformas e das políticas educacionais, sob a égide do modelo societário neoliberal a partir da década de 1980 - de acordo com o 
enfoque teórico aqui assumido e que explicita a função social que a classe dominante detentora do capital confere à escola e à educação técnico-profissional no seu conteúdo, no método e na forma, para a manutenção estrutural do projeto de uma sociedade capitalista dependente -, foi realizado de forma sistemática por Lúcia Neves e o Coletivo de Estudos de Política Educacional e, também, pelas pesquisas que realizamos, conjuntamente com Maria Ciavatta e, mais tarde, com Marise Ramos, Vera Corrêa, mestrandos e doutorandos do Programa de Pós-Graduação em Educação da Universidade Federal Fluminense. ${ }^{27}$

A síntese dessas análises sinaliza uma relação entre a regressão das relações sociais e os processos de mercantilização da educação no seu plano institucional e no seu plano pedagógico. Há uma travessia da ditadura civilmilitar para uma ditadura do mercado no ideário pedagógico (Frigotto, 2002, 2005b). No âmbito do pensamento pedagógico, o discurso em defesa da educação é dominantemente retórico ou apresentado de forma inversa tanto na ideologia do capital humano (conjuntura da década de 1960 a 1980) quanto no que diz respeito às teses, igualmente ideológicas, da sociedade do conhecimento, da pedagogia das competências e da empregabilidade (década de 1990).

No primeiro caso, a noção de capital humano mantinha, no horizonte da classe dominante, a idéia da educação como forma de integração, ascensão e mobilidade social. No segundo caso, com a crescente incorporação de capital morto na produção, com a ciência e a tecnologia como forças produtivas diretas, com a ampliação do desemprego estrutural e de um contingente de trabalhadores supérfluos, as noções de sociedade do conhecimento, qualidade total, cidadão produtivo, competências e empregabilidade indicam que não há lugar para todos e que o direito social e coletivo se reduz ao direito individual (Frigotto, 1984; Frigotto, Ciavatta \& Ramos, 2005b, 2006; Ramos, 2001). Como mostra Castel (1998), transitamos de políticas de integração social, como direito social e subjetivo construído na luta de classes, para políticas de inserção precária. Essa transição se configura no Brasil de hoje de forma profunda e nos explicita, de modo claro, o resultado da opção da classe burguesa brasileira por sua inserção consentida e subordinada no governo do grande capital, assim como mostra nosso papel subalterno na divisão internacional do trabalho com a hipertrofia da formação para o trabalho simples. Como afirma Neves (2000: 180-181), a natureza das políticas educacionais em jogo dependia de duas ordens:

a) das repercussões econômicas e político-sociais do desenvolvimento do novo paradigma produtivo no espaço nacional; b) dos requisitos técnicos e 
ético-políticos do novo conteúdo do trabalho industrial; c) dos desdobramentos da luta entre a consolidação da hegemonia neoliberal e a construção de uma contra-hegemonia democrática de massa.

O pêndulo não se movimentou na direção das forças que lutam por um projeto nacional popular e democrático de massa e as conseqüentes reformas estruturais, o que implicaria um projeto de educação escolar e de formação técnico-profissional dos trabalhadores que desenvolvessem, para o universo de jovens e adultos, as bases científico-técnicas para o trabalho complexo - condição para uma inserção ampla na forma que assume o processo de produção industrial-moderno, dominantemente digital-molecular.

Cabe ressaltar que a opção contrária à expectativa da classe trabalhadora pelo governo Lula na direção de reformas estruturais não é apenas um golpe e uma derrota do seu governo para com a classe de sua origem, mas a fragmentação e a desorganização da classe trabalhadora, com conseqüências profundas para suas lutas históricas. ${ }^{28}$

Assim chegamos ao Brasil de 2005 reproduzindo, de forma ampliada, o monstrengo social configurado pela metáfora do ornitorrinco e traduzido por uma pirâmide social em que, como mostram os estudos de Pochmann (2004), se configuram um empobrecimento e esvaziamento da classe média, a polarização de lados opostos da pirâmide social com a elevação da concentração de renda e de capital e a ampliação dos inseridos precariamente na base da pirâmide. Isso é resultado, para Pochmann, da política monetarista e fiscal que de um lado dá garantias aos ganhos do capital, mormente o capital financeiro, e de outro sustenta programas de renda mínima para os grandes contingentes como estratégia de diminuição da indigência e da pobreza absoluta.

As políticas de educação escolar e de formação técnico-profissional que se consolidaram na hegemonia neoliberal buscaram, não sem contradições, a produção das qualificações necessárias ao funcionamento da economia nos setores restritos que exigem trabalho complexo, o alargamento da formação para o trabalho simples e a formação de quadros para a elaboração e a disseminação da pedagogia da hegemonia. ${ }^{29}$ Trata-se de produzir o pacote de competências adequadas à formação do 'cidadão produtivo' ajustado técnica e socialmente às demandas do capital. Um cidadão que acredite que a ele não compete ser sujeito político (Frigotto \& Ciavatta, 2003).

Como já assinalamos, as reformas educativas da década de 1990, não alteradas na substância no governo Lula, expressam nos conteúdos curriculares, 
nos métodos de conhecimento e na forma antidemocrática de impô-las o projeto de escola e de formação profissional que busca cumprir esses objetivos. Os convênios com universidades federais ou transferências de recursos para instituições privadas, com a rede dos Centros Federais de Educação Tecnológica (Cefets), e o foco, especialmente do Serviço Nacional de Aprendizagem Industrial (Senai), nos setores de ponta da economia garantem a formação para o trabalho complexo e a integração de um reduzido número de trabalhadores no mercado formal. Mas a política da escola básica pública, "que cresce para menos" (Algebaile, 2002), à medida que se retira dela a função de produção das bases científico-técnicas, sociais e culturais e que ela se amplia como espaço de alívio para a pobreza e de assistência social, contraria, na prática, o discurso vazio dos empresários que reclamam educação de qualidade, mas a condicionam à formação para o trabalho simples. Completam essa função - a de formar para o trabalho simples - os sistemas paralelos que se multiplicam, públicos e privados, de formação técnico-profissional aligeirada.

Num outro patamar situam-se os programas que articulam a escola e a qualificação técnico-profissional mais diretamente aos processos de 'inserção social' precária. Os dois maiores programas desse tipo são o Plano Nacional de Qualificação do Trabalhador (Planfor) ${ }^{30}$ - que no governo Lula se transformou em Plano Nacional de Qualificação (PNQ) e se inscreve na política de emprego e renda mínima para desempregados, subempregados, força de trabalho supérfluo - e o Bolsa Escola, que pretende atingir 11 milhões de famílias. Paralelamente situa-se o programa de primeiro emprego para jovens vítimas daquilo que Castel $(1998)^{31}$ caracterizou como "desemprego de inserção" para designar os jovens que buscam emprego e não conseguem. No Brasil, os dados das pesquisas de Pochmann $(1998,1999)$ indicam um desemprego de inserção de 42,3\% dos jovens. Nessa perspectiva, ganharam grande ênfase política ultimamente no governo Lula o Programa Nacional de Inclusão de Jovens (Projovem), a Escola de Fábrica e o Programa de Educação para Jovens e Adultos (Proeja).

O Fundo de Amparo ao Trabalhador (FAT) constitui-se num lugar de acirrada disputa pelo sindicalismo em profunda crise golpeado pelas políticas neoliberais e de mundialização do capital e por uma profusão de Organizações Não-Governamentais (ONGs) e escritórios de intermediação para financiar programas e projetos de formação e qualificação dos trabalhadores. No caso do sindicalismo, o volume de recursos apropriados e a natureza dos programas de formação e qualificação variam de central para central. Souza (2002) nos traz 
uma análise crítica densa sobre o sentido e o significado das propostas de trabalho e educação protagonizadas pela Central Única dos Trabalhadores (CUT), pela Conferência Nacional das Classes Trabalhadoras (Conclat), pelas Gerais dos Trabalhadores (CGTs) e a Força Sindical. ${ }^{32}$

As referências de estudos e pesquisas que serviram de base para a análise até aqui empreendida têm sua filiação teórica na compreensão dialética da realidade brasileira e, portanto, nos permitem perceber que há contradições e se travam lutas pelos projetos de sociedade e de educação. É com essa compreensão que a batalha das idéias colocou na agenda dos debates da década de 1980 a concepção de educação escolar pública, universal, laica, unitária e politécnica ou tecnológica ${ }^{33}$ como precondição de uma qualificação ou formação técnicoprofissional que supere a tradição do adestramento e articule conhecimento científico e filosófico e trabalho, cultura e vida.

As questões que se impõem são: qual a materialidade dentro da qual se fundamente a concepção de educação escolar unitária, politécnica e/ou tecnológica? O que explica que essa concepção não tenha ganhado espaço concreto na política e na prática educativa e, da década de 1990 em diante, tenha arrefecido até mesmo na batalha das idéias? Quais os ganhos desse embate que permanecem e por que a concepção de educação unitária, politécnica e/ou tecnológica se constitui em tema crucial e necessário na disputa do projeto societário e educacional? Essas questões vincam o eixo central de um projeto de pesquisa que estamos desenvolvendo ${ }^{34}$ a partir das pistas sugeridas pela conclusão da pesquisa sobre o estado-da-arte do ensino médio técnico e da educação profissional nas décadas de 1980 e 1990 (Frigotto \& Ciavatta, 2005). Com base no que até o momento a análise nos permite avaliar e da qual deriva este texto, destacamos alguns aspectos de tais questões.

Pode-se afirmar que a concepção de educação escolar unitária e politécnica ou tecnológica - cujos eixos centrais são o não-dualismo e a fragmentação e a união entre formação intelectual e produção material, articulando teoria e prática no desenvolvimento dos fundamentos ou bases científicas gerais de todos os processos de produção - não surgiu no debate e na disputa de projetos de sociedade e educacionais de forma arbitrária ou como idéias fora do lugar. Isso por três razões articuladas.

Primeiramente pela incorporação mais ampla, na década de1980, do pensamento de Marx e, em especial, de Gramsci, nas ciências sociais e na educação, em particular em alguns programas de pós-graduação. Esse aporte teórico 
permitiu a ampliação da formação de um número crescente de intelectuais que aprofundaram e difundiram a compreensão das contradições da sociedade capitalista e de sua especificidade no Brasil; e também da necessidade de, a partir do desenvolvimento do capitalismo, suas contradições e sua crítica, superar a proposta burguesa de sociedade e de educação. Por essa via, não se desvincula projeto societário e de educação e formação técnico-profissional.

A segunda razão diz respeito às mudanças científico-técnicas vinculadas aos processos produtivos. O Brasil transitou de uma sociedade dominantemente agrícola, com a maior parte da população no campo, para uma sociedade dominantemente urbano-industrial. Malgrado, como vimos, tratar-se de uma industrialização parcial e truncada, criaram-se necessidades e demandas novas no campo da educação escolar e da formação técnica para um contingente de trabalhadores necessários ao trabalho complexo em todos os ramos da produção. Há, pois, uma base material nos processos produtivos que sustentam a disputa de sua direção: continuidade de um desenvolvimento urbano-industrial truncado, para poucos, subordinado e dependente da lógica do capital mundializado, ou um projeto nacional popular e democrático que permita a integração efetiva nos direitos sociais de uma enorme massa até agora excluída ou inserida precariamente.

A tese da 'educação polivalente' defendida pelos intelectuais e aparelhos de hegemonia do capital e o combate à concepção de 'educação politécnica' indicam tanto a necessidade de formação de trabalhadores com maior base dos princípios científicos da produção quanto a consciência do que estava em disputa. Daí o combate sistemático desses intelectuais e aparelhos de hegemonia à tese da educação escolar unitária e politécnica.

Por fim, a conjuntura da década de 1980, com as lutas pela redemocratização, fim da ditadura e início do processo constituinte, num contexto histórico diverso, permitiu fazer valer o acúmulo da esquerda (socialista ou não) de lutas e de derrotas e pequenas vitórias que se deram ao longo do século XX, entre ditaduras e golpes da classe dominante. O processo constituinte permitiu aflorar, de maneira viva, as contradições e os interesses conflitantes e antagônicos em jogo em nossa sociedade.

Foi nos grandes debates nacionais das Conferências Brasileiras de Educação e depois no Congresso Nacional de Educação (Coned), nas reuniões das entidades científicas da área, nos congressos do Sindicato Nacional de Docentes de Ensino Superior (Andes) e da Confederação dos Trabalhadores da Educa- 
ção (CNTE) que as idéias da escola pública, laica, universal, unitária e politécnica e/ou tecnológica se massificaram. A prova da importância desses debates e de sua força está no fato de que o primeiro projeto de Lei de Diretrizes e Bases levado à Câmara, pelo deputado Otávio Elísio, é a organização quase literal, em forma de artigos, de um texto de Saviani apresentado numa conferência em 1988, no qual ele expunha as idéias básicas da concepção de escola unitária e de educação politécnica (Saviani, 1988).

As razões do refluxo na década de 1990 são, sem dúvida, em grande parte de ordem conjuntural, mas só ganham compreensão mais radical no tecido estrutural das relações sociais de produção capitalistas que definiram até hoje o tipo de bloco histórico construído no Brasil e, também, na natureza da formação teórica das forças sociais que lutam por um projeto de desenvolvimento nacional popular democrático de massa. Não obstante as razões expostas, as quais mostram que o debate sobre a escola unitária e a educação politécnica não foi arbitrário e fora do lugar, pode-se sustentar que, pelo caráter estrutural das relações sociais de produção e o alcance teórico do campo da esquerda no Brasil, parodiando Marx, no debate sobre a escola unitária e politécnica, 'a frase foi além do conteúdo’. Como lembra Fiori (2002), ainda que nesse caso com diferenças, a luta pelo projeto de desenvolvimento nacional popular ao longo do século XX foi dominantemente um embate ideológico, mas que teve pouco espaço de aplicação prática.

A razão mais aguda da dificuldade estrutural do avanço - no plano das contradições do capitalismo - da educação escolar unitária e politécnica situa-se, justamente, na opção por um capitalismo dependente e subordinado que reitera o truncamento do processo urbano-industrial e que, portanto, barra a generalização da necessidade da incorporação das tecnologias avançadas de natureza digitalmolecular. A essa determinação estrutural junta-se uma conjuntura mundial de vingança do capital contra o trabalho e de um crescente monopólio da ciência e da técnica por um número cada vez menor de grupos econômicos localizados nos centros hegemônicos do capital, relegando os países periféricos dominantemente ao trabalho simples. Daí um refluxo ainda maior da necessidade de educação escolar e formação científico-técnica com bases mais complexas, terreno no qual a disputa por uma formação politécnica poderia avançar. ${ }^{35}$

O 'empate' das conquistas no capítulo da ordem econômica e social do texto constitucional, no qual o campo educativo escolar e a formação técnicoprofissional se situam, foi sendo desmontado já a partir de 1990 no governo 
Collor, com a adoção do projeto neoliberal do ajuste, mediante a reforma do Estado e a reestruturação produtiva com os processos de desregulamentação da economia, flexibilização dos direitos do trabalhador e privatizações. Esse projeto foi levado às últimas conseqüências nos oito anos do governo Fernando Henrique Cardoso.

A eleição do operário Luís Inácio da Silva, na quarta disputa, se deve em grande parte ao apoio de forças bastante heterogêneas no campo de esquerda, que historicamente lutaram para construir uma nação com a sua história, cultura, língua e valores que constituem a base de um relacionamento autônomo e soberano com outras nações e povos e a ruptura, portanto, com os processos de colonização e subserviência aos centros hegemônicos do capital. Concomitantemente, no plano interno, permanece a defesa de uma ruptura com as forças que mantêm a desigualdade abismal na sociedade brasileira em todos os âmbitos. Trata-se de atacar reformas estruturais inadiáveis. Para alguns setores dessas forças, significa lutar para ir além das relações sociais capitalistas mediante um projeto societário socialista, pois a efetiva igualdade de condições entre os seres humanos é inviável dentro do capitalismo.

Não há espaço aqui para uma síntese sequer das análises que, em grande parte, explicam o (des)caminho assumido. Assinalamos, apenas, que elas convergem para o fato de que esse (des)caminho foi sinalizado antes mesmo da eleição, quando o candidato Lula assinou a Carta aos Brasileiros, junto com todos os outros candidatos, com o compromisso de manter a política dos organismos internacionais - a política neoliberal em curso. Essa 'opção desviante' do governo Lula certamente foi e é um profundo golpe para a luta contrahegemônica no projeto de desenvolvimento nacional popular e democrático de massa e no projeto de educação escolar unitária e politécnica e/ou tecnológica - sob essas bases, uma formação técnico-profissional de novo tipo. ${ }^{36}$ Todavia, por mais duro e de conseqüências funestas para a classe trabalhadora que seja o golpe, o risco é de se render e se fixar no conjuntural, perdendo a visão tanto do legado construído quanto das possibilidades de se instalar nas contradições e seguir na luta. $\mathrm{O}$ alcance da teoria, nesse particular, é decisivo para não derivar para o pessimismo imobilizador ou para o ativismo voluntarista.

É, pois, a questão da apropriação da teoria e de sua radicalização, especialmente com base no legado de Marx e Gramsci, que pode nos permitir entender por que o ideário da escola unitária politécnica e/ou tecnológica, ao se confrontar com a estrutura de relações sociais de produção e relações políticas 
e de poder, que já esboçamos, não encontrou materialidade objetiva para uma ampla implementação. Ao mesmo tempo, mostra os ganhos e acúmulos que esse ideário permite e a necessidade de tomá-lo como pauta permanente.

A década de 1990, com a hegemonia do projeto neoliberal, na verdade mais que um refluxo na implementação, tornou mais opaca a materialidade de sua possibilidade, pela opção de continuar o truncamento de um projeto de desenvolvimento urbano-industrial de marca brasileira e de novo tipo, no qual os conhecimentos científico, filosófico, cultural, técnico e tecnológico são imprescindíveis.

Sobre a debilidade da apropriação teórica crítica, em quantidade e qualidade que a tornem uma força material efetiva pela massa de professores, pesquisadores, alunos líderes do movimento sindical e dos movimentos sociais, entendemos que ela explica em boa medida a parca incorporação prática no sistema de educação escolar e nos sistemas de formação técnico-profissional específica. A evidência disso é que até mesmo nas experiências dos governos populares assumidos pelo campo de esquerda, uns com uma duração significativa, o eixo dos projetos educativos foi mais de cunho cultural e político: escola cidadã, escola plural, escola candanga etc. Não se trata aqui de minimizar a importância do cultural e do político e o valor dessas experiências. Trata-se de mostrar que não estava incorporada - ou tinha pouquíssima ênfase - a concepção da educação escolar politécnica e/ou tecnológica. Isso significa que estavam também fora de foco a disputa pela direção do projeto urbano-industrial (de tipo original) e as exigências de formação científico-técnica que ele demanda. Talvez fosse nessa direção que apontava a advertência de Florestan Fernandes sobre o risco de a esquerda no Brasil estar se pautando sobre um teorismo ou subjetivismo revolucionário.

Por fim, as indicações da debilidade teórica se manifestam no claro refluxo ou quase abandono do projeto de escola unitária e politécnica e/ou tecnológica na batalha das idéias da grande maioria dos educadores, pesquisadores e intelectuais ligados ao movimento sindical e aos movimentos sociais. Essa debilidade se evidencia pelo fato de que o debate de tais idéias se fixou quase exclusivamente na crítica, sem dúvida imprescindível, mas não suficiente, à agenda neoliberal e às demandas dos conhecimentos e da nova subjetividade do trabalhador com relação à reestruturação produtiva sob a ótica do capital. A não-continuidade do embate propositivo, mesmo que no campo das idéias, dentro da indicação metodológica gramsciana de repetir de várias formas as mesmas idéias, possa atingir a grande massa popular, deixou o terreno aberto para a pedagogia da hegemonia do capital. 
A ideologia das competências, da empregabilidade, da qualidade total e da formação técnico-profissional adestradora e fragmentada foi tomando 'as mentes e os corações' de professores e das classes populares. Trata-se da incorporação da ideologia neoliberal. A debilidade teórica se evidencia especialmente no ambiente universitário, onde se formam intelectuais de vários tipos, com a ampla penetração do pós-modernismo e de seus derivados do multiculturalismo, como expressão ideológica e cultural do capitalismo tardio (Jameson, 1996).

Quais os ganhos que permanecem das questões postas pelo debate da educação escolar unitária, politécnica e/ou tecnológica? Sem dúvida há ganhos, e são eles que nos permitem perceber que esse ideário foi dominantemente derrotado a partir da década de 1990, mas de forma alguma fracassou e está perdido. Essa leitura nos permite parodiar o historiador Eric Hobsbawm (1992b) em sua referência à derrota do socialismo realmente existente: depois disso tudo, é preciso renascer das cinzas.

Há dois ganhos não facilmente reversíveis. A explicitação clara, e em grande parte escrita, na sociedade brasileira, demonstra a disputa entre projetos de sociedade e de educação antagônicos: projeto do capital e seus intelectuais e projeto da classe trabalhadora - pouco visível a olho nu, mas cada vez mais violentada - e seus intelectuais. Essa demarcação tem um profundo sentido político e cultural contra o senso comum que a classe dominante historicamente incute nas classes populares sobre nossa 'natural' tendência à conciliação, vivência pacífica e de colaboração entre capital e trabalho.

O segundo ganho, particularmente para o campo da esquerda, e que qualifica o embate mostrado, é de que o ideário da escola unitária, politécnica e/ ou tecnológica trouxe para o debate teórico e político-prático a questão da relação entre o trabalho, a educação escolar, a formação técnico-profissional e a produção material. ${ }^{37}$ Isso significa demarcar como fundamental na luta socialista a direção moral e intelectual do projeto da sociedade urbano-industrial, darlhes uma marca original ou nova no horizonte das contradições entre o avanço das forças produtivas e o caráter cada vez mais anti-social do sistema capital e não no terreno do 'quanto pior melhor'.

Esses dois ganhos têm peso extraordinário para uma agenda que nos permita 'renascer das cinzas'. Buscaremos destacar alguns aspectos dessa agenda como conclusão. 


\section{A Título de Conclusão: contradição e utopia COMO HORIZONTES DE SUPERAÇÃO DO PESSIMISMO DA RAZÃO}

Diferentemente de uma conclusão no seu sentido estrito, pela natureza de síntese e de eixo para o debate que caracteriza estas reflexões, buscaremos destacar alguns pontos que nos permitam 'renascer das cinzas' mediante uma agenda contra-hegemônica ao que Lúcia Neves denominou de "a nova pedagogia da hegemonia" (Neves, 2005) como estratégia do capital de educar para consenso do seu projeto societário. O ponto central dessa agenda, pelo que expusemos até aqui, situa-se no campo da radicalização da teoria e na disputa de corações e mentes no campo ético-político e ideológico.

Uma lição da história, sintetizada por Lenin, é de que sem teoria revolucionária não há possibilidade de projeto revolucionário. No campo teórico, o desafio candente é o de radicalizar o legado do materialismo histórico como o referencial capaz de dar a grande parte da esquerda intelectual e militante brasileira os fundamentos para superar o duplo viés incorporado do marxismo ocidental: o estruturalismo francês e a análise antinômica da realidade histórica, o primeiro apontado por Anderson (1985) e o segundo por Jameson (1997).

Esse aprofundamento se constituirá, em primeiro lugar, num instrumento potente de crítica ao pensamento único e ao canto da sereia que seduziu grande parte da esquerda do mundo e brasileira, o pós-modernismo e sua visão fragmentária e multiculturalista do capitalismo tardio, desarticulando-os pela demonstração histórico-empírica. Em segundo lugar e concomitantemente, poderá constituir-se em instrumental potente para identificar as contradições fundamentais, em todas as esferas da sociedade, instalar-se nelas e trabalhá-las para o avanço do projeto societário e de educação escolar e formação científico-técnica contra-hegemônicos.

Por essa via se poderá entender que a disputa, em seu núcleo duro, situase no plano das relações sociais de produção e no controle da natureza dos vínculos entre ciência, técnica, tecnologia e produção material, ainda que elas se expressem e as massas tomem consciência delas no plano político-ideológico e cultural. Trata-se da centralidade da disputa da natureza, sentido e significado do projeto de desenvolvimento urbano-industrial e das necessidades de uma classe trabalhadora científica, técnica, filosófica, cultural e politicamente com 
sólidas bases que a tornem capaz de viabilizar esse projeto. Em termos gramscianos, isso implica, para a esquerda, fazer um inventário crítico sobre a conformação de sua cultura e do seu pensamento elitistas caracterizados pelo desprezo (dissimulado) do trabalho material produtivo e da formação técnica e tecnológica, como base para um esforço sistemático na sua superação.

Como conseqüência, a superação de um processo de educação escolar retórico, generalista, culturalista e escolástico ou da educação escolar dualista, fragmentária, e da formação profissional adestradora da classe dominante, expressão de um processo de desenvolvimento dependente e trucado, implica, por parte da esquerda, a disputa pela construção de um projeto de desenvolvimento nacional popular e de massa e o desenvolvimento de bases científicas e tecnológicas de natureza digital-molecular que abram um tecido de materialidade histórica que situe as contradições.

No âmbito ético-político, cultural e de embate ideológico, a tarefa é de se apropriar do que a teoria social nos fornece e, pedagogicamente, aprender da direita, como nos ensina Gramsci, a repetir, de diferentes formas e por todos os meios, 'verdades históricas' contra-hegemônicas. Entre essas verdades, devemos repetir, em todos os espaços:

- que a classe burguesa brasileira, associada de forma subordinada à classe burguesa dos centros hegemônicos do capitalismo, para se manter tem que destruir, cada vez mais, direitos dos trabalhadores: emprego, saúde, educação, habitação, transporte, vida e lazer e degradar o meio ambiente, solapando as bases da vida;

- que, como observa Hobsbawm, “os socialistas estão aqui para lembrar que as pessoas devem vir em primeiro lugar e não a produção. As pessoas não podem ser sacrificadas" (Hobsbawm, 1992a:268). Ou seja, que o superávit primário, a blindagem do Banco Central, o lucro astronômico do sistema financeiro, a propriedade de latifúndios, a privatização da educação etc. não podem sacrificar a vida de milhões de pessoas.

- que não são as ONGs, o limbo do terceiro setor, as igrejas, o voluntariado, o empreendedorismo, o assistencialismo, os bancos privados que podem garantir direitos sociais, mas sim uma esfera pública democrática, que tem seu locus mais universal no Estado, ainda que não nesse Estado atual, já que "o mercado produz desigualdade tão naturalmente como combustíveis fósseis produzem poluição do ar” (Hobsbawm, 1992a:264). 
A questão permanente para a esquerda é a dura tarefa da travessia para uma sociedade que vá além do capital - o socialismo. Essa travessia, se a teoria social e educacional for saturada de historicidade, se dará pelo projeto da utopia da sociedade socialista e na capacidade de identificar e atuar no terreno das contradições, dentro do capitalismo que vivemos hoje, em todos os espaços da sociedade política e da sociedade civil. Nesse âmbito, não há ação humana pura ou imaculada (prerrogativa metafísica), mas risco de erro, avanços e recuos.

Em termos concretos para a esquerda brasileira, significa ser capaz de identificar, hoje, no Estado brasileiro e em seus poderes anacrônicos e dominantemente a serviço da reprodução do capital, na decepção do governo Lula e na Central Única dos Trabalhadores, no sistema educacional etc., espaços contraditórios e forças sociais que possam fazer avançar as mudanças que alteram e não reproduzem a ordem vigente e destroçar a classe dominante que se mantém nos seus privilégios na reprodução da desigualdade. A tendência de ver pura negatividade nesses espaços advém de uma análise mecânica, reducionista, antinômica, metafísica e, portanto, não-dialética da realidade. Essa tarefa se situa tanto no ataque a questões estruturais quanto na solução a ela articulada, de questões conjunturais.

No plano das reformas estruturais, isso implica a necessidade inadiável de se centrar nas lutas pela reforma agrária e pela taxação das grandes fortunas, com o intuito de acabar com o latifúndio e a altíssima concentração da propriedade da terra; pela reforma tributária, com o objetivo de inverter a lógica regressiva dos impostos, em que os assalariados e os mais pobres pagam mais, corrigindo assim a enorme desigualdade de renda; pela suspensão ou renegociação, noutras bases, da dívida externa e interna; pelo controle social, mediante uma esfera pública efetiva, e não a autonomia do Banco Central.

No âmbito conjuntural, concomitantemente, há problemas cruciais a serem resolvidos cuja dramaticidade humana implica políticas distributivas imediatas, não como caridade, alívio à pobreza, paternalismo, mas como direito do animal humano à vida. Essas políticas, além de terem a necessidade de um controle social público para não se transformarem em clientelismo e paternalismo (traços fortes de nossa cultura política), não podem ser permanentes. Por esse motivo, como conclui Hobsbawm (1992b:270)

em seu convite para 'renascer das cinzas', isso implicará "uma investida contra as fortalezas centrais da economia de mercado de consumo. Exigirá não apenas uma sociedade melhor que a do passado, mas como 
sempre sustentaram os socialistas, um tipo diferente de sociedade. (...) É por esse motivo que (o socialismo) ainda está no programa

Embora essa seja uma tarefa dos socialistas de todo o mundo, no Brasil ela nos cabe, e não podemos delegá-la. No atual momento de profunda crise da esquerda, a direção da ação política mais fecunda não se dá no aparelho do Estado em sentido estrito, nem na disputa das siglas dos partidos políticos de esquerda, ainda que também ali tenha que se dar a disputa contra-hegemônica. A herança teórica de Marx e Gramsci nos remete ao partido ideológico e revolucionário, cujo centro é a disputa nos aparelhos de hegemonia em todos os espaços da sociedade civil para "construir uma intersubjetividade revolucionária, ou seja, um conjunto de sujeitos que são plurais mas que convergem e se unificam na luta contra o capital" (Coutinho, 2002:38). Vale dizer: uma convergência na luta de classes.

Ao contrário daquilo que a 'nova pedagogia da hegemonia' do capital nos quer fazer crer, que a política é tarefa de especialistas e técnicos, cabe mobilizar as massas, os movimentos sociais do campo e da cidade para o exercício permanente da política no combate à classe burguesa brasileira, aos seus intelectuais e gestores de seus negócios e aos governos que governam em seu nome ou que se situam numa posição dúbia e oportunista do poder pelo poder. Como lembra Oliveira (2005:70), os pensadores clássicos das ciências sociais do Brasil nos ajudaram a "descobrir o Brasil e 'inventar' uma Nação". Em meio à violência do pensamento único do neoliberalismo e do caminho ou 'opção desviante' do governo Lula e dos conseqüentes destroços no campo da esquerda, o desafio crucial do pensamento crítico, articulado a movimentos e lutas sociais, é de 'reinventar a Nação brasileira' e, portanto, estabelecer um projeto de desenvolvimento nacional popular democrático e de massa 'sustentável' que tenha os germens do novo. Um “desenvolvimento sustentável", como sublinha Hobsbawm, "que não pode funcionar por meio do mercado, mas operar contra ele".

Para que essa agenda tenha consistência histórica e efetivo poder revolucionário, não basta o convencimento da classe trabalhadora da justeza e da necessidade da luta contra o projeto do capital. É preciso, como assinala Gramsci, a elevação moral e intelectual das massas. Por isso a agenda da luta da esquerda, independentemente de onde atue, tem que afirmar como estratégico e prioritário o direito da educação escolar básica (fundamental e média) unitária e politécnica 
e/ou tecnológica, que articule conhecimento científico, filosófico, cultural, técnico e tecnológico com a produção material e a vida social e política, para todas as crianças e os jovens. Articulada a essa formação básica está a formação técnico-profissional dos adultos, como um direito social de prosseguir se qualificando e como possibilidade de se inserir na produção dentro das novas bases científico-técnicas que lhes são inerentes.

\section{NOTAS}

${ }^{1}$ Por estrutura econômico-social entendemos, como a conceitua Karel Kosik, o "conjunto de relações sociais que os homens estabelecem na produção e no relacionamento com os meios de produção [que] pode constituir a base de uma coerente teoria das classes e ser o critério objetivo para a distinção entre mutações estruturais - que mudam o caráter da ordem social - e mutações derivadas, secundárias, que modificam a ordem social sem porém mudar essencialmente seu caráter" (Kosik, 1986:105). Uma concepção oposta, portanto, à de 'fator econômico', derivada do economicismo e do sociologismo das abordagens positivistas e estrutural-funcionalistas da ótica burguesa de ciência e sociedade. Por isso Marx nos indica que os economistas burgueses presos às representações capitalistas percebem como se produz de dentro da relação capitalista, mas não como se produz essa própria relação. Isso implica dizer que, ao trabalharem de forma a-histórica e fenomênica a realidade social, mascaram e elidem seus fundamentos, mas também acabam dificultando a compreensão das crises dos problemas que os afetam.

${ }^{2}$ Como veremos, não existe uma linearidade entre a produção de conhecimento na experiência humana no processo de criar técnicas que 'estendem as mãos' e o conhecimento científico. O que caracteriza a especificidade deste último é sua produção acumulativa e sistemática segundo pressupostos teóricos e metodológicos próprios.

${ }^{3}$ Este texto, mesmo que possa ser lido de forma autônoma, foi produzido tendo como horizonte o conjunto das análises que o precedem no contexto do seminário sobre 'Fundamentos Filosóficos e Socio-Históricos da Educação' no Brasil hoje, organizado pela Escola Politécnica de Saúde Joaquim Venâncio, da Fundação Oswaldo Cruz. Por se tratar de um texto-síntese de um percurso de produção de pesquisa nas últimas décadas, parte das idéias aqui expressas encontra-se publicada em textos do autor ou em co-autoria. Agradeço o permanente intercâmbio crítico e a elaboração coletiva, especialmente a Maria Ciavatta, Marise Ramos, Vera Corrêa e Carlos Alexandre.

${ }^{4}$ Não é nosso objetivo analisar a especificidade do capitalismo como sociedade de classes em relação aos modos precedentes de sociedades de classe. A referência básica para essa compreensão continua sendo a obra magna de Marx, O Capital (Marx, 1983). Para uma análise sobre as origens e a especificidade do capitalismo e sua incompatibilidade orgânica com a democracia, ver Ellen M. Wood (2001, 2003). Em relação ao desenvolvimento 
histórico do metabolismo social do sistema capital e ao aguçamento exponencial de suas contradições e de sua crise estrutural, ver Mészáros (2002).

${ }^{5}$ Cabe sinalizar que o pensamento econômico inglês, a filosofia idealista alemã e o socialismo utópico francês constituem o ponto de partida sem o qual Marx e Engels não poderiam desenvolver sua teoria do processo histórico, transcendendo-o. Em relação à questão do socialismo utópico e científico, ver Engels (1985).

${ }^{6}$ Realçamos esse aspecto pois é freqüente reduzir o trabalho como princípio educativo à idéia didática ou pedagógica do 'aprender fazendo'. Para aprofundar a compreensão dessa questão, ver Saviani (1994), Manacorda (1990) e Frigotto (1985). Isso não elide a experiência concreta do trabalho dos jovens e adultos, ou mesmo das crianças, como uma base sobre a qual se desenvolvem processos pedagógicos ou a atividade prática como método pedagógico. Uma das obras clássicas sobre o trabalho como elemento pedagógico é a de Pistrak (1981).

${ }^{7}$ Para aprofundar esse aspecto central do trabalho no capitalismo, ver a síntese feita por um grupo de pesquisadores da Universidade de Brighton (Inglaterra) - Brighton Labor Process Group - do capítulo de O Capital, de Karl Marx, que trata do processo de trabalho capitalista (apud Silva, 1992).

${ }^{8}$ Por estar relacionado a necessidades humanas históricas, o trabalho humano não se separa da esfera da necessidade, mas, como insiste Kosik, ao mesmo tempo a supera e cria nela os reais pressupostos da liberdade. "A relação entre necessidade e liberdade é uma relação historicamente condicionada e variável" (Kosik, 1986:188).

${ }^{9}$ Carlos Paris produz uma densa obra que nos fornece uma detalhada análise desse processo histórico apontado por Lukács. O título ( $O$ Animal Cultural) explicita uma teleologia de um processo humano evolutivo, embora não linear, contraditório. Nesse processo destaca a ciência, a técnica e a tecnologia como atividades humanas centrais e, ao mesmo tempo, o seu potencial destrutivo e mutilador sob o capitalismo (Paris, 2002).

${ }^{10}$ Para uma análise desse processo nos termos aqui sinalizados, ver Hobsbawm (1992a, 1992b, 1995).

${ }^{11}$ Dentre os autores que permitem aprofundar e ampliar o sentido destrutivo da forma que assume o metabolismo do sistema capital em sua fase mundializada e flexível, além dos autores já citados, ver Altvater (1995), Arrighi (1998), Chesnais (1996, 1998), Harvey (2003), Hobsbawm (1995, 2000) e Jameson (1996, 2001).

${ }^{12}$ Não é nosso propósito analisar a crise estrutural do desemprego. Para um aprofundamento dessa questão e de seus efeitos sociais, ver Castel $(1997,1998)$, Forester (1997), Santos (1999), Sennett (1999).

${ }^{13}$ Nesse aspecto, registre-se que Gramsci não compartilha do pessimismo das análises de Adorno e Horkheimer sobre a cultura de massa produzida pelo sistema fordista, por ela ser eivada de um certo mecanicismo. Vale dizer que, em suas análises, eles não captam as dimensões contraditórias. 
${ }^{14}$ Captar esse movimento contraditório não tem sido o aspecto dominante nas análises em nosso meio. Trata-se de compreender os elementos básicos do processo histórico como os apresenta Marx, quando se explicita um nexo necessário entre a natureza contraditória do modo de produção capitalista e a possibilidade histórica de sua superação e a instauração do socialismo. Tal superação não se efetiva de forma determinista, porém mediante a práxis (Vázquez, 2003). O mais comum, mesmo da parte dos que se declaram filiados à tradição marxista, é efetivar análises com base na antinomia e não na contradição (Jameson, 1997). Essa debilidade no campo marxista pode estar vinculada ao que diagnosticou Perry Anderson (1985) em relação à herança do estruturalismo no marxismo ocidental. Identificar as contradições historicamente produzidas nas relações sociais capitalistas é crucial na luta contrahegemônica. Essa é uma tese central de Mao Tsé Tung sobre a luta política: identificar a “contradição principal e o principal da contradição” (Mao Tsé Tung, apud Moderno, 1979).

${ }^{15}$ Para Paris (2002:119), há uma distinção entre inovações técnicas e tecnológicas: "As primeiras pressupõem um aperfeiçoamento numa linha estabelecida de energia e de materiais - como ilustraria o desenvolvimento da navegação a vela; as segundas implicam saltos qualitativos, pela introdução de recursos energéticos e materiais novos - assim na arte de navegar, com o aparecimento dos navios a vapor e depois os movidos por combustíveis fósseis e por energia nuclear". Mas como ele mesmo mostra, não são produtos do trabalho humano separados. O próprio significado etimológico de tecnologia (conhecimento da técnica) os articula dialeticamente na unidade do diverso.

${ }^{16}$ Numa extensa obra sobre o conceito de tecnologia (dois volumes), Vieira Pinto (2005:520) também realça essa relação dialética. "O movimento da técnica no plano concreto obedece às leis gerais da dialética objetiva, respeitada a correlação recíproca entre o pensamento, onde a realidade se reflete, e a ação que nela se origina, para transformar esta mesma realidade".

${ }^{17}$ Como nos ateremos fundamentalmente ao que caracteriza o capitalismo no Brasil, mas não desligado do passado sem o qual o hoje não é entendido, uma leitura importante é a de Sodré (2004) sobre a formação histórica do Brasil.

${ }^{18}$ 'Título é inspirado no texto 'O ornitorrinco', in Francisco de Oliveira (2003:12-23).

${ }^{19} \mathrm{Em}$ termos gramscianos, nada mais falso do que a tese em voga, há algumas décadas no Brasil, da blindagem da economia da ação política. Trata-se, em verdade, de uma estratégia de tentar eliminar a massa que constitui a classe trabalhadora e seus intelectuais da ação política, reduzindo a política econômica do capital à única política. Oliveira (2003) indica que a moeda se metamorfoseou em moeda estatal e, atualmente, em moeda do Banco Central. Para ele, trata-se do mecanismo mais poderoso de universalização da violência de classe.

${ }^{20}$ Parte dessa análise foi desenvolvida com Maria Ciavatta e Marise Ramos numa coletânea publicada recentemente. Ver Frigotto, Ciavatta \& Ramos (2005b).

${ }^{21}$ Luiz Fiori (2002), num breve texto, apresenta três projetos societários que conviveram e lutaram entre si durante todo o século XX: o liberalismo econômico, o nacional desenvolvimentismo ou desenvolvimentismo conservador e o desenvolvimento eco- 
nômico nacional e popular. Para este autor, o liberalismo econômico foi o berço da estratégia econômica do governo Cardoso e continua sendo, de forma radicalizada, a política econômica do ministro Palocci, como demonstra este e outros críticos do governo Lula. Esse projeto sempre se contrapôs ao nacional desenvolvimentismo ou desenvolvimentismo conservador, presente na Constituinte de 1891 e nos anos 30, e também, mais enfaticamente, ao projeto de desenvolvimento econômico nacional e popular. Esta terceira alternativa nunca ocupou o poder estatal, nem comandou a política econômica de nenhum governo republicano, mas teve enorme presença no campo da luta ideológico-cultural e das mobilizações democráticas.

${ }^{22}$ Não cabe aqui um retrospecto do debate sobre a teoria da dependência, cujos pensadores mais representativos, em suas diferentes nuances, são Rui Mauro Marini, Teotônio dos Santos e Fernando Henrique Cardoso. Este último fez questão, ao aderir à nova ordem do capitalismo neoliberal, de dizer que se esqueçam suas idéias do passado. O horizonte teórico que assumimos situa-se no horizonte das análises de Florestan Fernandes, que sublinha a tese do 'capitalismo dependente', e das análises de Caio Prado Júnior e Francisco de Oliveira, que sinalizaremos a seguir.

${ }^{23}$ Trata-se, na verdade, de processos de democratização restritos, já que, como mostram Wood (2001, 2003) e Coutinho (2002), a democracia é incompatível com o capitalismo.

${ }^{24}$ Celso Furtado sintetiza sua visão crítica aos rumos das opções que o Brasil reiteradamente tem pautado dentro do seguinte dilema: a construção de uma sociedade ou de uma nação onde os seres humanos possam produzir dignamente a sua existência, ou a permanência em um projeto de sociedade que aprofunda sua dependência subordinada aos grandes interesses dos centros hegemônicos do capitalismo mundial. Em seus últimos escritos, destaca justamente a crítica ao monetarismo e a ótica do ajuste fiscal, mostrando que eles são responsáveis pelo truncamento de nosso processo histórico e de industrialização. Ver deste autor, especialmente, Furtado (1982, 2000).

${ }^{25}$ Dados apresentados por Carl Dahlman e Cláudio Frischtak, técnicos do Banco Mundial, em conferência no Fórum Nacional. O Globo, caderno Economia. Rio de Janeiro, 13.mai.2005. p.23.

${ }^{26}$ A manutenção da concepção de 'exames supletivos', embora a lei tenha incorporado o que o pensamento crítico da área conceitua como 'Educação de Jovens e Adultos', revela a mentalidade do atraso da classe dominante e seu não-compromisso com a construção de condições para o Brasil constituir-se numa sociedade democrática e em posição de romper com a dependência científico-técnica que o impede de ter relações internacionais com autonomia e soberania.

${ }^{27}$ Sobre as políticas da década de 1990, além das obras já mencionadas de Neves (2000, 2000a, 2000b), ver Neves (1997) e Frigotto \& Ciavatta (2003, 2005). Sobre a política de ensino superior e educação básica e técnica profissional do governo Lula, ver, respectivamente, Neves (2004) e Frigotto, Ciavatta \& Ramos (2005a). 
${ }^{28}$ Marilena Chauí, em recente entrevista, salienta: “Lula, infelizmente, não é um governo de esquerda. (...) Lula marcaria sua posição se dissesse: 'Eu vim em nome da classe trabalhadora, eu vim em nome dos movimentos sociais e populares, e é com eles que vou governar"”. (jornal Brasil de Fato, São Paulo, 24 a 30.nov.2005, p.6). Para um aprofundamento desse tema, ver Boito (2003), Frigotto (2004) e Oliveira (2004, 2005).

${ }^{29}$ No que se refere à produção dos intelectuais para a pedagogia da hegemonia, além das obras de Neves (2003, 2005), ver a análise de Gurgel (2003) sobre a formação nos cursos superiores, especialmente os de economia, engenharia, direito e administração. Trata-se, para este autor, de uma gerência do pensamento para a produção da consciência neoliberal. ${ }^{30}$ Céa (2003) efetua uma densa análise sobre o Planfor, definindo-o não primeiramente como política de formação e qualificação, mas sobretudo como política social, focalizada e precária, dentro da agenda da reforma do Estado e da reestruturação produtiva. Antoniozzi (2005), num detalhado trabalho empírico sobre o Planfor no estado da Bahia, diz que ele fracassou como política de emprego e de qualificação profissional do trabalhador.

${ }^{31}$ Para Castel, as políticas de 'integração social' têm como sua base fundamental, na 'idade de ouro do capitalismo’ (Hobsbawm, 1995), no contexto do Estado de bem-estar social, o emprego formal e os direitos que foram sendo conquistados pela classe trabalhadora. As políticas 'de inserção' expressam uma garantia precária em ocupações de baixa remuneração, sem garantias contratuais efetivas e, portanto, dos direitos conquistados pela classe trabalhadora, num contexto de mundialização do capital e desemprego estrutural. O que queremos realçar é que, se contraditoriamente a defesa do emprego formal e da garantia dos direitos conquistados pela classe trabalhadora é um ponto crucial na luta socialista, ainda mais numa sociedade como a brasileira, de parcos direitos do trabalhador, não é o seu objetivo central e final. Trata-se de uma luta no plano das contradições do sistema capital, mas cuja evidência histórica aqui demonstrada pelas análises de Marx, Gramsci, Harvey, Chesnais, Mészáros e Hobsbawm, entre outros, indica que não é da natureza desse sistema criar condições de pleno emprego. Ao contrário, na atual fase, sua tendência é incorporar cada vez menos trabalhadores e com um nível de exploração e alienação mais acentuados. Mais do que nunca se apresenta como pedagogia contra-hegemônica a tese da necessidade histórica do socialismo. Sem esse horizonte, a tese de Castel pode nos induzir puramente a um viés reformista ilusório.

${ }^{32}$ Uma análise que mostra aspectos importantes das experiências de educação integral da CUT é feita por Bárbara, Miyashiro e Garcia (2004).

${ }^{33} \mathrm{O}$ debate sobre a melhor denominação - educação politécnica ou tecnológica - tem a sua razão de ser, todavia, como salienta Saviani: "para além da questão terminológica, isto é, independentemente da preferência de denominação 'educação tecnológica' ou 'politécnica', é importante observar que, do ponto de vista conceitual, o que está em causa é o mesmo conteúdo. Trata-se da união entre formação intelectual e trabalho produtivo que, no texto do Manifesto, aparece como 'unificação da instrução com a produção material', nas Instru- 
ções como 'unificação politécnica que transmita os fundamentos científicos gerais de todos os processos de produção e n'O Capital, como 'instrução tecnológica teórica e prática”' (Saviani, 2003:145-146). Este autor entende que, pelo fato de que há um senso comum que reduz o tecnológico, em nossa formação histórica, ao tecnicista, talvez gerasse menos confusão o uso do termo 'educação politécnica'. Sem dúvida isso é pertinente, mas considerando que o tema da universidade tecnológica está na agenda do debate educacional, talvez seja igualmente pertinente um trabalho pedagógico de ressignificar a concepção de educação tecnológica.

${ }^{34}$ Trata-se do projeto cujo título é 'Educação Tecnológica e o Ensino Médio: concepções, sujeitos e a relação quantidade/qualidade', que vimos desenvolvendo no Programa Interdisciplinar de Pós-Graduação em Políticas Públicas e Formação Humana na Universidade do Estado do Rio de Janeiro (Uerj) - em articulação com outros projetos que têm interfaces com o tema - com Maria Ciavatta, Marise Ramos e Vera Corrêa e com apoio do CNPq e da Faperj (2005-2008).

${ }^{35}$ No momento em que o Brasil se propôs efetivar um amplo impulso no seu desenvolvimento urbano-industrial, a partir sobretudo da década de 1940, não só configurou-se o sistema nacional de educação como criou-se uma rede de escolas técnicas federais com o objetivo de formação do trabalho complexo. Trata-se de escolas que decisivamente não desenvolvem como opção teórica e política a concepção de educação escolar unitária e politécnica e/ou tecnológica; mas as condições objetivas de sua estrutura é a que melhor, no plano das contradições, poderia ensejar a disputa por uma educação unitária e politécnica. Não é por acaso que na década de 1990, com a clara opção de abandonar um projeto nacional de industrialização e de, portanto, amplo investimento em ciência e tecnologia e formação escolar para lhe dar sustentação, o Decreto 2.208/97 desarticula totalmente esse sistema para a formação no nível médio de ensino.

${ }^{36} \mathrm{O}$ leitor que queira ter os pontos básicos da análise que fazemos sobre essa 'opção', assim como das referências de várias análises que nos permitem aprofundar a compreensão desse golpe na esperança de mudanças estruturais, pode consultar o texto 'O Brasil e a política econômico-social: entre o medo e a esperança' (Frigotto, 2005a).

${ }^{37}$ A ênfase sistemática nesse aspecto crucial está pouco presente no debate da esquerda no Brasil nos campos educacional, político, sindical e dos movimentos sociais. Há, contudo, exceções na produção intelectual e nos movimentos sociais. Destacamos, no primeiro caso, as publicações que têm sido sistemáticas, na sua maior parte referidas neste texto, da autoria de ou coordenadas por Lúcia Neves a partir do Coletivo de Estudos sobre Política Educacional; e, no segundo, as formulações políticas e educacionais do Movimento dos Sem Terra. 


\section{REFERÊNCIAS BIBLIOGRÁFICAS}

ALGEBAILE, E. Escola Pública e Pobreza: os sentidos da expansão escolar na formação da escola pública brasileira, 2002. Tese de Doutorado, Niterói: Universidade Federal Fluminense.

ALTVATER, E. O Preço da Riqueza: pilhagem ambiental e a nova (des)ordem mundial. São Paulo: Unesp, 1995.

ANDERSON, P. A Crise da Crise do Marxismo. 2.ed. São Paulo: Brasiliense, 1985.

ANTONIOZZI, M. R. F. O Plano de Qualificação Profissional do Trabalhador: política pública de emprego? Salvador: UFBA, 2005.

ARRIGHI, G. A Ilusão do Desenvolvimento. Petrópolis: Vozes, 1998.

BÁRBARA, M. M.; MIYASHIRO, R. \& GARCIA, S. M. de O. Experiências de Educação Integral da CUT: práticas em construção. Rio de Janeiro: DP\&A, 2004.

BENSAID, D. Trabalho e emancipação. In: LOWY, M. \& BENSAID, D. Marxismo Modernidade Utopia. São Paulo: Xamã, 2000. p.85-100.

BOITO, A. A hegemonia neoliberal no governo Lula. Crítica Marxista, 17. São Paulo: Revan, 2003. p.10-36.

BOSI, A. Dialética da Colonização. São Paulo: Companhia das Letras, 1992.

BOTTOMORE, T. Dicionário do Pensamento Marxista. Rio de Janeiro: Zahar, 2001.

CANDIDO, A. A Revolução de 1930 e a cultura. Novos Estudos Cebrap, 2(4):2735. São Paulo, abr.1984.

CASTEL, R. As armadilhas da exclusão. In: BELFIORE-WANDERLEY, M.; BÓGUS, L. \& YAZBEK, M. C. (Orgs.). Desigualdades e a Questão Social. São Paulo: Educ, 1997. p.15-48.

CASTEL, R. As Metamorfoses da Questão Social: uma crônica do salário. Trad. Iraci D. Poleti. Rio de Janeiro: Vozes, 1998.

CÉA, G. S. dos S. A Qualificação Profissional entre Fios Invisiveis: uma análise crítica do Plano Nacional de Qualificação do Trabalhador, 2003. Tese de Doutorado, São Paulo: Pontifícia Universidade Católica.

CHESNAIS, F. A Mundialização do Capital. São Paulo: Xamã, 1996.

CHESNAIS, F. (Coord.). A Mundialização Financeira. São Paulo: Xamã, 1998.

COUTINHO, C. N. Contra a Corrente: ensaios sobre democracia e socialismo. São Paulo: Cortez, 2000.

COUTINHO, C. N. A democracia na batalha das idéias e nas lutas políticas do Brasil de hoje. In: FÁvero, O. \& SEMERARO, G. (Orgs.). Democracia e Construção do Público no Pensamento Educacional Brasileiro. Petrópolis: Vozes, 2002. 
ENGELS, F. Do Socialismo Utópico ao Socialismo Cientifico. Rio de Janeiro: Global, 1985.

EXAME, 30(15). São Paulo, 17 jul. 1996.

FERNANDES, F. Capitalismo Dependente e Classes Sociais na América Latina. Rio de Janeiro: Zahar, 1975.

FERNANDES, F. A Revolução Burguesa no Brasil: um ensaio de interpretação sociológica. 3.ed. Rio de Janeiro: Zahar, 1981. (Biblioteca de ciências sociais)

FERNANDES, F. Depoimentos. Série Memória Viva da Educação, v.1. Brasília: MECInep, 1991.

FIORI, J. L. O nome aos bois. São Paulo: Instituto da Cidadania/Fundação Perseu Abramo, 30.10.2002. (Mimeo.)

FORESTER, V. O Horror Econômico. São Paulo: Unesp, 1997.

FRIGOTTO, G. A Produtividade da Escola Improdutiva. São Paulo: Cortez: Autores Associados, 1984.

FRIGOTTO, G. Trabalho como princípio educativo: por uma superação das ambigüidades. Boletim Técnico do Senac, 11(3):175-192, set./dez.1985.

FRIGOTTO, G. A nova e a velha face da crise do capital e o labirinto dos referenciais teóricos. In: FRIGOTTTO, G. \& CIAVATTA, M. (Orgs.) Teoria e Educação no Labirinto do Capital. 2.ed. Petrópolis: Vozes, 2002. p.23-50.

FRIGOTTO, G. O Brasil e a política econômico-social: entre o medo e a esperança. Observatório Social de América Latina. Clacso, 14:95-104, maio-ago.2005a.

FRIGOTTO, G. Escola pública da atualidade: lições da história. In: LOMBARDI, J. C. Escola Pública no Brasil. Campinas: Editores Associados, 2005b.

FRIGOTTO, G. \& CIAVATTTA, M. Educar o trabalhador cidadão produtivo ou o ser humano emancipado? Trabalho, Educação e Saúde, 1(1):45-60, 2003.

FrigotTO, G. \& CIAVATTA, M. (Orgs.) A Formação do Cidadão Produtivo: a cultura do mercado no ensino médio técnico. Brasília: Inep/MEC, 2005.

FRIGOTTO, G.; CIAVATTAA, M. \& RAMOS, M. A política de educação profissional no Governo Lula: um percurso histórico controvertido. Educação e Sociedade, 26(92):1.087-1.113, out. 2005a.

FRIGOTTO, G.; CIAVATTA, M. \& RAMOS, M. (Orgs.) Ensino Médio Integrado: concepção e contradições. São Paulo: Cortez, 2005b.

FrigotTo, G.; CiAVATTA, M. \& RAMOs, M. Educação Profissional e Desenvolvimento. Berlim: Centro Interamericano de Educação/Unesco, 2006 (no prelo).

FURTADO, C. Análise do 'modelo' brasileiro. Rio de Janeiro: Civilização Brasileira, 1982. 
FURTADO, C. Introdução ao Desenvolvimento: enfoque histórico-estrutural. São Paulo: Paz e Terra, 2000.

GRAMSCI, A. Americanismo e fordismo. In: GRAMSCI, A. Maquiavel, a Política e o Estado Moderno. Rio de Janeiro: Civilização Brasileira, 1976. p.375-413.

GRAMSCI, A. Os Intelectuais e a Organiz̧ação da Cultura. Rio de Janeiro: Civilização Brasileira, 1979.

GRAMSCI, A. Cadernos do Cárcere. v.3. Ed. e trad. de Carlos Nelson Coutinho. Rio de Janeiro: Civilização Brasileira, 2000.

GURGEL, C. A Gerência do Pensamento: gestão contemporânea e consciência neoliberal. São Paulo: Cortez, 2003.

HARVEY, D. A Condição Pós-Moderna. São Paulo: Loyola, 1998.

HARVEY, D. O Novo Imperialismo. São Paulo: Loyola, 2005.

HOBSBAWM, E. Adeus a tudo aquilo. In: BLACKBURN, R. (Org.) Depois da Queda: o fracasso do comunismo e o futuro do socialismo. Rio de Janeiro: Paz e Terra, 1992a. p.93-106.

HOBSBAWM, E. Renascendo das cinzas. In: BLACKBURN, R. (Org.) Depois da Queda: o fracasso do comunismo e o futuro do socialismo. Rio de Janeiro: Paz e Terra, 1992b. p.255-270.

HOBSBAWM, E. A Era dos Extremos: o breve século XX (1914-1991). São Paulo: Companhia das Letras, 1995.

HOBSBAWM, E. O Novo Século. Entrevista a Antônio Polito. São Paulo: Companhia das Letras, 2000.

JAMESON, F. Pós-Modernismo: a lógica cultural do capitalismo tardio. São Paulo: Ática, 1996.

JAMESON, F. As Sementes do Tempo. São Paulo: Ática, 1997.

JAMESON, F. A Cultura do Dinheiro: ensaios sobre a globalização. Petrópolis: Vozes, 2001.

KOSIK, K. Dialética do Concreto. Rio de Janeiro: Paz e Terra, 1986.

LUKÁCS, G. As bases ontológicas do pensamento e da atividade do homem. Temas de Ciências Humanas, 4:1-18, 1978.

MANACORDA, M. O Princípio Educativo em Gramsci. Porto Alegre: Artes Médicas, 1990.

MARX, K. Manuscritos de Economia y Filosofía. Madri: Alianza, 1972.

MARX, K. Grundrisse (1857-1858): introducion to critique of political economy. Trad. Martin Nicolaus. Nova York: Vintage Books, 1973.

MARX, K. O Capital. São Paulo: Abril Cultural, 1983.

MÉSZÁROS, I. Marx e a Teoria da Alienação. Rio de Janeiro: Zahar Editores, 1981. 
MÉSZÁROS, I. Para Além do Capital. Campinas: Boitempo, 2002.

MODERnO, J. R C. O Pensamento de Mao Tsé Tung. Rio de Janeiro: Paz e Terra, 1979.

NEVES, L. M. W. Política Educacional dos Anos 90: determinantes e propostas. 2.ed. Recife: Editora Universitária da UFPE, 1997.

NEVES, L. M. W. (Org.). Educação e Politica no Limiar do Século XXI. Campinas: Autores Associados, 2000.

NEVES, L. M. W. (Org.). O Empresariamento da Educação: novos contornos do ensino superior no Brasil nos anos 1990. São Paulo: Xamã, 2002a.

NEVES, L. M. W. As massas trabalhadoras começam a participar do banquete, mas o cardápio é escolhido à sua revelia, ou democracia e educação escolar nos anos iniciais do século XXI. In: FÁVERO, O. \& SEMERARO, G. (Orgs.) Democracia e Construção do Público no Pensamento Educacional Brasileiro. Petrópolis: Vozes, 2002b.

NEVES, L. M. W. Brasil Ano 2000: uma nova divisão do trabalho na educaşão. 2.ed. São Paulo: Xamã, 2003.

NEVES, L. M. W. A Reforma Universitária do Governo Lula: reflexões para o debate. São Paulo: Xamã, 2004.

NEVES, L. M. W. (Org.). A Nova Pedagogia da Hegemonia: estratégias do capital para educar o consenso. São Paulo: Xamã, 2005.

OLIVEIRA, F. de. A Economia Brasileira: crítica à razão dualista. Petrópolis: Vozes, Cebrap, 1972.

OLIVEIRA, F. de. A vanguarda do atraso e o atraso da vanguarda. In: OLIVEIRA, F. de. Os Direitos do Antivalor: a economia politica da hegemonia imperfeita. Petrópolis: Vozes, 1998. p.205-221.

OLIVEIRA, F. de. Crítica à Razaão Dualista: o ornitorrinco. São Paulo: Boitempo, 2003.

OLIVEIRA, F. de. Hay vias abiertas para América Latina? In: BORON, A. (Comp.). Nueva Hegemonía Mundial: alternativas de cambio y movimientos sociales. Buenos Aires: Clacso, 2004.

OLIVEIRA, F. de. Em busca do consenso perdido: democratização e republicanização do Estado. In: AUED, B. W. (Org.). Traços do Trabalho Coletivo. São Paulo: Casa do Psicólogo, 2005.

PAIVA, V. \& GIANOTTI, J. A. Contradição entre o fundamento da produção burguesa (medida-valor) e seu próprio desenvolvimento: máquinas etc. Revista Contemporaneidade e Educação, ano 5, 7:150-153, $1^{\circ}$ sem. 2000.

PARIS, C. O Animal Cultural. São Carlos: Editora da UFSCAr, 2002.

PISTRAK, M. M. Fundamentos da Escola do Trabalho. São Paulo: Brasiliense, 1981. 
POCHMANN, M. O flagelo dos jovens trabalhadores. Folha de S.Paulo, São Paulo, 22.fev.1998, Folha Dinheiro, p.2.

POCHMANN, M. O Trabalho sob o Fogo Cruzado: desemprego e precarização no final do século. São Paulo: Contexto, 1999.

POCHMANN, M. As duas rendas mínimas. Jornal do Brasil. Rio de Janeiro, 22.mai.2004, Outras Opiniões, p.9.

PRADO JR., C. A Revolução Brasileira. São Paulo: Brasiliense, 1966.

RAMOS, M. N. A Pedagogia das Competências: autonomia on adaptação? São Paulo: Cortez, 2001.

RODRIGUES, J. O Moderno Príncipe Industrial: o pensamento pedagógico da Confederação Nacional da Indústria. Campinas: Autores Associados, 1998.

SANTOS, B. de S. Reinventando a democracia: entre o pré-contratualismo e o pós-contratualismo. In: HELLER, A. et al. A Crise dos Paradigmas em Ciências Sociais e os Desafios para o Século XXI. Rio de Janeiro: Contraponto, CoreconRJ, 1999.

SAVIANI, D Contribuição à elaboração da nova LDB: um início de conversa. Revista da ANDE, 13:5-14, 1988.

SAVIANI, D. O trabalho como princípio educativo frente às novas tecnologias. In: FERRETI, C. et al. (Orgs.). Novas Tecnologias, Trabalho e Educaşão: um debate interdisciplinar. Petrópolis: Vozes, 1994. p.147-164.

SAVIANI, D. O choque teórico da politecnia. Trabalho, Educação e Saúde, 1(1):131152, 2003.

SENNETT, R. A Corrosão do Caráter: conseqüências pessoais do trabalho no novo capitalismo. Trad. Marcos Santarrita. Rio de Janeiro: Record, 1999.

SILVA, T. T. (Org.) Trabalho, Educação e Prática Social: por uma teoria da formação bumana. Porto Alegre: Artes Médicas, 1992.

SODRÉ, N. W. Formação Histórica do Brasil. Rio de Janeiro: Graphia, 2004.

SOUZA, J. dos S. Trabalho, Educação e Sindicalismo no Brasil: anos 90. Campinas: Autores Associados, 2002.

VÁZQUEZ, A. S. A Tiempo y Destiempo. México: Fondo de Cultura Económica, 2003.

VIEIRA PINTO, A. O Conceito de Tecnologia. 2v. Rio de Janeiro: Contraponto, 2005.

WOOD, E. M. A Origem do Capitalismo. Rio de Janeiro: Jorge Zahar Editor, 2001.

WOOD, E. M. Democracia contra Capitalismo: a renovação do materialismo histórico. Trad. Paulo César Castanheira. São Paulo: Boitempo, 2003. 


\title{
8. Fundamentos Ético-Políticos da Educação no Brasil de Hoje
}

Antônio Joaquim Severino

\begin{abstract}
A educação é processo inerente à vida dos seres humanos, intrínseco à condição da espécie, uma vez que a reprodução dos seus integrantes não envolve apenas uma memória genética mas, com igual intensidade, pressupõe uma memória cultural, em decorrência do que cada novo membro do grupo precisa recuperá-la, inserindo-se no fluxo de sua cultura. Ao longo da constituição histórico-antropológica da espécie, esse processo de inserção foi se dando, inicialmente, de forma quase que instintiva, prevalecendo o processo de imitação dos indivíduos adultos pelos indivíduos jovens, nos mais diferentes contextos pessoais e grupais que tecem a malha da existência humana. Porém, com a 'complexificação' da vida social, foram implementadas práticas sistemáticas e intencionais destinadas a cuidar especificamente desse processo, instaurando-se então instituições especializadas encarregadas de atuar de modo formal e explícito na inserção dos novos membros no tecido sociocultural. Nasceram então as escolas.

Sem prejuízo dos esforços e investimentos sistemáticos que ocorrem no seio de suas práticas formais, o processo abrangente de educação informal continua presente e atuante no âmbito da vida social em geral, graças às atividades interativas da convivência humana. Mas a formalização cada vez maior da interação educativa decorre da própria natureza da atividade humana, que é sempre intencionalmente planejada, sempre vinculada a um télos que a direciona. Desse modo, todos os agrupamentos sociais, quanto mais se tornaram complexos, mais desenvolveram práticas formais de educação, institucionalizando-as sistematicamente.
\end{abstract}


Desde sua gênese mais arcaica, essa inserção sociocultural envolve sempre uma significação valorativa, ainda que o mais das vezes implícita nos padrões comportamentais do grupo e inconsciente para os indivíduos envolvidos, pois se trata de um compartilhamento subjetivamente vivenciado de sentidos e valores. A cultura, como conjunto de signos objetivados, só é apropriada mediante um intenso processo de subjetivação.

O existir histórico dos homens realiza-se objetivamente nas circunstâncias dadas pelo mundo material (a natureza física) e pelo mundo social (a sociedade e a cultura) como referências externas de sua vida. No entanto, essa condição objetiva de seu existir concreto está intimamente articulada à vivência subjetiva, esfera constituída de diferentes e complexas expressões de seus sentimentos, sensibilidades, consciência, memória, imaginação. Esses processos põem em cena a intervenção subjetiva dos homens no fluxo de suas práticas reais, marcando-as intensamente. Mas, ao mesmo tempo, as referências objetivas condicionantes da existência atuam fortemente na gestação, na formação e na configuração dessa vivência. Daí falar-se do processo de subjetivação, modo pelo qual as pessoas constituem e vivenciam sua própria subjetividade. A percepção dos valores integra esse processo tanto quanto a intelecção lógica dos conceitos. Esse processo de subjetivação é que permite aos homens atribuir significações aos dados e situações de sua experiência do real, o que eles fazem sempre de forma plurivalente, pois essa atribuição de significações não leva a sentidos unívocos, porém, o mais das vezes, plurais e mesmo equívocos.

A discussão dos fundamentos ético-políticos da educação, objeto desta reflexão, envolve necessariamente a esfera da subjetivação, uma vez que implica referência a valores. Para conduzir essa discussão, o presente ensaio, elaborado de uma perspectiva filosófico-educacional, foi desenvolvido em três movimentos, cada um deles se desdobrando em dois percursos. O primeiro movimento, de caráter antropológico, procura, no primeiro percurso, situar a educação como prática humana, mediada e mediadora do agir histórico dos homens; e, no segundo, fundamentar teoricamente a necessária intencionalidade ético-política dessa prática, explicitando a sua relação com o processo de subjetivação. No segundo movimento, de cunho histórico, busca-se no primeiro momento mostrar como a experiência socioeducacional brasileira marcou-se por diversas subjetivações ideológicas, enquanto no segundo são destacados, por sua relevância, os desafios e dilemas da educação brasileira atual no contexto da sociabilidade neoliberal. No terceiro movimento, que tem uma perspectiva político- 
pedagógica, ressalta-se, inicialmente, o compromisso ético-político da educação como mediação da cidadania, para enfatizar, em seguida, a importância que a escola pública ainda tem como espaço público privilegiado para um projeto de educação emancipatória.

\section{A Educação como Prática Histórico-Social}

Falar de fundamentos éticos e políticos da educação pressupõe assumila na sua condição de prática humana de caráter interventivo, ou seja, prática marcada por uma intenção interventiva, intencionando mudar situações individuais ou sociais previamente dadas. Implica uma eficácia construtiva e realiza-se numa necessária historicidade e num contexto social. Tal prática é constituída de ações mediante as quais os agentes pretendem atingir determinados fins relacionados com eles próprios, ações que visam provocar transformações nas pessoas e na sociedade, ações marcadas por finalidades buscadas intencionalmente. Pouco importa que essas finalidades sejam eivadas de ilusões, de ideologias ou de alienações de todo tipo: de qualquer maneira são ações intencionalizadas das quais a mera descrição objetivada obtida mediante os métodos positivos de pesquisa não consegue dar conta da integralidade de sua significação. O lado visível do agir educacional dos homens fica profundamente marcado por essa construtividade e historicidade da prática humana e, como tal, escapa da normatividade nomotética e de qualquer outra forma de necessidade, seja ela lógica, seja biológica, física ou mesmo social, se tomado este último aspecto como elemento de pura objetividade. Os fenômenos de natureza política e educacional não se determinam por pura mecanicidade, ou melhor, só a posteriori ganham objetividade mecânica, transitiva, mas, a essa altura, já perderam sua significação especificamente humana. É que eles se dão num fluxo de construtividade histórica, construção esta referenciada a intenções e finalidades que comprometem toda a logicidade nomotética de seu eventual conhecimento.

O caráter práxico da educação, ou seja, sua condição de prática intencionalizada, faz com que ela fique vinculada a significações que não são da ordem da fenomenalidade empírica dessa existência e que devem ser levadas em conta em qualquer análise que se pretenda fazer dela, exigindo diferenciações epistemológicas que interferem em seu perfil cognoscitivo. Educação é prática histórico-social, cujo norteamento não se fará de maneira técnica, con- 
forme ocorre nas esferas da manipulação do mundo natural, como, por exemplo, naquelas da engenharia e da medicina.

No seu relacionamento com o universo simbólico da existência humana, a prática educativa revela-se, em sua essencialidade, como modalidade técnica e política de expressão desse universo, e como investimento formativo em todas as outras modalidades de práticas. Como modalidade de trabalho, atividade técnica, essa prática é estritamente cultural, uma vez que se realiza mediante o uso de ferramentas simbólicas. Desse modo, é como prática cultural que a educação se faz mediadora da prática produtiva e da prática política, ao mesmo tempo que responde também pela produção cultural. É servindo-se de seus elementos de subjetividade que a prática educativa prepara para o mundo do trabalho e para a vida social (Severino, 2001). Os recursos simbólicos de que se serve, em sua condição de prática cultural, são aqueles constituídos pelo próprio exercício da subjetividade, em seu sentido mais abrangente, sob duas modalidades mais destacadas: a produção de conceitos e a vivência de valores. Conceitos e valores são as referências básicas para a intencionalização do agir humano, em toda a sua abrangência. O conhecimento é a ferramenta fundamental de que o homem dispõe para dar referências à condução de sua existência histórica. Tais referências se fazem necessárias para a prática produtiva, para a política e mesmo para a prática cultural.

Ser eminentemente prático, o homem tem sua existência definida como um contínuo devir histórico, ao longo do qual vai construindo seu modo de ser, mediante sua prática. Essa prática coloca-o em relação com a natureza, mediante as atividades do trabalho; em relação com seus semelhantes, mediante os processos de sociabilidade; em relação com sua própria subjetividade, mediante sua vivência da cultura simbólica. Mas a prática dos homens não é uma prática mecânica, transitiva, como o é a dos demais seres naturais; ela é uma prática intencionalizada, marcada que é por um sentido, vinculado a objetivos e fins, historicamente apresentados.

Além disso, a intencionalização de suas práticas também se faz pela sensibilidade valorativa da subjetividade. O agir humano implica, além de sua referência cognoscitiva, uma referência valorativa. Com efeito, a intencionalização da prática histórica dos homens depende de um processo de significação simultaneamente epistêmico e axiológico. Daí a imprescindibilidade das referências éticas do agir e da explicitação do relacionamento entre ética e educação. 


\section{A Prática Educacional como Prática ÉTICO-POLÍTICA}

Na esfera da subjetividade, a vivência moral é uma experiência comum a todos nós. Pelo que cada um pode observar em si mesmo e pelo que se pode constatar pelas mais diversificadas formas de pesquisas científicas e de observações culturais, todos os homens dispõem de uma sensibilidade moral, mediante a qual avaliam suas ações, caracterizando-as por um índice valorativo, o que se expressa comumente ao serem consideradas como boas ou más, lícitas ou ilícitas, corretas ou incorretas. Hoje se sabe, graças às contribuições das diversas ciências do campo antropológico, que muitos dos padrões que marcam o nosso agir derivam de imposições de natureza sociocultural, ou seja, os próprios homens, vivendo em sociedade, acabam impondo uns aos outros determinadas normas de comportamento e de ação. Mas a incorporação dessas normas pressupõe uma espécie de adesão por parte das pessoas individualmente, ou seja, é preciso que elas vivenciem, no plano de sua subjetividade, a força do valor que lhe é, então, imposto. Os usos, os costumes, as práticas, os comportamentos, as atitudes que carregam consigo essas características e que configuram $\mathrm{o}$ agir dos homens nas mais diferentes culturas e sociedades constituem a moral. A moralidade é fundamentalmente a qualificação desses comportamentos, aquela 'força' que faz com que eles sejam praticados pelos homens em função dos valores que essa qualificação subsume. Podemos constatar que é em função desses valores que as várias culturas, nos vários momentos históricos, vão constituindo seus códigos morais de ação, impondo aos seus integrantes um modo de agir que esteja de acordo com essas normas. Porém, por mais que se encontre premido por essas normas, o homem defronta-se com a experiência insuperável de que participa pessoalmente da decisão que o leva a agir dessa ou daquela maneira; sente-se responsável por sua ação e muitas vezes bem ciente das conseqüências dela. Assim, a norma moral tem um caráter imperativo que o impressiona. Os valores morais impõem-se ao homem com força normativa e prescritiva, quase que ditando como e quando suas ações devem ser conduzidas. Quando não as segue, tem a impressão de estar fazendo o que não devia fazer, embora continue com um nível proporcional de liberdade para não fazer como e quando a norma parece lhe impor.

Se toda e qualquer ação do homem dependesse deterministicamente de fatores alheios à sua vontade livre, então não seria o caso de se sentir responsá- 
vel por elas; mas ocorre que, apesar de toda a gama de condicionamentos que o cercam e o determinam, há margem para a intervenção de uma avaliação de sua parte e para uma determinada tomada de posição e de decisão. Goza, por isso, de um determinado campo de liberdade, de vontade livre, de autonomia, não podendo alegar total determinação por fatores externos à sua decisão.

Hoje, os conhecimentos objetivos da realidade humana, proporcionados pelas ciências humanas, de modo especial a psicologia, a sociologia, a economia, a etologia, a psicanálise, a antropologia e a história, permitem identificar com bastante precisão aquelas atitudes que são tomadas por imposição de forças superiores à vontade pessoal. Mas permitem ver igualmente mais claro o alcance da vontade e o nível de arbítrio de que se dispõe quando se tem de escolher entre várias alternativas, assim como a possibilidade de saber qual a 'melhor' opção cabe em cada caso. Pode-se falar então da consciência moral, fonte de sensibilidade aos valores que norteiam o agir humano, análoga à consciência epistêmica, que permite ao homem o acesso à representação dos objetos de sua experiência geral, mediante a formação de conceitos. Assim, como tem uma consciência sensível aos conceitos, tem igualmente uma consciência sensível aos valores.

Do mesmo modo que a filosofia sempre se preocupou em discutir e buscar compreender como se formam os conceitos, como se pode acessá-los, o que os funda, ela procura igualmente compreender como se justifica essa sensibilidade aos valores. Desenvolveu então uma área específica de seu campo de investigação, no âmbito da axiologia, para conduzir essa discussão: a ética.

Cabe aqui um breve esclarecimento semântico. Moral e ética não são propriamente dois termos sinônimos, apesar da etimologia análoga, em latim e em grego, respectivamente. É certo que, na linguagem comum do dia-a-dia, já não se distingue um conceito do outro. Mas, a rigor, moral refere-se à relação das ações com os valores que a fundam, tais como consolidados num determinado grupo social, não exigindo uma justificativa desses valores que vá além da consagração coletiva em função dos interesses imediatos desse grupo. No caso da ética, refere-se a essa relação, mas sempre precedida de um investimento elucidativo dos fundamentos, das justificativas desses valores, independentemente de sua aprovação ou não por qualquer grupo. Por isso, fala-se de ética em dois sentidos correlatos: de um lado, frisa-se a sensibilidade aos valores justificados mediante uma busca reflexiva por parte dos sujeitos; de outro, convencionou-se chamar igualmente de ética a disciplina filosófica que busca elucidar esses fundamentos. 
Mas de onde vem o valor dos valores? Onde se funda a consciência moral? Se o homem é um ser histórico em construção, em devir, sem vinculação determinante com a essência metafísica e a natureza física, naquilo que lhe é específico, onde ancorar a referência valorativa de sua consciência moral? $O$ valor fundador dos valores que fundam a moralidade é aquele representado pela própria dignidade da pessoa humana, ou seja, os valores éticos fundam-se no valor da existência humana. É em função da qualidade desse existir, delineado pelas características que lhe são próprias, que se pode traçar o quadro da referência valorativa, para se definir o sentido do agir humano, individual ou coletivo. O próprio homem já é um valor em si, nas suas condições contingenciais de existência, na sua radical historicidade, facticidade, corporeidade, incompletude e finitude.

Assim, a filosofia, por meio da ética, busca dar conta dos possíveis fundamentos desse nosso modo de 'vivenciar' as coisas, tendo sempre em vista que é necessário ir além das justificativas imediatistas, espontaneístas e particularistas das morais empíricas de cada grupo social. A ética coloca-se numa perspectiva de universalidade, enquanto a moral fica sempre presa à particularidade dos grupos e mesmo dos indivíduos. Mas é possível encontrar um fundamento universal para os valores éticos? A filosofia ocidental, como mostra sua história milenar, sempre o procurou e continua a procurá-lo, dada a permanência das demandas da consciência ética.

\section{A EducaçÃo BrasileIRA: DETERMINAÇÃo hISTÓRICA E SUBJETIVAÇÃO VALORATIVA}

A presença da educação formal e institucionalizada é traço marcante das sociedades ocidentais, com destaque para a sociedade européia. No caso do Brasil, em que pese sua ainda pequena trajetória na era moderna da sociedade ocidental e a lentidão de seu desenvolvimento nos três primeiros séculos de sua inserção histórica nessa sociedade, ela não ocorreu de forma diferente. O Brasil conta com uma já bastante visível experiência de educação formal, experiência esta herdeira da experiência européia, forjada sob a marca da perspectiva cristã, mas tributária igualmente das circunstâncias históricas próprias do contexto local.

Instaurada então nos idos da fase colonial sob a concepção escolástica da formação humana, a educação no Brasil nasce como obra do trabalho missionário dos jesuítas, fundada sob uma perspectiva ideológica católica, de origem 
na Contra-Reforma, e operacionalizada pedagogicamente sob o modelo da escolástica. Em que pese a pequena expressão de um aparelho escolar nesse período, a cultura brasileira dos períodos colonial e imperial foi impregnada pelo catolicismo. Com seus conceitos e valores, o catolicismo marcou a vida social e cultural do país, contribuindo significativamente para um forte processo de subjetivação de seus habitantes, sob a representação dos dogmas doutrinários católicos.

No que concerne às relações entre a educação e a ideologia católica, fundada, de um lado, na teologia cristã e, de outro, na metafísica da escolástica tomista, prevalece a postulação de uma ética essencialista, articulada ao voluntarismo moral. A dimensão política não tem autonomia como dinâmica de pulsão de valores propriamente sociais. Toda a defesa dos valores cristãos é baseada na crença do poder da vontade individual para a condução da vida, uma vez que da postura ética de todas as pessoas decorreria necessariamente uma vida coletiva harmoniosa, independentemente das condições contextuais, da hierarquização das pessoas e da arbitrariedade das ações dos mais fortes. Não sem razão, durante todo esse longo período de Colônia e Império, a evolução do sistema educacional do país, tanto do ponto de vista organizacional como do ponto de vista de sua função social, foi pouco significativa, uma vez que a finalidade da escola encontrava-se na continuidade da finalidade evangelizadora e pastoral da Igreja, não se podendo falar de referências políticas para a configuração da ética. Visava-se a uma ética fundada na vontade individual das pessoas, o que podia se realizar preferencialmente na esfera privada, não se atribuindo à educação a contribuição para a instauração de um espaço público de vida. Desse modo, o pouco que houve de institucionalização de educação escolar serviu de reforço para a reprodução da ideologia dominante e das condições econômico-sociais, marcadas pela degradação, pela opressão e pela alienação da maioria da população em relação às situações de trabalho, de participação política e de vivência cultural. O modelo econômico era o agrárioexportador, voltado para a produção agrícola destinada à exportação aos países centrais. Todo o aparato político da época visava dar sustentação aos segmentos dominantes, que, além de possuírem os meios de produção e até a força de trabalho (detinham a posse da terra, a força escrava, a renda financeira), utilizavam o controle ideológico pela divulgação e 'inculcação' da concepção cristã do mundo. Assim, ao lado da alienação objetiva em que as pessoas se encontravam lançadas pelas condições socioeconômicas, ocorria o reforço de 
uma percepção enviesada dessas condições pela consciência, que instaura então uma alienação subjetiva. Coube ao ideário católico exercer esse papel, funcionando então como ideologia adequada ao momento histórico.

Pode-se afirmar que o cristianismo, a par de seus princípios teológicos, apresentava igualmente uma ética individual, da qual decorreram as referências também para o convívio social, dada a suprema prioridade da pessoa sobre a sociedade. É a qualidade moral dos indivíduos que devia garantir a qualidade moral da sociedade. Mas o caráter idealizado dessas referências comprometia sua eficácia histórica, pois esta dependeria da causalidade da vontade, insuficiente para mover a realidade social. Daí transformar-se numa ideologia, atuando apenas como ideologia. É o que explica sua incapacidade de impedir a prática da escravidão, apesar de, no plano teórico, tratar-se de prática incompatível com os valores apregoados.

Mas a ideologia católica dos primeiros séculos de formação da sociedade brasileira foi perdendo aos poucos sua hegemonia em decorrência da mudança socioeconômica pela qual o país igualmente sofreu em decorrência da lenta, extensa e intensa expansão do capitalismo. Embora a imersão do Brasil no capitalismo não tivesse ocorrido com características idênticas ao que havia acontecido na Europa e na América do Norte, não se podendo nem mesmo falar de uma revolução burguesa que o implantasse em nossas paragens, o país não podia escapar à influência dessa expansão comandada inicialmente pelos ingleses e, posteriormente, pelos americanos. Assim, a sociedade brasileira, embora conservando muitos elementos de sua fase escravista, incorporou as forças produtivas do modo de produção capitalista e as conseqüentes configurações no plano político e cultural. Da mesma forma, novos valores passaram a marcar a subjetividade das pessoas, dando nova fisionomia à vida da sociedade. Com o capitalismo, a oligarquia rural e o campesinato perderam poder social, emergindo uma burguesia urbano-industrial, as camadas médias e o proletariado, que se tornaram os novos sujeitos a conduzir a vida nacional, impondo alterações significativas no perfil da vida político-social do país. Em que pesem suas reconhecidas limitações, o processo republicano espelhou essa nova realidade, ligando-se a novas referências ideológicas, decorrentes de outros paradigmas filosóficos, como o iluminismo, o liberalismo, o laicismo, o positivismo (Severino, 1986).

A nova ideologia que se configurou entrou em conflito com a ideologia conservadora do catolicismo, embora se trate de conflito que não chegou a 
gerar uma ruptura radical na coesão da sociedade, em função das peculiaridades da própria configuração das classes sociais do país. A Revolução de 1930 é um marco representativo desse novo momento vivido pela sociedade brasileira, referendando-o e dando-lhe maior identidade. O processo se consolidou com o fim da Segunda Guerra Mundial, quando o capitalismo, sob a égide americana, se instalou de forma irreversível. Com a Revolução de 1964, esse ciclo se completou, mediante uma estruturação tecnocrática, inserindo de vez a economia do país no fluxo do capitalismo mundial.

Essa modernização econômica e cultural do país levou à paulatina substituição da ideologia religiosa do catolicismo por uma ideologia laica, de inspiração liberal e republicana. Nesse novo ambiente de desenvolvimentismo e modernização, a educação institucionalizada teve seu papel extremamente revalorizado, uma vez que lhe cabiam então tarefas importantes não só na formação cultural das pessoas mas também na profissionalização dos trabalhadores para as indústrias e para os diversos serviços. Além disso, as camadas médias viam na educação um dos principais caminhos para a ascensão social, o que suscitou forte demanda pela educação. Esta deveria ser fornecida por um sistema público, laico, imune às interferências de cunho religioso. À educação cabia então cuidar da preparação de mão-de-obra para a expansão industrial e dos serviços, bem como da oferta de cultura e status social. Este passava a ser o perfil do novo cidadão, imbuído de espírito público e identificado com a construção de sua pátria nacional.

Todo o complexo conjunto de valores, de forte inspiração iluminista e liberal, passou a ganhar contornos específicos, constituindo uma nova hegemonia ideológica. O modelo academicista, literário e humanístico da educação cristã foi considerado alienado em relação aos problemas sociais do país e não tinha condições de superar os desafios do atraso nacional. Só um humanismo lastreado no conhecimento científico e expresso mediante valores liberais poderia levar o país a seu verdadeiro destino. E a educação pública era o grande instrumento de que dispunha a sociedade para alcançar esse objetivo. Pública, laica, obrigatória e gratuita, a nova educação, nascida no bojo de uma reconstrução educacional, seria a única via para a reconstrução social. São apregoados os valores ligados ao espírito científico, à ordem democrática, às metodologias renovadas de ensino, à esfera pública, à cidadania e ao desenvolvimento econômico e social do país.

Mas esse novo projeto encontrou dois obstáculos insuperáveis que fizeram com que esses novos valores continuassem sendo apenas valores ideológi- 
cos. De um lado, a ideologia religiosa do catolicismo, embora não mais hegemônica no plano oficial, continuou impregnando, capilarmente, a vida cultural brasileira, da qual constitui, na verdade, uma camada arcaica da subjetivação das massas, arraigada que era no espírito do povo - e, como tal, impôs resistência à recepção das novas referências. Por isso, o impacto da nova ideologia, do lado da subjetivação, foi muito lento e superficial. De outro lado, o modo de produção capitalista tem suas exigências férreas, suas cláusulas pétreas, e não atua nos termos dos valores que apregoa. As políticas educacionais e culturais efetivamente implementadas não foram necessariamente coerentes, em seu caráter radical, com os valores declarados. Com isso, não se nega o efetivo desenvolvimento ocorrido no país, mas ele não aconteceu por força da realização dos novos valores; ao contrário, ocorreu muito mais pela violência das determinações do capitalismo em sua incansável busca da acumulação, com sensibilidade mínima às necessidades objetivas da maioria da população.

De qualquer modo, é correto afirmar que a ideologia que prevaleceu como elemento aglutinador da constituição da subjetividade social brasileira desse segundo período da trajetória sociopolítico-educacional do país foi a ideologia liberal burguesa, laicizada, modernizada e modernizadora, com pretensão de ser fundada na ciência e no reconhecimento da liberdade e da igualdade humanas. Impôs-se assim uma concepção liberal do mundo, da cultura e da educação. Essa ideologia atendia aos interesses da burguesia nacional urbanoindustrial e justificava a modernização de todos os setores da vida social. $\mathrm{Na}$ verdade, estava lançando raízes para um projeto que deveria consolidar cada vez mais o capitalismo monopolista, a serviço do qual deveria ser colocado o próprio Estado (Bresser Pereira, 1968; Fernandes, 1975).

No entanto, assim como a ideologia católica, a ideologia liberal não conseguiu implementar uma educação efetivamente voltada para a emancipação de toda a população, como pressupunha o ideário republicano, liberal e iluminista, limitando-se a exercer apenas seu papel ideológico, ou seja, proclamar, como se fossem universais, valores que são realizados apenas para atender a interesses particulares de grupos privilegiados. Enquanto as camadas dominantes mantiveram e ampliaram seus privilégios e as camadas médias usufruíram de algumas conquistas, vendo atendidas algumas de suas reivindicações, graças a seu poder de negociação e de aliança, os segmentos populares alcançaram objetivamente poucas conquistas econômicas, sociais e culturais, aí incluída a educação, que sequer se universalizou em seus níveis iniciais. 
Apesar de o atendimento das necessidades do povo fazer parte explícita do discurso político oficial, como se fosse o objetivo primordial das políticas públicas, na realidade, no tecido socioeconômico, não ocorreram mudanças significativas, nem quanto à quantidade nem quanto à qualidade. É o que mostram a injusta distribuição não só da renda como também dos bens culturais e os índices da desigualdade social, que permanecem até hoje (IBGE, 2005).

Agregou-se a essa ideologia liberal a crença no caráter redentor e equalizador da educação, que, se fosse difundido universalmente, eliminaria os conflitos de classe, promoveria o progresso econômico e social e asseguraria a condição de cidadania a todas as pessoas (Xavier, 2005).

Com o regime militar autoritário que se estabelece no país em 1964, os elementos básicos dessa concepção socioeducacional foram mantidos tecendo a política educacional, mas agregando agora um referencial a mais, que é aquele do valor técnico especializado da educação. Essa peculiaridade dará às políticas públicas do período e, em particular, às políticas educacionais um feitio explicitamente tecnicista sob uma perspectiva ideológica tecnocrática. Foi característica do movimento conduzido pela elite empresarial e pelo estamento militar a idéia-força de que o desenvolvimento tecnológico é a grande matriz de todo desenvolvimento econômico, desde que possa ocorrer num clima de total harmonia político-social. Daí ser a educação chamada a implementar uma vocação eminentemente dedicada à formação profissional, visando à preparação de mão-de-obra técnica bem qualificada de cidadãos ordeiros e pacíficos. Foi imbuído desse espírito que o próprio mote do novo sistema de gerenciamento da nação se expressou, retomando o anacrônico lema comtiano 'ordem e progresso', que então passou a ser 'desenvolvimento e segurança'. Politicamente, o regime levou aos estertores as últimas veleidades do discurso liberal populista, sufocando, inclusive pela repressão violenta, todas as iniciativas atreladas ao ideário libertário do período anterior, pondo fim ao populismo sob todas as suas expressões. Ao mesmo tempo, o atrelamento da economia nacional ao capitalismo internacional se consolidou definitivamente, mediante uma política de associação e de dependência. A função do Estado nacional se redefine, gerando um Executivo forte e centralizador, com poder de controle político-policial, modernizando e centralizando a administração pública e repelindo brutalmente toda contestação. Trata-se de um regime tecnoburocrático, assumidamente autoritário e repressor. 
Valores proclamados, seja pela ideologia católica, seja pela ideologia liberal, são reenquadrados nas coordenadas da ideologia tecnocrática, que passa a ser o critério de sua validade e sobrevivência no novo contexto social. Suas contribuições só são aproveitadas quando não se contrapõem aos novos interesses, não provocando interferências e questionamentos nos negócios de Estado da nova ordem político-social. Ao mesmo tempo, o governo militar apoiava, incentivava e induzia iniciativas, em todos os campos da vida social, que concretizassem os valores de sua nova política plenamente em sintonia com o capitalismo. Assim, no campo educacional e cultural, favoreceu e incentivou a privatização, uma vez que a educação deve ser entendida e praticada como um serviço, no seio de um mercado livre. A demanda por educação, tão cara às camadas médias da população, deverá ser atendida pela oferta do mercado dos serviços educacionais. Trata-se de uma política de expansão pela privatização. Ademais, o Estado pós-64 tem uma visão instrumentalista da educação, organizada em função do crescimento econômico (Martins, 1981). O conteúdo do ensino deve ser técnico, sem conotação política de cunho crítico. Visa-se à maior produtividade possível, a baixo custo, mediante o preparo de uma mão-deobra numerosa, com qualificação puramente técnica, disciplinada e dócil, adequada ao atendimento das necessidades do sistema econômico. A ideologia tecnocrática do período pratica um autoritarismo disciplinar intrínseco ao processo de engenharia social que deve comandar todos os aspectos da vida da sociedade. Alicerçada epistemologicamente no mesmo cientificismo positivista, que se julga legitimado pela sua eficácia tecnológica, opera a modernização da sociedade pelo uso da sofisticação técnico-informacional, ao mesmo tempo que, investindo pesado nos meios de comunicação, desenvolve um intenso programa de indústria cultural destinado à formação da opinião pública, banalizando ainda mais os conteúdos do conhecimento disponibilizado para as massas.

Após 25 anos de autoritarismo exacerbado, o regime, no início da década de 1980, começa a dar sinais de exaustão. Devorando seus próprios filhos, não mais satisfazia aos interesses capitalistas que pretendiam se universalizar mundo afora. Considerou-se superada essa fase da imposição tecnocrática, entendendo-se que os 25 anos foram suficientes para aplainar o terreno para uma nova etapa, agora não mais baseada na repressão violenta pela força, mas pela impregnação sutil da subjetivação ideológica por si mesma. Nos últimos trinta anos, o país vivencia então uma nova fase marcada pela implementação da agenda neoliberal, nova proposta do capitalismo internacional. 


\section{Os Desafios da Educação no Contexto da Sociabilidade Neoliberal}

A partir dos anos 1980, o Brasil, como de resto todo o Terceiro Mundo, é instado a inserir-se no novo processo de desenvolvimento econômico e social do capitalismo em expansão. De preferência isso deveria ser feito sem o uso da violência física de regimes repressivos. Ao contrário, deveria acontecer num ambiente político-social de redemocratização. Nessa linha, os grandes agentes desse capitalismo internacional sem pátria especificam, além de cobrar, via mecanismos propriamente econômicos, a adoção de suas práticas produtivas, monetárias e financeiras, comprometendo todos os países por meio de acordos mundiais, passando a exigir também adequações nos campos político e cultural. A meta continua sendo aquela da plena expansão do capitalismo, agora sem concorrências ideológicas significativas e numa perspectiva declarada de globalização. Fala-se então da agenda neoliberal, ou seja, de uma retomada dos princípios do liberalismo clássico, mas com a devida correção de seus desvios humanitários. O que está em pauta é a total liberação das forças do mercado, a quem cabe a efetiva condução da vida das nações e das pessoas. Daí a pregação do livre-comércio, da estabilização macroeconômica e das reformas estruturais necessárias, em todos os países, para que o sistema tenha alcance mundial e possa funcionar adequadamente. Opera-se então severa crítica ao Estado do Bem-Estar Social, propondo-se um estado mínimo, em seu papel e funções. A iniciativa política deve dar prioridade à iniciativa econômica dos agentes privados. Graças às impressionantes inovações tecnológicas, mormente na esfera da informática, mudam-se igualmente as relações industriais, o sistema do trabalho e o gerenciamento da produção. Os mercados financeiros são liberados e expandidos. Os Estados nacionais tornam-se reféns das políticas internacionais do grande capital. A política interna dos países, por sua vez, é forçada a esse ajuste econômico, impondo a queda dos salários reais, o crescimento do desemprego estrutural, a estatização da dívida externa e a elevação da taxa de juros. Isso implica também a ruptura do esquema de financiamento do setor público (Ianni, 2004; Lombardi, Saviani \& Sanfelice, 2004).

Assim como nas fases anteriores, também agora desencadeia-se um processo ideológico para justificar o modelo imposto, apresentando-o como o único capaz de realizar os objetivos emancipatórios da sociedade e, nesse sentido, superando os anteriores. Mais uma vez, tem-se um conjunto articulado de 
valores que são proclamados, mas não realizados. Uma retórica, que não deixa de encontrar apoios estratégicos em formulações teóricas do pensamento pósmoderno, se torna insistentemente presente em todas as frentes do debate social, fazendo sua cerrada defesa. Ao mesmo tempo, por meio da legislação e das medidas programáticas, o governo passa a aplicar políticas públicas que vão efetivando as diretrizes neoliberais, mais uma vez adiando e talvez inviabilizando uma educação que possa ser mediação da libertação, da emancipação e da construção da cidadania. Não sem razão, o ceticismo e a desesperança constituem a conclusão de estudiosos da questão educacional brasileira. Ao falar da escola brasileira, em conclusão a seus estudos históricos sobre a educação escolar, conclui Xavier (2005:291):

Ela parece ser uma instituição, se não dispensável, secundária para o funcionamento da sociedade brasileira, tal como se encontra estruturada. Entretanto, é fundamental, para o controle das insatisfações populares e a neutralização dos movimentos sociais contestatórios e reivindicatórios, alimentar a crença no caráter redentor da educação escolarizada. Daí a ênfase no discurso pedagógico, nos debates e na elaboração de projetos educacionais e a falta de pressa em realizá-los.

Para essa autora, ocorre uma mitificação da escola, mitificação que atua como um dos pilares da doutrina liberal produzida na transição capitalista e que penetrou cedo em nossa sociedade como parte da ideologia do colonialismo. E quanto mais o capitalismo avançou no país, mais se solidificou essa crença. $\mathrm{O}$ poder se concentrava, a riqueza crescia e supostamente não se distribuía porque a expansão da escola não acompanhava o crescimento populacional, ou sua qualidade não atendia às demandas sociais. "A escola não revoluciona ou transforma a sociedade que a produz e à qual serve; ela apenas consolida e maximiza as transformações em curso quando a aparelhamos para tanto" (Xavier, 2005:284).

Essa forma atual de expressão histórica do capitalismo, sob predomínio do capital financeiro, conduzido de acordo com as regras de um neoliberalismo desenfreado, num momento histórico marcado por um irreversível processo de globalização econômica e cultural, produz um cenário existencial em que as referências ético-políticas perdem sua força na orientação do comportamento das pessoas, trazendo descrédito e desqualificação para a educação. Ao mesmo tempo que, pelas regras da condução da vida econômica e social, instaura um quadro de grande injustiça social, sonegando para a maioria das pessoas as 
condições objetivas mínimas para uma subsistência num patamar básico de qualidade de vida, interfere profundamente na constituição da subjetividade, no processo de subjetivação, manipulando e desestabilizando valores e critérios. Prevalece um espírito de niilismo axiológico, de esvaziamento de todos os valores, de fim das utopias e metanarrativas e da esperança de um futuro melhor, de incapacidade de construir projetos. A eficiência e a produtividade são os únicos critérios válidos. Com bem sintetiza Goergen, "generaliza-se nesse processo para toda a cultura um aspecto da ordem econômica: a eficiência tornase padrão do bom comportamento exigido pela sociedade" (Lombardi \& Goergen, 2005:3).

Configura-se então uma sociabilidade típica desse contexto neoliberal, que se constitui atrelada a profundas mudanças provocadas pelas injunções dessa etapa da economia capitalista na esfera do trabalho, da cidadania e da cultura. Desse modo, constata-se a ocorrência de situações de degradação, no mundo técnico e produtivo do trabalho; de opressão, na esfera da vida social; e de alienação, no universo cultural. Essas condições manifestam-se, em que pesem as alegações em contrário de variados discursos, como profundamente adversas à formação humana, o que tem levado a um crescente descrédito quanto ao papel e à relevância da educação, como processo intencional e sistemático.

Nesse contexto da história real, a educação é interpelada pela dura determinação dessa realidade, no que diz respeito às condições objetivas da existência. Numa profunda inserção histórico-social, a educação é serva da história. Aqui se paga tributo a nossa condição existencial de seres encarnados e, como tais, profundamente predeterminados - esfera dos a priori existenciais. Uma lógica perversa compromete o esforço da humanização. São adversas as condições para se assegurar a qualidade necessária para a educação. Em que pese a existência, nas esferas do Estado brasileiro, de um discurso muito elogioso e favorável à educação, a prática real da sociedade política e das forças econômicas desse atual estágio histórico não corresponde ao conteúdo de seu discurso. Esse discurso se pauta em princípios e valores elevados, mas que não são sustentados nas condições objetivas para sua realização histórica no plano da realidade social.

No plano da subjetividade, utilizando-se de diferentes modalidades de intervenções ideológicas, particularmente através dos meios de comunicação, o sistema atua fortemente no processo da subjetivação humana. Numa frente, opera a subversão do desejo, deturpando a significação do prazer, não se inves- 
tindo adequadamente no aprimoramento da sensibilidade estética. Açulam-se os corpos no sentido de fazer deles fogueiras insaciáveis de prazer que jamais será satisfeito. Ocorre total regressão do estético. Embora prometa a felicidade, não gera condições para sua efetiva realização por todas as pessoas. Subverte também a vontade, impedindo o exercício de sua liberdade, não deixando que o homem pratique sua condição de igualdade: não investe na formação do cidadão, ou seja, aquele que pode agir livremente na sociedade de iguais. Propaga a idéia de uma democracia puramente formal. Não tem por meta o cidadão, mas o contribuinte, o socícola, aquele que habita o locus social mas não compartilha efetivamente de sua constituição, não compartilha das decisões que instauram o processo político-social. No fundo mantém-se a servidão... que até se torna voluntária... Toda essa pedagogia, em vez de levar os sujeitos a entenderse no mundo, mistifica o mundo, manipulando-o para produzir a ilusão da felicidade. Prosperidade prometida mas nunca realizada. Leva ao individualismo egoísta e narcísico, simulacro do sujeito autônomo e livre.

Essa pedagogia subverte ainda a prática do conhecimento, eliminando o seu processamento como construção dos objetos que são conhecidos. Torna-se mero produto e não mais processo, experiência de criatividade, de criticidade e de competência. É literalmente tecnicizado, objetivado, empacotado. A própria ciência é vista como conhecimento eminentemente técnico, o que vem a ser um conceito autocontraditório. Todas as demais formas de saber são desqualificadas. O ceticismo e o relativismo generalizados se impõem, sob alegação de seus compromissos com metanarrativas infundadas.

Nesse contexto, prospera uma ética hedonista baseada no individualismo, de traço narcísico, que vê o homem como se fosse um átomo solto, vivendo em torno de si mesmo, numa sensibilidade ligada apenas ao espetáculo. Puro culto ao prazer que se pretende alcançar pelo consumo compulsivo e desregrado dos bens do mercado. Essa lógica fundada na exacerbada valorização de uma suposta autonomia e suficiência do sujeito individual, no apelo ao consumo desenfreado, compromete o reconhecimento e a reafirmação dos valores universais da igualdade, da justiça e da eqüidade, referências necessárias para uma concepção mais consistente da humanidade, alicerçada no valor básico da dignidade humana.

Coagida pela pressão das determinações objetivas, de um lado, e pelas interferências subjetivas, de outro, a educação é presa fácil do enviesamento ideológico, que manipula as intenções e obscurece os caminhos, confundindo 
objetivos com interesses. Tal situação aumenta e agrava o desafio que a educação enfrenta em sua dialética tarefa de, simultânea e contraditoriamente, inserir os sujeitos educandos nas malhas culturais de sua sociedade e de levá-los a criticar e a superar essa inserção; assim como de fazer um investimento na conformação das pessoas a sua cultura ao mesmo tempo que precisa levá-las a se tornarem agentes da transformação dessa cultura.

Como a educação tem papel fundamental no processo de subjetivação, embora não seja ela o único vetor desse processo, já que essa subjetivação se dá também por outras vias, seja no âmbito da vivência familiar, seja pelos meios de comunicação de massa, seja ainda por interações informais das pessoas no seio da sociedade civil, ela sofre o impacto dessas forças geradas no bojo da dinâmica da vida social e cultural do capitalismo contemporâneo.

\section{O Horizonte do COMPROMISSO ÉTICO-PolítICO DA}

\section{EDUCAÇÃO: EM BUSCA DE UMA NOVA SOCIABILIDADE}

No contraponto dessa situação de degradação, de opressão e de alienação, a educação é interpelada pela utopia, ou seja, por um télos que acena para uma responsabilidade histórica de construção de uma nova sociedade também mediante a construção de uma nova sociabilidade. Isso decorre da condição dos homens como sendo também seres teleológicos, dispondo da necessidade e da capacidade de estabelecer fins para sua ação. É isso que ocorre com a educação; ela precisa ter intencionalidades, buscar a realização de fins previamente estabelecidos.

Levando em conta o seu papel no processo de subjetivação e tendo em vista que o conhecimento é a única ferramenta que cabe ao educador utilizar para enfrentar esses desafios, há que se entender a educação como processo que faz a mediação entre os seus resultados e as práticas reais, pelas quais os brasileiros devem conduzir sua história. Assim, cabe à educação ter em seu horizonte três objetivos intrínsecos:

1) Desenvolver ao máximo o conhecimento científico e tecnológico em todos os campos e dimensões; superar o amadorismo e apropriar-se da ciência e da tecnologia disponíveis para alicerçar o trabalho de intervenção na realidade natural e social. 
2) Desenvolver ao máximo a sensibilidade ética e estética buscando delinear o télos da educação com sensibilidade profunda à condição humana; sentir a razão de ser da existência e a pulsação da vida.

3) Desenvolver ao máximo sua racionalidade filosófica numa dupla direção: numa frente, esclarecer epistemicamente o sentido da existência, e, noutra, afastar o ofuscamento ideológico dos vários discursos; construir uma contra-ideologia como ideologia universalizante que apresenta os produtos do conhecimento para atender aos interesses da totalidade dos homens.

Pela sua própria natureza, a educação tende a atuar como força de conformação social, mas precisa atuar também como força de transformação social. A conformação nasce da necessidade de conservação da memória cultural da espécie, força centrípeta, apelo da imanência, enquanto que a transformação, força centrífuga, apelo da transcendência, busca um avanço, a criação do novo, gerando elementos que respondam pela criação de nova cultura.

A educação conforma os indivíduos, inserindo-os na sua sociedade, fazendo-os compartilhar dos costumes morais e de todos os demais padrões culturais, com o fito de preservar a memória cultural; porém, ao transformar, impele à criação de nova cultura, reavaliando seus estágios anteriores de subjetivação. Cabe-lhe questionar os estágios vigentes de uma perspectiva crítica, desconstruindo para reconstruir, pois o que não se transforma se petrifica.

É pela mediação de sua consciência subjetiva que o homem pode intencionar sua prática, pois essa consciência é capaz de elaborar sentidos e de se sensibilizar a valores. Assim, ao agir, o homem está sempre se referenciando a conceitos e valores, de tal modo que todos os aspectos da realidade envolvidos com sua experiência, todas as situações que vive e todas as relações que estabelece são atravessados por um coeficiente de atribuição de significados, por um sentido, por uma intencionalidade, feita de uma referência simultaneamente conceitual e valorativa. Desse modo, as coisas e situações relacionam-se com nossos interesses e necessidades, por meio da experiência dessa subjetividade valorativa, atendendo, de um modo ou de outro, a uma sensibilidade que temos, tão arraigada quanto aquela que nos permite representar as coisas e conhecêlas mediante os conceitos.

Com efeito, a ética só pode ser estabelecida por meio de um processo permanente de decifração do sentido da existência humana, tal como ela se 
desdobra no tecido social e no tempo histórico, não mais partindo de um quadro atemporal de valores, abstratamente concebidos e idealizados. Essa investigação é inteiramente compromissada com as mediações históricas da existência humana, não tendo mais a ver apenas com ideais abstratos, mas também com referências econômicas, políticas, sociais, culturais. Nenhuma ação que provoque a degradação do homem em suas relações com a natureza, que reforce sua opressão pelas relações sociais, ou que consolide a alienação subjetiva, pode ser considerada moralmente boa, válida e legítima.

É por isso que, na perspectiva do modo atual de se conceber a ética, ela se encontra profundamente entrelaçada com a política, concebida esta como a área de apreensão e aplicação dos valores que atravessam as relações sociais que interligam os indivíduos entre si. Mas a política, por sua vez, está intimamente vinculada à ética, pelo fato de não poder se ater exclusivamente a critérios técnico-funcionais, caso em que se transformaria numa nova forma de determinismo extrínseco ao homem, à sua humanidade. Isso quer dizer que os valores pessoais não são apenas valores individuais; eles são simultaneamente valores sociais, pois a pessoa só é especificamente um ser humano quando sua existência realiza-se nos dois registros valorativos. Assim, a avaliação ética de uma ação não se refere apenas a uma valoração individual do sujeito; é preciso referi-la igualmente ao índice do coletivo.

É assim que, à luz das contribuições mais críticas da filosofia da educação da atualidade, impõe-se atribuir à educação, como sua tarefa essencial, a construção da cidadania. A educação já se deu outrora como objetivo a busca da perfeição humana, idealizada como realização da essência do homem, de sua natureza; mais recentemente, essa perfeição foi concebida como plenitude da vida orgânica, como saúde física e mental. Hoje, no entanto, as finalidades perseguidas pela educação dizem respeito à instauração e à consolidação da condição de cidadania, pensada como qualidade específica da existência concreta dos homens, lembrando-se sempre que essa é uma teleologia historicamente situada.

Com efeito, a educação só se compreende e se legitima enquanto for uma das formas de mediação das mediações existenciais da vida humana, se for efetivo investimento em busca das condições do trabalho, da sociabilidade e da cultura simbólica. Portanto, só se legitima como mediação para a construção da cidadania. Por isso, enquanto investe, do lado do sujeito pessoal, na construção dessa condição de cidadania, do lado dos sujeitos sociais estará investindo na 
construção da democracia, que é a qualidade da sociedade que assegura a todos os seus integrantes a efetivação coletiva dessas mediações.

À educação cabe, como prática intencionalizada, investir nas forças emancipatórias dessas mediações, num procedimento contínuo e simultâneo de denúncia, desmascaramento e superação de sua inércia de entropia, bem como de anúncio e instauração de formas solidárias de ação histórica, buscando contribuir, com base em sua própria especificidade, para a construção de uma humanidade renovada. Ela deve ser assumida como prática simultaneamente técnica e política, atravessada por uma intencionalidade teórica, fecundada pela significação simbólica, mediando a integração dos sujeitos educandos nesse tríplice universo das mediações existenciais: no universo do trabalho, da produção material, das relações econômicas; no universo das mediações institucionais da vida social, lugar das relações políticas, esfera do poder; no universo da cultura simbólica, lugar da experiência da identidade subjetiva, esfera das relações intencionais. Em suma, a educação só se legitima intencionalizando a prática histórica dos homens...

Com efeito, se se espera que a educação seja de fato um processo de humanização, é preciso que ela se torne mediação que viabilize, que invista na implementação dessas mediações mais básicas, contribuindo para que elas se efetivem em suas condições objetivas reais. Ora, esse processo não é automático, não é decorrência mecânica da vida da espécie. É verdade que ao superar a transitividade do instinto e, com ela, a univocidade das respostas às situações, a espécie humana ganha em flexibilidade, mas simultaneamente torna-se vítima fácil das forças alienantes, uma vez que todas as mediações são ambivalentes: ao mesmo tempo que constituem o lugar da personalização, constituem igualmente o lugar da desumanização, da despersonalização. Assim, a vida individual, a vida em sociedade, o trabalho, as formas culturais, as vivências subjetivas, podem estar levando não a uma forma mais adequada de existência, da perspectiva humana, mas antes a formas de despersonalização individual e coletiva, ao império da alienação. Sempre é bom não perdermos de vista a idéia de que o trabalho pode degradar o homem, a vida social pode oprimi-lo e a cultura pode aliená-lo, ideologizando-o...

É por isso que, ao lado do investimento na transmissão aos educandos dos conhecimentos científicos e técnicos, impõe-se garantir que a educação seja mediação da percepção das relações situacionais, que ela lhes possibilite a apreensão das intrincadas redes políticas da realidade social, pois só a partir daí eles 
poderão se dar conta também do significado de suas atividades técnicas e culturais. Cabe ainda à educação, no plano da intencionalidade da consciência, desvendar os mascaramentos ideológicos de sua própria atividade, evitando assim que ela se instaure como mera força de reprodução social e se torne força de transformação da sociedade, contribuindo para extirpar do tecido desta todos os focos da alienação (Althusser, s.d.; Gramsci, 1968; Severino, 1986).

A análise crítica da experiência histórica da educação brasileira mostra que ela desempenhou, em cada um dos seus cenários temporais, a função de reprodução da ideologia, mediante o que contribuiu para a reprodução das relações sociais vigentes a cada momento. Mas isso não compromete seu outro papel fundamental, que é aquele de transformar essas relações sociais, contribuindo para a elaboração de uma contra-ideologia que possa identificar-se com os interesses e objetivos da maioria da população, fazendo com que os benefícios do conhecimento possam atingir o universo da comunidade humana a que se destina.

Esse compromisso ético-político da educação para com a condução do destino da sociedade não pode, no entanto, ser concebido nos parâmetros da ética essencialista, de fundo metafísico, ou de uma ética funcionalista, de fundo fenomenista. Trata-se de entender sua concepção e prática com base num enfoque praxista. Isso decorre de um modo igualmente novo de pensar o homem. Embora continue sendo entendido como ser natural e dotado de uma identidade subjetiva, que lhe permite projetar e antever suas ações, ele não é visto mais nem como um ser totalmente determinado nem como um ser inteiramente livre. Ele é simultaneamente determinado e livre. Sua ação é sempre um compromisso, em equilíbrio instável entre as injunções impostas pela sua condição de ser natural e a autonomia de sujeito capaz de intencionalizar suas ações, a partir da atividade de sua consciência.

Por práxis, entende-se a prática real do homem, atravessada pela intencionalização subjetiva, ou seja, pela reflexão epistêmica elucidativa e esclarecedora, que delineia os fins e o sentido dessa ação.

O que está em pauta, pois, na reflexão filosófica contemporânea, é a radical historicidade humana. $\mathrm{O}$ homem concebido como ser histórico perde tanto sua fusão com a totalidade metafísica como com a natureza física do mundo. Desse ponto de vista, ele só é especificamente humano quando, em que pesem suas amarras ao mundo objetivo, é capaz de ir construindo-se efetivamente mediante sua ação real. Ora, a ética só tem a ver com sua dimensão especificamente humana, e é nessa especificidade que ela pode encontrar suas referências. 
Esse é o sentido da historicidade da existência humana, ou seja, o homem não é a mera expressão de uma essência metafísica predeterminada, nem o mero resultado de um processo de transformações naturais que estaria em evolução. Ao contrário, naquilo em que o faz especificamente humano, o homem é um ser em permanente processo de construção, em ininterrupto devir. Nunca está pronto e acabado, nem no plano individual, nem no plano coletivo, como espécie. Por sobre um lastro de uma natureza físico-biológica prévia, mas que é pré-humana, compartilhada com todos os demais seres vivos, ele vai se transformando e se reconstruindo como ser especificamente humano, como ser 'cultural'. E isso não apenas na linha de um necessário aprimoramento, de um aperfeiçoamento contínuo ou de progresso. Ao contrário, essas mudanças transformativas, decorrentes de sua prática, podem até ser regressivas, nem sempre sinalizando para uma eventual direção de aprimoramento de nosso modo de ser. O que é importante observar é que seu modo de ser vai se constituindo por aquilo que ele efetivamente faz; é sua ação que o constitui, e não seus desejos, seus pensamentos ou suas teorias...

Assim, a ética contemporânea entende que o sujeito humano se encontra sob as injunções de sua realidade natural e histórico-social, que até certo ponto o conduz, determinando seu comportamento, mas que é também constituída por ele, por meio de sua prática efetiva. Ele não é visto mais como um sujeito substancial, soberano e absolutamente livre, nem como um sujeito empírico puramente natural. Existe concretamente nos dois registros, na medida mesma em que é um sujeito histórico-social, um sujeito cultural. É uma entidade natural histórica, determinada pelas condições objetivas de sua existência, ao mesmo tempo que atua sobre elas por meio de sua práxis.

\section{A Necessidade do Espaço Público para um Projeto Educacional Comprometido com a Emancipação Humana: a escola pública e a CIDADANIA}

O ético-político incorpora a sensibilidade aos valores da convivência social, da condição coletiva das pessoas. A relação, a inter-relação, a dependência recíproca entre as pessoas, é também um valor ético - a eticidade que se apóia na dignidade humana. Essa dignidade não se referencia apenas à existência social, mas também à co-existência social. 
É a partir dessa exigência que se pode compreender a importância da escola para a construção da cidadania. Com efeito, para que a prática educativa real seja uma práxis, é preciso que ela se dê no âmbito de um projeto. A escola é o lugar institucional de um projeto educacional. Isso quer dizer que ela deve instaurar-se como espaço-tempo, como instância social que sirva de base mediadora e articuladora dos outros dois projetos que têm a ver com o agir humano: de um lado, o projeto político da sociedade e, de outro, os projetos pessoais dos sujeitos envolvidos na educação.

Todo projeto implica uma intencionalidade, assim como suas condições reais, objetivas, de concretização, já que a existência dos homens se dá sempre no duplo registro da objetividade/subjetividade, de modo que estão sempre lidando com uma objetividade subjetivada e com uma subjetividade objetivada.

Configura-se aqui a complexa e intrincada questão das relações do processo educativo com o processo social que o envolve por todos os lados. É o que vem sendo apresentado sob o enfoque da teoria do reprodutivismo da educação, segundo a qual a escola nada mais faria do que reproduzir as relações de dominação presentes no tecido social na medida em que, como instância que lida com os instrumentos simbólicos, reproduziria os valores hegemônicos da sociedade, inculcando-os nas novas gerações. A escola é vista então como privilegiado aparelho ideológico do Estado que, por sua vez, não é um representante dos interesses universais da sociedade, mas tão-somente de grupos privilegiados e, conseqüentemente, dominantes.

Reapresenta-se então a questão da dialética objetividade/subjetividade. Em se tratando de processo que lida fundamentalmente com ferramentas simbólicas, a educação é ambígua, ambivalente, uma vez que a subjetividade é lugar privilegiado de alienação. Trata-se ainda de múltiplas subjetividades envolvidas, o que potencializa a força da alienação em relação aos dados da objetividade circundante.

Com efeito, a prática da educação pressupõe mediações subjetivas, a intervenção da subjetividade de todos aqueles que se envolvem no processo. Dessa forma, tanto no plano de suas expressões teóricas como naquele de suas realizações práticas, a educação implica a própria subjetividade e suas produções. Mas a experiência subjetiva é também uma riquíssima experiência das ilusões, dos erros e do falseamento da realidade, ameaçando assim, constantemente, comprometer sua própria atividade. Não sem razão, pois, o exercício da prática educativa exige, da parte dos educadores, uma atenta e constante 
vigilância diante dos riscos da ideologização de sua atividade, seja ela desenvolvida na sala de aula, seja em qualquer outra instância do plano macrossocial do sistema de educação da sociedade.

O procedimento da consciência, no seu desempenho subjetivo, não tem a inflexibilidade mecânica e linear dos instintos. Ao representar e ao avaliar os diversos aspectos da realidade, a consciência facilmente os falseia. A representação simbólica da realidade, que lhe cabia fazer, perde então seu caráter objetivo e se impregna de significações que não mais correspondem à realidade, e a visão elaborada pelo sujeito fica falseada. $\mathrm{Na}$ sua atividade subjetiva, a consciência deveria visar e dirigir-se à realidade objetiva, atendo-se a ela. No entanto, quanto mais autônoma e livre em relação à transitividade dos instintos, mais frágil se torna em relação à objetividade e mais suscetível de sofrer interferências perturbadoras. À consciência subjetiva pode ocorrer de se projetar numa objetividade não-real, apenas projetada, imaginada, ideada. É como se estivesse imaginando um mundo inventado, invertido. E assim a consciência, alienandose em relação à realidade objetiva, constrói conteúdos representativos com os quais pretende explicar e avaliar os vários aspectos da realidade e que apresenta como sendo verdadeiros e válidos, aptos não só a explicá-los mas também a legitimá-los. Porém, alienada, a consciência não se dá conta de que tais conteúdos nem sempre estão se referindo adequadamente ao objeto. $\mathrm{Na}$ verdade, tais conteúdos - idéias, representações, conceitos, valores - são ideológicos, ou seja, têm obviamente um sentido, um significado, mas descolado do real objetivo, pois referem-se de fato a um outro aspecto da realidade que, no entanto, fica oculto e camuflado. Ocorre um falseamento da própria apreensão pela consciência, um desvirtuamento de seu proceder, decorrente sobretudo da pressão de interesses sociais que, intervindo na valoração da própria subjetividade, altera a relação de significação das representações.

Esses interesses/valores que intervêm e interferem na atividade cognoscitiva e valorativa da consciência nascem das relações sociais de poder, das relações políticas, que tecem a trama da sociedade. É para legitimar determinadas relações de poder que a consciência apresenta como objetivas, universais e necessárias, portanto supostamente verdadeiras, algumas representações que, na realidade social, referem-se de fato a interesses de grupos particulares, em geral grupos dominantes, detentores do poder no interior da sociedade.

A força do processo de ideologização é, sem dúvida, um dos maiores percalços da prática educativa, porque ela atua no seu âmago. Mas a possibilida- 
de da interferência da ideologia não invalida nem inviabiliza a escola. O simples fato do reconhecimento do poder ideologizador da educação testemunha igualmente o valor da subjetividade, seu poder de doação de significações. O que cabe, no entanto, à escola, na sua autoconstituição como centro de um projeto educacional, é ter presente essa ambivalência de sua própria condição de agência educativa e investir na explicitação e na crítica desses compromissos ideológicos, etapas preliminares para que possa tornar seu projeto elemento que transforma a escola em lugar também de elaboração de um discurso contra-ideológico e, conseqüentemente, de instauração de uma nova consciência social e até mesmo de novas relações sociais. A educação pode se tornar também uma força transformadora do social, atuando portanto contra-ideologicamente.

Educar contra-ideologicamente é utilizar, com a devida competência e criticidade, as ferramentas do conhecimento, as únicas de que efetivamente o homem dispõe para dar sentido às práticas mediadoras de sua existência real. Por mais ambíguos e fragilizados que sejam esses recursos da subjetividade, eles são instrumentos capazes de explicitar verdades históricas e de significar, com um mínimo de fidelidade, a realidade objetiva em que o homem desenvolve sua história. O que se impõe é a adequada exploração do conhecimento, poderosa estratégia do homem para se nortear no espaço social e no tempo histórico. Daí a relevância do conhecimento em suas dimensões científica e filosófica, âmbitos nos quais há a possibilidade efetiva de se assegurar a competência e a criticidade necessárias no caso de utilização de nossa subjetividade.

A escola se caracteriza, pois, como a institucionalização das mediações reais para que uma intencionalidade possa tornar-se efetiva, concreta, histórica, para que os objetivos intencionalizados não fiquem apenas no plano ideal, mas ganhem forma real.

Assim sendo, a escola se dá como lugar do entrecruzamento do projeto político coletivo da sociedade com os projetos pessoais e existenciais de educandos e educadores. É ela que viabiliza que as ações pedagógicas dos educadores se tornem educacionais, na medida em que se impregna das finalidades políticas da cidadania que interessa aos educandos. Se, de um lado, a sociedade precisa da ação dos educadores para a concretização de seus fins, de outro os educadores precisam do dimensionamento político do projeto social para que sua ação tenha real significado como mediação da humanização dos educandos. Estes encontram na escola um dos espaços privilegiados para a vivificação e a efetivação de seu projeto. 
A escola se faz necessária para abrigar e mediatizar o projeto educacional, imprescindível para uma sociedade autenticamente moderna. A especificidade do trabalho pedagógico exige uma institucionalização de meios que vinculem educadores e educandos. A escola não pode ser substituída pelos meios de comunicação de massa; toda relação pedagógica depende de um relacionamento humano direto. Toda situação de aprendizagem, para ser educacional, não basta ser tecnicamente operativa; precisa ser pedagógica, ou seja, relacionar pessoas diretamente entre si. Aliás, a fecundidade didática dos meios técnicos já é dependente da incorporação de significados valorativos pessoais.

Para que se possa falar de um projeto impregnado por uma intencionalidade significadora, impõe-se que todas as partes envolvidas na prática educativa de uma escola estejam profundamente integradas na constituição e no vivenciamento dessa intencionalidade. Do mesmo modo que, num campo magnético, todas as partículas do campo estão imantadas, no âmbito de um projeto educacional todas as pessoas envolvidas precisam compartilhar dessa intencionalidade, adequando seus objetivos parciais e particulares ao objetivo abrangente da proposta pedagógica decorrente do projeto educacional. Mas, para tanto, impõe-se que toda a comunidade escolar seja efetivamente envolvida na construção e na explicitação dessa mesma intencionalidade. É um sujeito coletivo que deve instaurá-la; e é nela que se lastreiam a significação e a legitimidade do trabalho em equipe e de toda interdisciplinaridade, tanto no campo teórico como no campo prático.

Ao investir na constituição da cidadania dos indivíduos, a educação escolar está articulando o projeto político da sociedade - que precisa ter seus membros como cidadãos - e os projetos pessoais desses indivíduos que, por sua vez, precisam do espaço social para existir humanamente.

Em sociedades históricas passando por momentos de determinação alienadora, de opressão e de exploração, implementando projeto político voltado para interesses egoísticos de grupos particulares hegemônicos, como é o caso de nossa sociedade brasileira atual, fica ainda mais fragilizada a força da instituição escolar nesse seu trabalho de construção da cidadania, uma vez que o projeto educacional autêntico estaria necessariamente em conflito com o projeto político da sociedade que, ao oprimir a maioria dos indivíduos que a integram, compromete até mesmo a possibilidade de o educador construir seu projeto pessoal. Esbarra-se aí nos limites impostos pela manipulação, pela ex- 
propriação e pela alienação dos seres humanos. Muitas vezes, investir na construção de um projeto educacional é pura prática de resistência.

No entanto, mesmo nesse caso, a escola se torna ainda mais necessária, impondo-se um investimento sistemático com vistas a sua sustentação e ao desenvolvimento de um projeto educacional eminentemente contra-ideológico, ou seja, desmascarando, denunciando, criticando esse projeto político, não se conformando com ele, não o aceitando passivamente. Com as armas fornecidas pelo conhecimento, devendo realizar seu trabalho educacional no contexto de uma sociedade opressiva, os educadores precisam pautar-se num público de educação, concebido e articulado em instituições que gerem um espaço público aberto à totalidade social, sem qualquer tipo de restrição.

Após duas décadas sob a tutela de um Estado autoritário e autocrático, no qual a dimensão pública se reduzira à expressão meramente tecnoburocrática do estatal, mergulhada na voracidade consumista do momento neoliberal, o sentido do público acaba deslizando para uma mera identificação do civil ao mercadológico, ou seja, a sociedade civil não é mais a comunidade dos cidadãos, mas a comunidade dos produtores e dos consumidores em relação de mercado. Toda a vida social passa a ser medida e marcada pelo compasso das transações comerciais, do que não escapa nenhum setor da cultura, nem mesmo a educação. O dilema que vivemos hoje se expressa exatamente por essa ambigüidade, pela qual a dimensão pública se esvazia, impondo a minimização do Estado na condução das políticas sociais, que ficam dependentes apenas das leis do mercado, tido como dinâmica própria da esfera do privado. Daí o ímpeto privatizante que varre a sociedade e a cultura do Brasil nas últimas três décadas, sob o sopro incessante e denso dos ventos ideológicos do neoliberalismo. A oferta de educação, assim como dos demais chamados serviços públicos, é um dentre outros empreendimentos econômico-financeiros a serem conduzidos nos termos das implacáveis leis do mercado.

Em todas as situações de ambigüidade que as atravessam, as categorias de público e de privado padecem de uma limitação congênita que compromete sua validade político-educacional, impondo aos atuais teóricos e práticos da educação uma inconclusa tarefa de redimensioná-los com vistas a assegurar-lhe eficácia e legitimidade. Para tanto, é preciso ter presente a historicidade da construção dessas categorias. Assim, é necessário reconhecer a procedência da universalidade do bem comum, mas que deve ser entendida como uma possibilidade histórica a ser realizada no fluxo do tempo. Impõe-se ainda reconhecer a 
rica contribuição do iluminismo liberal na construção do estado de direito como tentativa de instauração de uma determinada ordenação do social. Como se sabe, o direito nasceu na civilização humana como forma de organizar as relações entre os homens, de modo a garantir um mínimo de simetria nessas relações, assegurando assim a justiça, ou seja, que um mínimo de eqüidade nelas reinasse. No entanto, tão logo conseguiu apreender-se como uma coletividade a que se impunha uma convivência em comum, a humanidade percebeu, com base em sua experiência empírica, que o tecido social não se constituía como uma teia de membros iguais. O tecido social era todo marcado por forte hierarquização estratificada, em que ocorre grande desequilíbrio das forças em presença, em que alguns indivíduos ou grupos não só se opunham uns aos outros como dominavam os indivíduos ou grupos mais fracos. Uma intensa luta de interesses colocava esses elementos em situação de conflito, geradora de muitas formas de violência e de opressão.

É íntima a aproximação que os teóricos modernos fizeram entre democracia e o caráter público da atuação do Estado (por isso mesmo, deveria ser preferencialmente uma res publica), mediante a qual poderia assegurar a todos os integrantes da sociedade o acesso e o usufruto dos bens humanos, garantindo a todos, com o máximo de eqüidade, o compartilhamento do bem comum. No entanto, essa expectativa tende a frustrar-se continuamente, tal a fragilidade do direito em nossa sociedade. A experiência histórica da sociedade brasileira foi e continua sendo marcada pela realidade brutal da violência, do autoritarismo, da dominação, da injustiça, da discriminação, da exclusão, enfim, da falta do direito. É assim que o nosso não tem sido um Estado de direito; ele sempre foi, sob as mais variadas formas, um Estado de fato, no qual as decisões são tomadas e implementadas sob o império da força e da dominação. Não é um agenciador dos interesses coletivos e muito menos dos interesses dos segmentos mais fracos da população que constitui sua sociedade civil. Na verdade, as relações de poder no interior da sociedade brasileira continuam moldadas nas relações de tipo escravocrático que a fundaram, aquelas relações do tipo 'casa-grande e senzala', metáfora que é, na verdade, descrição científica.

Desse modo, o direito acaba desvirtuado pelo seu próprio enviesamento ideológico. Se, de um lado, ele é visto pelos que dele dependem como meio para contar com o usufruto do bem comum, de outro ele é usado por aqueles que dele pouco precisam para salvaguardar seus privilégios. No campo específico da educação, a legislação passa a ser então estratagema ideológico, prome- 
tendo exatamente aquilo que não pretende conceder. Por isso mesmo, na medida em que grupos com interesses diferentes e opostos podem lutar por eles, acabam travando uma luta ideológica, ou seja, buscam servir-se da legislação como um instrumento da garantia desses direitos. Nessa luta sem tréguas, o caráter público da educação vai sendo, cada vez mais, comprometido.

É por isso mesmo que, de acordo com o atual modelo, o processo fundamental da história humana deve ser conduzido pelas forças da própria sociedade civil, e não mais pela administração via aparelho do Estado. Entendese que o motor da vida social é o mercado, e não a administração política. As leis gerais são aquelas da economia do mercado, e não as da economia política. E o mercado se regula por forças concorrenciais, nascidas dos interesses dos indivíduos e grupos, que se 'vetorizam' no interior da própria sociedade civil donde a proposta do Estado mínimo e os elogios à fecundidade da livreiniciativa, à privatização generalizada etc.

Dessa situação decorrem igualmente os profundos equívocos que vêm atravessando a política educacional brasileira das últimas décadas, ao estender a privatização exacerbada e sem critérios também aos assim chamados 'serviços educacionais', atendendo apenas às diretrizes da agenda econômica neoliberal. Trata-se de prática duplamente perversa. De um lado, desconhece a incapacidade econômica da maioria da população brasileira de se integrar no processo produtivo de uma economia de mercado, que pressupõe um patamar mínimo de condições objetivas para que os agentes possam dela participar. Abaixo desse nível, essa participação se situará necessariamente numa esfera de marginalidade econômico-social. De outro lado, a perversidade do sistema se manifesta igualmente no fato da precária qualidade de educação que sobra para a população que dela mais precisa, tanto nas escolas/empresas quanto nas escolas públicas ainda mantidas pelo Estado, ou seja, tal educação ofertada não habilitará essa população a ponto de lhe viabilizar a ruptura do círculo de ferro de sua opressão. Apenas uma elite vinculada aos segmentos dominantes dispõe de uma educação qualificada, sem dúvida alguma capaz de habilitá-a para continuar no exercício da dominação.

O sentido do público é aquele abrangido pelo sentido do bem comum efetivamente universal, ou seja, que garanta ao universo dos sujeitos o direito de usufruir dos bens culturais da educação, sem nenhuma restrição. A questão básica não é a da referência jurídica de manutenção dos subsistemas de ensino, mas a do seu efetivo envolvimento com o objetivo da educação universalizada. 
As instituições particulares de ensino também não podem eximir-se de um comprometimento que leve em conta um projeto político-social identificado com as necessidades objetivas do todo da população. O equívoco radical está em se entenderem e, sobretudo, em se vivenciarem apenas como instâncias do mercado, em que os bens simbólicos da cultura transformam-se em bens puramente econômicos, esvaziados de todo conteúdo humano e humanizador.

\section{CONSIDERAÇÕES FINAIS}

De todas essas considerações, impõe-se concluir que, na atual situação histórico-social brasileira, só mesmo um sistema universalizado de ensino estará em condições de enfrentar o desafio da construção da cidadania universalização esta absolutamente imprescindível para tanto. Se é verdade que possam existir, hipoteticamente, variadas modalidades de mediações da educação, historicamente é também verdadeiro que a escola se revela como sua mediação potencialmente mais eficaz para a universalização da educação. Isso implica, sem nenhuma dúvida, a constituição de um grande e qualificado sistema público de ensino.

A identidade específica da prática educativa, a ser implementada por todos aqueles que têm um projeto civilizatório para o enfrentamento dos desafios históricos lançados na atualidade, se encontra no tripé formado pelo domínio do saber teórico, pela apropriação da habilitação técnica e pela sensibilidade ao caráter político das relações sociais. Mas essas três dimensões só se consolidam se soldadas, se articuladas pela dimensão ética. O envolvimento pessoal e a sensibilidade ética dos educadores estão radicalmente vinculados a um compromisso com o destino dos homens. É à humanidade que cada um tem que prestar contas. Por isso mesmo é que o maior compromisso ético é ter compromisso com as responsabilidades técnicas e com o engajamento político. Trata-se, pois, para todos os homens, de vincular sua responsabilidade ética à responsabilidade referencial de construção de uma sociedade mais justa, mais eqüitativa - vale dizer, uma sociedade democrática, constituída de cidadãos participantes em condições que garantam a todos os bens naturais, os bens sociais e os bens simbólicos, disponíveis para a sociedade concreta em que vivem, e a que todos têm direito, em decorrência da dignidade humana de cada um.

O respeito e a sensibilidade ao eminente valor representado pela dignidade da pessoa humana não tornam essa postura ética abstrata, idealizada e aliena- 
da. Ao contrário, exigem o aguçamento da sensibilidade às condições históricas e concretas de nossa existência - afinal, suas únicas mediações reais. Esse aguçamento exige, por sua vez, o pleno compromisso de aplicação do uso da única ferramenta para a orientação da existência humana: o conhecimento que precisa tornar-se, então, competente, criativo e crítico. A mais radical exigência ética que se faz manifesta, neste quadrante de nossa história, para todos os sujeitos envolvidos na e pela educação é, sem nenhuma dúvida, o compromisso de aplicação do conhecimento na construção da cidadania.

\section{REFERÊNCIAS BIBLIOGRÁfICAS}

ALTHUSSER, L. Ideologia e Aparelhos Ideológicos de Estado. Lisboa, São Paulo: Presença, Martins Fontes, s.d.

BRESSER PEREIRA, L. C. Desenvolvimento e Crise no Brasil: 1939-1967. Rio de Janeiro: Zahar, 1968.

FERNANDES, F. A Revolução Burguesa no Brasil: ensaio de interpretação sociológica. Rio de Janeiro: Zahar, 1975.

GRAMSCI, A. A Concep̧ção Dialética da História. Rio de Janeiro: Civilização Brasileira, 1968

IANNI, O. O cidadão do mundo. In: LOMBARDI, J. C.; SAVIANI, D. \& SANFELICE, J. L. (Orgs.). Capitalismo, Trabalho e Educação. 2.ed. Campinas: Autores Associados, 2004. p.27-34.

IBGE. PNAD: Relatório 2004. Brasília: IBGE, 2005.

LOMBARDI, J. C. \& GOERGEN, P. (Orgs.). Ética e Educação: reflexões filosóficas e históricas. Campinas: Autores Associados, 2005.

LOMBARDI, J. C.; SAVIANI, D. \& SANFELICE, J. L. (Orgs.). Capitalismo, Trabalho e Educação. 2.ed. Campinas: Autores Associados, 2004.

MARTINS, C. B. Ensino Privado, um Retrato sem Retoques. São Paulo: Global, 1981.

SEVERINO, A. J. Educação, Ideologia e Contra-Ideologia. São Paulo: EPU, 1986.

SEVERINO, A. J. Educação, Sujeito e História. São Paulo: Olho d'Água, 2001.

XAVIER, M. E. S. P. Políticas educacionais, modelos pedagógicos e movimentos sociais. In: MIGUEL, M. E. B. \& CORRÊA, L. T. (Orgs.). A Educação Escolar em Perspectiva Histórica. Campinas: Autores Associados, Capes, 2005. p.283291. (Memória da educação) 


$$
\begin{gathered}
\text { Formato: } 16 \times 23 \mathrm{~cm} \\
\text { Tipologia: Garamond e Engravers } \\
\text { Papel: Pólen Bold } 90 \mathrm{~g} / \mathrm{m}^{2}(\text { miolo) } \\
\text { Cartão supremo } 250 \mathrm{~g} / \mathrm{m}^{2} \text { (capa) } \\
\text { Fotolito: Graftipo Gráfica e Editora Ltda.(capa) } \\
\text { Fotolitos: Laser vegetal (miolo) } \\
\text { Reimpressão e acabamento: Editora e Papéis Nova Aliança } \\
\text { Rio de Janeiro, julho de } 2014
\end{gathered}
$$

Não encontrando nossos títulos em livrarias, contactar a EDITORA Fiocruz: Av. Brasil, 4036 - Térreo - sala 112 - Manguinhos - 21040-361

Rio de Janeiro - RJ.

Tel.: (21) 3882-9039 e 3882-9041 - Telefax: (21) 3882-9006 www.fiocruz.br/editora editora@fiocruz.br 